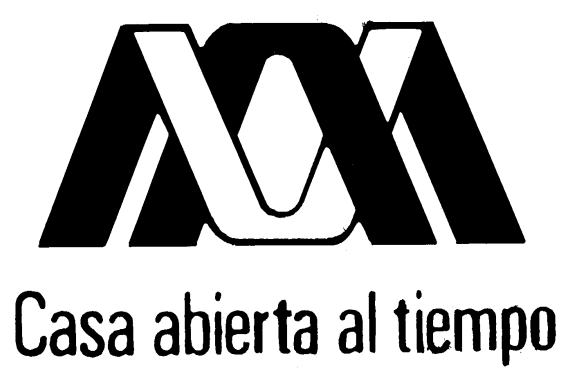

UNIVERSIDAD AUTÓNOMA METROPOLITANA

UNIDAD IZTAPALAPA

DIVISIÓN DE CIENCIAS SOCIALES Y HUMANIDADES

POSGRADO EN CIENCIAS ANTROPOLÓGICAS

\title{
Las reivindicaciones del Pueblo Maya: \\ Etnicidad y poder en Yucatán
}

\author{
RodRigo AlEJANDRo LLANES SALAZAR
}

Tesis de Doctorado en Ciencias Antropológicas

Director: Dr. Rodrigo Díaz Cruz

Asesores: Dra. Ella Fanny Quintal Avilés

Dr. Luis Bernardo Reygadas Robles Gil

México, D.F.

Enero, 2016 


\section{AGRADECIMIENTOS}

Es un lugar común decir que toda investigación, aunque sea de autoría individual, en realidad es resultado de un trabajo colectivo. Lo cierto es que los lugares comunes, precisamente por serlo, también son un buen punto de encuentro y de partida. Así que comienzo esta tesis agradeciendo a todos aquellos que, de una $\mathrm{u}$ otra forma, hicieron posible la realización de esta investigación.

Agradezco al Dr. Rodrigo Díaz Cruz, director de esta tesis, por haber cobijado mi proyecto de investigación hace ya más de seis años y por su valioso acompañamiento durante todo este tiempo en el desarrollo de esta pesquisa.

Agradezco a los integrantes del Comité de esta tesis, el Dr. Luis Reygadas y la Dra. Ella Fanny Quintal, así como a dos lectores anónimos, cuyos comentarios críticos ayudaron a mejorar este trabajo.

Agradezco a todos mis profesores y compañeros en el Doctorado en Ciencias Antropológicas de la Universidad Autónoma Metropolitana-Iztapalapa. Especial mención merecen Socorro Flores y Nancy Flores por su atento apoyo.

Agradezco al Consejo Nacional de Ciencia y Tecnología por otorgarme una beca para llevar a cabo mis estudios de doctorado.

Agradezco al Dr. Esteban Krotz por todas sus enseñanzas.

Muchas de las ideas aquí desarrolladas se presentaron en diversos espacios, por lo que agradezco a todos aquellos que leyeron, escucharon, criticaron y discutieron los argumentos aquí planteados.

Agradezco al Dr. Stefan Rinke, del Instituto de Estudios Latinoamericanos de la Universidad Libre de Berlín, por su tutoría durante mi estancia de investigación en dicha institución durante la primera mitad de 2014, en donde pude presentar y discutir avances del capítulo IV de la tesis. 
Agradezco a la Dra. Ana Paula de Teresa, al Dr. Ricardo Pérez Monfort y al Dr. Jean Loup Amselle por invitarme a participar en el Seminario internacional "Representaciones y estereotipos culturales en actividades turísticas y de desarrollo en América Latina”, para presentar y discutir avances de esta tesis, particularmente del capítulo V. Agradezco también a todos los participantes de dicho seminario por sus aportaciones. Ana Paula y Ricardo merecen otro agradecimiento por su cálida hospitalidad, la cual me permitió finalizar la redacción de esta tesis en la Ciudad de México.

Agradezco a la Dra. Eugenia Iturriaga por la lectura de esta tesis y por invitarme a participar en una mesa coordinada por ella en el marco de la "Tercera conferencia sobre etnicidad, raza y pueblos indígenas en América y el Caribe" de la Latin American \& Caribbean Ethnic Studies (LACES). En este congreso presenté como ponencia avances del capítulo $\mathrm{V}$ de la tesis, la cual ganó el premio a mejor ponencia de estudiante de posgrado otorgado por LACES. También le agradezco su invitación a participar en el grupo de trabajo "Pueblos indígenas y racismo" de la Red Integra del Consejo Nacional de Ciencia y Tecnología, en el que presenté avances de mi tesis.

Agradezco a la Dra. Gabriela Vargas y al Dr. Igor Ayora por invitarme a exponer avances de mi investigación, particularmente del capítulo VI, en el "Coloquio Internacional Ciencia, Tecnología, Estética y Poder”, y a publicarlos en un libro editado por ellos.

Agradezco a la Dra. Shannan Mattiace, con quien discutí particularmente el capítulo IV de esta tesis, parte del cual fue publicado en un artículo con su coautoría.

Agradezco de manera muy especial a todas las personas que colaboraron en esta investigación regalándome un poco de su tiempo y compartiendo conmigo sus proyectos para la construcción de una sociedad intercultural más justa. A ellos dedico esta tesis con la esperanza de contribuir a la construcción de dicha sociedad.

Por último, agradezco a mis amigos y familia por todo su apoyo durante todos estos años. Fueron firmes soportes en los episodios de mayor flaqueza y compañeros entrañables para los momentos de goce y alegría. Agradezco especialmente a mi hermana Erika y a mi mamá Ileana, así como a mi esposa Romina, quien me acompañó desde las formulaciones iniciales de las ideas de esta tesis, su desarrollo, corrección y 
reformulación. Le agradezco también a Romina su atenta y paciente lectura de las diferentes versiones de esta tesis.

Cierro estos agradecimientos con otro lugar común para iniciar la tesis: a pesar de toda la valiosa ayuda, de sabios consejos e inteligentes críticas recibidas, asumo la responsabilidad de todas las palabras escritas que vienen a continuación. 


\section{ÍNDICE}

Introducción 1

PRIMERA PARTE.

PODER Y ETNICIDAD: DISCUSIÓN TEÓRICA

I. Poder y etnicidad: discusión teórica

SEGUNDA PARTE.

LA MAYANIZACIÓN DE LOS MESTIZOS YUCATECOS: EMERGENCIA DE LA ETNICIDAD MAYA EN YUCATÁN

II. Continuidades y discontinuidades entre mayas antiguos y contemporáneos.

La disociación entre mayas y mestizos

III. La mayanización de los mestizos yucatecos:

la problemática étnica en Yucatán

96

TERCERA PARTE.

\section{LAS REIVINDICACIONES DEL PUEBLO MAYA: CAMPOS, ARENAS Y PROCESOS}

IV. Las reivindicaciones legales: la "Ley para la protección de los derechos de la comunidad maya del estado de Yucatán" 
V. Cha'anil Kaaj: la etnicidad como performance y la celebración de una "performance étnica"

VI. La emergencia de jóvenes mayas: la literatura y las nuevas tecnologías como arenas de reivindicación étnica

Conclusiones

Bibliografía 


\section{INTRODUCCIÓN}

\section{Planteamiento del problema}

Dos años antes de la caída del Muro de Berlín — del "fin de la historia", en el sentido del fin de las alternativas al capitalismo_-, el antropólogo mexicano Guillermo Bonfil (1987) publicó su célebre obra, México profundo: una civilización negada, en la que planteó que los grupos indígenas en México, así como quienes comparten su matriz cultural, representan una alternativa al modelo civilizatorio en crisis del "México imaginario". Pocos años después, en enero de 1994, el levantamiento del Ejército Zapatista de Liberación Nacional (EZLN), así como los proyectos autonómicos asociados con él en Chiapas, contribuyeron de manera significativa a la idea de que las poblaciones indígenas, particularmente los movimientos y los distintos proyectos de reivindicación étnica, representan una verdadera alternativa a las sociedades industriales y postindustriales, marcadas por una creciente desigualdad social y un deterioro ambiental en aumento (ver Piketty 2014; Klein 2015). Ante la crisis no sólo económica y civilizatoria, sino también de inseguridad y violencia, la utopía indígena o étnica se proyecta en la actualidad en Cherán y las autodefensas en Michoacán (ver Gil Olmos 2014); en las policías comunitarias de Guerrero (Sierra 2013) así como en el espíritu comunitario de las escuelas normales rurales (Coll 2015); en las juntas de buen gobierno zapatista y en su "escuelita", su festival y sus seminarios o "semilleros"; en la lucha del pueblo yaqui así como la de muchos otros movimientos en contra de las grandes obras de infraestructura en el país. Algunas de estas organizaciones y movimientos tienen como referente los recientes procesos de transformación constitucional en Bolivia y Ecuador, en donde se ha 
reconocido el "Buen Vivir" como una "alternativa al desarrollo" (Gudynas y Acosta 2011); así como el Foro Social Mundial. ${ }^{1}$

Si bien para muchos los movimientos indígenas y las reivindicaciones étnicas representan una utopía o una alternativa al proyectar imágenes de una sociedad más igualitaria, regida por la cooperación —el muul meyaj, dicen los mayas- y no por la competencia, por la horizontalidad y no por la jerarquía, así como por una relación armónica con el medio ambiente - recordemos el título de uno de los libros emblemáticos sobre el tema, Utopía y revolución, de Guillermo Bonfil (1981)—, algunos estudiosos han puesto en entredicho tales utopías. Por un lado, se ha observado cómo las políticas indigenistas contemporáneas que aceptan y promueven la multiculturalidad coinciden con políticas neoliberales que tienen efectos más bien negativos para las poblaciones indígenas - a contrapelo del título del libro de Bonfil, considérese el nombre de la obra de Luis Vázquez (2010), Multitud y distopía. Al respecto, el historiador francés Henri Favre (1998) ha argumentado que la "gestión étnica" se corresponde con el Estado neoliberal, mientras que el antropólogo norteamericano Charles R. Hale (2002) ha propuesto el concepto de "multiculturalismo neoliberal" para referirse a cómo el Estado acepta ciertas demandas indígenas de carácter "cultural" (como las referentes a la lengua), mientras que rechaza otras más radicales y de carácter material (como las tierras y otros recursos naturales). Por otra parte, algunos estudiosos han advertido que en los movimientos indígenas y reivindicaciones étnicas los principales beneficiarios son las elites indígenas, cuyas demandas de reconocimiento cultural aún no han logrado beneficiar a las poblaciones indígenas de base (ver Vázquez León 2010). También encontramos posiciones claramente detractoras de las demandas de autonomía indígena y de legislaciones en materia de derechos indígenas, bajo el argumento de que tales

\footnotetext{
${ }^{1}$ Para algunos analistas (Escobar 2010; Santos 2009), el Foro Social Mundial, con su lema "Otro mundo es posible”, representa una globalización contrahegemónica a la globalización neoliberal hegemónica. Al respecto, el reconocido sociólogo portugués Boaventura de Sousa Santos (2009:180) ha escrito "Y entre los movimientos que han sido partícipes en el Foro Social Mundial, los movimientos indígenas son, bajo mi punto de vista, aquellos cuyas concepciones y prácticas representan la más convincente emergencia de pensamiento postabismal. Este hecho es el más propicio para la posibilidad de un pensamiento postabismal, siendo que las poblaciones indígenas son los habitantes paradigmáticos del otro lado de la línea, el campo histórico del paradigma de la apropiación y la violencia". Por "pensamiento postabismal", Santos (2009:181) se refiere a la idea de que "la diversidad del mundo es inagotable y que esa diversidad todavía carece de una adecuada epistemología". Del mismo modo, en el sitio electrónico Beautiful Solutions, proyecto vinculado con el reciente libro de Naomi Klein (2015) Esto lo cambia todo, aparecen el Buen vivir, la comunalidad y la escuelita zapatista como "bellas soluciones" al problema ambiental.
} 
acciones contribuirían al mantenimiento de usos y costumbres que violan derechos humanos y que las autonomías constituyen un peligro de balcanización de los estadosnación (ver Bartra 1997). De igual modo hallamos visiones críticas en torno a los discursos de los pueblos “indígenas” u “originarios”. Así, Immanuel Wallerstein (2015) nos advierte del peligro de que "Los 'indígenas' han tendido a utilizar una retórica de pureza cultural, que ellos consideran que es profanada o está amenazada por otros que son marginales o de nuevo arribo a la región, y que como tal tienen menos derechos que los grupos indígenas". Wallerstein concluye con la sentencia de que "Todos somos migrantes. Nadie de nosotros somos indígenas a menos que suprimamos la realidad histórica". ${ }^{2}$ Por último, a propósito del reciente conflicto de Crimea, el cual en no pocas ocasiones ha sido interpretado en términos étnicos y del que se ha dicho que ha cambiado al mundo contemporáneo, el periodista polaco Maciek Wisniewski (2015) ha observado que "la hasta hace poco inimaginable insistencia en el origen étnico de los 'verdaderos liberadores de Auschwitz' -los ucranios (jsic!)- revela un importante cambio en la ideología del capitalismo tardío: las comunidades ya no se mueven según las divisiones políticas/clasistas, sino por pasiones étnicas/'identitarias"”. ¿Cómo entender las diferencias de interpretación con respecto a los movimientos indígenas, la etnicidad y reivindicaciones étnicas contemporáneos?, ¿cómo explicar que, mientras que algunos encuentren en las poblaciones indígenas utopías, otros vean en ellas distopías?, ¿en qué sentido la etnicidad y las reivindicaciones étnicas representan alternativas para un mundo mejor?

En esta tesis abordaré las cuestiones arriba planteadas a partir del estudio de un caso particular: el de la etnicidad maya en Yucatán. Inmediatamente debo advertir que el tema ha provocado perplejidades y polémicas entre los estudiosos: a pesar de que Yucatán es el segundo estado con mayor población hablante de una lengua indígena en México, ${ }^{3}$ no existe en él un movimiento indígena comparable al EZLN en Chiapas, a las

\footnotetext{
${ }^{2}$ Hay que advertir que el propio Wallerstein (2015) distingue que 'Los reclamos de los grupos 'indígenas' en pos de mantener sus patrones culturales y sus valores colectivos tienen una tonalidad bastante diferente en el caso de ser una resistencia a la inmigración de grupos que están al fondo de una escala social que cuando se trata de personas que se sitúan en la cúspide de esa escala". Esta distinción produce un dilema: “¿Podemos, en efecto, respaldar la inevitable y deseable forma de un multiculturalismo que sea la base de un intercambio pacífico de valores culturales? ¿O sucumbiremos a las limpiezas étnicas xenofóbicas por todo el mundo?".

${ }^{3}$ Se trata predominantemente de una sola lengua, la maya, y en esto Yucatán se distingue de Oaxaca, el
} 
manifestaciones de comunalidad en Oaxaca (ver Díaz 2007), o a otros movimientos indígenas y reivindicaciones étnicas en otros estados de la república. Aún más, si bien los académicos locales hablan frecuentemente de la existencia del "Pueblo Maya", del "grupo étnico maya", de la "etnicidad maya" o, simplemente, de "los mayas" en Yucatán, en años más recientes, antropólogos e historiadores, casi todos ellos extranjeros, han negado la existencia de una etnicidad maya en Yucatán (ver la discusión en Cocom y Castañeda 2004; Gabbert 2004; Lizama 2007; Restall 1997). ¿Cómo explicar estas diferencias interpretativas?, ¿existe o no una etnicidad maya en Yucatán?, si es así, ¿cómo es?, ¿puede entenderse como una utopía, como una alternativa a un orden social hegemónico o acaso se asemeja más a las distopías étnicas advertidas por algunos especialistas?

\section{Objetivos}

El objetivo de esta investigación es estudiar la emergencia de la etnicidad maya en Yucatán. Como podrá advertirse, este objetivo ha sido planteado a partir de una serie de presupuestos e hipótesis que se someterán a discusión en la investigación. El primero de ellos es que existe la etnicidad maya en Yucatán y que, como todo fenómeno sociocultural e histórico, lejos de ser "natural", ha emergido en determinadas condiciones. ¿En qué consiste esta etnicidad?, ¿cómo ha sido el proceso de su emergencia? Otro presupuesto es que la etnicidad maya en Yucatán no es un fenómeno compartido por todos los maya hablantes del estado, por lo que cabe preguntar, ¿quiénes son los actores protagonistas de esta etnicidad? Un presupuesto más es que podemos entender la emergencia de la etnicidad maya a partir del análisis del fenómeno del poder y que este análisis resulta clave para entender en qué medida la etnicidad maya representa una utopía, una alternativa para una vida mejor para los maya hablantes del estado y en qué medida es un fenómeno con alcances aún limitados.

A partir de este objetivo central, el presente trabajo plantea una serie de objetivos particulares, todos ellos relacionados con los presupuestos e interrogantes arriba

estado con mayor número de hablantes de lengua indígena en el país. Como veremos más adelante, según datos del Censo de Población y Vivienda de 2010, de un total de 1, 955, 577 habitantes en Yucatán, 537, 618 (el 28\%) hablan maya. Para la Comisión Nacional para el Desarrollo de los Pueblos Indígenas, de un total de 1, 818, 948 habitantes de Yucatán, 966, 787 (53.14\%) son considerados mayas, y de un total de 106 municipios, 98 son considerados indígenas (40\% y más de población indígena). 
planteados: 1) contribuir a la discusión en torno a la relación entre etnicidad y poder, ¿cómo entender teórica y etnográficamente la relación entre dichos fenómenos?; 2) Contribuir al análisis de las reivindicaciones étnicas en México y América Latina, particularmente en un contexto en el que, tras la crisis del "socialismo realmente existente", los movimientos indígenas y los proyectos de reivindicación étnica se plantean como nuevas utopías, como referentes de "Otro mundo es posible"; 3) aportar al conocimiento de la población maya hablante de Yucatán, particularmente al fenómeno de la etnicidad maya; 4) conocer el proceso etnopolítico de reivindicación del "Pueblo Maya"; 5) conocer cuáles son los principales campos, arenas y procesos en los que han tenido lugar las reivindicaciones étnicas del "Pueblo Maya" y quiénes han sido sus principales actores y cuáles sus demandas centrales.

\section{Precisiones de términos, orden de la exposición y cuestiones metodológicas}

En el proceso de emergencia de etnicidad maya en Yucatán una idea clave es la de la existencia del "Pueblo Maya", cuyo origen se remonta a tiempos prehispánicos y del cual se consideran herederos los actuales mayas (ver Anderson 2007; Gellner 2008; Sand 2011). Sin embargo, como es el caso de muchas naciones y pueblos, la idea del "Pueblo Maya" es una relativamente reciente, que se remonta a finales del siglo XIX e inicios del $\mathrm{XX}$, y que sólo en las últimas décadas del siglo XX ha sido apropiada por maya hablantes como un elemento de identidad y movilización étnica.

"Llama la atención —advirtió Luis Vázquez (2010:263) — nuestra total ausencia en el debate antropológico internacional sobre el concepto de 'pueblo indígena' y de sus referentes indexales, contextuales, o meramente adaptativos con los que se ha transplantado en México", así que valga una primera precisión sobre el término "Pueblo". En su sentido étnico, como observa el etnólogo alemán Mark Münzel (2007:328), el vocablo es una traducción de la palabra alemana Volk. El movimiento de la "contraIlustración" - reconstruido lúcidamente por el historiador de las ideas Isaiah Berlin (2006) - hizo del concepto de "Pueblo" una de sus piedras angulares. De este modo, Johann Herder, originario de Prusia, en su ambicioso proyecto de escribir una historia universal de la humanidad, interpretó "el lenguaje y el folklore de cada pueblo como la 
expresión de su espíritu interno inconsciente, su Volkgeist característico" (Wolf 2001:47).

En este contexto de auge del nacionalismo a finales del siglo XVIII y principios del XIX, “el término 'pueblo' — escribe el historiador israelí Shlomo Sand (2011:39) [fue utilizado] para acentuar la antigüedad y continuidad de la nacionalidad que buscaba construir”. "El pueblo — continúa Sand (2011:40) — se convirtió en un puente entre el pasado y el presente". Después de ser sustituido por algunos otros términos como "raza" y "etnia", en el siglo XX "su principal atractivo se encontraba en su armonización de un bagaje cultural con los lazos de sangre, de un pasado lingüístico con un origen biológico; en otras palabras, en su combinación de un producto histórico con un hecho que exige respeto como fenómeno natural" (Sand 2011:40). De este modo, el término "Pueblo" destaca la unidad entre un grupo - especialmente si éste comparte una lengua—, su continuidad en el tiempo y su diferencia con otros colectivos.

Cabe apuntar que el término "Pueblo" comparte un aire de familia con conceptos como "cultura" y "etnia". Como aprecia Eric Wolf (2001), el concepto antropológico de "cultura" proviene de este sentido romántico y nacionalista de "Pueblo", volk o volkgeist. Por su parte, Münzel (2007:328) ha documentado que, en América Latina, "la palabra 'etnia' es usada prácticamente como un sinónimo moderno, y políticamente menos escandaloso, de la palabra Volk (el pueblo de la patria, en un sentido a veces poético, a veces político). Por lo tanto, un 'ethnos' es algo similar a lo que era el Volk en el pensamiento romántico".

De esta forma, cuando hago referencia al "Pueblo Maya" aludo a una categoría que es reivindicada por una serie de actores políticos que enfatiza la unidad entre "los mayas", su continuidad con los mayas prehispánicos y su diferencia con otros grupos. Existe en Yucatán un discurso que enfatiza la existencia del "Pueblo Maya" y no del "grupo maya" o "etnia maya" (incluso algunos entrevistados y personas con quienes hablaba me corregían cuando yo empleaba un término distinto al de "Pueblo Maya"). Es un discurso que tiene que ver tanto con la tradición romántica y nacionalista en torno a la idea del Volk y Volkgeist, como con el más reciente discurso jurídico en torno a los derechos de los pueblos. 
Debo aclarar en este punto que al sostener que el "Pueblo Maya" es una "invención" no niego la existencia de miles de personas maya hablantes en el estado; mucho menos que, al ser una invención, sea una idea ilegítima que deba ser erradicada. El Pueblo Maya es una invención tanto como lo es el "pueblo mexicano", el "pueblo francés" o el "pueblo judío" (Sand 2011). Me interesa cómo se ha construido la idea del Pueblo Maya y cómo pasa a ser una idea movilizadora entre ciertos actores. Parafraseando al antropólogo francés Jean-Loup Amselle (2010:27), no se trata de mostrar que no existe el Pueblo Maya, sino que las categorías con las que se piensan los actores sociales son productos históricos. Y, como ha escrito Amselle (2010:27), "al mostrar que no era posible asignar un sentido único a cualquier etnónimo que se tomara como ejemplo, queríamos subrayar la relatividad de la pertenencia étnica sin por ello negar a los individuos su derecho a reivindicar la identidad de su elección". "Que los grupos sociales se construyan [o se inventen] — continúa Amselle (2010:33) — lejos de ser una prueba de su artificialidad, refuerza su existencia”. A la historicidad de estas categorías e ideas, en la que viajeros, arqueólogos, antropólogos, escritores, entre otros intelectuales, han contribuido a gestar, así como las apropiaciones (Amselle 2010:34) de los actores mayas de dichas categorías, dedico un capítulo.

Esta tesis está dividida en tres partes. La primera, integrada por el capítulo I, está dedicada a la discusión teórica sobre la relación entre poder y etnicidad. En esta primera parte presento la revisión de algunas de las principales corrientes de análisis sobre poder en las ciencias sociales y argumento que el fenómeno de emergencia de la etnicidad maya, así como de las reivindicaciones del Pueblo Maya, deben ser entendidos en relación con el fenómeno del poder. Este capítulo puede ser leído en diálogo crítico con algunas de las principales corrientes analíticas sobre la etnicidad asociadas con el poscolonialismo, el giro decolonial, el programa de modernidad-colonialidad y los estudios sobre "indigeneidad". La tesis central de este capítulo es que podemos entender el poder como un fenómeno de dos dimensiones: por un lado, el control de recursos significativos $\mathrm{y}$, por otro, como órdenes clasificatorios simbólicos que se vuelven hegemónicos. Así, el análisis de la etnicidad y de las reivindicaciones étnicas debe hacerse en relación con esas dos dimensiones del poder. 
La segunda parte de esta tesis está integrada por dos capítulos. En el primero, "Continuidades y discontinuidades entre mayas antiguos y contemporáneos. La disociación entre mayas y mestizos”, exploro cómo en Yucatán la población maya hablante, convencionalmente considerada como "mestiza", no necesariamente se identifica como "maya". En este capítulo reviso una serie de discursos sobre los mayas para analizar después cómo éstos son retomados por actores étnicos que reivindican al Pueblo Maya. El segundo capítulo de esta sección, "La mayanización de los mestizos yucatecos: la problemática étnica en Yucatán”, está dedicada al análisis del surgimiento de una serie de actores que se identifican como mayas así como de las condiciones de emergencia de dichos actores.

La tercera parte de la tesis, "Las reivindicaciones del Pueblo Maya. Campos, arenas y procesos", está conformada por tres capítulos en los que analizo tres casos en donde los actores mayas presentan una serie de reivindicaciones: el campo jurídico, el campo festivo y los jóvenes involucrados en arenas tecnológicas y literarias. En términos metodológicos, debo aclarar que el objeto de mi investigación no es una comunidad o un grupo particular. Más bien, retomando la tradición procesualista en antropología, el objeto de análisis consiste en una serie de procesos, campos y arenas políticas que pueden englobarse en lo que aquí denomino las "reivindicaciones del Pueblo Maya". Desde luego, para poder analizar procesos, campos y arenas, la antropología observa situaciones sociales únicas e irrepetibles; dialoga, a veces de manera formal, otras de modo informal, con personas de carne y hueso igualmente singulares; también echa mano del análisis de documentos de diversa índole, desde periódicos, libros, artículos, documentos en archivos y, cada vez más, materiales provenientes de medios de comunicación y de Internet.

Es importante enfatizar que los procesos, campos y arenas son construcciones intelectuales del investigador, lo que no quiere decir que el fenómeno estudiado sea pura invención y ficción. Se tratan de construcciones intelectuales en tanto que son elaboradas por el investigador a partir de referentes epistemológicos, teóricos y metodológicos que no coinciden cabalmente con la realidad empírica, pero que sirven para entenderla (ver Bourdieu, Chamboredon y Passeron 2000; Weber 2006). En este orden de ideas, los procesos, campos y arenas aquí analizados son también una construcción intelectual y tienen un carácter "multilocal" (Marcus 2001), es decir, se manifiestan empíricamente en 
diversas localidades. Para aclarar esta cuestión, ¿cómo fue el proceso metodológico de esta tesis?

La mayor parte de la investigación de campo para esta tesis se realizó en la ciudad de Mérida, capital del estado de Yucatán. La razón original fue la siguiente: al inicio de la investigación me interesaba analizar el campo jurídico, en el cual se han planteado diversas reivindicaciones en torno a los derechos del Pueblo Maya, y en el cual ha tenido lugar un proceso político particular: el proceso de legislación en torno a dichos derechos (ver Krotz 2015a). Las consultas y sesiones legislativas tuvieron lugar en varias localidades de la ciudad, como el Congreso del Estado, las oficinas del Instituto para el Desarrollo de la Cultura Maya del Estado de Yucatán (Indemaya), la delegación estatal de la Comisión Nacional para el Desarrollo de los Pueblos Indígenas (CDI), la Universidad Autónoma de Yucatán (UADY), el Instituto Nacional de Antropología e Historia (INAH), entre otras instituciones. Mérida resultaba estratégica para observar las situaciones sociales relativas a ese proceso y campo y también para realizar entrevistas a actores claves en el tema. Esta parte de la investigación se materializó en el capítulo IV de la tesis, "Las reivindicaciones legales: la 'Ley para la protección de los derechos de la comunidad maya del estado de Yucatán"”.

Sin embargo, el trabajo de campo se extendió en términos temáticos. Cuando realizaba entrevistas a actores que habían participado en el proceso de la ley o tenían otros proyectos o acciones de reivindicaciones del Pueblo Maya, siempre les preguntaba al final con quién más me recomendarían hablar sobre el tema (el llamado "muestreo de bola de nieve"). En varias ocasiones me sugirieron hablar con jóvenes mayas y, cuando una de ellas me planteó sus acciones en términos de una "segunda generación" de sujetos mayas que reivindican a su pueblo, reparé en la problemática generacional y me interesé en los jóvenes mayas en cuanto jóvenes mayas, es decir, en cuanto una categoría social, cultural e histórica reciente, y en algunas de las arenas, como la de la literatura y las tecnologías de información y comunicación, como ámbitos políticos de sus reivindicaciones. Este trabajo se concretizó en el capítulo VI de la tesis, "La emergencia de jóvenes mayas: la literatura y las nuevas tecnologías como arenas de reivindicación étnica". 
Hacia el verano de 2013, uno de los jóvenes a los que había entrevistado meses atrás lanzó una convocatoria en Facebook para realizar un festival alternativo al Festival Internacional de la Cultura Maya que organizaba el Gobierno del Estado de Yucatán, pues consideraba que este último sólo usaba el nombre "maya" con fines políticos y mercantiles y que no daba cabida a la verdadera cultura maya. Su convocatoria tuvo una inmediata respuesta y en octubre de ese mismo año se celebró el Cha'anil Kaaj, "Festival Independiente de la Cultura Maya", organizado por un colectivo que surgió específicamente para el festival, Yóol Kaaj. A varios de los integrantes del colectivo los conocí previamente durante mi investigación y participé en el proceso mismo de organización del festival así como en la celebración del mismo. La investigación participativa de todo este proceso tuvo como resultado el capítulo V de la tesis, "Cha'anil Kaaj: la etnicidad como performance y la celebración de una "performance étnica"'. A pesar de que la observación de y participación en el festival ocurrió después de las entrevistas a jóvenes y el análisis de sus diversas acciones de reivindicación étnica, el hecho de que el festival retomara el discurso de los derechos de los pueblos indígenas como uno de sus fundamentos fue la razón por la cual este capítulo está ordenado inmediatamente después del relativo a la ley: como se verá más adelante, si bien la ley aprobada fue considerada fallida por varios sujetos y organizaciones, el discurso de los derechos del Pueblo Maya siguió expresándose en otros ámbitos, como el del festival o como en el de los proyectos y acciones de los jóvenes mayas.

Así, las reivindicaciones del Pueblo Maya de Yucatán son analizadas concretamente a partir de una serie de fenómenos: el campo jurídico y el proceso de la ley (o, en términos de Sally Moore [1978], de la ley como proceso); un campo que podríamos denominar "festivo" y que tuvo como proceso la realización de una serie de performances agrupadas en el festival Cha'anil Kaaj; así como en el campo de la literatura y de las nuevas tecnologías de información y comunicación, donde han tenido lugar arenas políticas específicas de reivindicaciones étnicas. Una de las primeras conclusiones que se obtienen del análisis de estos tres ámbitos es que, en una dimensión del poder, la relativa a los órdenes clasificatorios simbólicos de la sociedad, las reivindicaciones del Pueblo Maya han tenido logros notables, pues, a contrapelo del discurso gubernamental y mercantil en torno a la cultura maya, que la ubica 
principalmente en el pasado, han construido un discurso en torno al Pueblo Maya como algo vivo en el presente, que, a través de sus diversas prácticas y saberes, pueden contribuir a una sociedad intercultural mejor que la actualmente existente. Sin embargo, en términos de la otra dimensión del poder, la del control de recursos significativos, son ciertos actores los que se han beneficiado principalmente de estas reivindicaciones y la mayoría de la población maya hablante del estado continúa en condiciones de pobreza y marginación - aunque, desde luego, no es culpa de los actores beneficiados de las reivindicaciones del Pueblo Maya la condición de pobreza y marginación de la mayoría de los maya hablantes. En las conclusiones de la tesis se abordan con más detalle la comparación entre los tres ámbitos analizados y las argumentaciones planteadas a partir de ellos.

Antes de pasar a la discusión teórica, presentaré algunos datos y un estado de la cuestión sobre el problema de la etnicidad en Yucatán que servirán al lector para ubicarse en la problemática abordada en esta investigación.

De acuerdo con ciertos criterios, la población maya de Yucatán alcanza alrededor de la mitad de la población total del estado. El censo de 2010 del Instituto Nacional de Estadística y Geografía (Inegi) nos informa que la población hablante de una lengua indígena (HLI) en Yucatán es de un total de 544, 927 individuos, de los cuales 537, 618 —esto es, el abrumador 98\% — hablan la lengua maya peninsular. ${ }^{4}$ Estos hablantes de una lengua indígena representan el $30.3 \%$ de la población total del Estado de Yucatán. Cabe observar que este $30.3 \%$ es considerablemente menor al 37.3\% del año 2000 (549, 532 HLI) y se encuentra aún más lejano del 44.2\% de la situación de 1990 (525, 264 HLI), año en el que por primera vez se registra que la población hablante de la lengua maya representa menos de la mitad de la población yucateca (Ramírez Carrillo 2015:53). El censo de 2010 tiene la peculiaridad de que junto a la tendencia de disminución relativa de la población HLI en Yucatán en las últimas décadas, es la primera vez que se documenta una disminución en términos absolutos: de 549,532 maya hablantes que había en 2000 a los ya mencionados 537, 618 de 2010. Este proceso de disminución relativa y absoluta de hablantes de lengua maya ha llevado a algunos especialistas a plantear que la sociedad maya es "un mundo que desaparece" (Bracamonte, Lizama y Solís 2011). No se

\footnotetext{
${ }^{4}$ Las otras lenguas indígenas habladas por los habitantes de Yucatán con Ch’ol, Chontal, Tzeltal y Náhuatl.
} 
trata de un asunto menor y, cómo veremos más adelante, constituye una de las principales preocupaciones de los actores que reivindican al Pueblo Maya.

No obstante, otros conteos, que toman en cuenta criterios extra-lingüísticos fundamentalmente el de la autoadscripción-, nos revelan otro panorama. Por ejemplo, para inicios de la década pasada, la CDI estimaba que el 59.2\% de la población de Yucatán era indígena (Krotz 2004a). Del mismo modo, de acuerdo con el ya citado censo del Inegi del año 2010, la mayoría de la población del estado, el 62.7\% (esto es, 1, 850, 441 individuos), se definía como indígena. Contrario a la tendencia en el ámbito lingüístico, esta cifra es superior a la del año 2000, en el que el 58.96\% (equivalente a 977, 731 individuos) de la población del estado se definió como indígena. Nos encontramos entonces con un proceso de aumento de la autoadscripción indígena tanto en términos relativos como absolutos. Un proceso que podríamos caracterizar como de mayanización de la población, que será analizado más adelante.

¿En qué condiciones viven los mayas yucatecos? Sin duda, resulta difícil generalizar al respecto, pero como ha documentado Luis Ramírez Carrillo (2015:12, 31) en un estudio reciente, "en el sureste [de México], al igual que en otras regiones del país, la pobreza continúa vinculada a la identidad étnica y en particular a la población de origen maya [... por lo que] el polémico vínculo entre ser pobre y mantener la identidad étnica originaria es de hecho, desde mi punto de vista, uno de los procesos más urgentes por comprender". Ciertamente, ser maya en Yucatán no es sinónimo de ser pobre; de ello nos da cuenta Ricardo López Santillán (2011) en su investigación sobre mayas de clase media. No obstante, a través de diversos estudios, como el ya citado de Ramírez, se puede apreciar que gran parte de la población maya del estado vive en condiciones de pobreza.

De acuerdo con los resultados de la Encuesta sobe marginalidad, pobreza e identidad del pueblo maya (EMPIMAYA) realizada por el Centro de Investigaciones y Estudios Superiores en Antropología Social (CIESAS), los jefes de familia encuestados presentan una "dramática baja escolaridad": el 25.2\% no posee ninguna escolaridad, el $47.1 \%$ tiene la primaria incompleta y el 14.7\% logró concluirla (Bracamonte y Lizama 2006:42). En términos laborales, el 42.2\% de los jefes de familia se dedica a actividades propias del sector primario de la economía (principalmente a la agricultura milpera), el 
$24.2 \%$ al sector secundario y el $33.4 \%$ a labores del sector terciario. Pero entre sectores más jóvenes (población de 15 años y más) se advierte una terciarización laboral: el 29.9\% se dedica a labores del sector primario, el $29.2 \%$ al secundario y el $40.8 \%$ al terciario (Bracamonte y Lizama 2006:48). Como han advertido Pedro Bracamonte y Jesús Lizama (2006:49):

en este sector el mayor índice se concentra en los servicios generales [comerciales, de transporte, turísticos, entre otros] ( $12.2 \%$ de la población laboral de 15 años y más) y le siguen los servicios domésticos $(9.1 \%)$, el comercio al menudeo $(8.9 \%)$ y los servicios técnicos. Autoempleo, trabajo informal, bajos salarios y eventualidad son algunas de las características asociadas a ese tipo de actividades laborales.

En cuestión de salarios la situación no es más favorable, pues un $28.3 \%$ de los jefes de familia encuestados no reportó ingresos en la semana anterior a la encuesta, un $11.6 \%$ obtuvo el equivalente a medio salario mínimo, un $24.3 \%$ se ubicó en un rango entre medio y un salario mínimo, mientras que el $26.4 \%$ alcanzó entre uno y dos salarios mínimos (Bracamonte y Lizama 2006:50).

Por otra parte, como ha observado Bracamonte (2007), la población indígena de Yucatán también padece de una grave carencia de servicios. Nada más el 32.1\% de las viviendas que se encuestaron dispone de agua entubada en el interior de la vivienda y el 7.1\% de las viviendas mayas carece de servicio de electricidad (Bracamonte 2007:280). Las condiciones de salud tampoco son muy favorables, pues se registró un elevado índice de afecciones a las vías respiratorias (38.1\%) y de enfermedades gastrointestinales (19.3\%). En palabras de Bracamonte (2007:287), "la pobreza, que incluye una alimentación insuficiente, el hacinamiento y la insalubridad, son las causas primordiales de esa precaria condición de salud".

Por último, también encontramos que en los últimos quince años han aumentado en Yucatán los municipios en la categoría de alta marginación. Resulta evidente la estrecha relación entre marginación y condición étnica: "en la medida que el promedio de hablantes de lengua indígena aumenta, lo hace también el grado de marginación y viceversa" (Báez y Flores 2008:100). Así, el municipio con mayor monolingüismo en Yucatán, Tahdziú, es el que ocupa el primer lugar en marginación en el estado. 
En los municipios indígenas y predominantemente indígenas la población de 6 a 14 años que no asiste a la escuela son de 6.4 y $5.5 \%$ respectivamente; en los municipios indígenas $20.7 \%$ de la población no sabe leer y escribir, y el $18.1 \%$ de la población de 15 años o más no tiene escolaridad. Asimismo, en los municipios indígenas y predominantemente indígenas el 62 y $66 \%$ de la población no tiene derechos a servicios de salud. Y "en municipios indígenas, 33.1\% de la población ocupada no recibe ingresos; $37.2 \%$ recibe menos de un salario mínimo mensual, $22 \%$ recibe de uno a dos salarios mínimos y solamente $16.3 \%$ recibe más de dos salarios mínimos, en promedio" (Báez y Flores 2008:110).

¿Cómo interpretar estos datos en términos de la etnicidad maya? O ¿cómo han sido interpretados? La antropología sociocultural de Yucatán tuvo en sus orígenes (décadas de los treinta y cuarenta del siglo $\mathrm{XX}$ ) una vocación temática decididamente mayista, tal como se puede apreciar en las obras de Robert Redfield, Alfonso Villa Rojas y Alfredo Barrera Vásquez. Sin embargo, durante las décadas de los setenta y ochenta de ese mismo siglo, la temática mayista se desdibujó en un paisaje intelectual en el que predominaba la economía política marxista y la temática campesina. Fue a partir de la década de los noventa que, en el marco del "giro cultural" de la antropología mexicana, la temática mayista cobró una nueva presencia en la discusión local, regional, nacional y mundial (Krotz y Llanes 2011).

En el marco anterior, una de las primeras líneas de análisis que rompió con el desdibujamiento de la temática mayista está constituida por una serie de investigaciones etnohistóricas que se han centrado en los procesos de resistencia y en los espacios de autonomía del "Pueblo Maya" a partir de la Conquista; procesos y espacios que, junto con el tema de la identidad maya, son analizados hasta la actualidad en contextos de marginación y pobreza. ${ }^{5}$

También encontramos un conjunto de estudios que se han ocupado de la temática mayista a partir del problema de la identidad étnica. Estos estudios ${ }^{6}$ han constatado cómo diversos rasgos culturales (entre ellos la lengua, el vestido tradicional, la organización familiar, los apellidos, la celebración de santos patronos) de los maya hablantes persisten

\footnotetext{
${ }^{5}$ Véanse las diversas investigaciones realizadas en el CIESAS Peninsular, por ejemplo, Bracamonte (1994, 2001 y 2010 ), Bracamonte y Lizama (2006), Lizama (2007).

${ }^{6}$ Por ejemplo, Negroe (1990), Lara (1996; 2004), Guzmán (2005).
} 
en la actualidad y funcionan como diacríticos que los distinguen de los no mayas. Han argumentado, también, la continuidad de una matriz cultural o núcleo duro cultural a partir del cual se resignifican elementos externos a la cultura de origen. Sin embargo, estos estudios, los datos que revelan, apuntan más hacia el tema de la reproducción cultural que hacia el de las reivindicaciones étnicas y procesos de etnogénesis.

El vacío etnográfico sobre los mayas de Yucatán ${ }^{7}$ está siendo salvado en cierta medida gracias al proyecto de largo aliento del INAH denominado "Etnografía de las regiones indígenas de México en el nuevo milenio". En el marco de este proyecto, los investigadores del Centro Regional Yucatán del INAH han logrado recoger un material etnográfico de gran riqueza que cubre diversos temas (desde cosmovisión hasta organización social) y regiones de la península. Respecto al tema de la etnicidad e identidad étnica maya, han documentado distintos elementos que funcionan como diacríticos: la lengua, los apellidos, la indumentaria, la participación en prácticas culturales consideradas tradicionales, y cómo estos diacríticos, junto con los diversos etnónimos, varían regionalmente. De especial interés para esta investigación es uno de los hallazgos realizados por una de las investigadoras de este proyecto, relativo a la existencia de dos formas identitarias de la población maya hablante de la península a partir de la Revolución mexicana. Cito in extenso:

Una podría ser entendida como la de los descendientes de los mayas [es decir, lo que en esta tesis denomino mayas]. Es propia de hijos de los llamados mestizos en Yucatán y Campeche. Han concurrido a la escuela, son maestros, promotores, ingenieros, médicos. Admiran a sus ancestros, sobre todo a los del pasado remoto, y sobre dicho pasado y sus glorias construyen una identidad afirmativa que sin embargo busca la superación de las manifestaciones más atrasadas de la forma de vida actual de los mayas.

Otra forma de la identidad maya en esta región es la de los mestizos. Tienen por lengua materna el maya, son campesinos pobres y asalariados. Las mujeres visten de hipil y el hombre conserva algunos de los rasgos de la indumentaria de mestizo (alpargatas, sombrero). Apenas logran enviar a sus hijos a la escuela y por lo general piensan que son pobres porque siempre han sido pobres. Sus hijos, cuando logran un trabajo bien

\footnotetext{
${ }^{7}$ Más de un especialista en la región considera que, después de la célebre etnografía de Villa Rojas sobre los mayas de Quintana Roo (los "elegidos de Dios"), no contamos con ninguna etnografía exhaustiva sobre tal población. Le debo esta apreciación al antropólogo y especialista mayista Mario Humberto Ruz (entrevista con M. Ruz, 2007).
} 
remunerado y entran en contacto cotidiano con la gente de la ciudad, suelen considerarse wíiros, gente poco educada y sin conocimiento de las cosas importantes. En la ciudad hablan maya entre ellos pero también tienden a negar ante los no mayas su conocimiento de la lengua materna. Por lo general ignoran que sus antepasados son los mundialmente admirados mayas (Quintal 2005:365-366).

El tema de la cultura maya también ha cobrado mayor presencia en las investigaciones sobre los distintos procesos legales que están teniendo lugar a nivel nacional, regional y estatal. En este sentido, encontramos ya algunos estudios sobre sistemas de normas, de resolución de conflictos, de derecho indígena y derechos humanos en la región, así como sobre el problema de la movilización étnica. ${ }^{8}$ También comenzamos a contar con estudios sobre la etnicidad maya en el ámbito urbano, en donde los profesionistas de clase media son el tema central. ${ }^{9}$

A pesar de la heterogeneidad teórica y metodológica de los conjuntos de trabajos arriba señalados, se puede afirmar que, en términos generales, comparten una concepción cultural (o "neocultural" [Krotz y Llanes 2011]) que los dirige a centrarse en el tema de la reproducción cultural, como, por ejemplo, en la persistencia de prácticas culturales o de una cosmovisión. Asimismo, a pesar de que constituyen un gran aporte para el conocimiento etnográfico y etnohistórico de la población maya hablante de la región, han problematizado poco la existencia del "Pueblo Maya" como una unidad identitaria: del hecho de compartir cultura (un núcleo duro cultural o una matriz cultural) y una historia no se sigue la existencia de una identidad étnica. Diversos estudiosos extranjeros, algunos de ellos identificándose bajo la categoría de "antropología histórica", han cuestionado justo la idea de la existencia de una identidad étnica maya. Veamos.

El antropólogo alemán Harald Mossbrucker (1992) ha apuntado críticamente que una cultura compartida no significa poseer una identidad étnica y ha concluido que los mayas de Yucatán no conforman una etnia ni poseen una identidad étnica. Si bien comparto sus postulados teóricos (su crítica al isomorfismo entre cultura y etnia), me parece que comete caros errores metodológicos. Mossbrucker estudió dos sectores

\footnotetext{
${ }^{8} \mathrm{Al}$ respecto, pueden verse los diversos trabajos incluidos en las obras colectivas coordinadas por Krotz (1997; 2001; 2008; 2015b). Sobre el tema de movilización étnica puede verse Mattiace (2009 y 2013) y Mattiace y Llanes (2015).

${ }^{9}$ Véase, sobre todo, López Santillán (2011). Sobre este trabajo me detendré en el capítulo III.
} 
poblacionales, ambos ubicados en la zona periurbana de Mérida, entre los que no se presenta forma alguna de identidad étnica (por ejemplo, los encuestados perciben la guerra de castas como un evento negativo y la conquista española como uno positivo). Pero al generalizar esta situación a todos los maya hablantes de Yucatán, Mossbrucker sucumbió en un vértigo reduccionista en el que pasa por alto la diversidad de categorías y formas de identificación en Yucatán (que bien ha documentado Quintal [2005]).

Ante este escenario, la "antropología histórica" sobre los mayas de Yucatán cuestiona la "presupuesta unidad, identidad y etnicidad de los mayas de Yucatán" (Castañeda 2004:3), ya sea la que postula la existencia de una identidad étnica para todos los maya hablantes o la que la niega, y se centra en cambio en los usos de categorías, en las relaciones de poder y de desigualdad, así como en los discursos y construcciones sobre lo maya. En pocas palabras, han demostrado que "la etnicidad de los mayas ya no es más un presupuesto dado y estable" (Castañeda 2004:4). Y han llegado a conclusiones provocadoras. Revisemos algunas de ellas.

El historiador británico Matthew Restall (1997) ha argumentado que en el período colonial no sólo no se usaba el término "maya" como categoría de auto-identidad, sino que no existía una conciencia étnica que aglutinara a todos los maya hablantes. Antes bien, la identidad de éstos estaba definida en términos del cah (comunidad) y el chibal (patronímico) y no en términos de una comunidad lingüística. ${ }^{10}$ Esta tesis es clave para desafiar al argumento de la revitalización étnica y sobre ella volveré con mayor detalle en el capítulo III.

Por su parte, el antropólogo norteamericano Quetzil Castañeda (1996), desde un enfoque postestructural, ha estudiado cómo en la articulación entre cultura maya, antropología y turismo se ha gestado un "museo de la cultura maya", un metafórico museo en el que se escribe e inscribe constantemente "lo maya" en complejas tramas de saber-poder. "El museo de la cultura maya es —nos dice Castañeda (1996:98)—, entonces, una orquestación estratégica tanto de conocimiento de los mayas como de la producción de este conocimiento, es un aparato a través del cual la cultura maya es inventada y continuamente reinventada en un texto". El museo de la cultura maya está

\footnotetext{
${ }^{10}$ En términos de Evans-Pritchard (1997:152-153) diríamos que la "relatividad estructural" abarcaba los niveles de la unidad doméstica, la comunidad y el grupo patronímico, pero no llegaba al nivel del grupo lingüístico.
} 
inscrito con tropos de misterio y regula la producción de conocimiento e imágenes sobre los mayas. En buena medida, retomo su estrategia de analizar relaciones entre diversos actores y sus distintas tramas conceptuales para apreciar cómo se constituye lo maya (ciertamente con tropos de misterio, de grandeza, etcétera). Pero también hay que atender a cómo se construye lo no maya, lo mestizo, pues esta categoría también involucra tramas de saber-poder.

En años más recientes, el antropólogo alemán Wolfgang Gabbert (2004) ha cuestionado la idea de la existencia de dos grupos étnicos claramente delimitados en Yucatán (el maya y el no maya), aunque sí reconoce la existencia de un sistema de categorías étnicas que funciona de manera situacional. Al igual que Restall, postula que no existe una conciencia étnica que abarque a todos los maya hablantes. Un punto particularmente polémico de su investigación es que la etnicidad maya no fue un factor causal de la guerra de castas del siglo XIX; por el contrario, la etnogénesis fue un resultado de dicho conflicto, y fue algo privativo a un sector de la población (los denominados (ruzoob).

Comparto muchos de los postulados que la antropología histórica ha formulado sobre los mayas de Yucatán. Pero los tomo como punto de partida. O mejor, como punto de ruptura epistemológica: cuestionan la existencia de una identidad étnica maya, de la etnicidad maya. Sin embargo, en tanto que en los últimos años encontramos algunos sectores poblacionales que se identifican y son identificados como mayas, e incluso como maayas, cabe preguntarnos ¿cómo se han mayanizado los mestizos yucatecos?, ¿qué demandas y reivindicaciones plantean? 
PRIMERA PARTE. PODER Y ETNICIDAD: DISCUSIÓN TEÓRICA 


\section{PODER Y ETNICIDAD: DISCUSIÓN TEÓRICA}

\section{Introducción}

El objetivo de este capítulo es analizar teóricamente la relación entre poder y etnicidad. No pretende ser, en lo absoluto, una teoría general del poder. Tampoco quiere ser una teoría general de la etnicidad. Si bien este análisis parte de un caso histórico y etnográfico particular, la etnicidad maya en Yucatán, tampoco he pretendido elaborar un saco teórico que sólo le venga a mi caso de estudio. En otras palabras, mi objetivo es que el trabajo teórico realizado en este capítulo sirva también para analizar las relaciones entre poder y etnicidad en una diversidad de casos, o al menos que sea útil para formular algunas preguntas y orientar tentativas de respuestas. De entrada anuncio que no es un trabajo teórico formulado únicamente por inquietudes académicas, sino para comprender una serie de fenómenos políticos asociados con lo que se ha caracterizado como la “emergencia indígena en América Latina” (Bengoa 2000), por ejemplo, ¿cómo entender la dominación étnica?, ¿cómo comprender las reivindicaciones y resistencias étnicas y sus posibilidades y limitaciones para la transformación del orden sociocultural existente, por lo demás sumamente desigual? ${ }^{11}$

En este trabajo teórico me he propuesto operar con una simetría analítica con respecto a los problemas de dominación y resistencia. Como ha apreciado Sherry Ortner (2006), el fenómeno del poder se puede visualizar en un continuum que va desde la dominación total hasta la resistencia más ferviente, pasando por la hegemonía como una suerte de término medio. En este sentido, considero que un trabajo teórico sobre el poder

\footnotetext{
${ }^{11}$ No debemos perder de vista que América Latina es la región más desigual del planeta. Un aspecto constitutivo de esta desigualdad es, justamente, la relación entre poder y etnicidad, aunque, desde luego, no es el único factor que explica la producción y reproducción de la desigualdad en la región. Véase Reygadas (2008).
} 
debe ser capaz de explicar tanto la dominación como la resistencia, por ejemplo, cuáles son las bases de cada una, así como las fuentes de su ambivalencia. Del mismo modo, he procurado que la simetría sea también histórica, esto es, que pueda analizar de manera satisfactoria el fenómeno del poder en épocas históricas distintas. Por último, espero que este trabajo también sea simétrico en términos de lo que en ocasiones se ha planteado como dos dimensiones del poder: una material y otra ideal o simbólica. En realidad, como se verá más adelante, dicha distinción es sumamente problemática y probablemente no deba sostenerse más.

El orden de la exposición es el siguiente. Primero abordaré lo que podríamos considerar la comprensión dominante del poder en nuestros días, constituida, de un lado, por la analítica del poder formulada por el filósofo francés Michel Foucault (pero también por desarrollos ulteriores de otros autores) y, del otro, por análisis sobre las formas de dominación y resistencia actuales (en buena medida influidos por la analítica del poder de Foucault). Debido a su importancia para mi investigación, en segundo lugar me detendré particularmente en las discusiones teóricas planteadas por el poscolonialismo, el programa de la colonialidad/modernidad y el giro decolonial. En tercer lugar presentaré la propuesta teórica sobre el poder del antropólogo Eric R. Wolf y me detendré en uno de sus elementos centrales, la teoría del poder social desarrollada por el también antropólogo Richard N. Adams (y que Wolf caracteriza como "poder táctico" u "organizacional"). Como veremos más adelante, las propuestas de Foucault, por un lado, y las de Wolf y Adams, por otro, pueden parecer, en diversos aspectos, contradictorias entre sí. Ciertamente tienen puntos antagónicos, los cuales desarrollaré en su momento. Pero también podemos hallar fecundos puntos de encuentro, apenas anunciados por Wolf y que valdría la pena formular con mayor detenimiento, entre ellos la integración entre aspectos materiales y simbólicos del poder. En cuarto y último lugar sintetizo elementos de la discusión teórica presentada y expongo mi propuesta de análisis teórico sobre la relación entre poder y etnicidad.

\section{De la analítica del poder a la dominación y resistencias contemporáneas}

La producción teórica sobre el poder es por lo demás abundante, si bien "poder" es un término que generalmente se da por sentado y que pocas veces es definido y precisado 
teóricamente. No puedo presentar aquí las diversas teorías existentes sobre el poder, por lo que deseo detenerme únicamente, en este momento, en una de las transformaciones teóricas sobre el tema que más impacto ha tenido en la antropología sociocultural, pero también en otros ámbitos, tanto académicos (como la sociología, la filosofía, los estudios culturales y literarios, entre otros espacios disciplinarios), como políticos (especialmente en diversos movimientos sociales, incluyendo los étnicos). Me refiero a la transición del análisis marxista del poder, generalmente centrado en la dominación de clase (a partir de la propiedad de los medios de producción) y en la dominación ideológica, a la analítica del poder desarrollada por el filósofo francés Michel Foucault, uno de los autores más influyentes en las ciencias sociales y humanidades de las últimas décadas. ${ }^{12}$ En esta sección primero expondré los elementos constitutivos de la analítica del poder de Foucault. Después me detendré en cómo la analítica foucaultiana ha inspirado análisis de formas de dominación global (ámbito en el cual también se puede advertir la presencia de la teoría marxista), así como en las manifestaciones de resistencia a dicha dominación. Desde luego, los temas de dominación y resistencia contemporánea son sumamente numerosos, por lo que debo aclarar que mi interés está centrado en la dominación y resistencia relacionados con los fenómenos de etnicidad.

\section{La analítica del poder de Foucault}

La obra de Michel Foucault (1926-1984) es comúnmente dividida en tres etapas. ${ }^{13} \mathrm{La}$ primera es la "arqueología del saber", presente en obras como Historia de la locura en la época clásica, Las palabras y las cosas y, desde luego, en La arqueología del saber. El objetivo de esta arqueología es el examen de las condiciones de emergencia de determinados saberes y cómo la verdad nos constituye como sujetos de conocimiento; por ejemplo, cómo en la episteme del siglo XIX aparece en la cultura occidental el hombre como objeto del saber (Foucault 1982). En términos del filósofo francés Gilles Deleuze (1987), la arqueología del saber busca responder a la pregunta “¿Qué puedo saber?”. La segunda etapa, que es la que aquí más nos interesa, es la "genealogía del poder",

\footnotetext{
${ }^{12}$ De acuerdo con The Times Higher Education, Foucault fue el autor más citado en las humanidades en el año 2007. Véase: "Most cited authors of books in the humanities, 2007". Disponible en línea: $<$ http://www.timeshighereducation.co.uk/405956.article>.

${ }^{13}$ Véanse, por ejemplo, las caracterizaciones de G. Deleuze (1987; 1990); F. Gros (2007) y M. Morey (1990:25).
} 
representada en su ensayo "Nietzsche, la genealogía, la historia" y en dos libros, Vigilar y castigar (1975) y la Historia de la sexualidad 1. La voluntad de saber (1976). La genealogía analiza la forma en que las relaciones de poder, articuladas con tramas de saber, producen sujetos (y, como veremos más adelante, el cuerpo juega un papel central en esta genealogía). Deleuze sintetiza la genealogía del poder con esta pregunta: “¿Qué puedo hacer?". La tercera y última etapa de Foucault puede ser caracterizada como un conjunto de "tecnologías de sujetos" o de "subjetividad", en la cual se exploran las diversas tecnologías o técnicas que producen sujetos y en la que se destacan las relaciones éticas y las maneras en que nos constituimos como sujetos de acción moral. Deleuze resume esta etapa con la interrogante "¿Quién soy yo?".

Como todo orden clasificatorio, la caracterización de la obra de Foucault en tres etapas puede presentar múltiples anomalías, algunas ciertamente peligrosas. ¿Acaso Foucault no se interesó en el poder en la Historia de la locura?, ¿el saber ya no juega un papel central en su genealogía del poder?, ¿el tema del cuerpo no atraviesa tanto las obras tempranas (Historia de la locura, El nacimiento de la clínica) como las tardías de Foucault? Aquí sólo quiero detenerme en una de estas cuestiones, que ciertamente resultará central para la argumentación posterior: la transición de la concepción del poder de Foucault tal como se presenta en su arqueología y en su genealogía. Y aquí podemos apreciar el primer elemento constitutivo de la analítica del poder de Foucault: una concepción positiva del poder. ${ }^{14}$

En las obras tempranas de Foucault, notablemente en la Historia de la locura, el poder aparece en términos negativos: los "locos" que deambulan por las calles del siglo XVIII son rechazados, proscritos, excluidos, condenados al silencio, encerrados (Foucault 2012). Desde luego, esta concepción negativa no es privativa de la obra temprana de Foucault y, en realidad, es muy común encontrarla tanto en trabajos

\footnotetext{
${ }^{14}$ Cabe anotar que, según M. Morey, las diferencias entre la arqueología y la genealogía no son esenciales. "La diferencia entre arqueología y genealogía, escribe Morey (1990:14-15), es la que media entre un procedimiento descriptivo y un procedimiento explicativo: que la arqueología pretende alcanzar un cierto modo de descripción (liberado de toda "sujeción antropológica") de los regímenes de saber en dominios determinados y según un corte histórico relativamente breve; y que la genealogía intenta, por recurso a la noción de "relaciones de poder", explicar lo que la arqueología debía contentarse con describir. Esto es: por qué tal régimen de saber se desarrolla en tal dirección y según tales alcances y no en cualquier otro de los posibles". Según el propio Foucault, "la arqueología define y caracteriza un nivel de análisis en el dominio de los hechos; la genealogía explica o analiza el nivel de la arqueología" (citado en Morey 1990:16).
} 
académicos como en la opinión cotidiana, por ejemplo, con la idea de que, si bien el poder es algo deseado, una vez conseguido es algo que "corrompe". Pero la concepción positiva del poder de Foucault puede entenderse tal vez con mayor claridad si se contrasta con la concepción del poder marxista de la época, como en la famosa formulación de Louis Althusser sobre los "aparatos ideológicos" y los "aparatos represivos" del Estado. Comencemos, pues, con la idea de "represión".

Como ya se señaló arriba, para Foucault el poder ha sido conceptualizado sobre todo en términos negativos: reprime, rechaza, excluye. Foucault no niega esta realidad negativa del poder, pero va más allá al destacar su concepción positiva. De hecho, resulta interesante que Foucault proponga esta concepción positiva analizando uno de los espacios que se consideran más excluyentes, cuando no represivos, de la sociedad: la prisión. ¿En qué sentido el poder es "positivo” para Foucault? En su estudio sobre el nacimiento de la prisión, Vigilar y castigar (1975), Foucault formula como una de sus reglas generales de análisis no centrarse en los efectos represivos o de sanción de los mecanismos punitivos, "sino reincorporarlos a toda la serie de los efectos positivos que pueden inducir, incluso si son marginales a primera vista" (Foucault 2005:30. Cursivas de RL). El principal "efecto positivo" del poder es, para Foucault, la producción de saber y, sobre todo, la producción de sujetos. El poder produce, produce sujetos. Por ejemplo, Foucault indaga cómo a través de una serie de saberes jurídicos, médicos, psicológicos, entre otros, se producen los sujetos como criminales y como presos.

Tomemos ahora la idea de poder a través de su manifestación ideológica. Para Foucault, el poder no debe entenderse únicamente como dominación a través de una serie de ideas que afectarían principalmente a la conciencia de los individuos. El poder, según Foucault, afecta directamente a los cuerpos, y éste es un elemento constitutivo de su analítica: la relación del poder con el cuerpo. Cito in extenso un párrafo de Vigilar y castigar:

Pero el cuerpo está también directamente inmerso en un campo político; las relaciones de poder operan sobre él una presa inmediata; lo cercan, lo marcan, lo doman, lo someten a suplicio, lo fuerzan a unos trabajos, lo obligan a unas ceremonias, exigen de él unos signos. Este cerco político del cuerpo va unido, de acuerdo con unas relaciones complejas y recíprocas, a la utilización económica del cuerpo; el cuerpo, en buena parte, está imbuido de relaciones de poder y de dominación, como fuerza de producción; pero en 
cambio, su constitución como fuerza de trabajo sólo es posible si se halla prendido en un sistema de sujeción (en el que la necesidad es también un instrumento político cuidadosamente dispuesto, calculado y utilizado). El cuerpo sólo se convierte en fuerza útil cuando es a la vez cuerpo productivo y cuerpo sometido. Pero este sometimiento no se obtiene por los únicos instrumentos ya sean de la violencia [o de represión, RL], ya de la ideología (Foucault 2005:32-33).

Entonces, "ni represión ni ideología", tal como le gustaba a Deleuze (1995:13) caracterizar la analítica del poder de Foucault. En efecto, como hemos visto, el poder no sólo reprime, no sólo es negativo, sino que también es positivo, produce sujetos; del mismo modo, el poder no sólo opera a través de la ideología, sino, sobre todo, cerca los cuerpos. Tomemos ahora el último elemento de contraste con la idea de aparatos represivos e ideológicos del Estado: el Estado. Éste es un tercer elemento constitutivo de la analítica del poder de Foucault y, acaso, uno de los más reconocidos: el poder no está ubicado únicamente en el Estado, no es propiedad del gobernante (pues en realidad no es propiedad de nadie), no es una macroestructura (como el Estado), sino que es una microfísica que se manifiesta como estrategias, disposiciones y redes de relaciones dispersas por toda la sociedad. Vale la pena citar de nuevo, in extenso, a Foucault (2005:33-34):

Ahora bien, el estudio de esta microfisica supone que el poder que en ella se ejerce no se conciba como una propiedad, sino como una estrategia, que sus efectos de dominación no sean atribuidos a una "apropiación", sino a unas disposiciones, a unas maniobras, a unas tácticas, a unas técnicas, a unos funcionamientos; que se descifre en él una red de relaciones siempre tensas, siempre en actividad más que un privilegio que se podría detentar; que se le dé como modelo la batalla perpetua más que el contrato que opera una cesión o la conquista que se apodera de un territorio. Hay que admitir en suma que este poder se ejerce más que se posee, que no es el "privilegio" adquirido o conservado de la clase dominante, sino el efecto de conjunto de sus posiciones estratégicas, efecto que se manifiesta y a veces acompaña la posición de aquellos que son dominados. Este poder, por otra parte, no se aplica pura y simplemente como una obligación o una prohibición, a quienes "no lo tienen"; los invade, pasa por ellos y a través de ellos; se apoya sobre ellos, del mismo modo que ellos mismos, en su lucha contra él, se apoyan a su vez en las presas que ejerce sobre ellos. Lo cual quiere decir que esas relaciones descienden hondamente 
en el espesor de la sociedad, que no se localizan en las relaciones del Estado con los ciudadanos.

Parafraseando a Deleuze, podemos caracterizar hasta ahora la analítica del poder como "ni represión, ni ideología, ni Estado"; más bien: "producción de sujetos, cuerpo y microfísica”. ¿Cómo funcionan estos tres elementos en el análisis de la prisión en Vigilar y castigar? Antes de responder, quiero aclarar que no pretendo detenerme en los análisis específicos de Foucault. Si planteo la cuestión es porque su respuesta resulta central para la discusión que plantearé más adelante.

En Vigilar y castigar, Foucault emplea el concepto de "disciplina" cómo la prisión, a través de una microfísica del poder, es decir, una serie de estrategias, tecnologías y redes de relaciones, produce un determinado tipo de sujetos, los que él caracteriza como "cuerpos dóciles", que, en realidad, son cuerpos dóciles en lo político, pero productivos en lo económico. A esta disciplina que produce cuerpos dóciles Foucault la llama también "anatomía política".

Si bien Foucault, a diferencia de muchos de sus contemporáneos, nunca fue un gran simpatizante de Marx, y a pesar de los contrastes aquí trazados entre él y Althusser, su analítica del poder no resulta excluyente del análisis crítico de la economía política que hace Marx. Como se puede apreciar desde el Manifiesto del Partido Comunista, Marx y Engels fueron muy conscientes de la corporalidad de los obreros y cómo éstos, ante "el creciente empleo de las máquinas", "se convierte[n] en un simple apéndice de la máquina" (Marx y Engels 2008:131). Del mismo modo, señalaron cómo estos "esclavos de la máquina" están "colocados bajo la vigilancia de una jerarquía completa de oficiales y suboficiales" (Marx y Engels 2008:132). Ciertamente, como muchas de las aseveraciones del Manifiesto, estas ideas apenas son esbozadas, y si bien se pueden encontrar de forma más desarrollada en otros textos de Marx, ${ }^{16}$ no es mi interés formular

\footnotetext{
15 "A estos métodos que permiten el control minucioso de las operaciones del cuerpo - escribe Foucault (2005:141) — , que garantizan la sujeción constante de sus fuerzas y les imponen una relación de docilidadutilidad, es a lo que se puede llamar 'disciplinas'”. Más adelante, Foucault (2005:218) aclara que "La 'disciplina' no puede identificarse ni con una institución ni con un aparato. Es un tipo de poder, una modalidad para ejercerlo, implicando todo un conjunto de instrumentos, de técnicas, de procedimientos, de niveles de aplicación, de metas; es una 'física' o una 'anatomía' del poder, una tecnología".

${ }^{16}$ Véase, por ejemplo, el capítulo XI del primer tomo de El capital, titulado "Cooperación”, donde Marx analiza el cuerpo del obrero individual y el cuerpo del obrero colectivo (el cual "tiene ojos y manos por
} 
aquí la cuestión. Lo que sí me interesa destacar es que, como argumenta Foucault en Vigilar y castigar, el capitalismo necesitó para su surgimiento y desenvolvimiento no sólo un particular desarrollo de determinadas fuerzas productivas y relaciones de producción, sino, también, la producción de determinados tipos de cuerpos, dóciles y productivos, así como una serie de dispositivos de vigilancia no sólo para someterlos y reprimirlos, sino, insisto, para producirlos y reproducirlos. ${ }^{17}$ Dicho en otras palabras, en principio, la analítica del poder disciplinario sobre los cuerpos no resulta excluyente del análisis estructural de la economía política del capitalismo. Sobre esto volveré más adelante.

La idea de disciplina o anatomía política de los cuerpos también resulta crucial en otros aspectos. Por un lado, marca una época histórica en la que el poder funciona de una manera particular. Específicamente, Foucault distingue entre la Antigüedad, en donde el poder funcionaba de manera "espectacular" - como la "realeza divina" de los Shilluk estudiada por Evans-Pritchard (1987) o el Estado teatral balinés analizado por Geertz (1980) — , y la "época clásica", en donde el poder ya no recurre a dramatizaciones y espectáculos, sino a las silenciosas disciplinas que operan sobre los cuerpos. Es decir, Foucault traza una transición histórica de lo que podemos caracterizar como poder simbólico y performativo al poder disciplinario (a esta cuestión le dedicaré un apartado más adelante). Por otro lado, la idea de disciplina le sirve a Foucault como una crítica al racionalismo y humanismo de la Ilustración, pues, como apunta hacia el final de Vigilar y castigar, la Ilustración sólo ha sido posible en tanto que se ha sostenido sobre la base oscura de la disciplina.

Un año después de la aparición de Vigilar y castigar, Foucault publicó el primer volumen de su Historia de la sexualidad, titulado La voluntad de saber (1976). En él reafirma algunos de los postulados de su analítica del poder. Por ejemplo, en sus páginas

delante y por detrás" [1975:398]) y su relación con la "función directiva, vigilante y mediadora" del capital (1975:402). Todos estos elementos llevan a Marx a plantear, mas no a desarrollar, el problema de la resistencia (1975:402).

${ }^{17} \mathrm{Y}$, en este sentido, la tesis de la disciplina como constitutiva del capitalismo podría leerse bajo la lógica de Max Weber (2003), en el sentido de que el aspecto económico (productivo, en el caso de Marx) no explica por sí mismo el surgimiento y el desarrollo del capitalismo, porque también fue necesaria una "conducción de vida" [Lebensführung] ascética, a través de la ética protestante, para producir un determinado tipo de racionalidad o "espíritu" capitalista. Como se podrá apreciar, la idea de "conducción de vida" no resulta lejana a la idea del poder de Foucault como conducción de conducta de otros. 
encontramos el célebre pasaje sobre la "omnipresencia del poder"18 e insiste en la definición de éste como "la multiplicidad de las relaciones de fuerza inmanentes y propias del dominio en que se ejercen, y que son constitutivas de su organización" (Foucault 2009:113). Asimismo, en La voluntad de saber Foucault afirma que "el poder viene de abajo" (2009:114) y que "donde hay poder hay resistencia [...] ésta nunca está en posición de exterioridad respecto del poder" (2009:116). Del mismo modo, enfatiza que para el poder no existe "un lugar del gran Rechazo", sino, más bien, "varias resistencias que constituyen excepciones, casos especiales" (2009:116) al poder. Todas estas cuestiones serán centrales cuando veamos con mayor detenimiento los temas de dominación y resistencia.

Por último, en La voluntad de saber, Foucault introduce el concepto de "biopoder", el cual se ha vuelto central en los análisis contemporáneos sobre el poder en la antropología y otras disciplinas. El biopoder es definido como los mecanismos por medio de los cuales se administra la vida, y éstos son fundamentalmente dos: 1) la "anatomopolítica" o la "anatomía política del cuerpo", que refiere a la disciplina de los cuerpos individuales (el tema de Vigilar y castigar); y 2) la "biopolítica de las poblaciones", que alude a los mecanismos por medio de los cuales se regulan las poblaciones, tema que es desarrollado a lo largo de La voluntad de saber pero también en los cursos de Foucault en el Collège de France en la segunda mitad de la década de los setenta.

Si bien Vigilar y castigar y La voluntad de saber pueden considerarse las dos obras paradigmáticas de Foucault sobre el poder, lo cierto es que su análisis sobre el tema continuó transformándose, como se puede apreciar, por ejemplo, en sus trabajos sobre "gubernamentalidad" (2006), las distintas "artes de gobierno" europeas (2007), o en su famoso ensayo sobre "El sujeto y el poder" (1988). Me detendré aquí y pasaré a discutir algunos análisis sobre formas contemporáneas de dominación y resistencia, en los que, de hecho, se podrán apreciar algunas de esas transformaciones analíticas foucaultianas sobre el poder.

\footnotetext{
18 “Omnipresencia del poder: no porque tenga el privilegio de reagruparlo todo bajo su invencible unidad, sino porque se está produciendo a cada instante, en todos los puntos, o más bien en toda relación de un punto con otro. El poder está en todas partes; no es que lo englobe todo, sino que viene de todas partes" (Foucault 2009:113).
} 


\section{Dominación y resistencia en la era contemporánea}

Nuestra comprensión del poder, incluyendo los fenómenos de dominación y resistencia, no sólo depende de tradiciones de pensamiento singulares (desde Hobbes y Maquiavelo hasta Weber y Foucault), sino también de los procesos históricos particulares en los que estamos inmersos. De hecho, ambos elementos, teoría e historicidad, no se pueden entender como términos aislados, sino que son mutuamente constitutivos. ${ }^{19}$ Ya hemos visto uno de los elementos centrales en nuestra comprensión contemporánea del poder, la analítica de Michel Foucault. En lo que sigue me ocuparé en cómo algunos procesos históricos han influido en la manera en que entendemos el poder, particularmente en relación con el fenómeno de etnicidad. Éstos son: las formas de dominación contemporánea asociadas con el capitalismo de posguerra fría y la resistencia ejercida por movimientos sociales, especialmente a partir del levantamiento del Ejército Zapatista de Liberación Nacional (EZLN) en 1994. Ambos tienen al menos un elemento en común con la analítica de Foucault: el análisis del poder no en términos del Estado (o de algún otro centro), sino de redes de relaciones. ${ }^{20}$

En primer lugar, abordaré el tema de la dominación contemporánea, en el cual podemos encontrar dos posiciones que no son necesariamente excluyentes: por un lado, el planteamiento de que la dominación actual es producto de las transformaciones contemporáneas del capitalismo, que se manifiesta actualmente como "neoliberalismo"; por otro, la idea de que la dominación actual no es un fenómeno del todo nuevo, en tanto que la dominación "(pos)colonial” o la "colonialidad" tienen su origen en los inicios conjuntos de la modernidad, el capitalismo y el colonialismo.

Por lo común, dos fechas son consideradas paradigmáticas en la definición de la época en la que vivimos actualmente: 1973, año marcado por la crisis del petróleo y que da pie a una transformación del capitalismo (de uno industrial a otro posindustrial, de uno fordista a otro posfordista, de uno organizado a otro desorganizado, de uno temprano a uno tardío, etc.); y 1989, año que, con la caída del Muro de Berlín, ha sido caracterizado

\footnotetext{
${ }^{19}$ Tal como lo sugieren, entre otros, A. Giddens (2006) y P. Bourdieu (2009) con sus tesis sobre la "doble hermenéutica" y el "efecto de teoría", respectivamente.

${ }^{20} \mathrm{Y}$, desde luego, con la antropología política, que al menos desde 1940 ha descrito y explicado las relaciones de poder en sociedades "sin Estado" (Evans-Pritchard 2010; Fortes y Evans-Pritchard 2010).
} 
incluso como el "fin de la historia", en el sentido del fin de las alternativas civilizatorias al capitalismo. Ambas fechas son emblemáticas de dos procesos que, de acuerdo a diversos estudiosos, definen las formas de dominación contemporánea: el capitalismo tardío o neoliberalismo y el multilateralismo (Bell 1991; Harvey 1989; Lash y Urry 1987; Fukuyama 1992). En el análisis de estos fenómenos, la analítica del poder de Foucault, así como la economía política marxista, tienen un papel notable.

En este contexto, un elemento central para entender las actuales formas de dominación es que el poder no puede entenderse únicamente como atributo del Estado o del "poder soberano" radicado en el Estado, sino, más bien, el poder se despliega en una red de relaciones y fuerzas de carácter global, constituido especialmente por empresas y organismos económicos y financieros transnacionales. Además de las nuevas formas de organización del capital y su relación con la fuerza de trabajo, los conceptos de "biopoder" y de "biopolítica" de Foucault han sido claves en la interpretación de estas formas actuales de dominación. Por ejemplo, una de las obras paradigmáticas sobre el tema es Imperio, de Michael Hardt y Antonio Negri, publicada en el año 2000. La hipótesis de Hardt y Negri es que el orden político multilateral, de posguerra fría, está compuesto "por una serie de organismos nacionales y supranacionales unidos por una única lógica de dominio" (2002:14), a la cual llaman "imperio". A diferencia del imperialismo, el imperio "no establece ningún centro de poder y no se sustenta en fronteras o barreras fijas" (2002:14). Más bien, en términos de Foucault (aunque también, notablemente, de Deleuze), el imperio "es un aparato descentrado y desterritorializado ${ }^{21}$ de dominio que progresivamente incorpora la totalidad del terreno global dentro de sus fronteras abiertas y en permanente expansión" (2002:14). Lo que cabe destacar es que, para Hardt y Negri, el imperio es una forma de biopoder, de hecho, para ellos, la forma paradigmática del biopoder se "caracteriza principalmente por la falta de fronteras" (2002:16) y "penetra hasta las profundidades del mundo social" (2002:17). No obstante, el imperio también ofrece "nuevas posibilidades a las fuerzas de liberación" (2002:17),

\footnotetext{
${ }^{21}$ Habría que matizar este postulado. Pues, no sólo siguen existiendo centros territoriales de poder — desde Estados nación hasta empresas localizadas-, sino que también las tecnologías de información y comunicación, por más abstractas y desterritorializadas que nos puedan parecer, tienen sus soportes técnicos en territorios concretos.
} 
las cuales Hardt y Negri van a caracterizar como "multitud", y sobre la que volveré al tratar el tema de la resistencia.

Los trabajos del filósofo italiano Giorgio Agamben (1998) sobre el "poder soberano", el "estado de excepción" y la "nuda vida" también están cobrando una notable presencia en los análisis sobre el poder en la antropología y otras disciplinas. Agamben parte de la idea de biopolítica de Foucault, pero le reprocha a este último no haber analizado el fenómeno del totalitarismo y, particularmente, los campos de concentración. Para atender esta cuestión, analiza cómo la vida ingresa al ámbito de la política a partir de los conceptos de "nuda vida" - que es "la vida a quien cualquiera puede dar muerte pero que es a la vez insacrificable del homo sacer"22 (Agamben 1998:18)—, de "poder soberano" — quien decide sobre la vida y muerte de la nuda vida - y el "estado de excepción" - el cual es un estado de indeterminación entre derecho y violencia y hecho y derecho. ${ }^{23}$ Así como la prisión, las escuelas, los hospitales, las fábricas y los cuarteles eran espacios paradigmáticos de la disciplina en Foucault, para Agamben, el campo de concentración es el espacio por excelencia del poder soberano, el estado de excepción y la nuda vida. Los casos que analiza Agamben son, ciertamente, atroces, y van desde los judíos en los campos de concentración y que, como cobayas humanas, participaron en los experimentos nazis, hasta los comatosos y refugiados. Lo que cabe destacar es que la tesis de Agamben (1998:32-33) es que el estado de excepción ha tendido a convertirse en la regla y el campo de concentración se ha extendido a lo largo de la sociedad (así como, para Foucault, también lo habían hecho los espacios disciplinarios). De esto parecen dar cuenta, por ejemplo, los casos de Guantánamo, Iraq, Palestina, Darfur, así como las cancelaciones de derechos sociales de ciudadanos, sobre todo de los pobres, de muy diversos países. ${ }^{24}$ Además, el poder soberano no es un atributo del Estado, sino de otros agentes, desde médicos y científicos hasta organismos económicos y financieros transnacionales y organizaciones criminales de diversa escala.

\footnotetext{
${ }^{22}$ El "homo sacer" u "Hombre sagrado es, empero, aquél a quien el pueblo ha juzgado por un delito; no es lícito sacrificarle, pero quien le mate, no será condenado por homicidio" (Agamben 1998:94, n. 1).

${ }^{23}$ Hay que aclarar que el estado de excepción no es una suerte de estado de naturaleza que precede al orden social o a la cultura. Para Agamben (1998:30), "El estado de excepción no es, pues, el caos que precede al orden, sino la situación que resulta de la suspensión de éste".

${ }^{24}$ Sobre esta última cuestión, ver los trabajos de la antropóloga Ahiwa Ong (2006) acerca del neoliberalismo como excepción y del sociólogo portugués Boaventura de Sousa Santos (2009) sobre el fascismo social como una cancelación de derechos sociales asociada al neoliberalismo.
} 
Las ideas de "Imperio" y del "poder soberano" acaso puedan parecer demasiado abstractas para los antropólogos; de hecho, parecen haberse constituido en los nuevos grandes relatos de nuestra época. Lo cierto es que, desde la antropología, dichos conceptos, junto con los ya citados de biopoder y biopolítica, se han vuelto centrales en los análisis sobre las formas contemporáneas de dominación. No resulta difícil pensar en las poblaciones indígenas como una "multitud" desposeída de propiedad (ver Vázquez 2010) o como "nuda vida" desprovista de derechos sociales básicos. Desde luego, desde la antropología, hay que recuperar estos conceptos para analizar, a través de la etnografía, casos singulares y desde la perspectiva de los sujetos. ${ }^{25}$

Junto a estas nuevas manifestaciones de dominación asociadas a las transformaciones contemporáneas del capitalismo, la analítica del poder foucaultiana también ha sido influyente en las discusiones sobre la dominación colonial, la cual se remonta siglos atrás. Por su importancia para esta investigación, me detendré en las discusiones planteadas por el poscolonialismo antes de ocuparme del problema de la resistencia.

Lo que cabe enfatizar por el momento es que la dominación étnica no sólo se ejerce a través del Estado, sino que resulta clave entender la economía política contemporánea, que recurre a diversos bienes culturales, como todos los asociados con la "cultura maya" - las visitas a las zonas arqueológicas, artesanías, espectáculos, publicaciones, alimentos y todo un artesanal de mercancías clasificados como "mayas"- para la producción de valor; por otro lado, esta economía política también depende de la mano de obra barata de la gran mayoría de la población maya hablante del estado, ya sea en la industria de la construcción, como empleados de bajo nivel en la industria turística o como mano de obra migrante.

\footnotetext{
${ }^{25}$ Por ejemplo, Marc Abèlés (2008) ha analizado el escenario contemporáneo transnacional (compuesto por estados-nación, organizaciones no gubernamentales) como un resultado de un desplazamiento de lo político que, de ocuparse principalmente de la convivencia, tiene ahora en su núcleo una preocupación por la vida y por la supervivencia. Así, la lógica biopolítica de supervivencia es la que orienta la conducta de los individuos. Es también un régimen de temporalidad marcado ya no por el progreso, el bienestar y la emancipación, sino por la incertidumbre, el riesgo, la inseguridad y la precariedad (ver también Trouillot [2011], sobre la globalidad fragmentada y el régimen de temporalidad contemporáneo).
} 


\section{Poscolonialismo, colonialidad y giro decolonial}

Los movimientos teóricos y analíticos asociados con la teoría poscolonial, el programa colonialidad/modernidad y el giro decolonial, si bien son heterogéneos e incluso conflictivos entre sí, comparten una serie de preocupaciones y argumentos relativos al tema de la relación entre poder y etnicidad que deseo retomar. Todos ellos coinciden en una tesis fundamental: el fin del colonialismo político no implicó (al menos no necesariamente) el fin del colonialismo social y cultural. Es decir, el poder colonial, particularmente la dominación colonial, es un fenómeno que sigue presente en el mundo. Asimismo, una preocupación común en dichos movimientos es cómo descolonizar la sociedad y la cultura, incluidas, de manera importante, los saberes de las ciencias sociales y humanidades. ${ }^{26}$ Acaso el tema de la descolonización del conocimiento sea hoy una de las discusiones más recurrentes en la academia (aunque también en movimientos sociales y organizaciones de distinto tipo), tal como se puede apreciar en las numerosas publicaciones, tesis, cursos, congresos y otro tipo de eventos sobre el tema. ${ }^{27}$

Con fines de economía de redacción, me referiré a los estudios poscoloniales, el programa de colonialidad/modernidad y al giro decolonial con el término poscolonialismo o discusión poscolonial. Cabe aclarar que por poscolonialismo se entienden diferentes cosas, si bien todas ellas estrechamente relacionadas: refiere tanto a una serie de enfoques teórico-analíticos, así como a una situación histórica, política y sociocultural. ${ }^{28}$ Resulta imposible exponer aquí siquiera a los autores y obras más emblemáticas del poscolonialismo. Considero más pertinente destacar algunas de sus tesis fundamentales, señalar en qué aspectos hay continuidad con la analítica del poder de

\footnotetext{
${ }^{26}$ De acuerdo con Boaventura de Sousa Santos, la perspectiva pos-colonial tiene dos ideas muy "tajantes": "la primera es que el colonialismo político terminó, pero no así el colonialismo social o cultural" (Santos 2006:50), la otra, de carácter más epistemológico, es al análisis de la construcción teórica de las relaciones Norte-Sur y el intento de "pensar el Sur por fuera de esa relación" (Santos 2006:50). Santos añade una tercera, que es que "las estructuras de poder se ven mejor desde los márgenes" (Santos 2006:50).

${ }^{27}$ Aunque hay que advertir que el problema de la descolonización del conocimiento no es privativo a los estudios poscoloniales. Se encuentra, por ejemplo, en la filosofía de Deleuze y Guattari, en el giro ontológico de la antropología, en la emergencia de antropologías nativas o indígenas, en las investigaciones de co-labor, entre otros movimientos (desde luego, hay que reconocer que entre todos estos enfoques hay intercambios y no se pueden entender de manera independiente a la discusión sobre el poscolonialimo) (ver Llanes 2014).

${ }^{28}$ Así, Santos (2009:277) escribe que: "El poscolonialismo debe ser entendido en dos acepciones principales. La primera es la de un periodo histórico, el que sucede a la independencia de las colonias. La segunda es la de un conjunto de prácticas (predominantemente performativas) y de discursos que reconstruyen la narrativa colonial, escrita por el colonizador, y procuran sustituirlas por narrativas escritas desde el punto de vista del colonizado".
} 
Foucault arriba esbozada y destacar algunos aspectos críticos y problemáticos sobre los que deseo detenerme más adelante. Quiero aclarar que, si me detengo en la discusión poscolonial es porque, en tanto que actualmente cuenta con una notable presencia (¿hegemonía?) en la academia, especialmente en lo que refiere al análisis sobre poder y etnicidad, considero que merece un análisis crítico, pues creo que el conocimiento avanza no sólo a través de investigaciones empíricas, sino, sobre todo, por la confrontación crítica con el conocimiento establecido. Expongo entonces, a continuación, algunas de las tesis centrales de la teoría poscolonial, la colonialidad/modernidad y el giro decolonial sobre las que considero que debe establecerse una discusión crítica.

La primera tesis ya ha sido anunciada: 1) el fin del colonialismo político no implicó el fin del colonialismo social y cultural. Cabe ahora agregar elementos adicionales y constitutivos de esta tesis. Destaco particularmente dos. El primero es 1.1) un énfasis en la dominación a través de elementos simbólicos y performativos, tales como representaciones, hegemonía, ideología, discursos y saberes. Por ejemplo, en su célebre obra Orientalismo, el crítico de origen palestino Edward Said (2004) declara que no le interesa analizar "la verdad de Oriente", sino las representaciones de Occidente sobre Oriente. Retomando a Foucault, Said enfatiza las relaciones entre poder y saber presentes en representaciones y discursos. ${ }^{29}$ Así, en términos de Said, el orientalismo es un sistema cognitivo, basado en relaciones de poder, por medio del cual Occidente ha constituido a Oriente y a sí mismo.

Del mismo modo, otro aspecto constitutivo de la tesis anterior es 1.2) la ambivalencia e hibridez de los elementos simbólicos y performativos que sirven a la dominación colonial, aspecto que ha sido analizado especialmente por Homi Bhabha (2002).

Una segunda tesis compartida por todos estos movimientos teóricos es 2) el énfasis analítico en una escala geopolítica global, i.e., el sistema colonial mundial. Este tema fue desarrollado notablemente por la crítica india Gayatri Spivak (2003) en su polémico ensayo “¿Puede hablar el subalterno?”, donde crítica a Foucault y Deleuze por omitir de sus análisis la división internacional del trabajo y el problema de la ideología. Al igual

\footnotetext{
${ }^{29}$ Sobre este tema, Said también hecha mano de la noción de "hegemonía" desarrollada por Antonio Gramsci: "es la hegemonía —o, mejor, los efectos de la hegemonía cultural — lo que da al orientalismo la durabilidad y la fuerza de la que he estado hablando hasta ahora" (Said 2004:27).
} 
que Said, Spivak se interesa por el modo en que son representados los sujetos del tercer mundo en el discurso occidental, pero señala la necesidad de un análisis macroscópico del poder, que no puede derivarse de la microfísica del poder. ${ }^{30}$

Como es bien conocido, uno de los argumentos más controvertidos de Spivak fue que el subalterno no puede hablar. Este argumento sólo puede entenderse bajo la lógica de la relación entre división mundial del trabajo e ideología. Como bien señala Spivak, para Foucault y Deleuze, los oprimidos no necesitan de una teoría que les diga la verdad, o $s u$ verdad (como, por ejemplo, la explotación de clase), ya que ellos conocen y pueden hablar sobre sus problemas. Pero para Spivak esto sólo sucede en el primer mundo. En cambio, del otro lado de la división del trabajo el subalterno no se encuentra en condiciones de hablar, pues el discurso con el que podría hacerlo es el del colonizador; es decir, así como el subalterno carece de una historia propia, también está privado de una lengua para hablar, pues su lengua es la del imperialismo y la del patriarcado. ${ }^{31}$ Desde luego, no hay que tomar de manera literal el provocativo planteamiento de Spivak, sino considerarlo, insisto, en el marco de la división internacional del trabajo, de la ideología, así como de las condiciones dialógicas que se dan en el mundo poscolonial.

Acaso no sea propiamente una tesis, pero un tercer aspecto compartido presente en el poscolonialismo es, en el marco del énfasis en la relación entre poder y conocimiento y el nivel geopolítico global, 3) la búsqueda de la descolonización del conocimiento. Desde luego, este aspecto está estrechamente relacionado con las dos tesis arriba señaladas, por ejemplo, en la idea de que si la dominación colonial se ejerce a través del saber, luego, se puede concluir que el saber está colonizado; del mismo modo, bajo la lógica de argumentación de Spivak, si el saber está concentrado en el primer mundo o en la metrópoli, los subalternos no sólo no pueden hablar, sino que tampoco pueden producir saberes sobre sus propios problemas. La búsqueda de la descolonización del conocimiento ha conducido a plantear una serie de preguntas, tanto desde el lado de los colonizadores como del colonizado, tales como ¿quién escribe?, ¿desde dónde lo hace?,

\footnotetext{
${ }^{30}$ Escribe Spivak (2003:314) “debemos consolidar nuestra crítica en el siguiente sentido: la relación entre capitalismo global —explotación en lo económico-y las alianzas de los estados-nación — dominación en lo geopolítico - es tan macrológica que no puede derivarse de ella la textura micrológica del poder. Para moverse hacia tal explicación uno debe moverse hacia las teorías de la ideología — de formaciones del sujeto que micrológica y a menudo erráticamente operan los intereses que soldifican las macrologías-".

${ }^{31}$ Sobre estas cuestiones también puede verse el ensayo de Derrida (1997) sobre el monolingüismo del otro.
} 
¿para quiénes escribe?, ¿con qué fines?, ¿en qué lengua?, ¿a qué textos refiere?, ¿qué es lo que silencia? Esto también plantea varios problemas sobre el tema de la resistencia, sobre el que volveré más adelante. En el caso de la antropología, todas estas preocupaciones han dado lugar a proyectos tales como el de las World Anthropologies (Ribeiro y Escobar 2006), que se plantea la descolonización del conocimiento antropológico así como la construcción de una comunidad antropológica global verdaderamente dialógica (donde, parafraseando a Spivak, las y los antropólogos subalternos puedan hablar). La emergencia de antropólogos indígenas que se identifican como indígenas también se puede ubicar en esta tendencia.

Como respuesta a elementos problemáticos y críticos de las ideas de los estudios poscoloniales arriba expuestas, a inicios del presente milenio fue cobrando cuerpo lo que se ha conocido como programa de colonialidad/modernidad y el giro decolonial, dedicados al análisis del fenómeno colonial y los procesos de descolonización en América Latina. ${ }^{32}$ Diversos estudiosos han observado ya que la teoría poscolonial se ha basado principalmente en la experiencia del dominio colonial británico sobre Asia (y, en menor medida, África), y que el caso latinoamericano presenta problemáticas distintas. ${ }^{33}$ La tesis central de este programa es que, desde su punto de partida, la modernidad ha sido colonial. Es decir, la modernidad no sólo puede entenderse como "emancipación", “ilustración”, “cambio", “innovación”, “secularización”, “racionalidad”, entre otras características que los estudiosos le han atribuido, sino, ante todo, como una forma de dominación. Del mismo modo, la modernidad no comenzaría con el Renacimiento, la Reforma o la Ilustración, sino con la conquista de América y el colonialismo. La colonialidad es, así, el "lado oscuro" de la modernidad. En este orden de ideas, uno de los conceptos angulares de este programa es el de "colonialidad del poder", formulado por el

\footnotetext{
${ }^{32}$ Arturo Escobar (2003) hace una genealogía del programa de investigación modernidad/colonialidad, que va desde la teología de la liberación, la filosofía de la liberación, la propuesta de investigación-acción, las discusiones sobre una ciencia social autónoma, la teoría de la dependencia, las discusiones sobre modernidad y posmodernidad, sobre hibridez, así como los estudios subalternos latinoamericanos. Escobar también reconoce la influencia de las teorías críticas europeas y norteamericanas, del grupo sudasiático de estudios subalternos, la teoría feminista, la teoría poscolonial, la filosofía africana y las teorías del sistema mundo (2003:53).

${ }^{33}$ Ver, por ejemplo, las críticas de Santos (2009), quien analiza las particularidades del colonialismo portugués. Del mismo modo, el antropólogo brasileño Gustavo Lins Ribeiro (2003) plantea los problemas de una recepción acrítica del poscolonialismo en América Latina. "En América Latina - escribe Ribeiro (2003:43) - el poscolonialismo sería igual a lo que él mismo condena, un discurso externo sobre el Otro que llega a través de un poder metropolitano".
} 
sociólogo peruano Aníbal Quijano (2003), el cual es definido como una forma de clasificación social de la población que sustenta una división del trabajo basada en la categoría de raza. ${ }^{34}$ Así, tras la conquista de América, la población clasificada como india fue relegada a la servidumbre, la población categorizada como negra fue destinada a la esclavitud, y sólo los autoclasificados como blancos o europeos gozaron del trabajo pagado. Con un lenguaje muy similar al de Foucault, Quijano (2003:205) define la colonialidad del poder como "una nueva tecnología de dominación/explotación, en este caso raza/trabajo", que ha sido naturalizada. Así, ahí donde la teoría poscolonial analiza la persistencia actual de la dominación colonial a través de representaciones, discursos y narraciones, el programa de colonialidad/modernidad analiza la persistencia de la colonialidad del poder (que para Quijano va más allá de la conquista y se extiende hasta los proyectos de construcción de nación hasta llegar a las más recientes reformas neoliberales) e identifica distintas lógicas de colonialidad, además de la del poder, la colonialidad del saber y la colonialidad del ser. Todas estas categorías parten de una crítica al "eurocentrismo" como una perspectiva o racionalidad de conocimiento colonizadora, como la forma de conocimiento de la colonialidad/modernidad. ${ }^{35}$

Quiero destacar que el concepto de colonialidad del poder es, fundamentalmente, un orden clasificatorio (Durkheim y Mauss 1971; Douglas 1973) a partir del cual la realidad es categorizada. Hay que notar, también, que diversos conceptos de poder (tal como el "poder simbólico" de Pierre Bourdieu [1988; 2001], o la "geografía imaginaria" y el "nicho del salvaje" de Michel-Rolph Troulliot [2011]) son también, ante todo, formas de órdenes clasificatorios. En este sentido, hay que recordar, por un lado, que los órdenes clasificatorios no son neutrales en términos valorativos y que, por lo general, implican

\footnotetext{
${ }^{34}$ En palabras de Quijano (2003:201), la colonialidad del poder consiste en "la clasificación social de la población mundial sobre la idea de raza". También lo define como un patrón de poder basado en dos ejes: 1) "la codificación de las diferencias entre conquistadores y conquistados en la idea de raza" y 2) "la articulación de todas las formas históricas de control del trabajo, de sus recursos y de sus productores, en torno del capital y del mercado mundial" (2003:202).

35 De acuerdo con Quijano (2003:218), el "Eurocentrismo" es el "nombre de una perspectiva de conocimiento cuya elaboración sistemática comenzó en Europa Occidental antes de mediados del siglo XVII [...] Su constitución ocurrió asociada a la específica secularización burguesa del pensamiento europeo y a la experiencia y las necesidades del patrón mundial del poder capitalista, colonial/moderno, eurocentrado, establecido a partir de América". Más adelante (2003:219), añade que es "una específica racionalidad o perspectiva de conocimiento que se hace mundialmente hegemónica colonizando y sobreponiéndose a todas las demás, previas o diferentes, y a sus respectivos saberes concretos, tanto en Europa como en el resto del mundo".
} 
jerarquías; y por otro lado, que, como observó Mary Douglas, todo orden clasificatorio gesta anomalías. Precisamente, las anomalías pueden jugar un importante papel en la subversión o descolonización del orden clasificatorio colonial.

De hecho, en el programa de colonialidad/modernidad podemos encontrar una acentuada preocupación por los procesos de descolonización. En este orden de ideas, las categorías de "exterioridad", formulada por el filósofo argentino-mexicano Enrique Dussel (2004), así como las de "pensamiento fronterizo" del semiólogo argentino Walter Mignolo (2011), resultan clave. Es desde la exterioridad al sistema mundo colonial y en sus fronteras, particularmente en sus expresiones de pensamiento fronterizo, donde los defensores de este programa encuentran el potencial descolonizador. Asimismo, estas categorías plantean el tema de la resistencia y los de emancipación y liberación, sobre los que volveré más adelante.

En todos estos elementos podemos apreciar la influencia de la analítica del poder de Foucault. En primer lugar, la concepción positiva del poder, la idea de que el poder produce sujetos, se puede apreciar en el hecho de que la dominación (pos)colonial produce sujetos coloniales, tanto al sujeto colonizador como al sujeto colonizado. Aún más, cual dialéctica hegeliana del amo y el esclavo, el sujeto colonizador y el sujeto colonizado se producen mutuamente en un juego de espejos. Said es enfático en cómo Occidente ha necesitado de Oriente para definirse; ${ }^{36}$ para Quijano, Europa, particularmente Europa occidental, sólo pudo constituirse después de constituir América bajo la lógica de la colonialidad del poder. Del mismo modo, el tema del cuerpo es central en todas estas discusiones, pues mientras que la dominación colonial produce al sujeto colonizador, europeo, como sujeto de razón, hace del sujeto colonizado un cuerpo sin razón o sin alma. ${ }^{37}$ Asimismo, el cuerpo del sujeto colonizado es un cuerpo marcado,

\footnotetext{
${ }^{36}$ Según Said (2004:53), el poder-saber del Orientalismo "crea "al oriental"” al mismo tiempo que "lo elimina como ser humano".

${ }^{37}$ Sobre esta cuestión hay una bibliografía abundante. Un pasaje paradigmático es la discusión entre Bartolomé de las Casas y Ginés Sepúlveda sobre si los naturales de América poseían alma o no; un pasaje semejante se encuentra en Tristes trópicos de Claude Lévi-Strauss y sirve de motivo al etnólogo brasileño Eduardo Viveiros de Castro (2010) para su trabajo sobre el perspectivismo amerindio. Para Quijano, el cuerpo es central en la colonialidad del poder: el cristianismo privilegió el alma sobre el cuerpo, y la tradición cartesiana hizo lo suyo otorgando primacía a la razón y desdeñando al cuerpo. "Sin esa 'objetivización' del 'cuerpo' como 'naturaleza', de su expulsión del 'espíritu', difícilmente hubiera sido posible intentar la teorización 'científica' del problema de la raza, como fue el caso del Conde de Gobineau
} 
es un cuerpo de color ("negro" o "café"), un cuerpo bárbaro y salvaje. Por último, el foco de análisis no es el Estado en sí mismo, sino discursos, representaciones, símbolos y performances que, si bien pueden ser también producidos y reproducidos por el Estado, van mucho más allá de él. ${ }^{38}$ Desde luego, la relación entre poder y saber atraviesa todas estas cuestiones.

Hay que advertir que una de las principales diferencias del poscolonialismo con Foucault es, como insistió Spivak, el descuido de aquél por la geopolítica. ${ }^{39}$ Este problema ha sido abordado por Santiago Castro-Gómez (2010), quien ha argumentado que Foucault desarrolló "una analítica heterárquica del poder", heurísticamente más provechosa que las concepciones jerárquicas del poder que han predominado en los estudios poscoloniales y en el programa de colonialidad/modernidad. Castro-Gómez reconoce junto con Spivak las limitaciones de los trabajos genealógicos de Foucault sobre el poder disciplinario, pero identifica que, hacia finales de la década de los setenta, Foucault también desarrolló una concepción macroscópica del poder, por ejemplo, en los análisis sobre la biopolítica de las poblaciones, los fenómenos de racialización, las técnicas y artes de gobierno, entre otros temas. Así, en palabras de Castro-Gómez (2010:284):

Foucault distingue tres niveles de generalidad en el ejercicio del poder: un primer nivel, microfísico, en el que actuarían las tecnologías disciplinarias y de producción de sujetos, así como las 'tecnologías del yo' que buscan una producción autónoma de la subjetividad. Éste

durante el siglo XIX. Desde esa perspectiva eurocéntrica, ciertas razas son condenadas como 'inferiores' por no ser sujetos 'racionales"” (Quijano 2003:224).

${ }^{38}$ Por ejemplo, es claro que el foco de análisis de Said no es el Estado, sino textos, desde académicos hasta literarios. Hay que advertir que Said no simplifica la relación entre saber y poder y, por el contrario, reconoce que los discursos no se corresponden directamente con el poder político, sino que se entrelazan con distintos tipos de poder. Para Said (2004:34-35), el orientalismo "es, sobre todo, un discurso que de ningún modo se puede hacer corresponder directamente con el poder político, pero que se produce y existe en virtud de un intercambio desigual con varios tipos de poder: se conforma a través de un intercambio con el poder político (como el estado colonial o imperial), con el poder intelectual (como las ciencias predominantes: la lingüística comparada, la anatomía o cualquiera de las ciencias de la política moderna), con el poder cultural (como las ortodoxias y los cánones que rigen los gustos, los valores y los textos); con el poder moral (como las ideas sobre lo que 'nosotros' hacemos y 'ellos' no pueden hacer o comprender del mismo modo que 'nosotros'). De hecho, mi tesis consiste en que el orientalismo es $-\mathrm{y}$ no solo representa - una dimensión considerable de la cultura, política e intelectual moderna, $\mathrm{y}$, como tal, tiene menos que ver con Oriente que con 'nuestro' mundo".

${ }^{39}$ De acuerdo con Spivak (2003:332-333): "Foucault es un pensador brillante del poder-entre-líneas, pero la conciencia de la reinscripción topográfica del imperialismo no informa sus presuposiciones [...] La clínica, el asilo, la prisión, la universidad - todo parece ser una pantalla-alegoría que oscurece la lectura de las narrativas más amplias del imperialismo. (Uno podría abrir una discusión similar del feroz motivo de ‘desterritorialización' en Deleuze y Guattari)”. 
sería el nivel de la corpo-política. Luego tenemos un segundo nivel, mesofísico, en el que se inscriben los dispositivos internos de seguridad que harán posible la gubernamentalidad del Estado moderno y su control sobre las poblaciones. Éste sería el nivel de la bio-política. Por último tenemos un tercer nivel, macrofísico, en el que se ubican los dispositivos supraestatales de seguridad que favorecen la 'libre competencia' por los recursos naturales y humanos del planeta. Éste sería el nivel de la geo-política. Quisiera llamar heterárquica a esta analítica del poder.

Lo que hay que destacar es que en la analítica heterárquica del poder, el nivel geopolítico (i.e., el colonialismo) no determina necesariamente el nivel microfísico o de la corpo-política. Esta idea resulta particularmente importante para el tema de la etnicidad, pues, como plantea Castro-Gómez, mientras que para el programa de colonialidad/modernidad y el análisis de los sistemas mundo la etnicidad está relacionada principalmente con el problema de la etnización de la fuerza de trabajo,

desde una perspectiva heterárquica $[. .$.$] las relaciones de poder articuladas por la etnicidad$ no se generan primero en los regímenes globales sino en los más locales. Los regímenes globales funcionan simplemente como 'aparatos de captura' que se apropian de relaciones de poder ya constituidas previamente en los niveles microfísicos para incorporarlos en su propia lógica [...] la etnicidad y la raza son formaciones discursivas que históricamente se articulan, por un lado, con la Corpo-política de los individuos y, por el otro, con la biopolítica de los Estados (Castro-Gómez 2010:288).

En otras palabras, podemos argumentar que, en un nivel macro, la etnicidad puede estar vinculada fundamentalmente con la fuerza de trabajo. Sin embargo, en otros niveles, como el meso y el micro, la etnicidad puede presentar otras relaciones más importantes. El problema de la etnicidad no se reduce a la cuestión de la fuerza de trabajo, sino que, como veremos, también se puede entender en relación con otras dimensiones del poder.

Llegados a este punto, es momento de detenernos en una serie de cuestiones problemáticas y críticas planteadas por el poscolonialismo. Uno podría seguir una lógica de contra-argumentación que resalte lo que la discusión poscolonial omite. Por ejemplo, si el poscolonialismo enfatiza la dominación a nivel simbólico-performativo, podemos 
señalar que descuida las dimensiones materiales y económicas de la dominación; ${ }^{40} \mathrm{o}$ bien, si otorga prioridad a la geopolítica global, podemos indicar que deja de lado la micropolítica. Pero también hay otros peligros en juego. Me detengo en dos.

Por una parte, la insistente búsqueda en la descolonización del conocimiento puede conducirnos a lugares problemáticos. Desde luego, el problema no es el fin en sí mismo, sino los medios que se emplean para alcanzarlo. No es extraño escuchar en congresos, seminarios, cursos y publicaciones comentarios que contraponen epistemologías, teorías y/o antropologías del Sur a las del Norte, señalando que, mientras que éstas son coloniales, aquellas son descolonizadoras y, en consecuencia, mejores. El problema no es la distinción en sí, sino cuando se reifican entidades ("Norte", "Sur", "Europa", "pueblos originarios", etc.) y se sucumbe en esencialismos nativistas en los que los nativos del Sur parecieran tener la razón sólo por ser nativos y del Sur. ${ }^{41}$ El peligro es que los saberes del Sur se vuelvan inmunes a la crítica. Por otra parte, incluso cuando se reconoce el carácter "híbrido" de los fenómenos socioculturales, como ha observado el antropólogo francés Jean-Loup Amselle (s.f.:9), la insistencia en lo "híbrido" posmoderno niega o aminora "toda posibilidad de contacto o de intercambio entre culturas antes de los descubrimientos y conquistas europeas", pues sólo los considera en la época contemporánea.

El segundo aspecto problemático es que el énfasis en la dominación colonial puede descuidar, cuando no invisibilizar, otras formas de dominación. ${ }^{42} \mathrm{Y}$ esto, aunado al

\footnotetext{
${ }^{40}$ Por ejemplo, Hardt y Negri escriben que los estudios poscoloniales aciertan en su hincapié en "la efectividad de los modos de representación y de las construcciones ideológicas para demostrar la naturaleza omnipresente o incluso omniabarcante del poder colonial" (2012:92) y en que "demuestran el modo en que la colonialidad se consigue y se mantiene no sólo mediante la violencia y la fuerza [...] sino también mediante al menos el consentimiento tácito ante los modos de conciencia y las formas de conocimiento coloniales que se extienden sin límites por toda la sociedad" (2012:93). Sin embargo, argumentan que "las nociones de ideología y representación no van lo suficientemente lejos para aferrar la profundidad del complejo modernidad-colonialidad-racismo" (2012:94). En este sentido, Hardt y Negri prefieren hablar de la "colonialidad del biopoder" para enfatizar la materialidad del poder: "Los poderes de la modernidadcolonialidad-racismo nunca han sido fenómenos meramente superestructurales, sino que son más bien aparatos materiales que atraviesan la existencia colectiva de las poblaciones dominadas y engloban sus cuerpos, produciendo internamente las formas de vida" (2012:95).

${ }^{41}$ Es fundamental reconocer que ni la "epistemología del Sur" de Santos (2009), la "teoría desde el Sur" de los Comaroff (2012) o las "antropologías del Sur" de Krotz (2011) son productos únicamente del Sur. Por el contrario, todos ellos enfatizan los intercambios (si bien desiguales), traducciones y apropiaciones de conocimiento entre el Norte y el Sur.

${ }^{42}$ Por ejemplo, las críticas marxistas al poscolonialismo americano señalan que éste no retuvo el aporte positivo del pensamiento de Gramsci y que descuidan el análisis de las clases sociales (Amselle s.f.:26-27).
} 
segundo aspecto crítico mencionado (la tensión entre geopolítica y microfísica), nos lleva a dos problemas que considero fundamentales: los problemas de escala y de duración. Es decir debemos ser conscientes que el poder (tanto la dominación como la resistencia) funciona a diversas escalas o niveles, y que cada uno de ellos tiene una duración o temporalidad distinta. Una es la escala colonial, cuya longue durée puede remontarse cinco siglos atrás, y que, a su vez, puede expresarse en distintas escalas (desde la división internacional y racializada del trabajo hasta las representaciones, discursos y estereotipos cotidianos). Otra escala es la del Estado nación, con sus bio-políticas indigenistas. Una más es la escala capitalista, que si bien algunos podrían remontar su duración hasta los inicios del colonialismo, también podemos reconocer que su expresión más reciente, el capitalismo neoliberal, tiene una duración más breve, desde la década de los ochenta del siglo pasado. ${ }^{43}$ ¿Cómo entender la relación entre estas escalas o niveles y duraciones o temporalidades? Considero que los planteamientos teóricos de Wolf y Adams pueden ofrecer claves de análisis. Pero antes de pasar a ellos abordo el problema de la resistencia.

\section{El problema de la resistencia: del deseo a los guiones ocultos}

Ningún análisis teórico sobre el poder puede estar completo sin abordar el problema de la resistencia. Inmediatamente hay que advertir que en las teorías contemporáneas sobre el tema podemos encontrar una tensión recurrente entre elementos descriptivos (qué es la resistencia, cómo funciona, cuáles son sus bases) y elementos normativos (contra qué se debe resistir, cómo resistir, hacia dónde conducir la resistencia). Mientras que algunos estudiosos señalan que una teoría del poder debe servir para impulsar la resistencia y empujarla hacia la emancipación y la liberación (ver, notablemente, Holloway 2010), también se corre el peligro de que los ideales del estudioso se confundan o nublen la realidad descrita (una crucifixion by resistance, parafraseando a Adams). No abordaré aquí las cuestiones normativas del tema de la resistencia, a pesar de que pienso que revelan mucho de la concepción que se tiene de la resistencia como fenómeno. Deseo

\footnotetext{
${ }^{43}$ Boaventura de Sousa Santos ha planteado esta cuestión en términos de seis espacios-tiempo de poder: el doméstico, donde la forma de poder es el patriarcado; el de la producción, donde el modo de poder es la explotación; el de la comunidad, donde la forma de poder es la diferenciación desigual (quién pertenece a la comunidad y quién no); el del mercado, donde la forma de poder es el fetichismo de las mercancías; el de la ciudadanía, donde la forma de poder es la dominación vertical del Estado hacia los ciudadanos; y el mundial, donde la forma de poder es el intercambio desigual (Santos 2006:52-53).
} 
detenerme en cómo se presenta el problema de la resistencia en los movimientos teóricos antes analizados y cómo algunos movimientos sociales contemporáneos problematizan el tema.

Recordemos aquí un pasaje de Foucault (2009:116) arriba citado: "donde hay poder hay resistencia [...] ésta nunca está en posición de exterioridad respecto del poder”. A partir de pasajes como éste, Hardt y Negri (2012:71) han observado que "la idea de poder de Foucault siempre es doble". Por un lado, tenemos el poder como dominación que produce sujetos. Pero, por otro lado, hay otro poder que consiste en "una producción alternativa de subjetividad, que no sólo resiste al poder, sino que también busca autonomía respecto a éste" (Hardt y Negri 2012:71). Hardt y Negri distinguen estos dos tipos de poderes con los conceptos de "biopoder", para referirse al primero, y "biopolítica", para aludir al segundo. ${ }^{44}$ Esta distinción terminológica no se corresponde con la de Foucault, por lo que, como incluso sugieren los propios Hardt y Negri, prefiero emplear el término "resistencia" para referirme a esta segunda acepción del poder que ellos identifican en la analítica de Foucault.

Siguiendo la argumentación anterior, podemos apreciar que el poder en tanto resistencia comparte las características constitutivas del poder en Foucault: su concepción positiva-productiva, su relación con el saber y con el cuerpo, y su concepción no centrada en el Estado. Sin embargo, si seguimos más de cerca la argumentación de Hardt y Negri, veremos que su concepción de biopolítica acaso deba mucho más a la noción de "deseo" de Gilles Deleuze que al poder de Foucault. Quiero detenerme en esta cuestión, pues diversos análisis contemporáneos sobre poder y resistencia comparten, implícita o explícitamente, esta concepción.

En sus comentarios críticos a Vigilar y castigar y La voluntad de saber, Deleuze (1995:15) escribe sobre la "primacía del deseo sobre el poder", lo que quiere decir que primero existe el deseo (aunque nunca de manera natural, sino a través de

\footnotetext{
44 "Para marcar esta diferencia entre los dos 'poderes de vida', adoptamos una distinción terminológica, sugerida por los escritos de Foucault pero no usada coherentemente por éste, entre biopoder y biopolítica, donde el primero puede definirse (con cierta tosquedad) como poder sobre la vida y el segundo como el poder de la vida de resistir y determinar una producción alternativa de subjetividad" (Hardt y Negri 2012:72).
} 
"agenciamientos"45) que fluye en el campo social, el cual luego es codificado y (re)territorializado por los dispositivos de poder. Desde la antropología política procesualista, podemos pensar en cómo la vida social es un constante devenir que es sedimentado (aunque nunca del todo) por los procesos de regularización de las estructuras sociales (ver Moore 1978). Bajo esta lógica, y en crítica al marxismo, Deleuze y Guattari (2010:94) argumentan que un campo social "no se define tanto por sus conflictos y sus contradicciones como por las líneas de fuga [de deseo RL] que lo atraviesan". Deleuze (1995:19) interpreta estas líneas de fuga justamente como resistencia. En este orden de ideas, Hardt y Negri (2012:96) plantean que "no debemos pensar el poder como lo primordial y la resistencia como una reacción a aquél; por el contrario, por más paradójico que parezca, la resistencia es anterior al poder”.

Además de la primacía de la resistencia sobre el poder (según la lógica de Deleuze y Guattari y Hardt y Negri), hay otro elemento central en esta concepción de poder-resistencia-deseo: la idea de potentia. El concepto de deseo de Deleuze tiene una genealogía que se remonta principalmente a Spinoza (y su idea de potencia), y que también está fuertemente inspirada en la "voluntad de poder" de Nietzsche (ver Deleuze 2008). Así, el deseo tiene potencia y una voluntad de afirmación de la vida, es sumamente productivo. Y esta idea de poder-resistencia como potentia está muy presente en los análisis sobre movimientos sociales contemporáneos.

Por ejemplo, Dussel critica la concepción eurocéntrica del poder "como dominación" (2006:23) e interpreta el poder de la comunidad y de los movimientos sociales actuales como potentia, como "voluntad-de-vida", una "potencia que puede mover, arrastrar, impulsar" (2006:23). Dussel (2006:27) define la potentia como el "poder que tiene la comunidad como una facultad o capacidad que le es inherente a un

\footnotetext{
${ }^{45}$ El concepto de "agenciamiento" es central en la filosofía de Deleuze y Guattari y ha sido retomado en discusiones contemporáneas de antropología. Originalmente fue formulado en el primer libro conjunto de Deleuze y Guattari, El anti Edipo, como "máquinas deseantes", y fue reformulado en su libro intermedio sobre Kafka y, sobre todo, en el que muchos consideran es su obra cumbre, Mil mesetas. Para Deleuze y Guattari (2010:92), los agenciamientos son definidos según dos ejes: "Según un primer eje, horizontal, un agenciamiento incluye dos segmentos, uno de contenido, otro de expresión. Por un lado es agenciamiento maquínico de cuerpos, de acciones y de pasiones, mezcla de cuerpos que actúan los unos sobre los otros; por otro, agenciamiento colectivo de enunciación, de actos y de enunciados, transformaciones incorporales que se atribuyen a los cuerpos. Pero, según un eje vertical orientado, el agenciamiento tiene por un lado partes territoriales o reterritorializadas, que lo estabilizan, y por otro, máximos de desterritorialización que lo arrastran".
} 
pueblo en tanto última instancia de la soberanía, de la autoridad, de la gobernabilidad, de lo político". Es un poder en estado indeterminado, que se expresa de manera fenoménica como potestas, como poder institucionalizado y, según Dussel, comúnmente fetichizado y corrompido, aunque también puede manifestarse como "poder obedencial". De modo semejante, en su influyente libro Cambiar el mundo sin tomar el poder, John Holloway (2010:52) identifica el poder con el hacer: "El poder, en primer lugar, es simplemente eso: facultad, capacidad de hacer, la habilidad para hacer cosas. El hacer implica poder, poder-hacer [...] Poder, en este sentido, puede entenderse como 'poder-para', poderhacer". Así como, en Dussel, el poder como potentia se puede corromper en el poder como potestas fetichizado, para Holloway el poder-hacer también se puede fracturar (especialmente cuando el capital se apropia de la fuerza de trabajo) y fetichizar en el "poder-sobre". ${ }^{46}$ Ciertamente, tanto Dussel como Holloway están inspirados en Marx y no en Deleuze, pero, en ambos casos, el poder subyace como una potencia (como potentia o poder-hacer).

Ahora bien, ¿cómo funciona este poder como potencia, como resistencia? Para Holloway, la resistencia como revolución es una cuestión interna. El antagonismo interno en el poder entre poder-hacer y poder-sobre es la clave de la resistencia, pues muestra que la dominación (fetichizada en el poder-sobre, por ejemplo, el valor como trabajo objetivado o el capital) depende del poder-hacer (como la fuerza de trabajo).

En cambio, como ya he indicado arriba, para la colonialidad/modernidad y el giro decolonial la resistencia como descolonización se presenta tanto en términos de exterioridad (Dussel 2004) como de pensamiento fronterizo (Mignolo 2011). En el caso de Dussel, la exterioridad sirve como un principio ético para la liberación del Otro, de la víctima, del pobre negado por el sistema colonial moderno (se trata de la construcción de su proyecto de "trans-modernidad"). En cambio, Mignolo, con la idea de pensamiento de frontera, enfatiza los pensamientos que se mueven a lo largo de la diversidad de procesos históricos. Si la colonialidad del poder, del saber y del ser son ante todo órdenes

\footnotetext{
46 "El flujo social — escribe Holloway (2010:53) — se fractura cuando el hacer mismo se rompe. El hacercomo-proyección-más-allá se rompe cuando algunas personas se apropian de la proyección-más-allá del hacer (de la concepción) y comandan a otras personas para que ejecuten lo que ellas han concebido. El hacer se ha fragmentado en tanto el 'poderoso' concibe pero no ejecuta, mientras que los otros ejecutan pero no conciben. El hacer se rompe en la medida en que los 'poderosos' separan lo hecho respecto de los hacedores y se lo apropian".
} 
clasificatorios, los pensamientos fronterizos resultan anómalos y subversivos a dichos órdenes.

Hay que advertir que para todas estas elaboraciones sobre poder y resistencia han sido fundamentales los movimientos sociales contemporáneos, particularmente el Ejército Zapatista de Liberación Nacional (EZLN). En principio podemos convenir en que el EZLN plantea un concepto singular de poder, el "mandar obedeciendo", "un poder no coercitivo que está al servicio de las comunidades pueblerinas" (Amselle s.f.:6). Pero también podemos apreciar cómo cada analista se inspira en el movimiento y proyecta en él sus propias concepciones. Así, para Hardt y Negri, el EZLN es un emblema de la multitud y de su lucha por el común; para Dussel es la expresión de la potentia manifestada como poder obediencial, sobre la cual se basa un proyecto de transmodernidad; para Holloway es el poder-hacer autónomo que cambia al mundo sin tomar el Estado; para Mignolo un pensamiento fronterizo entre el marxismo, el tercermundismo y el indigenismo. Otro tanto se puede decir de los movimientos sociales en Bolivia y Ecuador, en sus luchas contra el neoliberalismo (como en contra de la privatización del agua y el gas en Bolivia) y en los proyectos del "Buen Vivir" como alternativas al desarrollo (Gudynas y Acosta 2011). ${ }^{47}$

Así como el EZLN y otros movimientos sociales han sido constitutivos en la gesta de concepciones sobre poder y resistencia, Boaventura de Sousa Santos ha escrito cómo el Foro Social Mundial (FSM) también ha ofrecido una renovación en nuestra forma de entender el poder. Por un lado, escribe Santos (2006:51), el FSM nos ofrece "una concepción más amplia de poder y de opresión", que va más allá de la opresión capitaltrabajo. Pero también ofrece otras concepciones sobre resistencia, fundamentalmente, las ideas de "articulación" y "traducción" de movimientos y la emergencia de una globalización contrahegemónica. En este sentido, la pregunta que plantea el FSM, según

\footnotetext{
${ }^{47}$ Amselle (s.f.:29) ha escrito que "El precepto de 'mandar obedeciendo' que el subcomandante Marcos pretende tomar de la tradición indígena de Chiapas, y que es retomado por Evo Morales, actual presidente de la República de Bolivia, ofrece semejanzas perturbadoras con la idea de Pierre Clastres según la cual la violencia en las sociedades primitivas tendría por función preservar su carácter indiviso y protegerlas así de la sobrevenida del Estado. La idea defendida por Silvia Rivera Cusicanqui y el Taller de Historia Oral Andina, según la cual el consenso y la ayuda mutua que prevalecen en las comunidades indígenas, y en particular en los ayllus bolivianos, serían los antídotos contra el veneno occidental representado por el Estado y que proporcionarían una solución alternativa a un poder de tipo coercitivo, va en el mismo sentido".
} 
Santos, no es cuál movimiento es el verdaderamente revolucionario, sino cómo cada uno de los movimientos es por definición incompleto y necesita de otros para transformar el mundo.

Por último, vale la pena hacer aunque sea una breve referencia a la teoría de James Scott (2000) sobre la resistencia. Comencé este capítulo diciendo con Sherry Ortner que podemos comprender el poder como un continuum que va desde la dominación hasta la resistencia. Así como la obra de Foucault ha sido acaso la más emblemática para entender la dominación (aunque, como vimos, también plantea el problema de la resistencia), el trabajo de Scott sobre las "armas de los débiles" y los "discursos ocultos" es uno de los más notables en el tema de la resistencia.

Scott plantea que en la interacción cotidiana entre dominantes y dominados, por ejemplo, un amo y su siervo, o un patrón y su empleado, encontramos lo que él denomina "guiones públicos", formas más o menos actuadas de comunicación en las que los dominados muestran respeto por los dominantes. Pero además de este guión público, sostiene Scott, también existen "guiones ocultos", tanto por parte de los dominantes como de los dominados, es decir, un conjunto de creencias, prácticas, valores y discursos que únicamente circulan en el ámbito privado de cada grupo social y que, generalmente, son críticos con respecto al otro grupo. Por ejemplo, los rumores, chismes y chistes de los empleados sobre sus patrones. Lo importante, nos dice Scott, es analizar estos guiones ocultos a partir de los cuales se ejerce la resistencia y que, en determinadas ocasiones, salen a la superficie. De acuerdo con los planteamientos de Scott, el poder es mucho menos invasivo de lo que podrían sugerir los análisis de Foucault y del poscolonialismo, ya que las personas dominadas entienden lo que está sucediendo e incluso son críticas de su dominación.

Me parece que, en todos los casos aquí expuestos, desde el deseo, la potencia, el poder-hacer, hasta los guiones ocultos, la resistencia es algo que subyace en el fluir de la vida social y que irrumpe y muestra su fuerza en determinados momentos. Sin embargo, ninguno de estos enfoques explica claramente por qué la resistencia emerge en determinados momentos. Tampoco nos dice mucho por qué una resistencia, como la de un esclavo que se rebela contra su amo, o la de un movimiento social en contra de la privatización de un recurso, puede ser más efectiva que otra. No nos responden de 
manera suficiente en qué se basa el poder de la resistencia más allá de la idea de una potencia implícita en los individuos (que, por cierto, también es dable a los dominantes). Me parece que para responder todas estas cuestiones, así como los aspectos problemáticos y críticos que señalé con respecto a la analítica de Foucault y el poscolonialismo, nos pueden ser muy útiles las elaboraciones teóricas sobre el poder formuladas por los antropólogos Eric R. Wolf y Richard N. Adams.

\section{Poder estructural y poder táctico}

Hacia el final de su vida, Eric Wolf $(2001 ; 2011)$ fue elaborando una propuesta teórica sobre el poder en donde distinguió cuatro modos del mismo: el primero es "el poder como el atributo de la persona, como potencia o capacidad" (2011:77; véase la discusión de arriba); el segundo es el poder "como la habilidad de un ego para imponerse sobre un alter, dentro de la acción social o en las relaciones interpersonales" (2011:77); el tercero es "el poder que controla los ambientes donde las personas interactúan con otras para mostrar sus potencialidades" (2011:77), es decir, se refiere específicamente a la teoría del poder social formulada por Richard N. Adams. A este modo del poder Wolf (2011:78) lo llamó “poder táctico o poder organizacional”. Por último, Wolf (2011:78) propuso el "poder estructural":

que no solamente opera en los escenarios o campos sino que además organiza a los mismos y especifica la distribución y dirección de los flujos de energía. Pienso que este tipo de poder es aquel que Marx esbozó al hablar del poder del capital para controlar y distribuir la fuerza de trabajo; éste es un antecedente de la noción de poder de Michel Foucault, quien lo asume como la habilidad "para estructurar el posible campo de acción de otros".

Wolf indica que, a diferencia de Foucault, quien "se interesó sobre todo en el poder para gobernar la conciencia" - aunque ya vimos que para Foucault el poder operaba, especialmente, sobre los cuerpos-, el concepto de poder estructural "estructura la economía política" (2011:78). Como señala el propio Wolf, la principal fuente del concepto es Marx y su noción de "relaciones sociales de producción", la cual "intenta enfatizar el poder para desplegar y distribuir la fuerza laboral" (2011:78). "La noción de poder estructural —escribe Wolf (2011:78) — es utilizada precisamente porque nos 
obliga a observar cómo las fuerzas del mundo hacen contacto sobre la gente que estudiamos".

Wolf se interesó principalmente en la relación existente entre el poder táctico y el poder estructural, aunque, lamentablemente, debido a su muerte, no pudo desarrollar teóricamente esta conexión (tampoco el vínculo, apenas anunciado, entre Marx y Foucault). Como es bien conocido, Wolf indagó sobre todo el poder estructural, especialmente en su magna obra Europa y la gente sin historia (Wolf 2005), así como en los casos del nacionalsocialismo, los aztecas y los kwakiutl (Wolf 2001). ${ }^{48}$ El objetivo de esta sección es, precisamente, explorar los nexos entre el poder táctico y el poder estructural. Para ello, comienzo exponiendo las principales tesis de la teoría del poder social de Adams para vincularlos con el poder estructural de Wolf. Sostengo, además, que estos elementos teóricos son sumamente fecundos para abordar los problemas planteados anteriormente en este capítulo.

Con base en elementos teóricos de la física (particularmente de la termodinámica), la biología, la antropología neoevolucionista de Leslie White, así como de material empírico (histórico y etnográfico) referente a Guatemala, Adams (1983) desarrolló una teoría del poder social que concibe a este último como la relación psicosocial entre unidades de operación ${ }^{49}$ basadas en el control de recursos energéticos significativos. ${ }^{50}$ Valgan algunas precisiones. La energía y los recursos energéticos se entienden en un sentido amplio, pues, como escribe Adams, "todo lo que existe en el ambiente es una forma de energía" (1983:28); lo central es que dichos recursos sean

\footnotetext{
${ }^{48}$ En realidad, en Europa, Wolf no empleó el concepto de "poder estructural", sino el de "modo de producción", con el cual enfatiza la relación entre el hombre y su ambiente y las relaciones que los hombres entablan entre sí para organizar la producción. Es a partir de dicho concepto que explora las maneras en que los fenómenos económico-políticos condicionan e interconectan diversos procesos sociales. Así, mientras que en Europa Wolf estudió los modos de producción basado en el parentesco, tributario y capitalista, más tarde distinguió tres modos diferentes de poder estructural: el basado en el parentesco, el tributario y el capitalista (2011:84). El concepto es el mismo.

49 "Una unidad de operación es un conjunto de actores que comparten un patrón de adaptación común con respecto a alguna porción del ambiente. El patrón implica la acción colectiva o coordinada y alguna ideología común que exprese metas o justificaciones" (Adams 1983: 71. Cursivas en el original).

${ }^{50}$ En palabras de Adams (1983:26): "El poder es aquel aspecto de las relaciones sociales que indica la igualdad relativa de los actores o unidades de operación; deriva del control relativo ejercido por cada actor o unidad sobre los elementos del ambiente que interesa a los participantes. Por lo tanto, es un fenómeno sociopsicológico, mientras que el control es un fenómeno físico". Quiero enfatizar, como lo hace Adams (1983:29), que los recursos energéticos deben ser culturalmente significativos para las unidades de operación: "las formas y los flujos de energía deben ser pertinentes para algún sistema de valor y significado, es decir, deben ser culturalmente reconocidos".
} 
culturalmente significativos, lo que quiere decir que su importancia varía culturalmente, no hay un recurso que, de manera natural, sea más importante que otro. Por ejemplo, en un entorno en donde el agua es el recurso más preciado, quienes controlen dicho recurso podrán ejercer un mayor poder social.

La distinción de Adams entre control y poder es clave para su teoría, ya que, mientras que el control es una cuestión física-material (se controla o no un recurso energético), el poder es un fenómeno psicosocial, en donde se entablan relaciones recíprocas y decisiones entre dos o más unidades de operación. Es en este último sentido que la distinción entre control y poder cobra importancia, pues la unidad de operación que controla el recurso puede tomar o no las decisiones sobre el mismo. Así, cuando la unidad de operación que ejerce el poder controla el recurso, ejerce poder independiente; cuando la unidad de operación que controla el recurso cede la toma de decisiones a otra unidad, esta última está ejerciendo poder dependiente (Adams 1983:58).

A partir de los elementos anteriores, Adams introduce dos conceptos centrales en su teoría: "niveles" y "dominios". Cuando el control que dos o más unidades de operación tienen sobre un recurso es equivalente, se encuentran en un mismo nivel; cuando no lo es, se encuentran en distintos niveles (Adams 1983:31). ${ }^{51}$ Estos conceptos sirven para estudiar el proceso de evolución del poder. Por ejemplo, a medida que las sociedades expanden su control sobre el ambiente se desarrollan diversos niveles; tal es el caso de la emergencia de los Estados nación como nuevos niveles de poder o de los organismos financieros internacionales. Estos dos conceptos nos son útiles entonces para entender el proceso de evolución de poder. Así, un incremento de niveles implica una concentración del poder, mientras que un aumento de dominios nos indica una diferenciación o división de los poderes (Adams 1983:109).

En este punto quiero recordar que el concepto de nivel tiene sus orígenes en la teoría de la evolución multilineal de Julian Steward (1973), quien desarrolló el concepto para analizar las sociedades complejas como entidades conformadas por distintos niveles

\footnotetext{
${ }^{51}$ En términos de Adams, "Un dominio es todo conjunto de relación donde haya dos o más actores o unidades de operación de poder relativo desigual frente a los demás. Si $A$ tiene sobre $B$ mayor poder que $B$ sobre $A$, decimos que $B$ se encuentra en el dominio de $A$. Sin embargo, el término dominio se vuelve útil en los casos de relaciones entre varias partes, cuando $A$ tiene dominio sobre varios subordinados" (p. 86). Puede haber un dominio unitario, cuando "hay sólo un superordinado inmediato por cada subordinado" (p. 86), o un dominio múltiple, cuando "el subordinado tiene acceso a través de dos o más canales" (p. 86).
} 
de integración sociocultural, de modo que había que estudiar a las comunidades en relación de integración con niveles más amplios, como el nacional. Siguiendo el programa de Steward del análisis de las sociedades complejas, Wolf (1956) formuló el concepto de broker o "intermediario", el cual establece relaciones de mediación entre diferentes niveles de integración de una sociedad, por ejemplo, entre la comunidad y las instituciones nacionales (Wolf 1956:1072). De acuerdo con Wolf, la función básica de los intermediarios es relacionar a individuos orientados hacia la comunidad con los individuos orientados hacia la nación. En este sentido, el intermediario es como Jano, pues mira hacia dos direcciones al mismo tiempo y debe lidiar con los conflictos que surjan entre los intereses de un nivel con los del otro, pero nunca suprimirlos, pues al hacerlo aboliría su propia utilidad como intermediario (Wolf 1956:1076).

Adams retomó el concepto de intermediario de Wolf para incluirlo en su teoría del poder social, ${ }^{52}$ e introdujo una distinción entre intermediario cultural e intermediario político. El intermediario cultural "se ocupa del cambio de los significados y los valores, o en el uso de ciertas formas culturales entre los miembros de algunas poblaciones, cuando estas innovaciones derivan de la cultura de otra población" (Adams 1983:67). Este tipo de intermediarios, como se verá más adelante, resulta crucial en sociedades pluriculturales como México. Por su parte, el intermediario político "ejerce poder en dos niveles, o dentro de dos dominios, y su poder en un nivel o dominio depende del éxito de sus operaciones en el otro" (Adams 1983: 67). Si bien diversos actores protagonistas de esta tesis conciben sus acciones en materia de reivindicaciones del Pueblo Maya como “culturales" y no como "políticas", considero que esta distinción es, en gran medida, de carácter heurístico, y que sólo se sostiene como tal si uno parcela la realidad en segmentos clasificados como "políticos", "culturales", "económicos", etc. En tanto que las actividades consideradas "culturales" impliquen control de recursos y órdenes clasificatorios simbólicos hegemónicos, son también prácticas políticas. Del mismo modo, en tanto que las acciones políticas están cargadas de significados y de sentido, son

52 Así, en la teoría de Adams (1983:66-67): "La intermediación incluye varias combinaciones de transferencias de poder. Básicamente consiste en una figura central, el intermediario, a quien una o más partes conceden, asignan o delegan poder. Este poder se usa para negociar con un tercero (que puede ser único o múltiple). El éxito de la negociación consiste en lograr que el tercero también conceda (o asigne o delegue) poder al intermediario, para que éste pueda negociar entonces con la primera parte. El intermediario eficaz es aquel que 1) termina la negociación con ventajas para sí mismo y 2) satisface a las otras partes de tal modo que estén dispuestas a volverlo a utilizar como intermediario". 
también culturales. Por lo tanto, emplearé en esta investigación el concepto de intermediario político-cultural o, simplemente, intermediario, para entender a varios de los actores clave de esta investigación.

Regresemos ahora a lo que Wolf llamó "poder estructural”. De acuerdo con Wolf, este tipo de poder es "ese que constriñe, que inhibe o promueve lo que la gente hace o no hace dentro de los escenarios que estudiamos", por lo tanto, indagarlo supone preguntar "cómo las fuerzas del mundo hacen contacto sobre la gente que estudiamos" (Wolf 2011:78). ${ }^{53}$ El poder estructural opera entonces en un nivel macro; tal como señala Wolf (2011:78), es "la dimensión que ha sido remarcada en los estudios sobre el imperialismo, dependencia o sistema-mundo".

Una de las preocupaciones centrales en la teorización de Wolf sobre el poder estructural fue la relación entre significados y poder. Su planteamiento es que cada modo de poder estructural ofrece elementos de conceptualización y categorización. De acuerdo con Wolf (2011:83), en este nivel:

el poder implicado en el significado apoya una versión de significación como verdad, fructífera o bella, contra otras posibilidades que pueden amenazar la verdad, exitosa o bellamente. Todas las culturas, sin embargo, esculpen significados e intentan establecerse contra posibles alternativas. En los asuntos humanos, las cosas podrían ser diferentes, y a menudo lo son.

Del mismo modo, para abordar el problema de la relación entre significados y poder, Wolf (2001) recuperó de Marx y Engels el concepto de ideología, y lo definió como "un complejo de ideas que se seleccionan para subrayar y representar un proyecto particular que instale, mantenga y aumente el poder en las relaciones sociales" (2001:81). Así, el poder estructural "implica una ideología que asigna distinciones entre las personas, basadas en las posiciones que éstas ocupan en la movilización de la mano de obra social" (Wolf 2001:32). Todo esto nos remite, nuevamente, al tema de los órdenes clasificatorios

\footnotetext{
${ }^{53}$ En este punto, quiero retomar la observación de Joao Biehl y Peter Locke (2010), cuando advierten que dos categorías centrales de la antropología sociocultural contemporánea que aluden a "eso que constriñe" son las de "violencia estructural", desarrollada desde la antropología inspirada en la economía política (P. Farmer [1996], P. Bourgois [2002], ver también Galtung [1969]), y la de "biopoder", formulada por Foucault. El concepto de "violencia estructural" alude a "la organización político-económica de la sociedad que impone condiciones de sufrimiento físico y emocional" (Bourgois 2002:75). Es un concepto que, sin duda, guarda mucha semejanza con el de poder estructural de Wolf.
} 
en relación con la división del trabajo, pero, a diferencia de la colonialidad del poder de Quijano, el criterio racial no es el único que está en juego.

Como último punto antes de pasar a la síntesis de este trabajo teórico, quiero detenerme en un aspecto más de la relación entre poder y significado, recordando, con Wolf (2005:6), que "todas las ciencias sociales, incluida la antropología, montan a horcajadas de dos realidades: la del mundo material y sus transformaciones humanas debidas a la técnica y la organización, y la de los esquemas de conocimiento organizado y operaciones simbólicas aprendidos y transmitidos entre los seres humanos" y que, una forma de abordar esta tensión, es "prestar mayor atención a las relaciones de poder que median entre la movilización del trabajo social en la sociedad y los esquemas mentales que definen quién hace qué en la división de ese trabajo" (Wolf 2005:6). Lo que quiero destacar es que las dimensiones materiales y simbólicas del poder (y de la realidad sociocultural toda) sólo son distinguibles analíticamente. ${ }^{54}$ En este orden de ideas, quiero señalar algunas de las maneras en que los elementos simbólicos y performativos están presentes en el fenómeno del poder. La famosa expresión “ $¡ E l$ rey ha muerto, viva el rey!" puede resultar ilustrativa al respecto.

\section{¡El rey ha muerto, viva el rey!}

Los antropólogos interesados en la política muy pronto descubrieron que el poder no puede sostenerse únicamente en la coerción o en la amenaza del uso de la fuerza, sino que también debe basarse en elementos simbólicos (Balandier 2006; Lewellen 1985). Los análisis sobre la "realeza divina" en diversas sociedades africanas son paradigmáticos al respecto. Por ejemplo, Evans-Pritchard (1987) estudió el caso de la realeza divina de los shilluk de Sudán, en donde encontramos la costumbre, que nos recuerda al bosque sagrado de Nemi (Frazer 1980), en la que el pueblo asesina a su rey. Para EvansPritchard, esta costumbre no es una supervivencia de un tiempo pasado, como lo podría interpretar un evolucionista, sino que la realeza divina es un símbolo de la sociedad. En un argumento por lo demás durkheimiano, Evans-Prithcard (1987:314) sostiene que en la realeza divina la sociedad se celebra a sí misma, se sacraliza; por lo tanto, el regicidio

\footnotetext{
${ }^{54}$ Considérese, por ejemplo, el énfasis de Foucault (2005) en la materialidad de los discursos, o, como subraya Wolf (2005:99), que el concepto de producción implica también intencionalidad, información y significado.
} 
resulta una suerte de ritual de rebelión que refuerza la estructura social shilluk (Díaz Cruz 2014).

En este orden de ideas, Clifford Geertz (1994) insistió en que todo centro de poder necesita símbolos, ritos, imágenes, historias, ceremonias, insignias, formalidades y accesorios, que no son meros adornos del poder, sino constitutivos de él. Para Geertz, esto no es algo privativo de las realezas europeas o "primitivas" como los shilluk, sino que se encuentra también en las sociedades modernas, desde el Führer hasta Mick Jagger. Así, la antropología ha desarrollado una perspectiva simbólica sobre el poder, que analiza, desde una tradición durkheimana, qué hay detrás de los símbolos del poder (por ejemplo, detrás de la realeza divina está la sociedad celebrándose a sí misma).

Por otra parte, la perspectiva performativa no se pregunta qué está detrás de los símbolos, o debajo de ellos, sino qué hacen los símbolos o qué efectos tienen (Turner 1999). De acuerdo con el filósofo inglés John L. Austin (1990), los enunciados performativos, a diferencia de los constatativos, no describen una acción, ellos mismos son acciones, hacen cosas. Por lo tanto, los enunciados performativos no se evalúan de acuerdo a un criterio de verdad, sino en términos de felicidad o infelicidad: es ante ciertas circunstancias que los enunciados performativos resultan felices y producen efectos. ${ }^{55} \mathrm{De}$ este modo, como ha enfatizado Rodrigo Díaz (2008), los performances crean presencias. En este orden de ideas, podemos retomar el concepto de "ceremonia definicional" formulado por la antropóloga Barbara Myerhoff (1986), el cual alude a los procesos de visibilización de los colectivos que han sido invisibilizados.

Ciertamente, la categoría "performance", como ha advertido Díaz (2008), es un término por lo demás inestable y sobre el cual se pueden encontrar diversas rutas de

\footnotetext{
${ }^{55}$ Bourdieu (2001) ha criticado a Austin el atribuir el poder de las palabras a "las propias palabras, es decir, allí donde este poder no está" (Bourdieu 2001:67). No obstante, Austin señala enfáticamente que no son las palabras en sí las que tienen poder performativo, sino que las circunstancias son constitutivas de su poder. Bourdieu repara luego en esto y contra-argumenta que "el análisis austiniano de las condiciones de validez y eficacia de los enunciados performativos resulta muy gris y pobre, sólo formalmente ingenioso" (Bourdieu 2001:73). En cambio, Bourdieu atribuye la eficacia de los performativos al poder simbólico: "El poder de las palabras reside en el hecho de que quien pronuncia no lo hace a título personal, ya que es sólo su 'portador': el portavoz autorizado sólo puede actuar por las palabras sobre otros agentes y, a través de su trabajo, sobre las cosas mismas, en la medida en que su palabra concentra el capital simbólico acumulado por el grupo que le ha otorgado ese mandato y de cuyo poder está investido" (Bourdieu 2001:69. Cursivas en el original).
} 
análisis. ${ }^{56}$ Indico sólo una más, que es el análisis de la performatividad, tal como ha sido trabajado desde la teoría queer por Judith Butler (2001), y que indaga cómo a través de prácticas repetitivas y estilizadas se producen categorías consideradas naturales, tales como "género" y "sexo". El análisis de la performatividad de Butler constituye también una potente crítica contra todo esencialismo o identidad basada en la idea de sustancia (ver Díaz Cruz 2009).

Para cerrar esta cuestión, cabe traer a colación que Vigilar y castigar de Foucault comienza, justamente, con un intento de regicidio en la Francia de mediados del siglo XVIII. Este pasaje le sirve a Foucault para indicar que el poder en la era contemporánea ya no se basa en la sacralidad del rey, sino en las disciplinas silenciosas que operan sobre los cuerpos. En palabras de Foucault (2005:220):

Nuestra sociedad no es la del espectáculo, sino de la vigilancia; bajo la superficie de las imágenes, se llega a los cuerpos en profundidad; detrás de la gran abstracción del cambio, se persigue el adiestramiento minucioso y concreto de las fuerzas útiles; los circuitos de la comunicación son los soportes de una acumulación y de una centralización del saber; el juego de los signos define los anclajes del poder; la hermosa totalidad del individuo no está amputada, reprimida, alterada por nuestro orden social, sino que el individuo se halla en él cuidadosamente fabricado, de acuerdo con toda una táctica de las fuerzas y de los cuerpos. Somos mucho menos griegos de lo que creemos. No estamos ni sobre las gradas ni sobre la escena, sino en la máquina panóptica, dominados por sus efectos de poder que prolongamos nosotros mismos, ya que somos uno de sus engranajes.

Sin embargo, y como nos recuerdan Geertz (1994) y Balandier (1994), estamos lejos de vivir en una sociedad desacralizada y desmitificada. Acaso la argumentación de Marx (1975) sobre el "fetichismo de la mercancía" sea una buena muestra de nuestras mistificaciones modernas. Más directa es la crítica de los Comaroff (2009) a la teleología de Foucault, quienes han planteado la existencia de una "metafísica del desorden" en Sudáfrica, donde el poder y la violencia aparecen sumamente dramatizados.

En síntesis, lo que la frase “¡El rey ha muerto, viva el rey!” nos plantea, es, por un lado, el problema de la relación entre elementos simbólicos y performativos del poder, y,

${ }^{56}$ Del mismo modo, como han observado diversos especialistas, se trata de un término sumamente inestable y controvertido, que se ubica y desplaza en varias tramas conceptuales científicas, humanísticas y artísticas (ver Bell 1998; Madison y Hamera 2006). 
por otro, el de la transición histórica de un régimen de poder a otro. Si Foucault está en lo cierto, ¿su concepto de disciplina sólo nos sirve para analizar el periodo histórico que él estudió?, ¿acaso atravesamos una era disciplinaria y ahora estamos en una postdisciplinaria donde los simbolismos y performances del poder cobran de nuevo importancia?, ¿cómo explicar el cambio de un régimen de poder a otro? Si Foucault no acierta del todo en su caracterización de la era disciplinaria, ¿cómo están presentes los símbolos y performances en el fenómeno del poder? Me parece que, si bien contamos con algunos trabajos sobre el cambio de una sociedad disciplinaria a una "sociedad de control" (Deleuze 1999), me parece que todas estas cuestiones son problemas empíricos que deben resolverse en la investigación. Considero que los planteamientos de Wolf y Adams, como ya he señalado, pueden ser muy útiles para ensayar respuestas a dichas interrogantes. Si bien la analítica del poder de Foucault tiene elementos muy fecundos, resulta cuestionable su aseveración relativa a que el poder se haya desacralizado. No obstante, la concepción positiva del poder, el papel del cuerpo y la microfísica no son excluyentes de los aspectos simbólicos y performativos del poder. De ahí que la expresión “iEl rey ha muerto, viva el rey!” ilustre — sobre todo en la segunda parte de la sentencia - que el poder siempre va a requerir de simbolizaciones y performatividad para ser ejercido. Para finalizar, presento una síntesis de la discusión teórica aquí expuesta y los planteamientos teóricos de esta investigación.

\section{Etnicidad y poder: planteamientos teóricos de esta investigación}

¿Qué tan compatibles o excluyentes son las concepciones de Adams, Wolf y Foucault sobre el poder?, ¿pueden integrarse en un solo marco teórico o provienen de perspectivas inconmensurables? Para responder a esta cuestión, podemos comenzar con las semejanzas entre dichos enfoques. Ninguno de los tres reduce el poder a lo formalmente político (por ejemplo, al Estado u otras instituciones formalmente políticas) y, aún más, desafían una concepción vertical del poder según la cual éste solo se ejerce de arriba hacia abajo. En segundo lugar, los tres consideran que el poder está presente en todas las relaciones sociales. Tercero, tanto Wolf como Foucault afirman que el poder no es algo externo a los fenómenos significativos y discursivos ("El poder nunca es externo a la significación", señala Wolf [2011:84]). Sin embargo, también encontramos importantes divergencias. 
Acaso una de las principales sea que, mientras para Adams y Wolf sí hay actores que ejercen poder (las unidades de operación), en el caso de Foucault no existe un actor que ejerza poder, éste es una estrategia, una táctica difusa, una serie de dispositivos y tecnologías; asimismo, mientras que en Adams y Wolf está presente la conciencia (los fenómenos intramentales de Adams, los significados culturales en Wolf), en Foucault desaparece el sujeto, no hay un sujeto con conciencia que ejerza el poder, sino, por el contrario, es el poder el que produce a los sujetos. En todo caso, Foucault no nos ofrece propiamente una teoría del poder, sino una analítica del poder para el estudio de los procesos de producción de sujetos; en este sentido, nos dice muy poco sobre cómo evoluciona el poder, cuestión central en los trabajos de Adams y Wolf, que sí nos pueden explicar el cambio de un régimen de poder a otro (ver Díaz Cruz 2014). Si bien los conceptos de poder estructural y poder táctico pudieran parecer más aptos para explicar distintos regímenes históricos de poder, considero que los elementos constitutivos del concepto de poder de Foucault (su concepción positiva, su relación con el saber y el cuerpo, así como su perspectiva no centrada en el estado) también nos pueden ser útiles para analizar el poder en diferentes contextos históricos.

¿Qué tan irreconciliables resultan, entonces, las propuestas de Adams, Wolf y Foucault?, ¿podríamos considerar al poder táctico, al poder estructural y al biopoder como distintas dimensiones del poder? En este punto puede ser útil recurrir a la distinción que establecieron Jean y John Comaroff entre dos modalidades del poder: por un lado, el modo "agencial" del poder, entendido como la habilidad relativa de los seres humanos de moldear la vida de los otros ejerciendo control sobre la producción, circulación y consumo de signos y objetos (en términos de Adams, los recursos energéticos significativos), y el modo "no agencial" del poder, que está inmerso en las formas de la vida cotidiana, en las formas que dirigen las prácticas y percepciones humanas en caminos convencionales (pensemos en el poder estructural o en el biopoder). Este modo no agencial, nos dicen los Comaroff, aparece como "natural" e "inefable", parece que está más allá de la agencia humana, satura la estética y la ética y sus efectos son internalizados (Comaroff y Comaroff 1992:28). En otro lugar, los Comaroff (1991:22-23) señalan que el poder no agencial se adscribe en ocasiones a fuerzas trascendentales y suprahistóricas, tales como dioses o ancestros, la naturaleza, la física, el instinto biológico, en otras palabras, a fuerzas que van más allá de la agencia del 
individuo. Así, tomando como ejemplo el capitalismo, los Comaroff ilustran el modo agencial del poder como las disputas por el control de los recursos (como los medios de producción) entre las clases sociales, y ejemplifican el modo no agencial en el fetichismo de la mercancía, que no sólo opera a nivel estructural sino que implica también una serie de creencias y discursos.

Del mismo modo, podemos sostener que las representaciones y discursos sobre la diferencia y la alteridad analizados por el poscolonialismo y que se producen en el marco del poder estructural y el biopoder son recursos que pueden ser controlados, tanto por los actores dominantes como por los dominados. En este sentido, una estrategia fundamental en la resistencia y en los proyectos de reivindicación son, justamente, la apropiación de representaciones y discursos sobre la diferencia y la alteridad.

Con estas ideas en el papel, paso ahora a exponer los planteamientos teóricos de esta investigación.

En primer lugar, podemos entender por etnicidad "la diferencia cultural movilizada por propósitos políticos, cuando los actores sociales, a través de procesos de acciones sociales, (re)crean narrativas de descendencia común para responder al ambiente social cambiante" (Malesevic 2004:4; cursivas de R.L1.). Me interesa destacar que, en esta definición, por un lado, la etnicidad aparece como un fenómeno inminentemente político y, por lo tanto, ligado al poder. Por otro lado, hay que recordar, con Weber, que no es el pasado común de facto el que interesa, sino la "creencia en un pasado común", "la creencia en el parentesco de origen, una creencia subjetiva en una procedencia común" (Weber 2014:524). ${ }^{57}$ Añadiría: no sólo narrativas sobre descendencia común, sino también de diferenciación con otros.

Este concepto de etnicidad está emparentado con la noción de "Pueblo" expuesta en la introducción de este trabajo y coincide con la concepción de Adams desarrollada en sus investigaciones sobre Guatemala y otros países centroamericanos. Para Adams (1995), la etnicidad consiste en la manera en que las personas se organizan socialmente en términos de su ascendencia y "ratifica una continuidad de formas culturales seleccionadas, que significan o simbolizan la continuidad biológica y cultural con el

\footnotetext{
${ }^{57} \mathrm{Y}$ Weber continúa, con una vocación muy à la the invention of tradition, apreciando que esta creencia se basa "a menudo [en] antepasados comunes inventados" (Weber 2014:524).
} 
pasado" (Adams 1995:38). En el contexto de la sociedad contemporánea, por lo demás desigual, la etnicidad es una forma de obtener "respeto propio y orgullo en un mundo que les niega [a los que portan la identidad étnica] bienes y servicios" (Adams 1995:215).

En segundo lugar, la etnicidad no es un fenómeno dado, natural, ahistórico, una propiedad o atributo que los grupos simplemente, por el hecho de existir, poseen. Como han escrito los Comaroff, la etnicidad siempre tiene su origen en fuerzas históricas específicas, al mismo tiempo estructurales y culturales (Comaroff y Comaroff 1992:112). Podemos pensar aquí, por ejemplo, en cómo en una determinada sociedad en un periodo histórico específico opera la distribución de recursos entre distintos grupos y el funcionamiento de las clasificaciones simbólicas y discursos sobre los mismos. Pero "si bien la etnicidad es producto de procesos históricos específicos-continúan los Comaroff (1992:124) — tiende a adoptar el aspecto 'natural' de una fuerza autónoma, un 'principio' capaz de determinar el curso de la vida social". 58 Para entender estas fuerzas históricas y estructurales, los conceptos de "poder estructural", "poder táctico", "biopoder" y "colonialidad del poder" me son útiles para investigar el poder entendido como la producción y distribución de recursos entre colectivos culturales así como de los órdenes clasificatorios simbólicos que categorizan a dichos colectivos culturales. El poder no existe en abstracto, como una sustancia, sino que se expresa en campos, arenas, procesos políticos y relaciones, en las cuales son distinguibles elementos de larga duración (como la persistente inferiorización de la población clasificada como “india"), así como de más reciente duración, sobre todo asociados a los procesos de reestructuración neoliberal en Yucatán. Del mismo modo, el poder puede entenderse en articulación con diversas escalas o niveles, desde los más macroscópicos (el sistema colonial o la economía mundial), como más microscópico (las relaciones cotidianas entre actores de distinta identidad cultural y/o étnica). En el análisis del poder veremos que el orden clasificatorio interétnico en Yucatán no es tan sencillo como lo pueden sugerir las categorías "indio", "negro", "blanco" y "mestizo", sino que encontramos diversas "anomalías" que

\footnotetext{
${ }^{58}$ En este sentido, como ha escrito J.L. Comaroff (1996:166), "nuestra tarea como científicos sociales, en consecuencia, es establecer cómo se percibe la realidad de toda identidad, cómo se esencializa su esencia, cómo llegan a ser objetivadas sus cualidades objetivas". Desde luego, este ejercicio intelectual no es privativo al análisis de las identidades étnicas, sino que se trata de una operación epistémica muy presente en la historia de la antropología sociocultural (ver J.L. Comaroff 2010). Y me parece que el análisis performativo, como he señalado, constituye una ruta privilegiada para comprender cómo se "esencializan las esencias".
} 
complejizan las clasificaciones. Por último, mostraré que las representaciones y discursos sobre la alteridad y diferencia, estudiados por el poscolonialismo, son elementos constitutivos de dicho sistema.

No basta, sin embargo, con distinguir entre dos dimensiones del poder -el control de recursos significativos y los sistemas clasificatorios hegemónicos-, también hay que analizar la manera en que ambas se relacionan. Argumento que los sistemas clasificatorios hegemónicos son claves en el proceso del control de recursos, desde la definición de cuáles son los recursos significativos —no olvidemos que son culturalmente definidos como tales-, hasta las formas de acceder a ellos y controlarlos. Del mismo modo, insisto en que los recursos a controlar no son únicamente materiales, sino también pueden ser "simbólicos". En el caso de la etnicidad, el "respeto" y el "reconocimiento" son recursos fundamentales a controlar. Al respecto, tengamos en cuenta los notables trabajos de los filósofos Charles Taylor (2009) y Axel Honneth (1997 y 2007), ambos inspirados en Hegel, sobre el multiculturalismo y las "luchas por el reconocimiento".

De acuerdo con Taylor (2009:54), "el falso reconocimiento o la falta de reconocimiento pueden causar daño, pueden ser una forma de opresión que subyugue a alguien en un modo de ser falso, deformado y reducido", por lo que "el reconocimiento debido no sólo es una cortesía que debemos a los demás: es una necesidad humana vital" (2009:54-55). Por su parte, Honneth (1997 y 2007), heredero de la teoría crítica de la Escuela de Frankfurt, ubica las luchas por el reconocimiento como crítica a las situaciones de humillación, desprecio e injusticia que surgen de un falso reconocimiento o de procesos de "reificación". En el contexto de la antropología mexicana, Guillermo Bonfil (1981 y 1987) también ha destacado la gravedad de la falta de reconocimiento o del falso reconocimiento - de la "negación"- de los pueblos indígenas y la importancia de su reconocimiento como "civilización" o "alternativa civilizatoria". Así, los cambios en la distribución del control de recursos y de los sistemas clasificatorios se pueden combinar de diversas formas dando lugar a múltiples procesos.

En tercer lugar quiero insistir en que la etnicidad no es lo mismo que la cultura o que la diferencia cultural. El reconocer que un determinado grupo sea culturalmente diferente a otro no implica en sí mismo la existencia de la etnicidad. Ésta sólo emergerá 
cuando la diferencia cultural sea "activa, movilizada y dinámica, no sólo mera diferencia" (Malesevic 2004:4). Es decir, cuando la diferencia cultural puede operar como un recurso culturalmente significativo (Adams). Recordemos, una vez más, a Barth: una cultura no constituye necesariamente un grupo étnico (1976:9). Nuestro análisis no debe dedicarse a demostrar el "hecho de compartir una cultura común" (1976:12), "no podemos suponer una simple relación de paridad entre unidades étnicas y las similitudes y diferencias culturales” (1976:15). Como ha escrito Luis Vázquez León (1992:13), “algunos grupos indígenas pueden ser también grupos étnicos, pero [...] no todos son necesariamente por el solo hecho de ser culturalmente diferentes". En breve, el foco no es el contenido cultural. ${ }^{59}$ Como argumentó Barth, los grupos étnicos son "una forma de organización social", cuyo rasgo crítico es "la característica de autoadscripción y adscripción por otros" (1976:15), el foco es "el límite étnico que define al grupo y no el contenido cultural que encierra" (1976:17). Podríamos decir, con los Comaroff (1992), que lo primordial de la etnicidad no es el contenido cultural, sino los sistemas de clasificación que supone. Esto en virtud de que, como ha escrito Claude Lévi-Strauss, la exigencia de los órdenes clasificatorios "se encuentra en la base del pensamiento primitivo, pero sólo en cuanto se encuentra en la base de todo pensamiento" (Lévi-Strauss 1972:25). Al igual que el totemismo, argumentan los Comaroff, la etnicidad es un sistema clasificatorio, sólo que, a diferencia del primero, la materia de clasificación son las diferencias culturales en contextos de relaciones de desigualdad (Comaroff y Comaroff 1992:116118). Entonces, no me centro en el análisis de la cultura, sino en campos, procesos políticos y relaciones de poder. ${ }^{60}$ Como ha observado Malesevic, el solo contacto entre grupos culturalmente distintos no es condición suficiente (aunque sí necesaria) para la emergencia de la etnicidad. Tampoco podemos pasar por alto, como insistió el antropólogo brasileño Roberto Cardoso de Oliveira (1963) con su teoría de la "fricción

\footnotetext{
${ }^{59}$ Soy insistente en este punto pues, como mostraré más adelante, muchas investigaciones sobre la identidad étnica de los mayas defienden la existencia de dicha identidad a partir del postulado de que los mayas comparten una cultura común. Una crítica al abordaje de los grupos étnicos como grupos culturales puede encontrarse también en A.L. Epstein (1978).

${ }^{60}$ El análisis del antropólogo Roberto Varela (2006) sobre la participación política en comunidades campesinas de Morelos me ha resultado inspirador en este punto, pues la explica no en función de una determinada "cultura política", sino de acuerdo a la evolución de estructuras de poder. Reconozco también que las sospechas hacia el análisis culturalista tienen larga data en la historia de la antropología, al menos desde los días de Radcliffe-Brown (1974), Leach (1976), hasta, más recientemente, Adam Kuper (2001).
} 
étnica”, que, en América Latina, el contacto en el que entran los grupos indígenas con otros grupos poblacionales se suele dar en condiciones de desigualdad cuando no netamente "coloniales"; son situaciones de contacto en el que el grupo superior "niega" al grupo minorizado. Por lo tanto hay que preguntarnos, ¿ante qué condiciones la diferencia cultural es movilizada por distintos fines?, ¿ante qué condiciones se gestan las reivindicaciones del Pueblo Maya?

Como la etnicidad y el contacto entre grupos culturalmente distintos no tienen lugar en el vacío histórico y geográfico, vale la pena presentar unas notas en torno al problema de la etnicidad en América Latina y su relación con el poder, tal como aquí ha sido desarrollado. Debido a que existen numerosos estudios sobre el tema, me limitaré a exponer unos puntos referentes a la relación entre etnicidad y poder.

En su influyente estudio sobre las organizaciones y movimientos indígenas en América Latina desde la década de los setenta, titulado Utopía y revolución, Guillermo Bonfil (1981) observó que un elemento central en la emergencia de los movimientos indígenas fueron las consecuencias no advertidas de las políticas indigenistas de integración, las cuales:

[en sus] intentos por capacitar a individuos de las propias comunidades indias para que actúen como agentes de cambio en el marco de la política indigenista, permite que se forme un sector intermediario de origen indio (maestros, promotores, extensionistas, etc.), el cual queda en posibilidad de instituir sus propias prácticas y crear espacios institucionales para ese grupo (definidos en términos étnicos). Esa tendencia se consolida en la medida en que se obstruyen los canales de ascenso social en la esfera de la sociedad dominante y facilita la integración de una élite india dispuesta a plantear demandas políticas étnicas (Bonfil 1981:33).

Por su parte, José Bengoa (2000), en su libro La emergencia indígena en América Latina, explica cómo los fenómenos de globalización, el fin de la Guerra Fría y los procesos acelerados de modernización fueron claves en la emergencia de los movimientos indígenas en la región. En sus palabras:

$\mathrm{Al}$ abandonar el Estado su función integradora se producen espacios nuevos para que los grupos se diferencien al interior de las sociedades. Durante el período nacional populista, por ejemplo, los indígenas tenían que aparecer como campesinos y ciudadanos del país. 
Al romperse estos lazos, los indígenas tienen más facilidades para aparecer como indígenas, como ciudadanos diferentes, porque en la práctica se ven a sí mismos cada vez más excluidos. La ruptura del concepto nacional populista de ciudadanía es fundamental para comprender la emergencia étnica en América Latina en los años noventa. Es como consecuencia de estas rupturas que comienza a surgir, tímidamente por cierto, la demanda por "los derechos civiles indígenas", la demanda por una "doble ciudadanía", nacional y étnica. La exclusión indígena permite que emerja con más fuerza la conciencia indígena (Bengoa 2000:48-49).

Tomando en consideración la doble dimensión del poder aquí abordada, Víctor Toledo (2005) ha observado que los movimientos indígenas han sido eficaces en la dimensión simbólica, particularmente en la construcción social de problemas, el planteamiento de demandas, la elaboración de discursos, la creación de marcos de sentido y la emergencia de valores (el valor de la diferencia, la interculturalidad, la autonomía, etc.). Sin embargo, en la toma de decisiones, formulación de políticas propias y en su implementación, señala que el desempeño de los movimientos indígenas ha sido aún insuficiente.

La conocida revisión sobre movimientos indígenas latinoamericanos entre 1992 y 2004 realizada por Jean Jackson y Kay Warren (2005) coincide en varios aspectos con la de Toledo, pues destacan cómo algunos movimientos indígenas (especialmente en Ecuador, Bolivia y en Chiapas) han sido exitosos en las múltiples resignificaciones de la “indigeneidad", en la subversión de dicotomías como las de tradicional-moderno, urbanorural, auténtico-inauténtico, pues los indígenas son cada vez más transnacionales, urbanos, proletarios, bilingües y trilingües, cruzando muchas fronteras. Asimismo, entre los logros de los movimientos indígenas también destacan la transformación profunda en la visión de los estados latinoamericanos como naciones homogéneas; ahora se han establecido el derecho a la diferencia, la autonomía y autodeterminación y el reconocimiento de las poblaciones indígenas no como "minorías", sino como "pueblos". Por último, Jackson y Warren convienen en el hecho de que si los movimientos indígenas quieren tener éxito necesitan "ejecturar" [perform] su diferencia indígena, y que las performances de los movimientos estén destinadas a distintas audiencias.

En un tono similar al de Jackson y Warren, Marisol de la Cadena y Orin Starn (2009), dos de los antropólogos más reconocidos en nuestros días que trabajan sobre 
movimientos indígenas contemporáneos en América Latina, abordan el problema de la "indigeneidad" como una "formación discursiva" que abarca a los indígenas pero también a los no indígenas. De la Cadena y Starn afirman que los intelectuales indígenas han jugado un papel clave en la construcción de nuevas concepciones de indigeneidad, pero en dichas concepciones también han jugado un papel notable académicos, políticos y otros actores. Otros estudios notables sobre indigeneidad (como el de Goodale 2006), también abordan la indigeneidad como una formación discursiva.

El trabajo de Warren (1998) sobre el activismo pan-Maya en Guatemala y sus críticos enfatiza también los aspectos simbólicos o discursivos del movimiento indígena. Warren argumenta que los intelectuales y profesionistas urbanos mayas que reivindican la lengua maya son "héroes contrahegemónicos" (concepto que retoma de Florencia Mallon) y han desafiado la herencia colonial de Guatemala y que, frente a las diversas críticas que se les han hecho, el movimiento pan-maya ha tenido importantes logros, como mostrar que existen diversas formas de ser maya (no sólo campesinos pobres o trabajadores explotados); ha cuestionado la ilusión de una cultura nacional homogénea y hegemónica, construida a través del monopolio de las escuelas, iglesias, medios de comunicación y estructuras políticas; ha logrado incorporar nuevas generaciones de profesionistas mayas, maestros de escuela primaria, consejos de ancianos, trabajadores, a la comunidad discursiva pan-maya; ha puesto en circulación ideas innovadoras, como el multiculturalismo, la revitalización de la cultura y lengua maya, los derechos culturales; $\mathrm{y}$, sobre todo, afirma Warren, ha gestado nuevos lenguajes para formular las políticas identitarias, entender la desigualdad y organizarse a través de comunidades.

Las conclusiones de Warren contrastan con los hallazgos de James Mackenzie (2010) en su estudio sobre el movimiento pan-Maya guatemalteco en la comunidad de Xecul. Mackenzie argumenta que una de las fuentes más fuertes de poder del activismo pan-maya es su constitución como una red o como una serie de redes articuladas, pero que no necesariamente alcanza a las comunidades $\mathrm{y}$, de hecho, no requiere de una relación con las bases para ser efectivas. Dos características de estas redes pan-mayas son el énfasis en el orgullo étnico como "mayas" (y no como "indígenas" u otras categorías), y el incremento en el rol del ladino como el otro étnico. A pesar de estos logros, Mackenzie advierte dos limitaciones del movimiento pan-maya: el fracaso para ratificar 
los acuerdos de la Consulta Popular y la derrota de Rigoberta Menchú como candidata presidencial.

Mackenzie reconoce que la emergencia del pan-mayanismo es una novedad histórica, una nueva forma de identidad y de agencia, con una forma de poder ejercida en redes, pero que difiere de la forma ejercida en las comunidades y que, por lo mismo, no ha logrado transformarse en un movimiento de bases. Del mismo modo, señala Mackenzie, al construir al ladino como el otro no siempre se promueven los espacios de diálogo intercultural. Así, las transformaciones discursivas no son suficientes para lograr una movilización de bases y resultados políticos de mayor alcance.

En este punto, las ideas sobre poder y resistencia como potencia me resultan poco útiles para explicar las reivindicaciones del Pueblo Maya. Más bien, centro mi análisis en los actores (las unidades de operación de Adams), los recursos que controlan, cómo se apropian de representaciones y discursos sobre alteridad y diferencia, y cómo manifiestan de manera simbólica y performativa dichas reivindicaciones. Mucho menos entiendo la resistencia y reivindicación étnica como una sustancia cultural que emerge en determinados momentos. Retomando el análisis de la performatividad, creo que es justo a través de prácticas performativas que se constituye la idea de un "Pueblo Maya". En los capítulos cuarto, quinto y sexto veremos cómo determinados actores autoidentificados como mayas controlan una serie de recursos culturalmente significativos y cómo se apropian de las ideas de "Pueblo Maya", de historias, de procesos legales y tecnologías para reivindicar al Pueblo Maya. Con todas estas prácticas, los actores que reivindican al Pueblo Maya sin duda están transformando los órdenes clasificatorios coloniales (en términos del poscolonialismo, podemos decir que están gestando procesos decoloniales). No obstante, no podemos entender estas reivindicaciones étnicas únicamente como prácticas que transforman órdenes clasificatorios, sino que también hay que entender cómo se transforma el sistema de poder interétnico a partir de la distribución del control de recursos.

Lo anterior nos lleva a lo que al inicio de este capítulo caractericé como una simetría en la explicación de la dominación y la resistencia. A partir de los elementos teóricos aquí presentados, considero que tanto la dominación como la resistencia pueden 
ser explicadas a partir de la indagación de los recursos que están siendo controlados y los órdenes clasificatorios simbólicos y performances puestos en juego.

Por último, reconozco que ante posturas como la presente, antropólogos como A.L. Epstein (1978) podrían criticar que conceptualizar la etnicidad en términos de poder puede ser un reduccionismo semejante al de concebir a los grupos étnicos como grupos culturales. En un caso, un reduccionismo culturalista, en otro, uno político. Desde luego, Epstein esgrime sus críticas en contra de quienes conciben lo político como una lucha por el poder que se pelea en términos de un frío cálculo racional, dejando de lado el componente afectivo del comportamiento étnico. Por mi parte, considero que no hay razón para sostener que la política, lo político, excluya elementos afectivos. Como ya he señalado, diversos estudios antropológicos sobre el poder (Balandier 1994; Geertz 1994) han mostrado cómo lo simbólico, lo afectivo y lo comunicativo son elementos constitutivos del poder. Asimismo, podemos recordar, una vez más, a Weber: las reivindicaciones del pueblo maya pueden ser al mismo tiempo acciones racionales con arreglo a fines (controlar y movilizar recursos), acciones racionales con arreglo a valores (la solidaridad con la población maya hablante y otras poblaciones indígenas), acciones tradicionales (heredadas de generaciones pasadas) y afectivas (las emociones en juego, como la vergüenza o el orgullo étnico). Ese es un asunto que hay que indagar y que no se puede dar por presupuesto. El trabajo teórico sobre el poder que aquí he presentado me parece que puede ofrecer herramientas para ello. 


\section{SEGUNDA PARTE. \\ LA MAYANIZACIÓN DE LOS MESTIZOS YUCATECOS: \\ EMERGENCIA DE LA ETNICIDAD MAYA EN YUCATÁN}




\section{Continuidades y discontinuidades entre mayas antiguos y mayas contemporáneos}

\section{Sobre la tesis de la continuidad y la tesis de la discontinuidad}

Si bien no hay consenso sobre lo que es la etnicidad (sobre lo que se basa o lo que la define), como vimos en el capítulo anterior, un elemento crítico que suele aparecer en muchos estudios, al menos desde Max Weber, es el de la ascendencia. Ya sea una ascendencia real o imaginada, un grupo étnico suele definirse no sólo a partir de trazar fronteras con otros, sino sobre todo reconociéndose como los descendientes de un grupo que habitaba el mismo territorio desde tiempos inmemoriales. Por lo tanto, un aspecto central en la cuestión de ser o no ser maya, es la de si los individuos que se definen como mayas son o no descendientes de los antiguos mayas, de aquellos "grandes arquitectos mayas" (Bartolomé 1988:30). Y este es un asunto por lo demás complejo, pues encontramos diversas posiciones, algunas de ellas ferozmente encontradas entre sí; distintas posturas no sólo al interior de los grupos indígenas, sino también entre intelectuales, viajeros, antropólogos, foráneos y locales.

En este capítulo analizaré algunos de los órdenes clasificatorios y discursos hegemónicos que han definido lo "maya". También estudiaré la forma en que algunos actores responden y se apropian de dichos órdenes y discursos y cómo estos se han convertido en un recurso fundamental a ser controlado en el proceso de reivindicaciones del Pueblo Maya.

Debo aclarar que mi interés en este capítulo radica no solamente en cómo se ha inventado lo maya (ver Castañeda 1996), sino en cómo, a partir de la discusión sobre la continuidad y discontinuidad, se construye lo maya pero también lo no maya, cuáles son las 
relaciones entre ambas entidades, cómo se interceptan, cómo se emplean, qué poderes y saberes implican, cómo se ha llegado al momento actual en que la tesis de la continuidad funciona como un recurso significativo a ser controlado por aquellos que reivindican al Pueblo Maya.

Así, en este capítulo exploraré dos tesis presentes en la historia de la discusión sobre la descendencia entre los mayas antiguos y contemporáneos. Por un lado, lo que llamaré la tesis de la continuidad, que sostiene que los mayas contemporáneos son descendientes de los mayas antiguos; por otro, la tesis de la discontinuidad, que afirma que los mayas contemporáneos no son descendientes de los mayas antiguos. Argumento que, en un plano meramente abstracto y teórico, ninguna de las tesis implica por sí misma juicios de valor. No obstante, históricamente, ambas tesis han estado saturadas de valoraciones, tanto positivas como negativas, y se han enmarcado en distintas tramas conceptuales y relaciones de saber y poder.

Resulta imposible analizar de manera exhaustiva todas las discusiones en las cuales las tesis de la continuidad y la discontinuidad han estado implicadas. Por lo tanto, me detendré solamente en tres momentos. El primero es el de la discusión entre el viajero norteamericano John Lloyd Stephens, quien visitó Yucatán a mediados del siglo XIX, y el intelectual y escritor yucateco Justo Sierra O'Reilly. Esta discusión resulta particularmente importante ya que fue Stephens quien dio a conocer la civilización maya al mundo europeo y norteamericano, si bien todavía no se empleaba el término "maya" para referirse a dicha población. El segundo momento corresponde al del nacimiento de la antropología como ciencia en Yucatán. Específicamente me refiero al proyecto de antropología social dirigido por el antropólogo norteamericano Robert Redfield en el marco de un proyecto más amplio de la Carnegie Institution of Washington, así como al proyecto de antropología integral del antropólogo y filólogo yucateco Alfredo Barrera Vásquez. Ambos compartieron en mayor o menor medida la tesis de la discontinuidad y sostuvieron que los indígenas contemporáneos no tenían cultura maya. Ésta, desde luego, ya había sido "inventada" por los arqueólogos mayistas. Y de nuevo encontramos respuestas contrarias. Intelectuales como José Díaz Bolio se esmeraron en defender la tesis de la continuidad. El tercer y último momento es el de ciertas posiciones hegemónicas en la antropología social contemporánea amén de ciertos movimientos de reivindicación étnica. Me detengo en el trabajo del antropólogo de origen 
argentino Miguel Alberto Bartolomé, quien ha defendido la tesis de la continuidad, argumentando que los indígenas mayas actuales portan una tradición milenaria que se remonta a tiempos prehispánicos. Ésta es una posición comúnmente aceptada por los antropólogos de finales del siglo XX e inicios del XXI.

Quiero destacar por último dos cuestiones. La primera es que parto del supuesto de que estas discusiones han sido un marco de referencia para que diversos sectores poblacionales, entre ellos los indígenas, establezcan relaciones de continuidad o discontinuidad entre los indígenas contemporáneos y los mayas antiguos. Las pruebas de continuidad o de discontinuidad no han sido las mismas a través del tiempo, y su variación nos puede ayudar a entender en qué términos se establece la continuidad étnica entre mayas contemporáneos y antiguos. Lo que nos lleva directamente a la segunda cuestión. En estas discusiones no sólo se ha abordado el tema de la continuidad o discontinuidad, sino también, ya sea de manera directa o indirecta, se toca el tema de qué es lo maya. Estas discusiones, por lo tanto, son cruciales en los procesos de etno-génesis maya.

\section{Del problema del origen al problema de la ascendencia}

Con un enfático marco conceptual que podríamos caracterizar de "naturalista", los primeros en describir a las poblaciones naturales del Nuevo Mundo se preguntaron por el origen y estatuto ontológico de dichos pobladores (¿de dónde provenían?, ¿tenían alma?). No se trataba solamente de una cuestión teológica, también implicaba una posición política: de acuerdo al estatuto ontológico de los indios se desplegaría una serie de acciones sobre ellos.

El problema del origen de las poblaciones nativas de América fue transmutando con el correr de los siglos: de ser un problema fundamentalmente teológico, pasó a ser también uno de la curiosidad científica y romántica de los siglos XVIII y XIX, aunque no siempre perdió del todo su carácter teológico (Huddleston 1967:12). Por ejemplo, el primer francés en dar a conocer las ruinas de Uxmal a Europa y los Estados Unidos, Jean Frédéric Waldeck, siguió la tradición (marcadamente orientalista — Said [2004]) de considerar que los antiguos pobladores de Uxmal provenían de las tribus perdidas de Israel (ver Depetris 2009a, 2009b y 2010; Depetris y España 2010).

Sin embargo, hacia mediados del siglo XIX, al problema del origen se sumó otra fascinante e ignota pregunta: ¿eran los constructores de pirámides los ancestros de los 
actuales habitantes de la América? No es que nunca se hubiera planteado la interrogante. En Yucatán, por ejemplo, fray Diego López de Cogolludo formuló la cuestión, pero escribió con franqueza que no había respuesta previsible: no hay "tradiciones ciertas entre los indios de los primeros pobladores de quien descienden" [...] "Quiénes fuesen [los constructores de los edificios en ruinas] se ignora, ni los indios tienen tradición de ello" (López Cogolludo 1954 [1658]:313, 325). Acaso la impresión dominante era que, como escribió el oidor de la Audiencia de Guatemala Diego García de Palacio (1983 [1576]:89) a propósito de las ruinas de Copán, sus contemporáneos naturales no pudieron haber edificado dichos remanentes: "están unas ruinas y vestigios de gran poblazón —escribió García de Palacio - y de soberbios edificios y tales, que parece que en ningún tiempo pudo haber en tan bárbaro ingenio, como tienen los naturales de aquella provincia, edificios de tanta arte y suntuosidad". Imposible que los indios naturales de "bárbaro ingenio" hubieran edificado "soberbios" edificios como los de Copán.

Pero el problema del origen y el de la ascendencia, si bien están estrechamente relacionados, son independientes entre sí. Al menos lo eran para John Stephens y Justo Sierra, a quienes el problema del origen les resultaba lo bastante oscuro, sin falta de pruebas analizables, como para ser estudiado científicamente. En cambio, para la pregunta por la ascendencia se contaba con pruebas, ya sea a favor o en contra, que se podían estudiar de manera "científica". Esto justo en un momento en el que, como han argumentado Gordon Willey y Jeremy Sabloff (1974:64), comienza el periodo “clasificatorio-descriptivo" de la ciencia arqueológica, si bien desde los mismos albores de la modernidad, los principios de precisión, medida, exactitud y rigor ya eran exigencia común en otros ámbitos de la ciencia (ver Koyré 1982; Le Breton 1995). Me parece entonces que fue el norteamericano John Lloyd Stephens quien en sus voluminosos libros Incidentes de viaje a América Central, Chiapas y Yucatán, de 1841, e Incidentes de Viaje a Yucatán, de 1843, planteó como tal el acalorado debate en torno a si los indios del siglo XIX eran o no los descendientes de los constructores de los magníficos edificios en ruinas que sus libros bien dieron a conocer a la civilización noratlántica. Stephens sostuvo la tesis de la continuidad, es decir, que los nativos de la América que él visitó eran los descendientes de los antiguos pobladores de la región, que en otros tiempos construyeron los edificios entonces en ruinas. Era una tesis que desafiaba buena parte del saber y sentido 
común de la época, pero provocó la particular molestia de uno de los intelectuales yucatecos más notables del momento, el distinguido Dr. don Justo Sierra O'Reilly, ferviente defensor de la tesis de la discontinuidad. ¿Cómo entender esta discusión?, ¿en qué términos se dio?, ¿cuáles fueron sus implicaciones? Veamos.

Ciertamente, John Lloyd Stephens era un hombre singular. "Abogado de profesión, diplomático por comodidad, viajero por inclinación y arqueólogo por elección" (Von Hagen 1947:126), nació en Nueva Jersey en 1805 pero creció desde muy temprana edad en la cada vez más cosmopolita ciudad de Nueva York, donde recibió una formación clásica, latinista, para después estudiar derecho. A los 19 años leyó una carta de su tía Helena, la cual "estaba llena de detalles sobre la vida en el oeste [de los Estados Unidos]: indios, llanuras, búfalos, cabañas de troncos, las chontes flotantes en el oeste salvaje de entonces, cerca de Carmi, Illinois" (Von Hagen 1947:32). A decir del biógrafo del viajero norteamericano, Von Hagen (1947:32), esta carta "despertó los latentes instintos andarines de John Stephens". Y esta "impresión" me parece doblemente importante: no sólo porque despertó la curiosidad viajera de Stephens, sino porque también es ilustrativa de la concepción que los norteamericanos de la primera mitad del siglo XIX tenían sobre los indios: eran básicamente los indios de las llanuras del Oeste, primitivos, bárbaros, involucrados en constantes guerras. Se ignoraba por completo la existencia de magníficos edificios en otras partes de América, ni mencionar que algunos "indios" pudieran haberlos construido.

Después de su viaje por el Oeste norteamericano, Stephens emprendió un nuevo viaje hacia Europa, que prolongó hacia el Oriente. Además de las obligadas ciudades europeas en Francia, Italia e Inglaterra, visitó Grecia, entonces convulsionada por la guerra contra Turquía, exploró el Nilo, y fue el primer norteamericano en visitar Petra, antigua ciudad ante la cual quedó fascinado. De vuelta en Inglaterra, conoció al arquitecto inglés Frederick Catherwood, con quien compartía su pasión por las antigüedades. Entonces comentaron una incipiente idea: la tesis de que las ruinas de Palenque eran de origen egipcio, cartaginés o fenicio - civilizaciones por cierto conocidas por Stephens y Catherwood-, no era del todo convincente, ya que no había gran similitud entre sus vestigios arquitectónicos. Muchos anticuarios de gabinete creían en las semejanzas entre las muy poco conocidas ruinas de Copán y Palenque y los edificios griegos, romanos, egipcios, 
chinos, etc., pero Stephens y Catherwood sospechaban lo contrario. Esbozaban la tesis de la continuidad. Había que realizar entonces un viaje a América para conocer las hasta entonces "misteriosas" ciudades "perdidas" y arruinadas. Emprendieron el viaje en 1839 y, al mismo tiempo que "descubrieron" y conocieron dichas ruinas, con sus palabras e imágenes las construyeron como misteriosas ciudades perdidas (Castañeda 1996:131 y ss.).

Con todo, resulta llamativo que el propio Stephens declarara que llegó a América en 1839 sin ninguna teoría sobre el origen de los constructores de las pirámides y si éstos eran o no ancestros de los actuales indios. Simplemente, Copán, Palenque y Uxmal le provocaban una fascinante curiosidad. Fue sólo cuando visitó Uxmal que formuló su versión de la tesis de la continuidad, que cito in extenso:

no había suficiente motivo para creer en la antigüedad que se atribuía a aquellas ruinas; que no necesitábamos acudir a ninguna nación del Antiguo Mundo para hallar a los que edificaron estas ciudades; que no eran ellas obras de un pueblo que hubiese desaparecido y cuya historia no existiese, sino que por el contrario había poderosas razones para creer que habian sido edificadas por las mismas razas que habitaban el país al tiempo de la conquista española, o por algunos progenitores suyos no muy remotos (Stephens 1969 [1841]:455. Cursivas de R.L1.).

A su regreso a Nueva York en 1840, Stephens conoció a otro apasionado viajero, el austriaco Emanuel von Friedrichsthal, a quien le recomendó visitar las ruinas de Yucatán procurándose llevar una cámara para hacer daguerrotipos (Taracena y Sellen 2006: 53-54). Un año después, en abril de 1841, tras haber visitado las ruinas de Uxmal y Chichén Itzá, Friedrichsthal entabló correspondencia con Justo Sierra O’Reilly, publicando un artículo titulado "Sobre los que construyeron los edificios de Yucatán, y su antigüedad" en el Museo Yucateco, periódico que dirigía Sierra O’Reilly. En este artículo, Friedrichsthal argumentó la tesis de la discontinuidad, es decir, que los indios contemporáneos no eran descendientes de los constructores de pirámides:

Pues aquí —escribió Friedrichsthal (1994 [1841]:443) — es precisamente en donde topamos con pruebas indubitables, de que entre sus habitadores primitivos se presentó una casta de hombres superiores, de la raza caucásica en apariencia.- Estas pruebas se hallaron entre las esculturas del Palenque, que son bastante consideradas y demostradas por el mundo sabio de Europa; y ahora últimamente, entre las soberbias ruinas, hasta hoy desconocidas, de 
Chichén Itzá y Uxmal.

Nada se ha hecho hasta ahora — continuó Friedrichsthal (1994:444, cursivas en el original) - para resucitar el espíritu de la nación que desapareció, y de cuya existencia únicamente han quedado esos hermosos monumentos, mudos epitafios colocados sobre el sepulcro de un pueblo que fue. Estos testigos son, sin embargo, bastante válidos y hábiles para probar que Yucatán estuvo una vez en manos de hombres muy adelantados en todo respecto.

Friedrichsthal establecía entonces una discontinuidad: los constructores de pirámides eran una "casta de hombres superiores", que construyeron "soberbias ruinas", "hermosos monumentos", un pueblo que fue, y que, nos diría páginas adelante el viajero austriaco, se caracterizó también por sus adelantados conocimientos en arquitectura, agricultura y escultura. En suma, "un pueblo avanzado en la civilización y el cultivo de las artes" (Friedrichsthal 2006 [1841]:73). Todo lo que los indios contemporáneos, evidentemente, no eran.

Justo Sierra O’Reilly abrazó con gusto la tesis de la discontinuidad. ¿Por qué? Sin ánimos de entrar en detalles de su biografía, este notable yucateco nació en Tixcacaltuyub, Yucatán, en 1814, recibió formación teológica y en derecho, y en el año de 1840 comenzó a figurar en la política yucateca decimonónica. Era momento de un acentuado conflicto entre tendencias centralistas y federalistas (Quezada 2001:121 y ss.), y en el que la elite intelectual yucateca, en la que destacaba Sierra, buscaba construir una identidad regional propia, acudiendo para ello a la historia de la región (España 2013; Taracena 2010). En este proceso de construcción nacionalista, de independencia de España y México así como de ascenso de liberalismo, los edificios en ruinas de la región se convirtieron en "ciudades perdidas" que podían ser "descubiertas" y "exploradas" (Castañeda 1996:108). En Yucatán, serían sobre todo los viajeros europeos y norteamericanos quienes llevarían a cabo estas tareas de "descubrimiento" y "exploración”, y sus relatos servirían para la construcción de la identidad regional yucateca (ver Florescano 2005; Morales 1987). Pero los relatos no eran todos coincidentes entre sí, y los yucatecos no los recibieron sin darles otras interpretaciones.

Tan pronto como salió a la luz el primer libro de Stephens sobre América, 
Incidentes de viaje en América Central, Chiapas y Yucatán, Sierra tradujo y publicó en el Museo Yucateco los capítulos referentes a Yucatán, es decir, del 23 al 25. Pero, como observan Arturo Taracena y Adam Sellen (2006:59), resulta llamativo que Sierra no publicara el capítulo 26, en donde Stephens expuso su teoría sobre la continuidad entre los constructores de pirámides y los indios contemporáneos. De hecho, en 1841 Stephens y Catherwood se encontraban de nuevo en Yucatán para explorar más de cuarenta edificios en ruinas, en 1842 falleció Friedrichsthal, y en 1843 apareció el segundo libro de viajes de Stephens sobre América, Incidentes de viaje a Yucatán, que Sierra O'Reilly tradujo entre 1848 y 1850 con el título de Viaje a Yucatán, cuando ya había estallado el violento episodio conocido como "guerra de castas" en el estado. La labor de traducción de Sierra fue más que eso; la edición en castellano de Viaje a Yucatán puede leerse como una acalorada discusión entre Stephens y Sierra en torno a la continuidad o discontinuidad entre los constructores de pirámides y los indios contemporáneos. Me detengo en ella.

\section{De traducción y notas. Viaje a Yucatán: una discusión entre Stephens y Sierra}

Si en su libro de 1841, Incidentes de viaje a América Central, Stephens consideraba que no tenía pruebas contundentes para sostener su tesis sobre la continuidad entre los constructores de pirámides y los indios contemporáneos, en su libro de 1843, Viaje a Yucatán, declaró que ahora tenía pruebas suficientes, expuestas a lo largo de las páginas de sus dos volúmenes. Sierra O'Reilly, que al momento de traducir el libro escribía "Consideraciones sobre el origen, causas y tendencias de la sublevación de los indígenas, sus probables resultados y posible remedio", no desaprovechó para agregar como notas al pie críticas esgrimidas en contra de los argumentos de Stephens. En este apasionante diálogo podemos encontrar una enfática disociación entre las categorías de constructores de pirámides y los indios contemporáneos.

Así, en el capítulo IV, donde relata su estancia en Mérida y la situación política de Yucatán, Stephens ofrece como primera prueba de la continuidad el arco del convento de San Francisco:

el arco solitario hallado en este convento es una prueba muy fuerte, si no concluyente, de que todas las ruinas dispersas sobre Yucatán pertenecieron a los mismos indios que ocupaban el país al tiempo de la conquista española, o, para volver con mi antigua 
conclusión, fueron obra de la misma raza, o de sus progenitores no muy lejanos. (p. 54).

Ante esta observación, Justo Sierra comienza la descalificación de las ideas de Stephens relativas al tema anotando al pie de página: "Sin embargo de la manera plausible e ingeniosa con que explica el autor su teoría, no solamente no parece concluyente, sino que es preciso calificarla de errónea" (p. 54, n. 5).

Otra de las pruebas que Stephens considera contundente es la que ofrece en el capítulo VIII, donde describe las ruinas de Uxmal. Se trata del hallazgo de los "rastros de una mano roja" en los vestigios. Escribe Stephens:

Los lineamientos y contornos de la mano eran claros y distintos en la impresión. Había cierto sentimiento de vida en los pensamientos excitados por aquel fenómeno, que casi presentaba la imagen de los ya extinguidos habitantes vagando en aquellos edificios. Había una circunstancia muy notable en aquellas manos, a saber: que eran demasiado pequeñas. Las nuestras, cuando las extendíamos sobre la impresión, la ocultaban completamente; y esa circunstancia era tanto más interesante cuanto que, según observación propia y ajena, la pequeñez de manos y pies de los indios actuales es uno de los rasgos más característicos de su conformación física (p. 109).

Sierra, por supuesto, vuelve al ataque:

Y éste es uno de los datos que sirven de base al sistema de Mr. Stephens, atribuyendo a la raza actual la construcción de los edificios arruinados que hay en el país. Cuando las inducciones se forman sobre conjeturas, cada uno es dueño de darles el valor que cuadre más a sus ideas (pp. 109-110, n. 2).

En realidad, hasta el pasaje del capítulo arriba citado, Sierra no había argumentado de manera elaborada sus descalificaciones. No vaciló en anotar que la inducción de Stephens se basa en "conjeturas" y que su teoría no es "concluyente". Pero no ofrece ningún contraargumento. Estos aparecen con la siguiente afirmación de Stephens con respecto a un monumento esculturado encontrado en Uxmal, cuya colocación le parece un enigma. Anota Stephens:

En mi opinión, sólo puede explicarse de una manera. Acaso era uno de los principales ídolos a que daba culto el pueblo de Uxmal, y lo probable es que lo enterraron allí cuando 
los habitantes abandonaron la ciudad, para que no fuera profanado, o tal vez los españoles cuando arrojaron a los habitantes y despoblaron la ciudad, para destruir todos los sentimientos religiosos de los indios, siguiendo el ejemplo de Cortés en Cholula, destruirían y enterrarían los ídolos (p. 113).

Ahora Sierra contraargumenta recurriendo a la historia y sostiene que las ruinas no estaban habitadas por los indios al tiempo de la Conquista. Si los españoles encontraron algunos indios celebrando ritos, era porque éstos los tenían que festejar en lugares apartados para los españoles (p. 113, n. 8). De hecho, esta cuestión va a ser el punto de mayor discusión a lo largo del libro.

De vuelta en Uxmal Stephens ofrece otra prueba relativa a la conformación física de los antiguos y su similitud con los indios actuales:

Si esta opinión es correcta, como yo lo creo, si este esqueleto presenta el mismo tipo de conformación física que todas las tribus de nuestro continente, entonces no hay duda de que esos descarnados huesos nos prohíben, con una voz que sale de la tumba, retroceder en busca de una nación antigua perteneciente al Viejo Mundo para hallar a los que construyeron esas ciudades arruinadas, y que ellas no son la obra de un pueblo que ha pasado ya y cuya historia está perdida, sino de la misma raza que, miserable, envilecida y degradada, se agrupa todavía alrededor de esas vastas ruinas (p. 177).

En su nota al pie, Sierra admite que en parte coincide con Stephens: efectivamente, la raza india contemporánea es "miserable, envilecida y degradada", pero, desde luego, no coincide con la tesis de la continuidad:

Pero es preciso convencerse de que si el autor presenta esa conclusión como un apoyo o prueba de la teoría que está empeñado en sostener, nada prueba ciertamente ni a nada conduce. Entre los individuos de una misma raza ha habido conquistadores y conquistados, señores y esclavos, y pueblos enteros han desaparecido, formándose otros nuevos con uno u otro resto disperso de los antiguos. Eso es lo que creemos que haya sucedido en Yucatán (p. 177, n. 8).

Así, a lo largo de Viaje a Yucatán, encontramos una discusión entre Stephens y Sierra en torno al problema de la continuidad y discontinuidad entre los constructores de pirámides y los indios contemporáneos. Desde luego no era una “discusión” realmente sostenida entre 
Stephens y Sierra. Este último sí criticaba los planteamientos del primero, pero si bien el viajero norteamericano no discutía las ideas del intelectual yucateco, sí criticaba enfáticamente las tesis de otros viajeros que suscribían implícitamente la tesis de la discontinuidad ya que, por lo general, su mayor preocupación era la del origen. En este orden de ideas, hacia el final del libro, Stephens destaca tres argumentos de la tesis de la discontinuidad: 1) que no existen tradiciones, 2) que el actual es un pueblo degenerado, y 3) la inexistencia de documentación histórica. A ellos Stephens responde que el hecho de que no existan tradiciones entre los indios actuales y que estos sean una raza degradada se debe principalmente a la "despiadada política" de la conquista española que borró tradiciones y causó la degeneración de los indios contemporáneos. Por último, añade que es falso que no existan documentos históricos, ejemplos de los cuales él revisó en Ticul y Maní.

No obstante, a pesar de que Stephens suscribe la tesis de la continuidad, sí establece una diferenciación entre los constructores de pirámides, quienes conformaron "un poderoso, antiguo y misterioso pueblo” (p. 410) y la actual raza india, a la cual consideró una "antigua pero degradada raza" (p. 323). En esta diferenciación Sierra conviene con Stephens, aunque encontramos algunas diferencias.

Sobre lo anterior, Julio Alfonso Pérez Luna (2002:219) escribe que ante los ojos de Stephens, "el indígena, como persona, es depositario de todas aquellas características de tipo negativo que, en un momento dado, justifican una condición de sometimiento". Sobre todo, Stephens describe a unos indios "dóciles", que contrastan con los constructores de pirámides "fieros", de "sangrienta resistencia". Los indios contemporáneos son "tranquilos", veneran dócilmente a sus amos. De hecho, Stephens (2003:127) diría que estas dos razas "caminan juntas en armonía". Si bien los indios actuales ya no son esclavos, escribe Stephens (2003:128), han “quedado después como sirvientes”. Son “dóciles y apacibles, enemigos del trabajo" (2003: 128), caracterizados también por una "usual embriaguez" (2003:130). Aunque, a diferencia de los indios norteamericanos, cuando los indios de Yucatán se embriagan "se vuelven más dóciles y sumisos", y a pesar de usar machete, "jamás hacen uso de él para causar daño" (2003: 212). Con descripciones como las anteriores, Pérez Luna argumenta que a partir de esta visión sobre los indios, se justifica su sometimiento e incluso el que puedan servirles a Stephens como bestias de carga en sus exploraciones. 
En este último punto Sierra coincide con Stephens: la raza india actual es una raza degradada, pero cuestiona la idea de docilidad. Tal vez algunos indios eran dóciles cuando el viajero norteamericano visitó Yucatán, pero “iQué diferencia en ocho años!”, escribe enfáticamente Sierra (en Stephens 2003:128, n. 7). Los indios que son objeto de preocupación de Sierra no son dóciles, sino bárbaros. A diferencia del contraste que establece Stephens, entre los antiguos constructores "fieros" de "sangrienta resistencia" y los actuales indios dóciles, Sierra consideraba que los fieros eran los indios contemporáneos. La docilidad atribuida por Stephens a estos indios, escribió Sierra (en Stephens 2003:324, n. 1), "hace más honor a su buen corazón que a sus conocimientos etnográficos sobre Yucatán”. En efecto, en Los indios de Yucatán, Sierra no sólo argumentó a favor de la tesis de la discontinuidad, sino también que, desde el momento de la conquista, esta raza estaba conformada por "tribus belicosas" (Sierra 1994:28), las cuales guardaron un rencoroso odio a la raza conquistadora. "Su carácter era indómito y guerrero — escribe Sierra (1994:94)—. Hemos visto la prueba de eso, en la tenaz y fiera resistencia que opusieron hasta el fin a la invasión española”. Es este rencor histórico el que, según Sierra, va a explicar en buena medida el levantamiento indio de 1847 y el que va a justificar la asimilación de esta raza, cuando no su pleno exterminio apoyado por las tropas estadunidenses.

Ciertamente, la cuestión sobre quiénes eran los ancestros de los indios naturales de América precedió a la discusión entre Stephens y Sierra. Pero el saber producido por Stephens y sus contemporáneos gestó una diferenciación mucho más acentuada entre, por un lado, el pasado admirable y "misterioso" de los constructores de pirámides (del cual antes sólo se escuchaban algunos vagos rumores) y, por otro, la condición degenerada y miserable de los indios contemporáneos. Así, el célebre obispo e historiador de Yucatán Crescencio Carrillo y Ancona, consideró que los indios actuales y los antiguos constructores de pirámides constituían la "misma raza". Asumía también que los antiguos desarrollaron una grandiosa civilización, "la más avanzada entre la de otros pueblos del Nuevo Mundo" (Carrillo 1937 [1881]:34), pero de sus grandes logros sólo quedó la lengua, a la cual rescata como un elemento identitario regional. En contraste, si bien los indios actuales le parecían "menos feos y más limpios que el resto de los indios mexicanos" (Iturriaga 2010:143), no dejaba de considerarlos bárbaros. Nos encontramos entonces con 
dos categorías distintas que incluso son representadas en espacialidades diferentes. Por ejemplo, en los relatos de viaje de la inglesa Alice Dixon Le Plongeon, esposa del controvertido Augustus Le Plongeon, ambos amigos de Carrillo y Ancona, encontramos, de acuerdo al análisis literario realizado por Romina España (2015), un "espacio utópico" que es el del pasado: una "Edad de Oro" habitada por sabios mayas expertos en el conocimiento astronómico y teológico, donde reina el colectivismo y la ley natural y en cuyo paisaje encontramos la celebración de ceremonias y una notable grandeza arquitectónica. Este espacio contrasta con la "Arcadia" de los indios "contemporáneos" a Dixon. Enfatizo “contemporáneos" porque en realidad son indios alocrónicos (Fabian 1983), a los cuales la viajera inglesa les niega la coevalencia: son indios primitivos y exóticos, "buenos salvajes" que se rigen por principios de igualitarismo, minimalismo y naturalismo. Son unos descendientes en decadencia de los sabios constructores de pirámides que, por lo tanto, habitan un espacio diferente al utópico de la gran civilización maya.

\section{Los mayas actuales no tienen cultura maya}

Hay que tener cuidado pues en el uso del término maya cuando se investiga la cultura de los grupos mayances actuales, que aun cuando lingüistica y somáticamente son mayas, culturalmente son otra cosa.

Alfredo Barrera Vásquez

Ya bien entrado el siglo XX, viajeros provenientes de diversos lugares continuaron arribando a Yucatán y siguieron discutiendo el tema de si los indios contemporáneos eran o no los descendientes de los constructores de pirámides, si eran o no mayas. Por ejemplo, la viajera norteamericana Maude Mason Austin (2005:90) escribió sobre su visita a Yucatán: "es difícil creer que los indolentes y apáticos indios mayas que viven en la selva de Yucatán, sean descendientes directos de estos arquitectos mayas que concibieron y construyeron Chichén Itzá". Pero exploradores como Stephens dejaron de ser las principales autoridades respecto a los mayas y su lugar fue ocupado por las recientemente fundadas ciencias antropológicas, especialmente por dos de ellas: la arqueología y la antropología sociocultural. Entonces comenzó propiamente a hablarse de la "cultura maya" (ya no sólo de los antiguos y misteriosos constructores de edificios). Incluso ésta comenzó 
a ser definida científicamente. Así, el más destacado arqueólogo mayista de inicios de siglo XX, el norteamericano Sylvanus Morley, definió a la cultura maya de la siguiente manera: "la cultura maya, técnicamente es la que corresponde especialmente a la típica arquitectura [se refiere a la bóveda] y la singular escritura jeroglífica".

En 1941, cien años después de la publicación del primer libro de viajes de Stephens sobre América, el antropólogo norteamericano Robert Redfield publicó otro influyente libro sobre la región, hoy un clásico en la antropología social, The Folk Culture of Yucatan, traducido al castellano como Yucatán, una cultura de transición. El libro constituye la síntesis de un gran proyecto de investigación auspiciado por la Carnegie Institution of Washington, de cerca de diez años de duración, con un equipo de cinco investigadores y que cubrió diversas localidades de la península de Yucatán. Dicho proyecto, cabe destacar, marca a juicio de una antropóloga estudiosa de la historia de la disciplina en el estado "el origen de la investigación propiamente antropológica sobre los mayas contemporáneos" (Guzmán 2005:94).

El Yucatán de Redfield no sólo se volvió famoso por su teoría del continuum folkurbano. De acuerdo con Quetzil Castañeda, la etnografía de Redfield y su colaborador Alfonso Villa Rojas sobre la comunidad maya de Chan Kom se convirtió en canónica, una suerte de "ejemplar paradigmático" (Kuhn 2005), no sólo de los estudios de comunidad, sino de los mayas mismos: "la representación etnográfica de Chan Kom permanece en Yucatán como la cultura maya yucateca por excelencia" (Castañeda 1996:45, cursivas en el original). Así, según Castañeda (1996:56), el estudio sociológico de Redfield fue un momento significativo en la invención de la cultura maya. Pero hay que advertir que lo que hoy denominamos cultura maya era para Redfield ante todo una cultura folk — no maya, ni hispana-, que se encontraba progresando. La imagen de los mayas folk modernos, argumenta Castañeda, se añade a la de los mayas misteriosos. Al respecto, me parece que en el enfoque de Redfield no sólo están imperando las perspectivas modernistas sobre el cambio social (desde Maine a Durkheim, pasando por Tönnies), sino también los postulados sobre la aculturación de la antropología cultural norteamericana. Recordemos que Redfield mismo fue uno de los autores del célebre memorandum sobre el estudio de la aculturación (Redfield, Linton y Herskovits 1936). Bajo esta perspectiva, el contacto entre culturas produce fenómenos nuevos, y tal ha sido el caso de Yucatán. Según Redfield, en la 
península no encontramos una cultura maya pura, tampoco una cultura española libre de otras influencias culturales, sino el producto de la aculturación de éstas: la cultura folk de Yucatán. Como observa Castañeda, Chan Kom es justo el elemento representativo de esta cultura folk, a diferencia de la más urbanizada ciudad de Mérida o la marcadamente tribal aldea de Tusik.

Pero como había asentado anteriormente, no me interesa únicamente la invención de la cultura maya. Sobre todo, me importa el planteamiento de la tesis de la discontinuidad en la obra de Redfield. Considero que no se puede decir que el antropólogo norteamericano la plantee de manera explícita y contundente, pero sí la sugiere. Asimismo, me parece que el trabajo socio-antropológico de Redfield y su equipo tiene varias implicaciones importantes para el tema aquí tratado. Destaco dos.

Primero, en sus reportes de investigación iniciales para la Carnegie, Redfield era enfático en que estaba tratando con una cultura contemporánea, con una cultura "viva". Él era un verdadero pionero en la etnología y antropología social de la región, a la cual quería legitimar. En este sentido, no bastaba el conocimiento arqueológico sobre el pasado, ya que, de acuerdo con Redfield, "la cultura de los habitantes actuales de Yucatán no es maya, en el sentido de que no representa los modos de vida de los habitantes pre-colombinos de la península” (Redfield 1933:290). En este sentido, “el arqueólogo, no el etnólogo, trata con esa cultura antigua y extinta. Entonces, no hay una etnología mayista [como si hay una arqueología mayista, R.Ll.]. La etnología trata con la cultura de los pueblos vivientes, y en Yucatán esta cultura viva no es maya ni española" (Redfield 1933:290). Estamos entonces frente a una disociación entre arqueología mayista y etnología de la cultura folk viva, así como entre mayas antiguos (lo que en este discurso es una suerte de tautología) e indígenas contemporáneos. Una discontinuidad que no es de carácter ontológico (los mayas antiguos y los folk contemporáneos son dos entidades completamente distintas), pero sí históricacultural con importantes implicaciones disciplinarias.

Segundo, como se ha mencionado arriba, encontramos en Yucatán una cultura folk compartida. Pero los indígenas de Chan Kom no eran iguales a los de Tusik en el oriente de la península. La diferencia para Redfield radicaba entonces en el temperamento, no en la cultura. El temperamento de Chan Kom estaba orientado hacia el progreso y la modernidad. Tusik, en cambio, miraba hacia al pasado y a la tradición. Resulta un tanto "iluminador" 
cómo Chan Kom, el topos por excelencia de la cultura maya contemporánea (de acuerdo con Castañeda), concebía, según Redfield, a Chichén Itzá (el topos por excelencia de la cultura maya antigua): no como el pasado glorioso y misterioso de los mayas, sino justo como el progreso y el futuro. El camino que llevaba de Chan Kom a Chichén Itzá era conocido por los habitantes de la primera comunidad como "el camino hacia la luz" (the road to the light). La "luz" era la presencia de los norteamericanos en la zona arqueológica, principalmente investigadores de la Carnegie de Washington. Chichén Itzá no era el símbolo de la continuidad entre mayas antiguos y modernos, "no era un símbolo de un pasado olvidado, sino una guía hacia el futuro" (Redield y Villa Rojas 1934:30). Años más tarde, en su reestudio de Chan Kom, Redfield (1950) constataría que de hecho esta comunidad "eligió el progreso". Los indígenas contemporáneos de Yucatán no poseían una cultura maya continuadora de la antigua civilización maya, sino una aculturada cultura folk en vías de progreso.

Si bien la obra de Redfield no plantea entonces la tesis de la discontinuidad de manera explícita, sí ha tenido impacto en posteriores formulaciones de esta tesis. De acuerdo con la antropóloga Violeta Guzmán, el trabajo del antropólogo norteamericano "construyó una imagen de la sociedad maya ideológicamente desfasada entre lo real y lo imaginario" (Guzmán 2005:98). Y más adelante escribe que los trabajos antropológicos que siguieron el modelo de Redfield produjeron "dos mundos diferenciados y hasta cierto punto antagónicos: el tradicional atrasado y por lo tanto lleno de costumbres y creencias ancestrales; y el moderno progresista donde el indígena es situado en tránsito étnico hacia la modernidad" (Guzmán 2005:98, cursivas en el original). Así, Guzmán argumenta que es esta visión dicotómica la que ha producido una visión discontinuista entre mayas antiguos y contemporáneos:

Como resultado de esta visión dicotómica que se generó sobre los mayas modernos entre tradición/modernidad, los estudios sobre los mayas yucatecos del siglo XX nos muestran una imagen fragmentada del mundo de vida de este pueblo indio y sugiere una falta de continuidad histórica y cultural donde según estos trabajos, los actuales mayas yucatecos poco o casi nada tienen que ver con sus antepasados prehispánicos y coloniales. Así, parece existir una ruptura entre el pasado y el presente, donde el mundo de vida de estos mayas queda subsumido bajo la categoría de campesinos, despojando de este modo a los mayas yucatecos y a otros grupos indigenas de su derecho a la diferencia (Guzmán 
2005:109. Cursivas de R.Ll.).

Encontramos de nuevo la tesis de la discontinuidad. Su consecuencia política, para Guzmán, es clara: se niega el derecho a la diferencia de los mayas yucatecos. Al final del capítulo volveré sobre este punto.

Un episodio que resulta por lo demás ilustrativo de la discusión de la época y en donde encontramos formulaciones explícitas tanto de la tesis de la continuidad como de la de la discontinuidad es el que sostuvieron, si bien de manera poco desarrollada, el fundador de las ciencias antropológicas en Yucatán, Alfredo Barrera Vásquez, y el intelectual y escritor también yucateco José Díaz Bolio. El primero sostuvo la tesis de la discontinuidad, el segundo la de la continuidad.

Barrera Vásquez llevó a cabo su formación antropológica en el Museo Nacional de México y en las universidades de Tulane, Chicago y Columbia, en donde estudió los Libros de Chilam Balam, un conjunto heterogéneo de textos religiosos, históricos, médicos, cronológicos, astronómicos, proféticos, rituales y literarios. Ya desde el siglo XIX, diversos estudiosos esperaban encontrar una suerte de "piedra de rosetta" maya en los jeroglíficos de los edificios arqueológicos. Muchos quedaron decepcionados, ya que las inscripciones en las ruinas arqueológicas no relatan la historia política de los mayas, sino contienen sobre todo referencias a la religión y al futuro. En cambio, los libros de Chilam Balam sí cuentan la historia política de los mayas (o algunas versiones de ella), y Barrera Vásquez se dedicó a traducirla, editarla y estudiarla. Aquí sólo me interesa destacar un aspecto de esta historia: la tesis de la discontinuidad presente en la interpretación del filólogo y antropólogo mayista.

A partir del estudio de los Chilam Balam, Barrera Vásquez argumentó que los mayas contemporáneos no son los descendientes de ninguno de los tres grupos políticos que construyeron la cultura maya entre los siglos V y XV, definida por Morley a partir de la arquitectura y los jeroglíficos: los Itzáes, los Xiu que arribaron a Uxmal y los Cocom de Mayapán. De acuerdo con Barrera Vásquez, los indígenas contemporáneos eran los descendientes de una población que ocupaba la península previamente a los tres grupos mencionados, es decir, antes del siglo $\mathrm{V}$, por lo que se trata de una población "pre-maya" (Barrera Vásquez 1949:121-122). Aquí, la tesis de la discontinuidad implica dos entidades 
distintas: una cultura es la de los mayas constructores de las pirámides, otra la de los mayas milperos.

Barrera Vásquez considera que, en términos lingüísticos y somáticos, los indígenas actuales de Yucatán son mayas, pero no poseen cultura maya. Son de "cultura milpera", heredada de los pre-mayas del siglo V. Como figura pública que era, Barrera Vásquez publicó en la prensa un artículo con estas ideas con un título provocador: "La cultura maya es patrimonio de los pueblos mayas, pero no todo pueblo maya ha tenido cultura maya" (1942). En este texto escribió que "la cultura maya cesó, pero el pueblo maya milpero continuó con su propia cultura y así continúa hasta hoy. La cultura maya es un incidente en la historia del pueblo maya de Yucatán” (Barrera Vásquez 1986:30). Aseveraciones polémicas. Y las respuestas no esperaron mucho tiempo. Una de ellas corrió a cargo del intelectual y escritor José Díaz Bolio, defensor de la tesis de la continuidad.

Díaz Bolio comienza su crítica declarando que "Da motivo a este breve estudio sobre la relación entre mayas antiguos y modernos, la opinión, bastante generalizada en el propio Yucatán, de que los actuales mayas no son los descendientes de aquellos que levantaron la cultura del Mayab” (Díaz Bolio 1942:5). Por una parte, esta nota nos sugiere que la opinión generalizada en Yucatán era que no había continuidad entre mayas antiguos y modernos, pero por otro lado nos interesa que Díaz Bolio atribuía a los escritos de Barrera Vásquez (a los que intenta refutar) parte de la responsabilidad de esta situación.

De acuerdo con Díaz Bolio, el argumento de Barrera Vásquez era que la milpa de los mayas actuales constituye precisamente la razón por la que éstos no son descendientes de los mayas antiguos. Ante una división del trabajo entre un sector agricultor, milpero, y una élite teocrática, había una gran diferencia cultural. La última clase pereció, y la primera, al seguir practicando la milpa, nunca pudo desarrollar la alta cultura maya. Había una oposición entre milpa y arte. Resulta interesante que Barrera Vásquez argumentara que, justo por la milpa, los mayas no pudieran desarrollar una elaborada vida espiritual ya que, como veremos más adelante, bajo concepciones contemporáneas, la milpa va a ser uno de los topos privilegiados de la reproducción de la vida espiritual, del núcleo duro, de la matriz cultural de los mayas desde tiempos prehispánicos; es decir, un locus predilecto de la tesis de la continuidad. En oposición a Barrera Vásquez, Díaz Bolio (1942:7) argumentó que el maíz "produce, sucesivamente: vida agrícola, sedentaria, culta, artística y por ende, 
espiritual".

A diferencia de la discusión entre Stephens y Sierra, Barrera y Díaz Bolio sí discutieron en persona. Ante las críticas del segundo, el filólogo respondía en una plática: "Estos mayas de las casas de paja (no) son los mismos que levantaron estos monumentos. Estos, siempre han vivido así" (Barrera en Díaz Bolio 1942:13). Junto a la oposición de milpa y arte encontramos otra: casas de paja y monumentos (arqueológicos). Para Díaz Bolio, los actuales mayas sí son los descendientes de los antiguos Xiu, para lo cual se basa, entre otras pruebas, precisamente en las profecías contenidas en los Chilam Balam estudiados por Barrera Vásquez. Sin embargo, al igual que Stephens, Díaz Bolio consideraba que los mayas actuales, descendientes de los antiguos sacerdotes mayas, decayeron a lo largo de la historia: "el sacerdocio como minoría se extinguió de hambre; o bien, los que quedaron decayeron y 'la casta sacerdotal se mezcló con la plebeya y al acontecer la conquista ya sólo quedaban unos cuantos exponentes de su existencia"' (Díaz Bolio 1942:18). Nuevamente, la tesis de la continuidad no excluye decadencias ni degeneraciones. Y la prueba definitiva de la continuidad es, para Díaz Bolio, que fray Diego de Landa "afirma que el pueblo conocido por él fue el mismo que levantó los monumentos mayas"; y "Landa es la autoridad, e interpretándolo, encontramos la más fuerte base para refutar a los que niegan - motu proprio- que los actuales mayas de Yucatán no descienden de aquellos que en la antigüedad levantaron la cultura del mismo nombre" (Díaz Bolio 1942:20).

En estas discusiones encontramos varios elementos que me interesa destacar: primero, que la tesis de la discontinuidad no necesariamente implica juicios de valor negativos; segundo, que la discusión sobre la descendencia se inserta en nuevas tramas conceptuales, en este caso, de las ciencias antropológicas; tercero, que a la categoría de mayas se le ha agregado nuevas imágenes: además de la de los misteriosos antiguos constructores de pirámides, la de tradicionales y modernos campesinos folk y milperos; cuarto, que ante estas imágenes sobre los indígenas contemporáneos como sujetos en vías de progreso y modernidad, se destinan políticas y programas de progreso, como el proyecto de la Carnegie, o bien, las políticas indigenistas y proyectos de antropología aplicada de Barrera Vásquez, que buscaban incorporar a los indígenas al progreso. 


\section{La tesis de la continuidad como recurso de reivindicación étnica}

Como ha observado la antropóloga yucateca Ella Fanny Quintal, hasta la década de los ochenta del siglo XX, la antropología sobre Yucatán estuvo marcada por "un enfoque que combina economía, sociología e historia y relativamente poca antropología" (Quintal 2002:228). Sin embargo, ya desde la década de los setenta —advierte Quintal (2002: 228) - , los antropólogos Alicia Barabas y Miguel Alberto Bartolomé se interesaron "en la población indígena de la Península qua mayas y no como lo hacía la línea de investigación imperante, en tanto campesinos". En efecto, fueron Barabas y Bartolomé quienes no solamente se interesaron en los mayas (ya no en indios o en campesinos folk), sino quienes también se preocuparon por "el derecho de los descendientes de las sociedades originales de América a la diferencia y a luchar y a resistir en contra de las imposiciones del colonialismo interno" (Quintal 2002:228). Es decir, plantearon también la tesis de la continuidad entre los mayas antiguos y los contemporáneos. Una obra que ilustra esta concepción es La dinámica social de los mayas de Yucatán de Miguel Bartolomé, publicada en 1988, en donde argumenta que los jmeno'ob (los chamanes mayas) son el principal elemento de continuidad y resistencia cultural e ideológica entre los mayas de Yucatán y los principales defensores de su conciencia social. De acuerdo con este antropólogo argentino, en Yucatán encontramos "una cultura cuya vida contemporánea se basa [...] en una tradición de milenios que hacía imposible olvidar su alta profundidad histórica" (Bartolomé 1988:15).

Al inicio de La dinámica social, Bartolomé revisa distintos trabajos antropológicos y sociológicos sobre Yucatán y reconoce y destaca el problema de la continuidad y discontinuidad entre los mayas antiguos y contemporáneos. Al respecto, escribe: “con pocas excepciones las monografías [sobre los mayas de Yucatán] brindan un panorama del cual se desprendería que los únicos mayas son los del pasado y no los del presente: ahora sólo hay "campesinos"” (Bartolomé 1988:29. N. 16). Al igual que Díaz Bolio y otros antes que él, Bartolomé percibe que no se trata únicamente de un problema de las ciencias sociales, sino también de una cuestión política e ideológica más amplia:

en el ámbito social peninsular contemporáneo —escribe Bartolomé (1988:30-31)—, los grupos económica y socialmente privilegiados consideran a los nativos como una 'raza degenerada', cuya relación con los grandes arquitectos mayas se ha perdido totalmente. 
Esta ideología clasista, etnocéntrica y discriminatoria es la que ha llegado hasta el presente, buscando estigmatizar al colonizado, para lograr que éste vea en su propia identidad la causa de su papel social subordinado.

Y para esta situación ofrece una explicación: los colonizadores y dominantes han intentado deshistorizar a los mayas colonizados, negándoles su historia, y esto ha impactado en la manera en que los mismos mayas se ven a sí mismos. La tesis de la discontinuidad, la disociación entre los antiguos constructores de pirámides y los indios contemporáneos, o entre mayas pretéritos y presentes, es para Bartolomé un producto del colonialismo externo e interno. Por ejemplo, refiere a Justo Sierra O'Reilly: "A mediados del siglo XIX la voluntad de deshistorizar al colonizado llegaba a tales niveles, que uno de los más ilustres ensayistas yucatecos, Justo Sierra O’Reilly, negaba que la población maya fuera descendiente de los constructores de Uxmal, Chichén Itzá, Kabah, y de los cientos de monumentos que atestiguan el pasado de la cultura" (Bartolomé 1988:30).

¿Qué pruebas de la tesis de la continuidad entre antiguos y contemporáneos ofrece Bartolomé? En realidad son diversas: "la vigencia del idioma, de ciertas pautas culturales, de algunos rasgos materiales $\mathrm{y}$, fundamentalmente, de una conciencia social específica" (Bartolomé 1988:19). Pero todos estos elementos se alimentan de un factor fundamental, del "mantenimiento de una conciencia social" (Bartolomé 1988:20), de una "matriz cultural" que se expresa particularmente en la "institución chamánico-sacerdotal maya", es decir, los jmeno'ob. Este elemento del "sistema religioso prehispánico" es el que "expresa mejor la continuidad reestructurada y reelaborada de la cultura" (Bartolomé 1988:32-33). Así, los jmeno'ob, los rituales que conducen, como el jetzmek, devienen en "actos de resistencia" (Díaz Cruz 2002a), en elementos constitutivos de una "cultura de la resistencia" que fortalecen la idea, marcadamente comunitarista, de una unidad cultural y social, de un "Pueblo": el "Pueblo Maya".

En este orden de ideas, para Bartolomé "los colonizados fueron forzados a dejar de ser mayas para pasar a ser 'indios', a quienes su herencia cultural les estaba negada y para quienes la vida política y económica se articulaba, principalmente, en función de su condición de colonizados" (Bartolomé 1988:23. Cursivas de R.L1.). Sin embargo, tengamos cuidado con las palabras. A partir de lo presentado en este capítulo, resulta problemático 
decir que los colonizados dejaron de ser mayas, pues en términos estrictos no lo eran anteriormente. La antropología de Bartolomé (pero también diversos movimientos indianistas) naturaliza la categoría de maya, la vuelve ahistórica y poco problemática, mayaniza a los indígenas de la península para posteriormente denunciar una desmayanización.

La obra de Bartolomé, sus postulados sobre la continuidad entre mayas antiguos y contemporáneos, ha tenido un impacto considerable en la producción antropológica de las últimas dos décadas así como, de manera directa o indirecta, en los movimientos de reivindicación del Pueblo Maya. Un elemento importante a destacar es que a diferencia de etapas anteriores, la tesis de la continuidad es formulada ahora sin elementos de degeneración o de decadencia: se trata ante todo de la continuidad de una tradición de valor positivo. La tesis de la continuidad se impregna ahora de juicios de valor positivos. Los actuales ya no son indios degenerados o campesinos folk que sólo ven hacia la modernidad y el progreso, sino también se interesan en mantener el valor de su tradición. En ocasiones, incluso, no se oponen ya tradición y modernidad. Por ejemplo, la antropóloga Violeta Guzmán escribe en un libro sobre identidad maya: "nosotros planteamos que no existe una ruptura entre tradición y modernidad sino una continuidad donde los elementos que integran la tradición son actualizados para enfrentar el cambio social y la modernidad" (Guzmán 2005:101. Cursivas de R.L1.).

Con respecto a la antropología contemporánea en Yucatán, Guzmán sostiene que una de las dos tendencias dominantes de "la nueva antropología yucateca" es aquella que "ha privilegiado el análisis de la cultura maya actual (Terán y Rasmussen, Michel Antochuw, Pérez Taylor), presentándolos [sic, se refiere a los mayas actuales, R.Ll.] como los herederos de los mayas prehispánicos que han logrado, en este largo proceso histórico, refuncionalizar muchos de los elementos culturales propios que al combinarlos con los provenientes de la sociedad dominante, les ha permitido seguir existiendo como parte de la cultura maya" (Guzmán 2005:109-110. Cursivas de R.L1.). Ahora, los locus privilegiados de la continuidad van a ser, a diferencia de lo postulado por Barrera Vásquez, la milpa y los rituales alrededor de ella, así como los jmeno'ob dirigentes de rituales.

Entre los movimientos indios también encontramos la formulación y defensa de la tesis de la continuidad. Por ejemplo, uno de los intelectuales mayas más activos, el 
etnolingüista Bartolomé Alonzo (1993), sostiene la hipótesis de que

el pueblo maya tiene una historia propia, interferida y negada a partir de la dominación colonial, pero nunca cancelada. Su cultura, como producto de dicha historia, se ha mantenido viva a pesar de la dominación, y sigue siendo el fundamento de la vida individual y colectiva de sus miembros, sin negar que ha recibido serias influencias de la cultura occidental (Alonzo 1993:37).

Al igual que Miguel Bartolomé, Alonzo atribuye al colonialismo interno la persistencia de la tesis de la discontinuidad, ya que la historia nacional oficial ha desconsiderado la historia de las poblaciones indígenas del país. De ahí que resulte

preciso decir que la historia nacional se interpreta y enseña de manera fragmentaria y tendenciosa, pues en ella se soslaya una solución de continuidad entre el pasado prehispánico y la presencia de los pueblos indígenas, impidiendo una visión global y coherente de la misma, pues se tiene la impresión de que la historia de México se inicia con la llegada de los españoles, con la que supuestamente se cancela el pasado indígena, que se distorsiona y manipula, recurriendo a él sólo cuando es útil para justificar la historia de la dominación (Alonzo 1993:39).

Por lo tanto, propone Alonzo, una tarea clave del movimiento de resistencia maya es la recuperación de la historia del Pueblo Maya reinterpretada a partir de la tesis de la continuidad. Por lo tanto, en el texto aquí revisado, el etnolingüista escribe que "se pondrá énfasis en la historia particular del pueblo maya peninsular, abarcando desde el pasado prehispánico hasta la actualidad, con la finalidad de mostrar su continuidad y tener una visión amplia y coherente de sus luchas de resistencia ante el proceso de dominación colonial" (Alonzo 1993:43). Aquí, la tesis de la continuidad sirve para plantear un "proyecto histórico del pueblo maya". Si la tesis de la discontinuidad de carácter colonialista negaba el derecho a la diferencia, la tesis de la continuidad va a ser un recurso precioso para afirmar dicho derecho.

Así, la tesis de la continuidad comienza a funcionar como un instrumento de lucha política, como un recurso a controlar para las reivindicaciones étnicas. Y, desde luego, no son sólo los movimientos indios los que plantean la tesis de la continuidad. Además de los antropólogos y otros científicos sociales simpatizantes de estos movimientos, la legislación 
internacional en torno a los derechos de los pueblos indígenas y tribales, como el célebre Convenio 169 de la Organización Internacional del Trabajo, también descansan en la tesis de la continuidad. Si bien dicho convenio no define necesariamente a los pueblos indígenas, los criterios para describir a los pueblos que pretende proteger sí implican la tesis de la continuidad. Por ejemplo, uno de sus criterios es que son pueblos indígenas "por el hecho de descender de poblaciones que habitaban en el país o en una región geográfica a la que pertenece el país en la época de la conquista o la colonización o del establecimiento de las actuales fronteras estatales y que, cualquiera que sea su situación jurídica, conservan todas sus propias instituciones sociales, económicas, culturales y políticas, o parte de ellas" (C169. Cursivas de R.L1.).

Podemos apreciar ahora por lo menos tres transformaciones importantes en la tesis de la continuidad: la primera es que se enmarca en nuevas tramas conceptuales de las ciencias sociales inspiradas por los movimientos anticoloniales así como en enfoques simbólicos sobre la cultura y los rituales; en segundo término, se articula con proyectos políticos y demandas de los pueblos indígenas así como con posiciones filosóficas “comunitaristas" (ver Mulhall y Swift 1996), de reconocimiento (ver Taylor 2009) y de derecho a la diferencia (ver Wade 2000; Young 1989); por último, la tesis de la continuidad adquiere una positividad y se considera a la tesis de la discontinuidad como un producto del colonialismo, por lo que se le atribuyen valores negativos.

Sin embargo, en años recientes, la tesis de la continuidad también ha sido desafiada por diversos actores, entre ellos etnohistoriadores, antropólogos y otros interesados en la cultura maya. Por el momento, no me detendré en los usos contemporáneos de la tesis de la continuidad ni tampoco en sus detractores, pues sobre esto versará el siguiente capítulo.

\section{Continuidades, discontinudiades; asociaciones, disociaciones; peligros de las tesis}

A partir de las discusiones anteriores hemos visto cómo se han formulado las tesis de la continuidad y de la discontinuidad de distintas maneras y con diferentes implicaciones en diversos campos y arenas. Como mencioné al inicio de este capítulo, en sí mismas, las tesis de la continuidad y de la discontinuidad no conllevan juicios de valor, no son necesariamente de carácter normativo. Sin embargo, históricamente, han estado saturadas de juicios de valor, han estado enmarcadas en distintas tramas conceptuales y relaciones de 
saber y poder. En el caso de Stephens, la tesis de la continuidad no conllevaba necesariamente juicios de valor positivos en torno a la población india contemporánea, pues la consideraba una versión decaída de la antigua, como indios dóciles que bien servían a las tareas del explorador norteamericano. Por su parte, la tesis de la discontinuidad defendida por Sierra O'Reilly estaba cargada de fuertes juicios de valor negativos sobre la población india contemporánea; incluso, la tesis de la discontinuidad se articulaba con intereses de exterminio de la población india. En cambio, mientras que para Redfield y Barrera Vásquez la tesis de la discontinuidad no implicaba juicios de valor negativos en torno a la población indígena contemporánea, para Díaz Bolio la tesis de la continuidad sí considera a la población maya moderna como una versión decaída de la antigua, si bien conserva atributos positivos como el arte de la limpieza. Es hasta fechas más recientes que la tesis de la continuidad ha sido formulada a partir de una valoración enfáticamente positiva y que se ha convertido en un recurso importante de reivindicación étnica, como en los trabajos de Bartolomé y Alonzo.

Podemos apreciar entonces diversos cambios en la discusión en torno al problema de la continuidad y discontinuidad entre mayas antiguos y contemporáneos. Los actores involucrados, así como las tramas conceptuales, han cambiado. De viajeros, exploradores y escritores e intelectuales, encontramos posteriormente antropólogos y otros científicos sociales, así como intelectuales indígenas y órganos internacionales. No se trata de una historia de sustituciones: viejos actores permanecen, nuevos se suman. No obstante, las autoridades en el saber en torno al problema sí han mutado. La ciencia y los instrumentos legales comienzan a tener un mayor peso y a fungir como recursos a controlar por diversos actores. Las pruebas para "comprobar" las tesis también han cambiando. Desde el recurso en el siglo XIX a las semejanzas físicas y arquitectónicas entre los constructores de pirámides y los indios actuales, los relatos de libros como los Chilam Balam, hasta la comparación de la etnografía contemporánea con la etnohistoria y la arqueología en los siglos XX y XXI. Todas estas pruebas de continuidad o discontinuidad están inmersas en distintos saberes en torno a la población denominada maya.

Ahora, cabe preguntarnos una cuestión fundamental para terminar este capítulo. ¿Podemos sostener que estas representaciones sobre mayas antiguos y contemporáneos son todas, a decir de Guzmán (2005:111), “identidad[es] estereotipada[s] proclive[s] a la 
sumisión y la pasividad ante la dominación"? Me parece que no. En las discusiones y enfrentamientos entre las tesis de la continuidad y la discontinuidad nos encontramos también con disociaciones y asociaciones entre diversas imágenes sobre los mayas. Me explico.

Obras como las de Stephens y Redfield van más allá de ser eventos originarios en la “invención” de la civilización y la cultura maya, como ha señalado Quetzil Castañeda (1996:109 y ss.). Con sus trabajos no sólo se ha gestado el "museo de la cultura maya", inscrito con tropos de "ciudades perdidas", "misterio" (caso de Stephens) y "progreso" (caso de Redfield) y que ha guiado la episteme de los estudios sobre los mayas así como las imágenes turísticas e imaginarios de los turistas que visitan la región (Castañeda 1996). En las discusiones con sus interlocutores también se han producido disociaciones y asociaciones de diversa índole entre los mayas antiguos y los mayas contemporáneos.

En el caso de la discusión entre Stephens y Sierra, encontramos una disociación entre los antiguos constructores de pirámides (que después representarían la categoría de civilización maya o la cultura técnicamente llamada maya) y los indios contemporáneos (que después serían representados como campesinos folk, mayas milperos y, posteriormente, como mestizos e indígenas). La imagen sobre la primera entidad, por lo general, ha sido positiva, epitomizada con adjetivos de grandeza. La segunda imagen es la que ha sido formulada, como observa Guzmán, a partir de imágenes de sumisión y pasividad ante la dominación, aunque no siempre (Stephens sí representaba a los indios como dóciles, pero Sierra O’Reilly como bárbaros belicosos). Así, junto con la invención de lo maya, también se reformuló la categoría de indios. El museo de la cultura maya continúa siendo una máquina productora de tropos de misterio sobre la primera entidad, pero sobre la segunda entidad se siguen "citando" discursos racistas decimonónicos, como ha observado Iturriaga (2010).

Y del mismo modo que Castañeda (1996) argumentó que el museo de la cultura maya funciona, en términos de Foucault, como un poder-saber, la otra categoría, la de indios, también implica un poder-saber. Las categorías étnicas no son naturales, su carácter histórico está preñado de relaciones de saber-poder con efectos múltiples (Foucault 1980; 2009:120 y ss.). Por ejemplo, el argumento de Stephens de que los indios contemporáneos carecen de tradiciones sobre las ruinas e incluso son indiferentes a ellas, justifica la 
apropiación patrimonial por parte del viajero norteamericano. Por otra parte, la caracterización de Sierra de los indios como bárbaros, no civilizados, justifica la asimilación de éstos, una asimilación que, como diversos estudios sobre el indigenismo han mostrado, no buscaba realmente una "feliz fusión de razas" (a propósito de una desatinada frase de Manuel Gamio [1982:13] sobre la población de Yucatán), sino que los indios se desindianicen. De igual modo, podía justificar la reacción violenta hacia estos indios bárbaros como respuesta a su sublevación en la denominada "guerra de castas".

Por otra parte, Redfield y Barrera Vásquez también produjeron disociaciones entre los mayas antiguos, arqueológicos, la cultura técnicamente llamada maya, y los contemporáneos campesinos folk y mayas milperos. En este momento ya comienza a usarse con mayor frecuencia la categoría "maya", prácticamente ausente en la discusión entre Stephens y Sierra. Resulta interesante constatar que en esta disociación intervenían intereses disciplinarios diferentes: Redfield legitimaba una antropología sociocultural del presente, distinta de la arqueología mayista, mientras que Barrera Vásquez trabajaba en una antropología integral, de marcada vocación boasiana. Como ha observado Castañeda, el progreso de los folk contemporáneos estudiados por Redfield iba muy acorde al discurso de la Carnegie. Por otro lado, la concepción sobre los mayas milperos que tenía Barrera Vásquez estaba articulada con sus políticas indigenistas. Díaz Bolio, en cambio, asoció ambas categorías como un primer elemento de reivindicación de la historia regional, no de la población maya en sí misma.

Es sólo en el tercer momento analizado que la tesis de la continuidad produce una asociación entre mayas antiguos y mayas contemporáneos. La continuidad ya no es tanto una respuesta a la construcción de una historia regional, sino un instrumento de reivindicación étnica. Se enmarca en un nuevo campo político, en el de las luchas de reivindicación y de reconocimiento por la diferencia.

A manera de recapitulación, en este capítulo hemos visto: los cambios en las tesis de la continuidad y la discontinuidad, de los actores que las promulgan y defienden, de los saberes y poderes que las sostienen y desafían, así como sus diversas implicaciones. He sostenido, también, que la tesis de la continuidad se ha constituido en un recurso de reivindicación étnica. Por último, he argumentado que en las discusiones revisadas se han gestado distintas categorías sobre la población indígena de Yucatán, unas objeto de 
valoración, otras de desprecio. Ahora cabe preguntarse, ¿cómo los indígenas yucatecos, conocidos en buena parte de la región como mestizos, se han convertido en mayas?, ¿hasta dónde ha llegado la mayanización?, ¿qué sucede con los indígenas no mayanizados? Los siguientes capítulos buscan respuestas a dichas interrogantes.

Como punto final de este capítulo, planteo que la tesis de la continuidad, o mejor dicho, ciertos usos sociales de ésta, pueden resultar peligrosos. Los antropólogos de origen sudafricano Jean y John Comaroff (2009) han registrado diversos casos en que se exigen como pruebas de continuidad étnica en África exámenes genéticos y muestras de ADN, y que dicha tesis ha sido empleada para excluir a individuos de etno-corporaciones y etnonegocios. He insistido en que ninguna de las tesis implica por sí mismos juicios de valor. No obstante, los usos enfáticamente comunitaristas y positivos de la tesis de la continuidad pueden sucumbir en el particularismo, en el relativismo y en la sofistica de la diferencia: "la exaltación de lo diverso puede convertirse en una prohibición de esa diversidad, ya respecto a los individuos que componen al grupo que reclama su derecho a la diferencia, ya respecto a otros grupos" (Díaz Cruz 2003:316). Y así como la tesis de la continuidad puede incurrir en peligros, la tesis de la discontinuidad no necesariamente conduce a juicios de valor negativos hacia la población indígena. Para ilustrar lo anterior recurro justo a la aseveración de un defensor de la tesis de la continuidad: "Antes, cada vez que hablábamos del pueblo maya, nos preocupábamos mucho en señalar su grandeza pasada, como asidero para justificar su derecho a seguir existiendo. Hoy hemos comprendido que este derecho es inalienable, independientemente de las grandezas o vicisitudes por las que ha atravesado e independientemente del tamaño del pueblo" (Alonzo 1993:43). Agregaría que no sólo no necesitamos aludir a un pasado grandioso, sino a cualquier continuidad con el pasado. Como ha observado Luis Reygadas (2008:337), las imágenes que idealizan a las comunidades indígenas y su continuidad con un pasado idílico no constituyen "un diagnóstico certero de la realidad indígena ni representa[n] una alternativa frente a la exclusión”. Pero sí funcionan, continúa Reygadas, como instrumentos para luchar en contra de la desigualdad y la exclusión. No obstante, considero que el derecho a la diferencia (así como el derecho a la igualdad) no debe necesariamente descansar sobre la tesis de la continuidad, so pena de excluir a quienes no se consideren o no sean considerados descendientes de la población originaria en cuestión. 


\section{La mayanización de los mestizos yucatecos: la problemática étnica Yucatán}

En la sección dedicada a "Los mayas yucatecos" del Museo Nacional de Antropología en Chapultepec, Ciudad de México, se puede leer en la placa introductoria: “A excepción de los kruso'ob, que se consideran descendientes de los mayas rebeldes de la 'guerra de castas' que tuvo lugar en la península, los mayas yucatecos se llaman a ellos mismos 'mestizos"'. En sintonía con esta apreciación, diversos estudiosos historiográficos y etnográficos han constatado que la población indígena en Yucatán no se identifica como "maya" sino como "mestizo", o bien, como "campesino", "mayero" (si habla la lengua maya) o como miembro de su comunidad de origen (Gabbert 2004; Gutiérrez-Estévez 1992; Hervik 1999; Mossbrucker 1992; Quintal 2005; Restall 1997). Estos estudios también han documentado cómo los mestizos yucatecos no sólo no se reconocen a sí mismos como mayas, sino que, para ellos, los mayas en realidad son otros, gente del pasado que construyó los monumentales edificios en Chichén Itzá, Uxmal, Tulum y otras zonas consideradas hoy arqueológicas.

Ante esta constatación inmediatamente emerge un caudal de preguntas. ¿Acaso el término mestizo es el término impuesto por la sociedad dominante?, ¿el término mestizo desplazó al de maya como una forma de identificación de la población indígena?, ¿el proceso de mayanización de los mestizos puede entenderse como una reivindicación del nombre propio u original, así como los eskimales se reivindican como inuit, los bosquimanos como san, los tarahumaras como rarámuri y los tarascos como

purépechas?, ¿se trata, para decirlo con palabras de Adam Kuper (2003), de un "retorno del nativo"? Me parece que no. Y que la lógica de argumentación que se encuentra detrás de este tipo de proposiciones podemos caracterizarla como el "argumento de la 
revitalización étnica", un vértigo argumental ante el que propongo ofrecer una alternativa analítica.

¿En qué consiste el argumento de la revitalización étnica? Éste postula que las identidades étnicas actuales son el resurgimiento, renacimiento o el despertar de identidades que ya existían en tiempos pasados (en ocasiones tiempos muy remotos), pero que en determinado momento fueron negadas, ocultadas o reprimidas. Es sólo ante condiciones más recientes que, parafraseando a Ernest Gellner (2008:125), dichas identidades despiertan sobresaltadas por el precioso beso de un príncipe azul, dejando atrás el largo período de sueño. A la luz de este argumento, la identidad étnica maya contemporánea sería el despertar de una adormecida identidad preexistente en tiempos prehispánicos.

No niego que el argumento de la revitalización étnica nos pueda explicar algunos casos de etnicidad contemporánea, pero sí sostengo que no explica la etnicidad maya en Yucatán, es decir, el proceso de mayanización de los mestizos yucatecos, y las reivindicaciones del Pueblo Maya en el estado. ¿Qué argumento ofrezco a cambio? Lo esbozo a continuación. En primer lugar, sostengo que el proceso de mayanización de los mestizos yucatecos es un fenómeno en esencia moderno (especialmente de los siglos XX y XXI), no el despertar de un fenómeno antiguo. Segundo, que dicho proceso de etnogénesis está vinculado con el poder: ha sido necesario el control de recursos y su expresión en órdenes clasificatorios simbólicos y en manifestaciones performativas.

De este modo, el presente capítulo está organizado de la siguiente manera. Primero, abordo el tema de la falta de una conciencia e identidad étnica en el momento de la conquista española en el siglo XVI y de las formas de identificación de los locales. En la segunda sección planteo el problema de las categorías étnicas en Yucatán y su relación con procesos políticos y económicos que han tenido impacto en la región. En el último apartado analizo la emergencia de actores que, a partir del control ciertos recursos y del cuestionamiento del orden clasificatorio simbólico hegemónico, manifiestan de manera performativa su mayanidad. Es decir, cómo estos mestizos se convirtieron en mayas.

Así, este capítulo me servirá para ubicar en un contexto histórico, sociocultural y político a los actores protagonistas de la investigación: sujetos que se identifican a sí mismos como mayas y que plantean reivindicaciones en nombre del Pueblo Maya. Como 
todo fenómeno sociocultural, se trata de un fenómeno también histórico, producto de diversos procesos sociales, políticos y económicos. Así, uno de los propósitos de este capítulo es desnaturalizar o desnormalizar lo que hoy en día puede parecernos natural o normal en cuanto al fenómeno étnico maya en Yucatán.

\section{El cah y el chibal}

En este apartado me remonto a los primeros años posteriores a la conquista de Yucatán. Mi objetivo no es propiamente el presentar una historia de las relaciones interétnicas durante los primeros años de la colonia en Yucatán, sino desarrollar mi crítica al argumento de la revitalización étnica así como analizar ciertos procesos étnicos de la época a la luz de las consideraciones teóricas sobre el poder, su expresión performativa y los intermediarios. Mi argumento central es que en el momento de la conquista no existía una identidad étnica maya o una conciencia étnica que abarcara a todos los maya hablantes de la península. Por lo tanto, resulta erróneo hablar de un "resurgimiento" de la identidad étnica maya en la actualidad. Asimismo, esbozaré la siguiente hipótesis: en el período colonial surgieron diversos intermediarios entre la Corona española y las comunidades indias (Cunill 2012). Algunos de ellos lograron controlar una serie de recursos que expresaron de manera performativa, pero no como una reivindicación del Pueblo Maya, sino como una reivindicación de sus linajes.

\section{Formas de identificación y estructuras políticas}

La conquista de Yucatán, iniciada en 1527, ha sido caracterizada por los estudiosos del tema como una "conquista ambivalente" (Clendinnen 2003), una "conquista inconclusa" (Bracamonte 2001) e, incluso, no como una conquista, sino como una "invasión" (Alonzo 1982), para manifestar que el proceso étnico de imposición española no es uno acabado. En este sentido, podemos apreciar que en el momento de la conquista española no sólo tuvieron lugar procesos étnicos de imposición o de supresión, sino también de resistencia, apropiación e innovación. Para comprender mejor estos procesos, hay que hacer referencia a las estructuras de poder entonces imperantes. Me permito una breve digresión. 
En la actualidad solemos hablar sin mayor dificultad de los "pueblos indígenas" e incluso referirnos a ellos como unidades sociopolíticas. En este punto bien valdría la pena recordar algunas de las enseñanzas de los antropólogos mexicanos indigenistas de mediados del siglo XX. Por ejemplo, a partir de su investigación entre comunidades zapotecas, Julio de la Fuente fue de los primeros en advertir que "la unidad étnica, social, religiosa y política entre los indígenas es el grupo municipal, en tanto que entre los ladinos la unidad está constituida por el grupo regional. Una unidad mayor que la comunidad, que pudiera abarcar los componentes de un grupo lingüístico o tribal, no se da en Mesoamérica" (Aguirre Beltrán 1989:12). Los individuos indígenas, observaba De la Fuente, se identificaban con su comunidad a partir de un marcado sentimiento de etnocentrismo, en vez de sentirse parte de un grupo étnico-lingüístico más amplio o de la nación (De la Fuente 1989a; 1989b). En Formas de gobierno indigena, una de las obras pioneras de la antropología política en México, Gonzalo Aguirre Beltrán se sirvió de las observaciones etnográficas de De la Fuente, además de las suyas en los Altos de Chiapas, Michoacán y la sierra Tarahumara en Chihuahua, para postular que, lo cito in extenso:

En el país no existen en la actualidad una o dos centenas de grupos étnicos organizados, como pudiera suponer la recopilación censal de un número igual de idiomas diferentes; lo que realmente se encuentra es la presencia de una o dos decenas de millar de comunidades indígenas independientes. Pueden muchas participar, y de hecho participan, de una cultura común y de una lengua con variaciones dialectales de poca monta; mas no obstante ello cada comunidad, misticamente ligada a su territorio, a la tierra comunal, constituye una unidad, un pequeño núcleo, una sociedad cerrada que a menudo se halla en pugna y feudo ancestral con las comunidades vecinas de las que, siempre, se considera diferente.

El individuo que forma parte de tal comunidad no siente que pertenece a la comunidad, sino a su linaje y a la tierra del linaje. No tiene conciencia de ser sólo fragmento de un grupo étnico (Aguirre Beltrán 1991a:16).

Lo mismo vale para la época precortesiana, advierte Aguirre (1991a:17):

Las denominaciones de nación mexicana, imperio maya, reino mixteco, impuestas a las estables e inestables agrupaciones de comunidades indígenas fueron francamente equivocadas, porque suponían un sentimiento cuya existencia quedó desmentida en el momento mismo de la Conquista, realizada con una facilidad extraordinaria. Las 
resistencias que encontraron los españoles, a lo largo del país y de norte a sur, provinieron de comunidades aisladas, nunca de la totalidad de los grandes grupos étnicos.

¿Por qué detenerse en textos y postulados indigenistas de mediados del siglo XX? Porque me parece que, como muchos textos clásicos, pueden ofrecernos valiosas lecciones para el presente. En primer lugar, nos ayuda a cuestionar la idea, por lo general dada por sentada, de que existe y ha existido el "Pueblo Maya" como una unidad sociopolítica y referente identitario. No quiero decir, empero, que el "Pueblo Maya" sea una ficción o una mera invención. Mucho menos niego el derecho a la diferencia de quienes se identifican con el Pueblo Maya. En la actualidad existe como categoría ideal y simbólica y, como tal - como un "símbolo dominante" podríamos decir - , sirve de referente para la acción. Con esto en mente, pasemos a las estructuras políticas en Yucatán en la Colonia.

Con respecto a lo anterior, la investigación etnohistórica de Matthew Restall (1997), inspirada en la "nueva filología”, resulta reveladora. El principal argumento de Restall es que entre los mayas de la colonia la identificación y pertenencia se daba principalmente a nivel del Cah (comunidad) y el Chibal (grupo patronímico exógamo); no había una unidad sociopolítica e identitaria, algo así como "el Pueblo Maya". ${ }^{61}$ Estas formas de organización sociopolítica son claves para que podamos entender el proceso de conquista y colonización de Yucatán, pues no actuó un grupo étnico (el maya) en contra de otro (el hispano), sino que algunas entidades políticas se aliaron con los conquistadores, mientras que otras opusieron resistencia. Del mismo modo, las entidades

\footnotetext{
${ }^{61}$ Restall no sólo apunta que no existía el "Pueblo Maya" como unidad sociopolítica, sino que el mismo término "maya" no se empleaba para designar personas. A partir de la revisión de actas notariales, señala que el término se usaba siempre en referencia a la lengua, en la forma de maya than (habla maya), aunque también era común referirse a la "lengua yucateca". Ocasionalmente aparecía como un adjetivo de un objeto material. El punto clave, continúa Restall (1997:14), es que el uso del término no sólo fue raro como una designación étnica, sino que era aún más raro que fuera empleado como término de auto-adscripción. Por su parte, Gabbert también advierte que el término maya se emplea principalmente para referirse a la lengua. Ni siquiera se refería a la lengua de toda la península, ya que encontramos algunas variaciones lingüísticas regionales: en el norte, la maya 't'an, en los alrededores de Campeche la kampech t'an, en el sur extremo la putun t'an y en el sudeste la lengua de uaymil (Gabbert 2004:29). El término "maya" hacía referencia a la variación lingüística del norte de la península, donde gobernaba Mayapán. Así, los habitantes de Chikinchel (Emal), así como quienes pertenecían al linaje Ah Canul, por ejemplo, no eran mayas (Gabbert 2004:30).
} 
políticas mayas se encontraban jerarquizadas en clases: por un lado, la elite almehenob; por otro, los comuneros macehualob, amén de una proporción de población esclava.

Por su parte, el historiador Sergio Quezada (1993) se ha detenido en el estudio de la organización política en Yucatán en el momento de la conquista, mostrando que después de la hegemonía de los Itzáes en Chichén Itzá y de la confederación de Mayapán (sitio gobernado por los Cocom), en la península gobernaban diversos cuchcabaloob y bataboob. El cuchcabaal era una entidad político-territorial gobernada por un gran señor (el halach uinic) compuesta por tres niveles: primero, el cuchteel, la unidad básica conformada por grupos de familias extensas; el segundo era el batabil, usualmente integrada por tres o cinco cuchteel, y en donde el poder era ejercido por el batab o cacique; y el tercero era propiamente el del cuchcabaal, en donde el poder lo ejercía el halach uinic. Tanto el halach uinic como el batab formaban parte de la clase noble almehenob, y podían pertenecer a chibaloob (linajes) distintos. Así, en el momento de la conquista, los españoles se encontraron con cerca de dieciocho cuchcabaloob, amén de un buen número de batabiloob.

Por lo tanto, el proceso de contacto español-maya hay que entenderlo no como el contacto entre dos grupos étnicos, sino como la interacción entre un grupo colonizador con diversas entidades políticas, linajes y comunidades, todas ellas jerarquizadas a su interior. Así, por ejemplo, algunos miembros del chibal Xiu, uno de los más poderosos de la región, estableció alianzas con los españoles; algo semejante sucedió con el chibal Pech en el sur de la región. Por otro lado, los Cocom de Sotuta opusieron una acentuada resistencia hacia los españoles. De este modo, para algunos linajes y comunidades, el dominio colonial continuó y reforzó relaciones de desigualdad social antes imperantes, pero para otros ofreció las oportunidades de perpetuar y obtener nuevos privilegios sociales, políticos y económicos (Restall 1997:5; Gabbert 2004:8-9). ${ }^{62}$

¿Cómo entender, a la luz de los argumentos de Restall y de Quezada, los procesos étnicos imperantes durante la Colonia? Restall argumenta que la población hispana, en tanto en condición de minoría, pudo haber desarrollado cierta conciencia étnica y emplear

\footnotetext{
${ }^{62}$ Entre los privilegios que la nobleza india pudo gozar gracias a sus alianzas con los españoles se encuentran: estar exentos del tributo, trabajo forzado y de las prohibiciones legales impuestas a los indios comuneros, podían portar una espada y daga y usar vestido europeo, emplear el título de don e incluso montar caballos (Gabbert 2004:19).
} 
categorías étnicas o raciales para clasificar a la población (plasmadas en el sistema administrativo de repúblicas de indios). Es decir, los españoles pudieron haber visto al conjunto de cahob y chibalob de la región como un solo grupo: los indios. ${ }^{63}$ Pero eso no significa que los nativos de Yucatán compartieran las mismas categorías, o que éstas tuvieran connotaciones étnicas. ${ }^{64}$ Una categoría que hoy es considerada étnica, la de $d z u l$, refería a los españoles pero también para aludir a los habitantes del centro de México. Para Restall, la auto-definición de los nativos de Yucatán no era en términos étnicos sino de clase: de una sociedad dividida entre los almehenob (los nobles) y los macehualob (los comuneros) (Restall 1997:16). Así, el "mundo maya", la concepción de los nativos de Yucatán, estaba determinada principalmente por el cah, el chibal y la clase. No existía una identidad étnica maya. Restall (1997:315) concluye que:

The cah was the Maya community. More than just a pueblo or town, it was the primary sociopolitical unit of the Maya, consisting of both a residential core and dispersed parcels of land held by the community and its members. More than just a geographical or organizational unit, it was the focus of Maya self-identity. A Maya who was to the Spaniards a mere "indio" was to his own people a "cahal", a resident and member of a particular cah. He or she was also a member of a particular patronym group or chibal, but the importance of each chibal was localized, determined not regionally but by cah. In spite of the existence of cahob tied to neighboring units or to Spanish municipalities what I have termed complex cahob- and in spite of the existence of the cah-to-cah variations that are in evidence in almost every chapter, the centrality of the cah and its common characteristics throughout the province of Yucatan helped allow this study to embrace most of the region for a time period roughly corresponding to the colonial era.

\footnotetext{
${ }^{63}$ Recuérdese en este punto el célebre artículo de Guillermo Bonfil (1972) donde argumenta que la categoría "indio" es producto del sistema colonial y, en tanto tal, pasó por alto la diversidad étnica.

${ }^{64}$ Así, por ejemplo, para los mayas, un conjunto de cah, de comunidades, conformaban un cahob, mientras que para los españoles tal conjunto conformaba una república de indios (Restall 1997:24). El énfasis español en categorías étnicas fue fuertemente resistido por los mayas, evidenciado en el uso limitado de Maya como un término étnico así como en la importancia de las profundamente enraizadas categorías no étnicas de identidad y descripción. El hecho de que esas categorías — cah y chibal- tuvieran connotaciones étnicas después de la conquista no refleja una continuidad o profundidad de la consciencia étnica maya sino las limitaciones racistas de un sistema colonial que impuso dicha consciencia mientras paradójicamente fomentaba su debilidad ofreciendo movilidad social parcial a aquellos que colaboraban económica o biológicamente con los colonizadores (Restall 1997:15).
} 
Intermediarios, control de recursos y narrativas performativas

Fue a este "mundo maya", definido por los cahob y los chibalob, al que se enfrentaron los españoles y sobre el que establecieron la administración colonial, cuya economía se basaba en la tributación, los repartimentos y los servicios personales que impusieron, por lo demás de manera diferenciada, a los indígenas (Bracamonte 1994). Como ha observado Quezada (1993), tras la supresión de los cuchtabaloob por parte de los españoles, los bataboob funcionaron como un actor central, de hecho, como un intermediario entre el gobierno español y la comunidad indígena. Pero no fueron los únicos intermediarios.

Hay que recordar que en Yucatán, el suelo, dada su pobreza, no funcionó como un recurso significativo a controlar. No así la energía humana materializada en la fuerza de trabajo. Las élites almehenoob ejercieron poder a partir del control de la fuerza de trabajo india, amén de otros recursos como los conocimientos sagrados, las fuentes de agua, entre otros. Pero, como han observado diversos estudiosos, tras la implementación del sistema colonial, los frailes franciscanos conformaron el grupo más poderoso de Yucatán durante los primeros años posteriores a la conquista (Lentz 2008:143). Y en este marco podemos entender el surgimiento de diversos intermediarios entre la Corona, el poder de los franciscanos y las comunidades indígenas. Por ejemplo, para limitar el poder de los frailes, la Corona española creó el Juzgado Privado de los Indios de Yucatán, en donde los intérpretes generales ocuparon un puesto muy destacado como intermediarios, limitando el poder de los frailes y ofreciendo a los indígenas nuevos recursos (Lentz 2008:143). Como ha observado Lentz (2010), contar con intérprete es un "privilegio legal observado con más regularidad en el siglo XVIII que en el XXI" (Lentz 2010:2). ${ }^{65}$ Otro grupo de intermediarios fueron los indios educados por los frailes franciscanos, sobre los cuales deseo detenerme ahora.

Atendamos a un proceso étnico colonial que podría caracterizarse como de “imposición” (Bonfil 1991): la alfabetización con fines de evangelización. ${ }^{66}$ La

\footnotetext{
${ }^{65}$ A partir de la figura de los intérpretes, Lentz cuestiona una idea predominante en la historiografía del Yucatán colonial, la de una "segregación rígida entre la mayoría indígena y la minoría española" (Lentz 2008:137).

${ }^{66}$ La orden seráfica se estableció de manera definitiva en la provincia de Yucatán a finales de 1544. En su establecimiento tuvo un papel de primer orden fray Luis de Villalpando, acompañado de fray Melchor de Benavente, fray Juan de Herrera y fray Lorenzo de Bienvenida (Cunill 2008:169-170)
} 
investigación etnohistórica de Caroline Cunill (2008) nos muestra que la alfabetización de los franciscanos en Yucatán no debe entenderse únicamente como un proceso de imposición, pues la población local estuvo interesada en la adquisición de la alfabetización para poder preservar su propia cultura. La escritura de los mayas, de tipo "grafemática-logográfica" (compuesta de glifos), era considerada sagrada, pues era una forma de conservar la memoria de los acontecimientos, así como un sinónimo de poder y de prestigio: eran sobre todo los ah k'ines (los sacerdotes) quienes escribían (Cunill 2008:166). Así que junto al proceso de imposición se gestaron unos de resistencia, innovación y sobre todo de apropiación. Estos procesos hay que entenderlos a la luz de estructuras de poder.

Debido a la escasez de religiosos en América, los franciscanos (como ya se mencionó, el grupo más poderoso en los primeros años de la Colonia) tuvieron que delegar el ejercicio del poder a algunos actores indígenas, por ejemplo, las tareas en torno a la evangelización. Así, los franciscanos y los sacerdotes mayas llegaron a acuerdos para la enseñanza en las comunidades indias. ${ }^{67}$ A quienes se les impartiría instrucción religiosa sería a los hijos de los bataboob (caciques) y principales indios, quienes a su vez seguían dirigiendo a los macehualoob. Se trataba de formar a "maestros de escuela", una especie de ahkines modernos. A partir de esta delegación de poder, los indios pudieron ejercer el control sobre un recurso o elemento cultural: la escritura.

A partir de los procesos de alfabetización, las elites indias no sólo ejercieron control sobre nuevos recursos, como el de la escritura, sino que su posición estructural también cambió, ya no se ubicaban en la posición dominante dentro de la estructura social, sino que los caciques y ahkines ejercían relaciones de intermediación entre los frailes y los indios de los pueblos de indios (Cunill 2008:177, 180; Quezada 1993). Aún más, el control del recurso de la escritura tuvo efectos no deseados para los evangelizadores. Por ejemplo, por medio de la redacción y envío de cartas, los maestros de escuela jugaron un gran papel en la comunicación y mantenimiento de lazos sociopolíticos entre los pueblos de indios, es decir, comenzaron a usar de manera

\footnotetext{
${ }^{67}$ Pero el proceso no fue del todo armónico. Como observa Cunill (2008:176), los juicios inquisitoriales de Maní de 1562 pusieron de relieve la participación masiva de los maestros de escuela en las ceremonias de corte prehispánico, Diego de Landa, en 1562, acusa a los caciques y a los maestros de escuela de idolatría.
} 
autónoma la escritura alfabética (Cunill 2008:179). ${ }^{68} \mathrm{Si}$ bien en un principio fueron principalmente los maestros de escuela los que aprendieron a leer y escribir, con el paso del tiempo cada vez más caciques se alfabetizaron (Cunill 2008:185)

Uno de los usos "autónomos" (Bonfil 1991) más notable del control de la escritura por parte de las elites indias fue el de escribir las historias de sus grupos de origen. ¿Se trataba ya, desde aquel entonces, de una reivindicación del "Pueblo Maya"? Parece que no. Era, ante todo, la reivindicación de sus propios linajes. Como ha observado el historiador Tsubasa Okoshi (2001), la nobleza maya yucateca empleó los caracteres latinos para escribir documentos legales con el fin de obtener el reconocimiento de la hidalguía de su filiación prehispánica, así como textos de carácter histórico, como los Libros de Chilam Balam, en donde, sobre todo, alaban "su propio linaje ante los europeos para gozar de ciertos privilegios en el nuevo régimen" (Okoshi 2001:213). Dichas historias, siguiendo con Okoshi, pueden considerarse mitos de origen en donde las elites alfabetizadas narran, de manera ciertamente dramática (es decir, performativa), la historia de sus linajes, historias por lo demás llenas de episodios de migraciones y gloriosas batallas; historias presentadas de acuerdo a un patrón cíclico, en donde se enfatiza la importancia simbólica de los lugares de origen, ubicados en el poniente, en donde se pone el Sol, es decir, la entrada al inframundo, un lugar donde, como "centro simbólico" (Geertz 1994), se "obtiene el poder, la energía y la sabiduría" (Okoshi 2001:220), en donde se transita por el inframundo. Así, miembros educados de linajes como los Xiu, los Canul y los Itzáes

hablaban simbólicamente de lo que experimentaron en el inframundo: una muerte, varias pruebas a vencer, la obtención de sabiduría y el posterior renacimiento con el poder legítimo. La intención de los escribas mayas que registraron tal historia, por ende, era demostrar tanto a sus contemporáneos como a sus sucesores la legitimidad cósmica del poder que ejercían los sitios elegidos como su sede político-ceremonial (Okoshi 2001:221).

\footnotetext{
${ }^{68}$ También se dieron otros efectos imprevistos, ya que algunos caciques no enviaron a sus hijos, sino a criados o a esclavos, quienes recibieron la enseñanza de los frailes, y llegaron a obtener puestos de responsabilidad que no hubieran tenido en la anterior estructura social (Cunill 2008:180). la clase dirigente llegó a ser despojada de sus antiguas funciones
} 
De este modo, a través de sus historias, los Xiu, los Canul y los Itzáes se presentan "como creadores del mundo", como "representantes del orden cósmico, con la finalidad de legitimar su poder ubicándolo dentro de la cosmovisión y cosmogonía mayas" (Okoshi 2001:222). Y tenían que legitimarse de tal forma ya que estos tres linajes eran considerados “"extranjeros” para los mayas yucatecos, razón por la cual tuvieron que describir concreta y enfáticamente cómo llegaron a obtener el poder político y religioso en tierras ajenas a ellos" (Okoshi 2001:223). Resulta por lo demás interesante que algunos de los grupos que hoy consideramos sin mayor vacilación como "mayas", tales como los Itzá o los Xiu, ${ }^{69}$ fueron considerados $t s^{\prime} u l o o b$ (foráneos) por sus rivales políticos, como los Cocom (Gabbert 2004:32; ver también Barrera Vásquez y Rendón 1985).

Así las cosas, podemos convenir con Gabbert (2004:27), quien sostiene que los Libros de Chilam Balam no cuentan la historia "nacional" de "los mayas", sino que son intentos de diferentes linajes nobles de legitimar sus posiciones de prestigio y poder. La referencia no es el grupo étnico, sino los grupos de parentesco gobernantes. Y, de hecho, los masehualoob casi no aparecen en los textos.

En síntesis. Hemos visto que en el momento de la conquista y durante los primeros años de la colonia no existía el pueblo maya como una unidad sociopolítica ni una conciencia étnica que abarcara a todos los hablantes del maya yucateco. La estructura política estaba conformada por entidades políticas gobernadas por linajes (chibalob) nobles, y las principales unidades sociopolíticas eran las comunidades (cahob). Ante tal estructura política, y ante la falta de religiosos españoles que pudieran evangelizar, los frailes franciscanos tuvieron que delegar poder a las elites mayas, con lo que éstas ejercieron el control de un recurso significativo: la escritura. El control de este recurso se manifestó de diversas formas, y una de ellas fue particularmente performativa: la narración de mitos de origen e historias de bronce de los linajes de las elites, de formas de presentarse ante los españoles con el fin de legitimar su poder. Pero no se trataba de la reivindicación del "Pueblo Maya", sino específicamente de sus linajes.

${ }^{69}$ Tómese como botón de muestra la siguiente declaración de una intelectual maya contemporánea a propósito del origen de los mayas: "Es triste decirlo, pero en la actualidad muchos mayas no saben de dónde provienen. Sin embargo, el mestizaje es algo extraño a nosotros porque tenemos la historia de nuestro propio origen. Por los registros de Chichén-Itzá sabemos que descendemos de los Xiu, quienes llegaron de algún lugar del centro" (en Gutiérrez Chong 2001:200). 
Procesos de modernización, variaciones regionales y categorías étnicas

Quiero detenerme en este punto en la hipótesis de Gabbert (2004) de que en Yucatán no existen dos grupos étnicos claramente delimitados pero sí un sistema de categorías étnicas que funciona de manera relativa, situacional y de acuerdo a variaciones regionales. Su hipótesis resulta sugerente, pues nos ayuda a evitar sucumbir en dos vértigos argumentales: uno que postula la existencia de la identidad étnica maya para todos los maya hablantes de la península, el otro que la niega rotundamente.

Siguiendo la hipótesis de Gabbert (2004), en este apartado revisaré brevemente dos procesos regionales que han tenido un impacto considerable en el sistema de categorías étnicas en la península: el conflicto conocido como "guerra de castas" y el desarrollo de la hacienda henequenera. Asimismo, abordaré el proceso de modernización en algunas regiones del estado, el cual dio lugar a un "cambio étnico" en el que los mestizos se estaban desindianizando. Un proceso que se invertirá más adelante como veremos con la mayanización de los mestizos yucatecos.

Variaciones regionales y procesos étnicos: la guerra de castas y la hacienda henequenera

Los estudiosos de Yucatán han identificado diversas regiones geográficas y económicas en el estado: la zona henequenera en la parte central y noroccidental de la entidad (la cual cubre el 34\% de la superficie total); la región sur agrícola y hortocitrícola; la región milpera del oriente; así como la región ganadera del noreste (Quintal et al. 2003; Ramírez 2002). Estas diferencias "regionales" no pueden entenderse exclusivamente en términos locales: están claramente articulados a procesos globales, por ejemplo, la demanda de henequén por parte de los Estados Unidos fue clave para la conformación de la región noroccidental. Examinemos brevemente dos de estas regiones: la oriente milpera y la noroccidental henequenera.

\section{Región oriente. La guerra de castas y los procesos de etnogénesis}

Sin duda, uno de los episodios que más ha marcado la historia de la población indígena en Yucatán es el conflicto conocido como "guerra de castas", iniciado en julio de 1847 y 
finalizado, si bien de manera parcial, en $1853 .^{70}$ Algunos estudiosos han argumentado que en realidad no se trata de un conflicto étnico, es decir, de una guerra entre "los mayas" y "los españoles". Por un lado, los rebeldes estaban en contra de la elite local, no de todos los "vecinos" o "blancos", al mismo tiempo que los actos violentos no fueron cometidos exclusivamente por indios (Gabbert 2004:48). Por otro lado, los maya hablantes de clase baja del norte y occidente de la península, por lo general, no apoyaron a los rebeldes, e incluso lucharon del lado del gobierno. ${ }^{71}$ Del lado de los rebeldes hay que considerar la importante presencia de "vecinos", entre los que destaca José María Barrera, uno de los fundadores del culto de la cruz parlante. Asimismo, los rebeldes se referían a sus adversarios justo como "enemigos" (enemigoo'b), y se designaban a ellos mismos con los términos cristianoo'b, otsilo'b (pobres) o masewalo'b. El término kruso'b aparecía sólo rara vez. Aún más, los rebeldes no se proponían exterminar a la raza blanca ni demandaban derechos especiales para los indios, sino derechos iguales para todos los ciudadanos, como la supresión del impuesto de capitación, de las contribuciones religiosas y otros honorarios (Gabbert 2004:53-55). Fueron sobre todo los miembros de la elite política e intelectual, como Miguel Barbachano o Justo Sierra $\mathrm{O}^{\prime}$ Reilly ${ }^{72}$, quienes presentaron el conflicto en términos de una guerra racial.

Sin embargo, la mayoría de los estudiosos coinciden en que la guerra de castas sí tuvo un impacto en el proceso de etnogénesis, a tal grado de dar lugar a un nuevo grupo étnico, los macehualoob cruzoob, es decir, los indios que se reconocen como descendientes de los rebeldes y que adoran a la cruz parlante (Quintal 2005:366). ${ }^{73}$ Este grupo, conocido también como los sublevados bravos, continuó peleando en contra del gobierno y permaneció fuera de su control hasta bien entrado el siglo XX (Gabbert 2004:57). De acuerdo con Gabbert, la represión de las tropas yucatecas que atacaron sus establecimientos y destruyeron sus campos jugó un rol significativo en la emergencia de

\footnotetext{
${ }^{70}$ En este apartado no puedo abordar de manera exhaustiva el tema de la guerra de castas. Para los interesados en el tema, remito a Reed (1964); Rugeley (1996)

${ }^{71}$ Gabbert (2004:53-54) nos ofrece los siguientes datos. En 1848, 10, 000 de 25, 000 hombres luchando en contra de los rebeldes pertenecieron a este grupo, conocido como "hidalgos".

${ }^{72}$ Como vimos en el capítulo anterior, Sierra (1994) planteaba una discontinuidad entre los antiguos constructores de pirámides y los indios actuales. Para él, los contemporáneos eran unos bárbaros fieros que odiaban a la raza española, de ahí su explicación de la guerra de castas.

${ }^{73}$ Después del momento más intenso y violento del conflicto, algunos de los rebeldes migraron hacia el sur y se constituyeron en el grupo conocido como los "pacíficos del sur", hasta que se integraron al estado de Campeche y desaparecieron como un grupo distinguible (Gabbert 2004:57).
} 
una conciencia étnica entre los rebeldes y sus descendientes. El culto religioso de la cruz parlante fue otro elemento clave que fomentó la cohesión entre los rebeldes (Gabbert 2004:58). ${ }^{74}$ Así, como ha observado Paul Sullivan, para los descendientes de los mayas rebeldes, la guerra de castas aún forma parte de su presente y es constitutiva de su identidad (Sullivan 1991:179). A partir de esta memoria, los macehualob cruzoob se distinguen claramente de los yucatecos y de los mexicanos (Sullivan 1991:208).

Los cruzoob, particularmente los habitantes de Tusik, fueron los protagonistas de la célebre etnografía de Alfonso Villa Rojas, Los elegidos de Dios, y este material etnográfico sirvió a su vez para la teoría del continuum folk-urbano de Robert Redfield (1944). ${ }^{75}$ Recordemos brevemente que Redfield estaba interesado en conocer el proceso de evolución de la civilización humana. A diferencia de los estudios de los evolucionistas decimonónicos, que investigaban la evolución humana a través de la historia, a Redfield, Yucatán le parecía un laboratorio privilegiado para analizar dicho proceso en vivo, pues creyó encontrar en la península tanto tribus primitivas (entre ellas Tusik) como centros urbanos civilizados. En realidad, Redfield sucumbió en una falacia, pues consideró que la actitud hostil de los cruzoob de Tusik, así como su forma de organización, era esencialmente similar a la situación de los mayas en el momento del primer contacto con los españoles: “Tusik nos proporciona el ejemplo más próximo a la situación que existió inmediatamente después de la Conquista, cuando los indios eran distintos, cultural y racialmente, y en muy alto grado miraban a sus conquistadores como un grupo muy distanciado de ellos. Mérida, en el otro extremo, representa el resultado de cuatro siglos de interacción" (Redfield 1944:85-86). Pero, como hemos visto, tanto las actitudes de los cruzoob como sus formas de organización respondieron a procesos históricos del siglo XIX, específicamente a la guerra de castas.

\footnotetext{
${ }^{74}$ Se establece continuidad principalmente con los macehualob rebeldes, aunque también reconocen cierta continuidad con los constructores de pirámides. Escribe Sullivan (1991:104): "Los mayas han creído que esos predecesores [los constructores de pirámides], donde quiera que estén, viven y aguardan el momento del retorno. Chichén Itzá parecía una morada probable para esos seres misteriosos, y los mayas hablan de un rey durmiente que reside allí hasta hoy".

${ }^{75}$ En Yucatán, encontramos el culto a "Cruz Tún” (cruz maya de pidera), en torno a la cual se aglutinan en peregrinaciones sucesivas aproximadamente 50 comunidades de Yucatán y Quintana Roo. La cruz se encuentra en Xocén, Valladolid, Yucatán, lugar que es considerado como el "centro del mundo" por los mayas; se sabe que tiene relación con la de Tixcacal, Quintana Roo, lo que equivale a decir, con la guerra social de 1847. En los últimos años han ido en aumento las peregrinaciones. Alonzo interpreta este proceso como uno de los principales en la recuperación de la consciencia étnica maya (Alonzo 1993:49-50).
} 
Con todo, Redfield nos ofrece datos interesantes sobre los sistemas clasificatorios étnicos en Tusik. En el momento del estudio de Villa Rojas y Redfield, en esta "tribu" operaba una distinción clasificatoria entre los macehualob, que son el "nosotros", todos los que viven en el territorio, y los dzulob, que son los "otros", los que viven en las villas y en la ciudad. Hay una clara distinción entre el nosotros y los otros, y a los segundos se les atribuye un carácter de peligro y un estatus inferior. En cambio, en la comunidad campesina de Chan Kom, si bien también opera la categoría macehualob, no hay una línea claramente definida entre nosotros y los otros, pues las relaciones con los $d z u l o b$ son más amistosas, frecuentes e íntimas a comparación de Tusik. Entre los macehualob de Tusik se aprecia entonces una conciencia e identidad étnica, pero de este caso no nos es dable generalizar la existencia de una conciencia étnica en toda la península, ni que todos los maya hablantes se identifiquen como los descendientes de los rebeldes que participaron en la guerra de castas. Como ha observado Mossbrucker (1992), en algunas zonas conurbadas de Mérida los maya hablantes pobres no se identifican con la guerra de castas en lo absoluto y, aún más, la evalúan de manera negativa como un suceso violento y sangriento.

\section{Región noroccidental: la hacienda henequenera y lor procesos de desindianización}

El continuum folk-urbano de Redfield no sólo dictaba que el proceso de aculturación en la península estaba gestando procesos de individualización, secularización y desorganización de la cultura. También estaba transformando la estructura social: de la existencia de dos grupos claramente separados étnicamente, a una sola sociedad que, si bien estaba dividida en clases, era de carácter abierto y permitía la movilidad social de sus integrantes. ${ }^{76}$ Ciertamente, desde la perspectiva de Restall (1997), resulta cuestionable la aseveración de Redfield de que "al principio hubo dos sociedades separadas, distintas étnicamente [y que] Ahora hay una sociedad única, con clases, y sin diferencias étnicas" (Redfield 1944:85). Pero los datos de Redfield, especialmente aquellos sobre Mérida (la ciudad de su continuum) y Dzitás (la villa de su modelo), dan cuenta de una identificación más en términos de clase que étnicos.

\footnotetext{
${ }^{76}$ El proceso de la Revolución contribuyó de manera importante a la transformación de una sociedad de castas a una de clases, a quitar el gobierno municipal "de manos de los vecinos" y ponerlo "bajo el control de los indios" (Redfield 1944:98)
} 
Con todo, nuevamente podemos advertir que los procesos étnicos se entienden mejor de acuerdo a procesos económicos y políticos a nivel regional que por el simple proceso de aculturación entre la población descendiente de los españoles y la descendiente de los mayas. En este sentido, la identificación en términos de clase por parte de los maya hablantes de la zona noroccidental debe entenderse a la luz del desarrollo de la hacienda henequenera en el estado. ${ }^{77}$

La hacienda henequenera de Yucatán comenzó su periodo de auge hacia mediados del siglo XIX. En 1830 se estableció la primera plantación comercial de henequén y la industria se expandió rápidamente en las décadas siguientes. Un momento significativo fue cuando en 1878 la engaviladora McCormik en los Estados Unidos comenzó a utilizar la fibra del henequén, lo que aumentó considerablemente su demanda (Bartolomé 1988:263-264). Tras varias transformaciones (desde la formación del Gran Ejido Henequenero hasta la creación de la paraestatal Cordemex), la industria henequenera comenzó a resquebrajarse al terminar la Segunda Guerra Mundial. Entre otros factores, el desarrollo de las fibras sintéticas así como la emergencia de Brasil en este mercado fueron sucesos clave. Así, de 115 mil toneladas producidas en 1970, para 1985 se tenía una expectativa de producir sólo 5 mil (Bartolomé 1988: 274).

En este punto resulta pertinente traer a colación la tesis del sociólogo Othón Baños (1989), quien sostiene que los productores de henequén en Yucatán no pueden ser considerados campesinos en sentido estricto, pero tampoco proletarios. Más bien, argumenta, se tratan de ejidatarios, cuyas demandas principales no giran en torno a las tierras, sino en obtener créditos del estado. En una línea semejante, la politóloga norteamericana Shannan Mattiace (2009 y 2013) ha argumentado que la naturaleza del trabajo en la hacienda e industria henequenera, así como la intervención del Estado en esta última (que ha permitido poca autonomía bajo el régimen corporativista), es un factor clave en la falta de una conciencia étnica entre los maya hablantes de esta región. En su trabajo encontramos de nuevo que las principales demandas de los trabajadores de henequén son salarios más altos, la obtención de bonos y de créditos, y no de tierras

\footnotetext{
${ }^{77}$ En buena medida, esta idea se basa en la crítica de Strickson (1965) al modelo de Redfield.
} 
(Mattiace 2009:16). ${ }^{78}$ Esta falta de demandas por las tierras en Yucatán ha sido documentado también por Rosales y Llanes (2003). Veamos ahora cómo operan las categorías étnicas en la región.

Redfield observó que en la villa de Dzitás, las categorías que se emplean son la de mestizos por un lado, y gente de vestido o catrín, por otro. Se trata de una distinción que opera de acuerdo con el criterio de la indumentaria. Pero para las personas mayores de la villa el criterio que realmente distingue a los unos de los otros es el patronímico. Observa Redfield:

Un hombre, especialmente un anciano, puede tener una piel muy obscura, hablar solamente el idioma maya, vivir en un pobre jacal en las afueras de Dzitás, usar los pantalones blancos y el delantal rústico tradicional y, sin embargo, por el solo hecho de tener un apellido español, se siente superior a sus prójimos que tienen nombres mayas (Redfield 1944:94).

En el caso de Mérida, el polo urbano del continuum, la distinción básica era entre la clase alta, la "gente decente" o "gente de categoría", y una clase baja dividida entre quienes portaban apellidos mayas y quienes portaban españoles. Pero en la actualidad, observa Redfield, la distinción de apellidos tiene poca o ninguna importancia. Las diferencias son ahora de clase: ricos, clase media y pobres. Se trata de una sociedad abierta de clases en la que es posible la movilidad social ascendente. En Mérida "el papel de la raza en la definición de las clases ha disminuido en tal forma que ya ha desaparecido prácticamente" (Redfield 1944:103). Así, de acuerdo con Redfield, los meridianos consideran que existen indios, pero no en la ciudad, sino "allá en los pueblos" (Redfield 1944:103).

A partir del estudio de Tusik, Chan Kom, Dzitás y Mérida, Redfield concluyó que en todo Yucatán opera una clasificación ideal compuesta de dos grupos: uno urbano socialmente superior o dominante, de piel clara, asociado con el idioma español y los apellidos españoles, y otro grupo, rural, socialmente inferior, subordinado, de piel oscura, asociado con el idioma y apellidos mayas. Pero estos grupos no se distinguen claramente

${ }^{78}$ Este no es el único factor explicativo que considera Mattiace. Junto al carácter proletario de los campesinos yucatecos, se encuentra también el fuerte conservadurismo de la iglesia católica en Yucatán y que las ONG relacionadas con temas de derechos humanos y derechos indígenas tienden a operar a pequeña escala (Mattiace 2009). 
y con facilidad. Aún más, esta clasificación ideal de dos grupos se manifiesta a través de variaciones clasificatorias locales, pues ya vimos que, para los habitantes de Mérida, los indios son los de los pueblos. Pero si bien los habitantes de un pueblo como Dzitás pueden ser considerados todos indios por los de Mérida, ellos mismos podrían no considerarse indios. ${ }^{79}$ Del mismo modo, diacríticos como el apellido, el vestido o la lengua no funcionan en todas partes como signo de distinción. ${ }^{80}$

Redfield interpretó las variaciones clasificatorias étnicas en un marco evolucionista y teleológico. Como ya he apuntado, el polo urbano del continuum de Redfield no sólo es el lugar de procesos más intensos de individualización, secularización y desorganización de la cultura, sino también de la subordinación de las diferencias étnicas y raciales a las diferencias de clase. Como escribe Redfield, para el meridiano: "la diferencia entre indio y no indio no tiene para él ninguna importancia", "las diferencias étnicas están subordinadas a las diferencias de clase" (Redfield 1944:109). ${ }^{81}$ Se trata de una tesis sumamente optimista, que puede entenderse en el contexto del proceso de modernización y de movilidad social ascendente en la ciudad. No obstante, diversos estudios han documentado cómo las clasificaciones étnicas persisten en Mérida, articuladas también con clasificaciones de clase, tal como se puede advertir en los discursos y prácticas racistas de las elites de Mérida hacia la población indígena del estado (ver Iturriaga 2011).

Procesos muy semejantes los encontramos no sólo en otras comunidades de la zona henequenera, sino también en el sur del estado. Por ejemplo, en su investigación de carácter aplicado llevada a cabo en la comunidad henequenera de Sudzal, Guillermo Bonfil (2005) identificó como los dos grupos fundamentales de la comunidad a los ejidatarios y los no ejidatarios, quienes controlaban el comercio local, la ganadería, la apicultura y algunos servicios públicos. Lo que interesa destacar es que la división entre

\footnotetext{
79 "En todo Yucatán se tiene el mismo concepto de raza y clase dentro de sus contornos más amplios. Dondequiera se reconoce que hay un grupo urbano socialmente superior o dominante, formado por gentes que tienden a ser de color claro, asociado con el idioma español y los apellidos españoles, y un grupo rural socialmente inferior, subordinado o periférico, formado por gentes de piel obscura y asociado con el idioma maya y los apellidos mayas. En todas partes se reconoce que estos grupos no se distinguen con absoluta precisión y que hay individuos intermedios" (Redfield 1944:104).

${ }^{80}$ Por ejemplo, en Tusik, el apellido tiene poca importancia como signo de diferenciación, mientras que en Dzitás era de suma importancia.

${ }^{81}$ Desde luego, esta aseveración resulta por lo demás cuestionable, como ha mostrado Iturriaga (2011) en su estudio sobre el racismo de las elites meridianas.
} 
ejidatarios y no ejidatarios era considerada de mayor importancia que la de "mestizo""gente de vestido" (Bonfil 2005:183-185). A pesar de que Bonfil tenía un marco teórico distinto al de Redfield, mucho más cercano al marxismo y crítico de la antropología cultural norteamericana, llegaron a conclusiones similares: "el 'mestizo' y el macehual están dejando de ser, para dar lugar al campesino-ejidatario henequenero, cuyas características esenciales no son ya ni el vestido ni el origen de su apellido, sino la posición económica que guardan dentro de la estructura económica, es decir, su condición de usufructuarios de la tierra" (Bonfil 2005:193).

El "cambio étnico" que devino gracias a los procesos de modernización de la Revolución fue registrado con detalle por el antropólogo Richard Thompson en la ciudad de Ticul $^{82}$ hacia finales de la década de los sesenta del siglo XX. Fue especialmente el desarrollo de la industria artesanal, junto con el del sistema de educación pública, el que tuvo un importante impacto en las formas de identificación de los habitantes de Ticul. Los mestizos, identificados con lo indígena, ${ }^{83}$ comenzaron a convertirse en catrines, categoría que remite a lo hispano. ${ }^{84}$

Gracias a la industria artesanal del calzado, muchos de los hijos de los mestizos campesinos pudieron convertirse en obreros y formar parte de la sociedad urbana, dejando atrás sus tradiciones agrícolas. Sobre todo, dicha industria contribuyó de manera fundamental a la desestabilización de la dicotomía clásica entre el campesino de habla maya y el pueblerino de habla hispana, a tal grado que, para Thompson, "la vieja

\footnotetext{
${ }^{82}$ Ticul es un pueblo antiguo ubicado en la Región Puuc, en el corazón del que fue reino de los Xiu en tiempos de la Conquista (Thompson 1974:17). Para el momento en el que Thompson llevó a cabo su investigación, la ciudad de Ticul, contaba con 13 mil habitantes, era un importante centro comercial y de pequeñas industrias, destacando la del zapato, pero también de agricultores y artesanos. A nivel municipal, la fuerza laboral estaba constituida de la siguiente manera: 2770 personas en la agricultura, 1361 en la industria y 729 en negocios y servicios. En cuanto a la ciudad de Ticul, la fuerza laboral urbana estaba compuesta por 4212 individuos (1361 en industrias caseras, 729 a negocios y servicios) (Thompson 1974:71)

${ }^{83}$ La categoría de mestizo en Ticul remite a lo indígena, pero no a la categoría maya tal como la trabajé en el capítulo anterior. El propio Thompson anota que a los mestizos no se les reconoce como "los representantes impolutos de varios milenios de cultura maya" (Thompson 1974:28), sino se les asocia sobre todo al uso del traje tradicional (el huipil y las alpargatas), a la práctica de la milpa, los que hablan la lengua maya (Thompson 1974:25-28). Por su parte, Hervik (1999) observó que la mayoría de los así llamados "mayas" del sur de Yucatán se llaman a sí mismos como mestizos, y que "Los mayas laicos contemporáneos en Oxkutzcab no se asocian a sí mismos como descendientes de los constructores de las pirámides, templos y juegos de pelota" (Hervik 1999:94)

${ }^{84}$ Thompson nos ofrece los siguientes datos: "Excluyendo a 9 individuos ( 3 en la industria del calzado) hijos de padre catrín, cerca del 40\% de los zapateros (8 de 19) han pasado de mestizos a catrines y sólo la quinta parte de los restantes (21 de 95) han efectuado el cambio étnico" (Thompson 1974:84).
} 
distinción racial entre el indio y el no-indio [si bien no ha desaparecido...] su significado se va perdiendo y modificando con el paso del tiempo" (Thompson 1974:24). Ahora, un individuo podía pasar por su propia voluntad de una categoría a otra, reemplazando su ropa tradicional por una de tipo europeo, cambiando de ocupación y, especialmente, hablando español en vez del maya. "Hablar bien el castellano —observa Thompson (1974:112) — es el requisito más importante para el cambio étnico". La frontera étnica entre mestizos y catrines se convirtió en "una membrana extremadamente permeable; gran número de mestizos la atraviesan con relativa facilidad el cambiar de identidad étnica" (Thompson 1974:122-123). Así, la industrialización y la educación pública proporcionaron recursos para el cambio étnico, el cual, a su vez, redituaba en mayor capital económico y simbólico, ya que el sector profesional era el más prestigioso, mientras que la milpa era considerada la actividad más humillante. Sin embargo, las distinciones de tipo étnico seguían pesando, ya que, según Thompson (1972:121), "con frecuencia es más importante para la gente de cualquier nivel socioeconómico que una persona determinada sea catrín o mestizo que el que sea zapatero o sombrerero, rico o pobre, joven o viejo". Pero al igual que Redfield, para Thompson era evidente que los mestizos dejarían de ser tales (de ser indios), para ser como los españoles: "los mayas de ayer, con la cultura que conservan los mestizos de hoy, serán los vecinos hispánicos de mañana, la culminación de cuatrocientos años de aculturación” (Thompson 1974:190).

\section{La celebración de lo maya, el sometimiento de lo mestizo}

En ninguna de las comunidades revisadas parece existir una conciencia étnica que abarcara a todos los hablantes de la lengua maya. No obstante, desde inicios del siglo XX encontramos diversos proyectos de "revitalización" de los mayas. Acaso el primero de ellos sea el del gobernador Salvador Alvarado, quien introdujo la Revolución a Yucatán en 1915 (Joseph 1992). Como ha observado Beatriz Urías (2008:188-189), el programa de "revitalización del espíritu de "la raza" maya de Alvarado tuvo tres iniciativas concretas: la fallida "Ciudad Escolar de los Mayas", el financiamiento de una arquitectura oficial al "estilo maya" y la propaganda de la revolución constitucionalista empleando la lengua maya. Mientras Alvarado celebraba lo maya, se propuso convertir a los peones esclavizados de las haciendas en un proletariado rural moderno. Para ello 
abrió nuevas posibilidades de organización a campesinos y trabajadores asalariados, tanto urbanos como rurales, dando lugar a las corporativistas "Ligas de Resistencia". Pero como ha advertido Gabbert (2004:94), Alvarado consideró la cultura de los maya hablantes de clases bajas como un signo de retraso. Así, uno de sus agentes de propaganda describía una ceremonia de cha'chaak como una farsa, como la celebración de unos pobres, ignorantes y supersticiosos. Los mestizos yucatecos le parecían "criaturas sin ambición, desinteresadas en la vida civilizada" (Gabbert 2004:95). En la visión de Alvarado encontramos viejas imágenes sobre los indios de Yucatán, como que éstos son una raza degenerada y viciosa, por lo que, el 8 de febrero de 1918, publicó un decreto para prohibir el consumo de alcohol en el estado.

Fue especialmente el gobernador Felipe Carrillo Puerto quien celebró de manera enfática lo maya. A partir del estudio de Urías (2008), podemos argumentar que en Carrillo Puerto encontramos una disociación entre lo maya y lo mestizo: mientras que la primera entidad era celebrada, la segunda era sometida a diversas formas de biopoder.

Urías (2008) ha mostrado que el discurso socialista de Carrillo Puerto estuvo constituido de importantes elementos teosóficos. Así, un símbolo frecuente en los discursos del gobernador yucateco, el de la "raza roja", no sólo aludía al discurso socialista, sino también a "doctrinas espiritualistas que recreaban el mito de una raza que fue la primera [en] poblar el planeta" (Urías 2008:202). En un tono semejante, las monumentales pirámides mayas eran asociadas a los triángulos teosóficos, símbolos del equilibrio universal. No es casual que uno de los actos más célebres del proyecto mayanista de Carrillo Puerto haya sido la inauguración de la carretera que conduce a Chichén Itzá en julio de 1923. En esta ceremonia, Carrillo Puerto proclamó un memorable discurso en lengua maya desde la cima de la pirámide de Kukuklán, un centro simbólico del poder. A partir de Geertz (1994), podemos argumentar que parte del "carisma" de Carrillo Puerto irradiaba de esos centros activos del poder que son las zonas arqueológicas, consideradas por él "santuarios que albergaban un espíritu superior" (Urías 2008:193).

Si bien Carrillo Puerto suscribió la tesis de la continuidad entre los antiguos mayas y los indios contemporáneos al constatar la herencia cultural de la raza maya, la cual buscaba revitalizar, también identificó una "herencia negativa" y se propuso la 
"regeneración física, mental y espiritual de la raza maya" (Urías 2008:193-194). Es decir, se propuso someter a los indios contemporáneos a diversas formas de biopoder a través de políticas eugenésicas. Por ejemplo, llevó a cabo programas de control de la natalidad, celebró las "Semanas de salubridad" y los "Concursos del niño sano", amén de las cruzadas antivenéreas destinadas a erradicar la sífilis (Urías 2008:195-196). La revitalización del espíritu maya y la biopolítica de "higiene y mejoramiento de la especie" iban de la mano y se sustentaban en la disociación categórica entre mayas y mestizos. ${ }^{85}$ El siguiente pasaje de uno de los discursos de Carrillo Puerto ilustra muy bien lo anterior:

"Yucatán es maya"... nuestro pueblo ha sido esclavo por cuatro siglos, conquistados físicamente pero nuestra vida cultural persistió, retuvimos nuestro bello lenguaje, nuestras costumbres, modos de habitar, religión, vestido, comida, también nuestras canciones, danzas, relaciones sociales; los españoles en Yucatán han absorbido muchos de nuestros hábitos y vida y son más como Mayas que como españoles; la revolución en Yucatán tiene un objetivo principal: darle a los mayas su estatus como hombres libres; tendremos un Yucatán que preserve todo lo que es rico, bello y útil en las tradiciones de los mayas y al mismo tiempo un Yucatán que absorberá todo lo que puede ser usado de lo nuevo y lo moderno en la ciencia (citado en Gabbert 2004: 97).

Hay que advertir que el discurso mayanista de Carrillo Puerto se subordinaba a su discurso socialista y teosófico. El desarrollo y fortalecimiento de la conciencia étnica de los campesinos y trabajadores asalariados debía conducir al fortalecimiento de la conciencia de clase (Fallaw 2008:562). Pero resulta llamativo que, como ha apuntado el historiador Ben Fallaw (1997), ni el discurso mayanista de Carrillo Puerto, ni el de Lázaro Cárdenas durante su visita en Yucatán, lograra desarrollar en su momento una conciencia étnica maya entre los maya hablantes del estado.

En este orden de ideas, podemos detenernos en un caso de movilidad social de un personaje indígena que ilustra la complejidad de las categorías étnicas en Yucatán: Bartolomé García Correa, la primera persona de ascendencia maya que gobernó el estado (1930-1934). García Correa nació en Umán, en el seno de una familia maya-hablante. No

\footnotetext{
${ }^{85}$ Del mismo modo, el partido socialista de Carrillo Puerto rechazó la continuación del sistema de cultivo de roza y quema, parte fundamental de la cultura de las comunidades indígenas del estado (Gabbert 2004:96).
} 
obstante su origen rural, pudo posicionarse en la clase media urbana gracias a la ocupación de sus padres, sus apellidos hispánicos, su educación en Mérida y el apoyo de la iglesia y de algunos terratenientes blancos. En este contexto, ¿era indio García Correa? A pesar de su movilidad social ascendente (o más bien, acaso debido a ella), García Correa nunca estuvo libre de ser objeto de discriminación étnica. Muchos se referían a él como "indio", pero rara vez como "maya". De hecho, él mismo nunca se identificó como maya (Fallaw 2008:553-554). ${ }^{86}$

Como sugiere Fallaw, hay que entender a García Correa como un intermediario entre su comunidad y el sistema económico y político nacional. A cada una de las partes le ofrecía distintas concepciones sobre la población indígena de Yucatán. Al mismo tiempo, él era considerado de forma distinta por cada una de las partes que mediaba: mientras que para el ámbito local (especialmente para sus enemigos políticos) García Correa era considerado "indio", para los del centro del país era más bien mestizo (en el sentido común de la palabra, no mestizo yucateco). Su condición étnica no estaba fija, dependía tanto del observador como del contexto (Fallaw 2008:566).

En el marco de sus relaciones de intermediación, García Correa promocionó una interesante performance, el poema dramático Payambé, escrito por Luis Rosado Vega, estrenado como ópera en Mérida en 1928 y en el Teatro Abreu de la ciudad de México en 1929. Payambé está inspirada en la antigua cultura maya, se trata de una "evocación de la tierra del Mayab", y en su puesta en escena exhibe imágenes del glorioso y exótico pasado maya, destinado especialmente para el consumo de los políticos de la capital del país (Fallaw 2008:568). Era una performance de la categoría maya. En contraste, a lo mestizo había que integrarlo a la sociedad nacional. Como observa Fallaw (2008:566), García Correa dedicó especial atención a la "castellanización” de los mestizos yucatecos, ya que, para él, continuar hablando la lengua maya perpetuaba "una ideología de servidumbre y esclavitud", y aprender el español llevaría a "destruir el pesimismo moral e intelectual de "el indio"”. Había que convertir a los indígenas de Yucatán en mestizos

\footnotetext{
${ }^{86}$ Por su color de piel oscura y su manera de caminar, García Correa fue apodado "Box Pato" (Fallaw 2008:557).
} 
mexicanos en el nombre de la revolución. ${ }^{87}$ Por esos mismos años, el intelectual yucateco Oswaldo Baqueiro Anduze (1937) escribía, en una línea muy similar a la de Lévy-Bruhl, que la lengua maya reproducía un pensamiento prelógico y supersticioso entre los indígenas. En este punto nos encontramos de nuevo con una disociación de categorías: por un lado, la categoría maya, objeto de orgullo y reivindicación; por otro, la de mestizo, a la que hay que someter a políticas de integración.

Recapitulando. Los procesos étnicos en Yucatán, tanto los de etnogénesis (en el oriente del estado) como de desindianización (notablemente en la zona noroccidental de la entidad) no pueden entenderse como un simple proceso de aculturación a la manera de un continuum folk-urbano, sino en el marco de procesos regionales económicos y políticos, como la guerra de castas y el desarrollo de la industria del henequén. Hemos visto que no existen dos grupos étnicos claramente delimitados, pero sí un sistema de categorías étnicas que varía regionalmente. Por último, me he detenido en un caso que ilustra un proceso de movilidad social ascendente y que ilustra algunas de las complejidades del sistema de categorías étnicas de Yucatán: García Correa, el primer gobernador del estado de ascendencia maya, no era fácil de clasificar como indio o no indio. Su clasificación dependía tanto del contexto como del observador. Asimismo, García Correa ilustra bien la disociación entre las categorías mayas y mestizos: la primera se celebraba en performances como Payambé, la segunda se sometía a políticas de integración. Por último, subrayo que García Correa nunca se identificó como maya, no obstante que reivindicara dicha entidad. En el siguiente apartado expondré diversos actores que, a partir del control de recursos significativos y el cuestionamiento y apropiación de órdenes clasificatorios étnicos, sí se identifican como mayas. Es decir, analizaré el proceso de mayanización de los mestizos yucatecos.

\section{La mayanización de los mestizos yucatecos}

Me centraré específicamente en un conjunto de actores individuales y colectivos que, en las últimas décadas, han logrado controlar una serie de recursos significativos y cuestionar los órdenes clasificatorios simbólicos hegemónicos en torno al fenómeno

\footnotetext{
${ }^{87}$ Desde luego, la visión de García Correa sobre los mayas antiguos no era la única. Intelectuales como Antonio Mediz Bolio y José Castillo Torre lo criticaron fuertemente al mismo tiempo que se reconocían como los verdaderos conocedores de los mayas (Fallaw 2008:568-570).
} 
étnico en Yucatán: intelectuales y escritores mayas, las dos organizaciones mayas que han tenido mayor presencia en el estado durante los últimos veinte años, Alianza Maya y Maya'on, y terminaré ilustrando los procesos descritos a partir de la historia de vida de uno de los actores más visibles que reivindican al Pueblo Maya en Yucatán.

En términos generales, estos actores mayas comparten diversas características: durante su infancia $\mathrm{y}$, en algunos casos, su adolescencia, vivieron una suerte de vergüenza étnica, ante la cual intentaron negar los elementos diacríticos que los identificaban como indígenas (la lengua, el vestido, ciertas costumbres, etc.). Vivieron también procesos de movilidad social ascendente, especialmente a través de la educación, a partir de la cual han obtenido recursos como hablar por lo menos dos lenguas (el español y la maya), un conocimiento de la historia nacional y de la población maya, una red de relaciones sociales, así como una reivindicación de su condición étnica. Todo esto ha sucedido en un contexto en el que comienza a reconocerse (aunque sea a niveles discursivos) el valor de la diferencia cultural y, particularmente, de las culturas indígenas. De esta forma, los elementos culturales y recursos controlados por estos actores mayas comienzan a ser significativos para quienes no se reconocen como mayas. Es decir, se convierten en fuentes de poder. Primero revisaré brevemente estos cambios en la posición del Estado con respecto a las culturas indígenas. Luego pasaré a describir de manera sucinta cada uno de los actores mayas referidos.

\section{Transformaciones de la política indigenista}

En términos estrictos, la política indigenista en México surgió en el siglo XX, en el marco del movimiento revolucionario de inicios de siglo. Si bien las reflexiones de los no indios sobre los indios son muy anteriores al siglo XX (Villoro 1979), el ideal de integración de la población indígena a la nación mexicana es un postulado esencialmente revolucionario. A diferencia de momentos anteriores, la política indigenista del siglo XX no tenía fines segregacionistas, asimilacionistas o incorporacionistas. Es decir, no buscaba mantener a los indios en espacios separados a los de los no indios. Tampoco

pretendía borrar toda diferencia cultural. Se trataba sobre todo que los indios se sintieran mexicanos. Si bien éstos podían conservar algunos elementos de su cultura (formas artísticas, su lengua, etc.), resultaba necesario que superaran el sentimiento etnocéntrico 
de identificación con su comunidad local y que pasaran de una condición de casta a una de clase. ${ }^{88}$

No me detendré más en la teoría e ideología del indigenismo, pues ha sido ampliamente abordada por diversos estudios. Me interesa destacar que, como han mostrado distintas investigaciones, la praxis indigenista no siempre coincidía con la teoría indigenista ${ }^{89}$ Del mismo modo, cabe subrayar las consecuencias inadvertidas de la acción indigenista, que en ocasiones tuvieron efectos contrarios a lo que la teoría indigenista promulgaba. Por ejemplo, a través de la formación de los Promotores Culturales, los agentes por excelencia de la aculturación inducida, surgieron intermediarios que fungieron como líderes de organizaciones étnicas (Vázquez 2010).

Con todo, a partir de la década de los setenta, la política indigenista atravesó por importantes transformaciones. Una de ellas fue que la valoración positiva por las culturas indígenas se hizo mucho más explícita, en un contexto de "búsqueda gubernamental de nuevas formas de legitimidad y control político" (De la Peña 1995:123), tras las movilizaciones de 1968, así como las críticas a las políticas indigenistas por parte de los científicos sociales (González Casanova 1965; Warman et al. 1970). Al respecto, la Declaración de Barbados firmada en 1971 por un grupo de antropólogos latinoamericanos (entre ellos Guillermo Bonfil y Darcy Ribeiro) fue un importante evento en la reivindicación de los "grupos étnicos". En ese mismo año, una nueva Ley de Reforma Agraria en México tuvo un importante impacto en la movilización de comunidades indias para la recuperación de sus tierras. Por ejemplo, sentó las condiciones para el proceso de purepechización de los tarascos de la sierra de Michoacán (Vázquez 1992). Es en este contexto que el Estado mexicano promovió la conformación de diversas organizaciones que reivindicaban las culturas indígenas del país, como la Organización de Profesionistas Indígenas Nahuas, A.C. y el Consejo Nacional de los Pueblos Indígenas, ambas conformadas en 1975 (ver Sarmiento 1985). Una de las organizaciones más notables, la Alianza Nacional de Profesionales Indígenas Bilingües (ANPIBAC), surgió en 1977, y ha impulsado la idea de reforzar y utilizar la "conciencia étnica" como base para la movilización política, al mismo tiempo que ha estado

\footnotetext{
${ }^{88}$ Véase Gamio (1982), Aguirre Beltrán (1991).

${ }^{89}$ Ver, por ejemplo, Sariego (2002). Para el caso de Yucatán, puede verse el estudio de Iturriaga (2004) sobre el Centro Coordinador Indigenista de Peto.
} 
estrechamente relacionada con el PRI. ${ }^{90}$ Otro ejemplo, ilustrativo para lo que expondré más adelante, es la constitución de la Asociación de Escritores en Lenguas Indígenas, A.C. (AELI) en 1993 (Gutiérrez Chong 2001:161-162. 164, 166). En el marco de todos estos procesos surgieron nuevos intermediarios que, como ha observado Guillermo de la Peña (1995:118), “construyen su 'indianidad' como un elemento de resistencia, en contraste con los intermediarios anteriores, que habían aceptado los valores del discurso indigenista".

Asimismo, a partir de la década de los setenta se establecieron instituciones académicas que daban especial acogida a la población indígena. En 1977 se abrió el grado en Ciencias Sociales en el Centro de Investigaciones e Integración Social (CIIAS), en Oaxaca, lo que, de acuerdo con Gutiérrez Chong, inició una nueva fase en la capacitación profesional para indígenas. En 1979 el Centro de Investigaciones Superiores del Instituto Nacional de Antropología e Historia (CISINAH, hoy CIESAS) abrió el Programa de Formación Profesional de Etnolingüistas. En 1982 la Universidad Pedagógica Nacional abrió la licenciatura en educación indígena y, en 1990 el CIESAS, el INI y la Dirección General de Educación Indígena (DGEI) abrieron la maestría en lingüística indoamericana.

A nivel regional y estatal, hay que destacar que en Yucatán fueron el INI y la SEP las que, en 1964, comenzaron a promover la lecto-escritura en lengua maya, y que en 1979 se puso en marcha de manera oficial la Educación Bilingüe-Bicultural. En 1980 se estableció la Unidad Regional de Culturas Populares de Yucatán (URCPY), en donde, dos años después, el reconocido escritor Carlos Montemayor (1947-2010) coordinó el Programa de Lengua y Literatura Maya. A partir de 1982, la URCPY ha colaborado con el INI para organizar los Encuentros de Cultura Maya. ${ }^{91} \mathrm{Y}$ en ese mismo año se fundó la radio emisora del INI XEPET "La voz de los mayas". Todas estas instituciones han sido clave en la emergencia de una identidad étnica maya entre una serie de actores, como intelectuales, profesionistas, escritores, organizaciones indígenas. Del mismo modo,

\footnotetext{
${ }^{90}$ La ANPIBAC cuenta con una sede en Yucatán, bajo el mando del etnolingüista maya e inspector de educación indígena en la región maya de Yucatán Bartolomé Alonzo Caamal (Gutiérrez Chong 2001:57).

${ }^{91}$ El Programa de Lengua y Literatura Maya también ha llevado a cabo talleres en algunas comunidades, impulsando la capacitación de los niños a través de los albergues del INI, así como la organización de recitales literarios-musicales, encuentros regionales de escritores mayas, y ha editado la colección Letras mayas contemporáneas, cuya primera serie apareció entre 1990 y 1992 (Leirana 2001:114).
} 
como ha observado Ella Fanny Quintal (2005), la estación de radio XEPET ha tenido impacto en la identidad étnica en el sur del estado.

En 1988 se conformó el Consejo Supremo Maya como una organización intermediaria entre el gobierno del estado y las comunidades mayas. Este Consejo, de carácter semioficial y estrechamente vinculado con el PRI en Yucatán, fue suprimido en el 2001 tras el establecimiento del PAN en el gobierno estatal. En diciembre de 2000, hacia finales del gobierno de Víctor Cervera Pacheco (1995-2001), se creó el Instituto para el Desarrollo de la Cultura Maya del Estado de Yucatán, encargada de los "asuntos mayas", los cuales trata, principalmente, en términos culturales (Castillo Cocom 2005:25; Leirana 2001:83-85; Mattiace 2009:37-39)

En relación con estos procesos se ha conformado un sector de intelectuales, intelligentsia, profesionistas y organizaciones indígenas, conscientes de su cultura étnica (Gutiérrez Chong 2001:159). En estos actores podemos apreciar, de acuerdo con Gutiérrez Chong, tres preocupaciones generales: una tendencia discursiva a elogiar el pasado, una protesta para denunciar las condiciones de marginalidad étnica, y la conciencia de la necesidad de que los indios se ocupen de sus asuntos y destino (Gutiérrez Chong 2001:157). ${ }^{92}$

\section{Los escritores mayas}

Entre los intelectuales indígenas de Yucatán, los escritores que se identifican como mayas han conformado todo un "movimiento literario maya" que ha jugado un papel notable en la reivindicación del Pueblo Maya (Leirana 2001). La lingüista y antropóloga Cristina Leirana ha estudiado dicho movimiento, proponiendo que, en términos de Bonfil, se trata de un movimiento tanto de resistencia como de apropiación. ${ }^{93}$ Es decir, los escritores mayas controlan y ejercen decisiones no sólo sobre sus elementos culturales

\footnotetext{
${ }^{92}$ Un punto crítico es que estos intelectuales y profesionistas no sólo han logrado ascender socialmente, sino que también han manifestado cierta insatisfacción con diversas áreas del proyecto nacional (Gutiérrez Chong 2001:56).

${ }^{93}$ La hipótesis de Leirana es que "El movimiento literario maya contemporáneo puede entenderse como de resistencia; se encuentra enmarcado en un lento avance de manifestaciones más claras de la pluriculturalidad en el país (de la cual da cuenta la presencia reducida, pero creciente de la lengua maya en los medios de comunicación social). Los autores mayas han llegado por diversas vías a la creación literaria, pero todas están relacionadas con la impugnación o resistencia a las políticas culturales/indigenistas/lingüísticas, instrumentadas al margen de su participación” (Leirana 2001:15).
} 
propios (como la lengua maya y una serie de valores de sus comunidades de origen), sino también de la escritura latina, así como de redes de relaciones con las instituciones a nivel nacional.

En términos generales, los escritores mayas son individuos que nacieron en comunidades rurales y que lograron cierta movilidad social ascendente e integración a la cultura dominante. Pero, como argumenta Leirana (2001), dichos individuos fueron y siguen siendo víctimas de la discriminación por parte de los segmentos desindianizados de la sociedad, lo que ha contribuido a aclarar la conciencia de este sector con respecto a sus diferencias culturales. Es por ello, nos dice Leirana (2001), que "retornaron" a la cultura maya.

Algunos de los más reconocidos escritores mayas (como María Luisa Góngora Pacheco, Miguel May May, Santiago Domínguez Aké, Gerardo Can Pat y Feliciano Sánchez Chan) se formaron en el antes citado Programa de Lengua y Literatura Maya de la URCPY. Entre ellos, Feliciano Sánchez, galardonado tres veces con el Premio Estatal Itzamná de Literatura en Lengua Maya, ha participado activamente en la demanda por los derechos indígenas. Otro centro de formación de escritores mayas es la Academia de la Lengua Maya de Yucatán A.C., de donde destaca Domingo Dzul Poot, quien ha publicado tres libros bilingües de recopilación de cuentos de tradición oral (Leirana 2001:130). También encontramos diversos escritores que no forman parte de organización alguna. Entre ellos hallamos a Armando Dzul, profesor de una escuela primaria en Maní, y quien organiza y dirige presentaciones teatrales en maya; Patricia Martínez Huchim, que también es profesora de lengua maya; Vicente Canché Canul, entre otros (Leirana 2001:141-142)..$^{94}$

A la par del incremento de escritores mayas en el estado, desde la década de los noventa del siglo XX también han aumentado los eventos, congresos, encuentros y redes de escritores, así como de las publicaciones en maya y bilingües (maya y español) (Leirana 2001:151-152).

Como he planteado anteriormente, por lo general, estos escritores vivieron en su infancia, adolescencia e incluso en los inicios de su vida adulta cierta vergüenza étnica

\footnotetext{
${ }^{94}$ También hay que mencionar, por su presencia a nivel regional, al Taller Literario Génali, que inició en 1992 en la Casa de la Cultura de Calkiní, en Campeche, y al que pertenecen literario Waldemar Noh Tzec, Briceida Cuevas Cob, Alfredo Cuevas Cob, entre otros escritores.
} 
con respecto a su cultura de origen. Por ejemplo, un escritor relata que, en referencia a la lengua maya:

no sabía porque la hablábamos ni de donde provenía, inclusive reconozco que hubo un tiempo en que pensaba que no era importante, y que hubiera sido mejor que no nos la hubieran enseñado, y que nosotros ya no la enseñáramos, que era más interesante aprender el español (en Leirana 2001:159).

Más de un escritor narra que en la escuela primaria aprendió que la lengua maya no tenía ningún valor y que, por lo tanto, debía hablar el español. ${ }^{95}$ Pero a través de su formación en los talleres mencionados, amén de otras instituciones dedicadas a temas de cultura indígena y popular, comenzaron a darse cuenta del valor de su cultura propia. Es así que la mayoría de estos escritores se plantean como objetivo la revaloración y recuperación de la cultura maya, de sus diversas costumbres, prácticas y tradiciones. Con todo, hay que señalar que no siempre se trata únicamente de un movimiento "cultural" (Alcalá 2009), sino también de uno más explícitamente político, en tanto los escritores mayas han planteado como una demanda al estado la obligatoriedad de la enseñanza del maya como segunda lengua desde la primaria hasta el bachillerato, e incluso que se cree una licenciatura en enseñanza de lengua maya (Leirana 2001:147).

Uno de los elementos centrales en la reivindicación del Pueblo Maya por parte de estos escritores es el argumento de la revitalización étnica. Como observa Leirana, los escritores mayas plantean que existe una etnia maya, aunque "como resultado de la invasión y el sometimiento, se ocultó, pero nunca dejó de existir" (Leirana 2001:288289). Así, a partir del movimiento literario maya — argumenta Leirana - se están sentando las bases "para el desarrollo de una conciencia étnica a nivel de la población total: escritores, maestros, pedagogos e investigadores mayas se dan a la tarea de difundir entre la gente de las comunidades el sentido de una identidad más amplia que la cimentada en la comunidad de origen" (Leirana 2001:289). ${ }^{96}$ Un elemento constitutivo de

\footnotetext{
${ }^{95}$ Aunque también encontramos casos de escritores que, de acuerdo con Leirana, nunca rengaron de sus orígenes, siempre hablaron la lengua maya en sus comunidades y en otros ámbitos (Leirana 2001:184).

${ }^{96}$ Pero no sólo los escritores mayas se adscriben al argumento de la revitalización étnica, Leirana también se adhiere a él, cuando afirma que "Si el común de los mayas no se denomina a sí mismos de esta forma, es porque la discriminación, a lo largo de la historia, les impuso otros nombres: indio, indígena, mestizo, y les robó su patrimonio histórico: mayas los constructores de Chichén Itzá, de Uxmal, y de los otros sitios arqueológicos que nos enorgullecen, y que asombran al turismo internacional” (Leriana 2001:289). Así, los
} 
esta conciencia es la idea de que la cosmovisión maya es una radicalmente opuesta a la occidental hegemónica. Veamos a manera de ejemplo dos reconocidos trabajos de dos distinguidos escritores mayas. Un cuento de María Luisa Góngora Pacheco (originaria de Oxkutzcab, en el sur del estado) y un poema de Feliciano Sánchez Chan.

En su relato "La pobreza"97, María Luisa Góngora narra una historia en donde una anciana llamada Pobreza logra burlar al Señor Muerte al hacerlo subir a un árbol del que era imposible descender. ${ }^{98}$ Cuando después de un tiempo el Señor Muerte logró bajar del árbol, se le había acumulado tanto trabajo que le resultó imposible llevarse a la señora Pobreza. Es por ello que "la Pobreza se quedó en la Tierra. Por eso hasta ahora la tenemos con nosotros".

Algunos estudios de la literatura maya han analizado cómo estas obras ofrecen una visión del mundo distinta a la occidental. Por ejemplo, el filósofo de la ciencia y estudioso del multiculturalismo Raúl Alcalá (2009:323) interpreta el relato de Góngora como una muestra de "una visión diferente a la occidental", como una manifestación de la "inconformidad respecto al tipo de vida que han sido obligados los indígenas de nuestro país", refiriéndose particularmente a la denuncia de las condiciones de pobreza de la población indígena. Por otra parte, el propio Carlos Montemayor ha señalado cómo se personifica la muerte en el relato de Góngora, subrayando particularmente cómo la muerte, encarnada en un señor, no se trata de una "entidad maligna ni demoníaca, ni vinculado a entidades malignas". Resalta también su corporeidad: "no hay señal ninguna de que se trate de un ser incorpóreo ni de una 'aparición' amenazante" (Montemayor 2005:583). Encontramos entonces dos visiones distintas sobre la pobreza y sobre la

indígenas de Yucatán son mayas, pero no lo saben. "Los intelectuales mayas de la península han asumido su papel como promotores de la conciencia étnica: buscan hacerla explícita a quienes no la han desarrollado claramente; reivindicar los rasgos diacríticos de su etnicidad, e instrumentar estrategias de acción cultural y política que contirbuyan a elevar la calidad de vida entre los mayas" (Leirana 2001: 289). Leirana es contundente al respecto: "el renacimiento de la cultura maya se abre caminos con la misma tenacidad que le permitió sobrevivir a la persecución cultural y a las políticas asistenciales. Los mayas están tomando la dirigencia de su movimiento, inaugurando así una nueva época en las políticas culturales, y en el desarrollo de las expresiones de su etnicidad" (Leirana 2001:291).

${ }^{97}$ Publicado originalmente en 1993 en la Colección Letras Mayas Contemporáneas, dirigida por Carlos Montemayor. El texto en español lo preparó el novelista yucateco Joaquín Bestard, con la asesoría de la autora y del escritor maya Miguel May May.

${ }^{98}$ Como observa Montemayor (2005:291): "la 'Muerte' detenida en un árbol mediante un engaño se remonta a la antigüedad griega y hebrea; en su versión italiana la historia apareció en 1525 y la versión francesa de 1719 fue la base de las numerosas reelaboraciones posteriores, incluidas las que aquí hemos comentado". Este tema aparece también en la obra de otro escritor maya, Vicente Canché Moo, particularmente en su relato "Cómo una viejecita engañó a la muerte". 
muerte: en la cosmovisión maya, la pobreza no es sólo material, sino también espiritual, del mismo modo que la muerte no es concebida de manera negativa, sino incluso es personificada y encorporizada; en contraste, en la cosmovisión occidental, la pobreza es entendida en términos materiales y la muerte es valorada de manera negativa (Alcalá 2009; Montemayor 2005). ${ }^{99}$

Consideremos ahora uno de los trabajos más famosos de Feliciano Sánchez, su poema "Ukp'éel wayak" [Siete sueños]. En él, el yo lírico se identifica con diversos elementos constitutivos de la cosmovisión maya. Así, al inicio del poema nos dice:

Soy la Ceiba Sagrada [...]

Soy la vértebra que une

Las trece capas del cielo

Y los nueve niveles del inframundo

Una interpretación posible es que el yo lírico se presenta como uno con el cosmos, en este caso, con los elementos que lo constituyen espacialmente. Del mismo modo, se identifica con el poder creador de la palabra y se presenta como un ser elaborado de maíz (ya que, en el Popol Vuh, libro que relata la creación de los mayas, se indica que éstos han sido hechos de maíz):

Soy nacido de tu vientre maíz

Con el que alimentas a mis hijos

A mis hijos

El soplo con que invadiste

Mi nariz

Levantó su vuelo

De colibrí nocturno

El yo lírico también se identifica con la concepción temporal cíclica de la cosmovisión maya:

\footnotetext{
${ }^{99}$ Me parece que estas interpretaciones sucumben en un dualismo reduccionista. Ya que, dentro de la "cosmovisión occidental", también encontramos corrientes filosóficas y de pensamiento (como el cristianismo) que toman en cuenta la pobreza espiritual. A propósito, véase la crítica de Díaz Cruz (2009:91) al perspectivismo de Viveiros de Castro, quien trata a la cosmología occidental "como si fuera una entidad natural, homogénea, con sus contornos precisos, como si nos remitiera a una cosmología occidental incontrovertible".
} 
Así nazco y muero todos los días

Pues me hallo ligado

A tu eterna sombra

Soy de maíz, tu hijo maíz

Maíz es mi carne, maíz eres, Madre

$[\ldots]$

A propósito no me diste edad

Para renacer día a día

Con el Padre Sol

Soy tu espíritu

Soy el espíritu que emana luz

Soy tu espíritu resplandeciente,

Madre

Y en el Sueño Séptimo, "Las otras muertes", podemos apreciar cómo esta visión del mundo ha sido profanada por "otros":

Soy la Ceiba sagrada,

Madre.

Las otras manos

Sembraron en mis entrañas,

Una mujer mala

Que se lleva a los trasnochados

En los dos casos expuestos (pude haber citado otros más), encontramos que, junto con la defensa de la tesis de la continuidad, se plantea también la cosmovisión maya como un elemento identitario que se opone a la cosmovisión occidental.

\section{Las organizaciones mayas}

El estudio del proceso de mayanización quedaría incompleto si no consideramos a las organizaciones en el estado que se identifican como "mayas". Me detendré en las dos que han tenido una mayor presencia en los últimos veinte años en Yucatán: Alianza Maya y Maya'on. 
Alianza Maya fue la organización étnica más conocida en Yucatán durante la década de los noventa (Suzuki 2006:211-212). Fue fundada en 1993 por Gaspar Antonio Xiu Chacón, quien también fue su presidente. Por debajo de él se encontraban trece coordinadores generales, que funcionaban a nivel regional en el estado. De acuerdo con el propio Xiu, la organización contaba con unas 150 ó 200 mil personas hacia finales de los noventa (Suzuki 2006:215; Castillo Cocom 2005).

Uno de los objetivos principales de Alianza Maya era el de "unir a los mayas de Yucatán en una sola fuerza para luchar por alcanzar su libertad social, cultural, agraria, económica y jurídica" (Alianza Maya en Suzuki 2006:216). En realidad, y como veremos más adelante, la organización jugó básicamente un papel de intermediación entre las comunidades indígenas y las agencias estatales para dirigir recursos estatales hacia los mayas (Castillo Cocom 2005:140).

¿Qué recursos controlaba Alianza Maya? Por un lado, la organización, o al menos su líder, suscribía la tesis de la continuidad entre los mayas antiguos y los contemporáneos. Es decir, se proclamaban como los herederos de la civilización maya, se asumían como los descendientes de los antiguos constructores de pirámides. Así, Alianza Maya fue fundada en uno de los "centros activos del poder" (Geertz 1994) de los mayas: la zona arqueológica de Uxmal. Particularmente, su líder, Gaspar Xiu Chacón, se reivindicaba como descendiente del antiguo linaje Xiu, el cual gobernó Uxmal durante el Post-clásico temprano (1000-1250 d.C.). De hecho, es el carácter noble de este linaje el que le servía a Xiu para proclamarse como líder natural de la Alianza (Suzuki 2006:217). Al respecto, Xiu ha publicado diversos trabajos donde no sólo revisa la historia de los mayas, sino que reconstruye su genealogía hasta llegar a Tutul Xiu, un rey legendario que gobernó Uxmal durante el Post-clásico. ${ }^{100}$

Así, a partir del control de recursos simbólicos (el reconocerse como mayas, sobre todo como descendientes de los antiguos mayas) y culturales (como el conocimiento de la historia), Alianza Maya entró en disputa por otros recursos, como el libre acceso a las zonas arqueológicas del estado. En este sentido, una de las actividades performativas

\footnotetext{
${ }^{100}$ En su libro Usos y costumbres de los indios de Yucatán (1986) Xiu reconstruye su genealogía como príncipe maya. Apunta que la heredera de la dinastía Xiu fue su abuela, Doña Felipa Xiu Quijada, Reina de los Xiu, quien tuvo cuatro hijos: Nicomedes, José Agapito (padre de Gaspar Antonio), José María y Guillermo.
} 
fundamentales de Alianza Maya era la celebración de ceremonias religiosas acompañadas de bailes y canciones en las zonas arqueológicas (Suzuki 2006:216-217). Con estos performances, Alianza Maya no sólo expresaba su mayanidad, sino también su disputa por otros recursos.

Pero Alianza Maya también ejercía control sobre relaciones de intermediación. Acaso este era su recurso más valioso en la arena política yucateca de los noventa. La organización estaba estrechamente vinculada con el PRI, y esta relación definió en gran medida sus concepciones y acciones. Así, como observa Suzuki, Alianza Maya empleaba el concepto de "Tierra Maya", la cual incluye a todos los habitantes de la región, es decir, tanto a indígenas como a mestizos. En este concepto, el término "maya" resulta una noción territorial, no cultural ni racial (Suzuki 2006:218). Suzuki interpretó esta concepción como parte de una estrategia corporativista y clientelar muy afín al PRI: era tan amplia que permitía la membrecía no sólo de mayas, sino también de los demás habitantes de la "Tierra Maya". Esta estrategia resultaba particularmente importante en un contexto de crecimiento del bi-partidismo en Yucatán, especialmente del Partido Acción Nacional en las zonas urbanas y sectores de clase media. Con todo, la observación de Suzuki no es del todo exacta, ya que Xiu planteaba una clara división de identidades en Yucatán: los mayas y los dzules. Para Xiu, el PRI representa a los mayas, mientras que el PAN a los dzules (Castillo Cocom 2005:137). Uno podría no ser maya, pero ser prí́sta y pertenecer así a la "Tierra Maya" de Alianza Maya. Del mismo modo, uno podría ser indígena, pero la filiación panista lo podría dejar fuera de la "Tierra maya".

Asimismo, Alianza Maya dependía económica y políticamente del PRI y tenía que negociar sus intereses en el complejo terreno de la política clientelar y corporativista del partido (Castillo Cocom 2005:141). Aún más, como ha observado Juan Castillo Cocom (2005), Alianza Maya, más que representar a los mayas ante el PRI, representaba al PRI ante los mayas (Castillo Cocom 2005:144), y fue un elemento clave para el establecimiento de relaciones clientelares y corporativas en el medio rural e indígena. De hecho, Xiu no dudaba en presumir su relación con el eminente político priísta Víctor Cervera Pacheco (Suzuki 2006:219-220). 
Castillo Cocom ha analizado cómo Gaspar Xiu empleó su identificación como maya para presentarse y "venderse" al PRI; cómo, a partir de la apropiación de un pasado y un linaje, buscó poder individual y prestigio; es decir, cómo empleó su capital simbólico (el prestigio de su linaje noble y su pasado aristocrático) y su capital cultural (el conocimiento sobre la historia, arqueología y cultura maya) al mismo tiempo que el PRI lo empleaba a él para representar sus ideales ante los mayas (Castillo Cocom 2005:135). En efecto, Xiu, originario de Oxcutzcab, ha sido diputado por el PRI en tres ocasiones ${ }^{101}$ y era conocido entre los círculos políticos yucatecos como El Príncipe Xiu (o bien, como expresa Castillo, el PRIncipe Maya), apodo que recibió del gobernador de Yucatán Carlos Loret de Mola (1970-1976). En síntesis, Xiu supo controlar dos recursos significativos: su linaje noble y las relaciones de intermediación.

En 1997 Alianza Maya comenzó el trámite legal para consolidarse como una asociación cívica, con lo que podría tener un mayor apoyo financiero (Suzkui 2006:220221). Sin embargo, tras el triunfo del PAN en el estado (2001), Alianza Maya ha perdido presencia. De acuerdo con Castillo Cocom (2005:147), en el régimen panista, el capital cultural de Xiu ya no es suficiente para acceder al poder. Aún más, Xiu ha perdido su título real de "príncipe": ni los panistas ni los perredistas le reconocen tal estatus.

Por otro lado, la organización Maya’on, A.C. (Somos Mayas, A.C.) se fundó formalmente en Chichimilah en 1990 con dos tipos de integrantes: por un lado, maestros bilingües; por otro, campesinos milperos del sur del estado de Yucatán. En sus inicios contaba con 26 miembros y, hacia 2009, con poco más de 60. Actualmente es la organización maya con mayor presencia y visibilidad en la península.

Maya’on está organizada a partir de Comités Regionales, ubicados en Valladolid, Peto y Mérida en Yucatán; Hopelchén en Campeche y Carrillo Puerto en Quintana Roo (Quintal 2005:356). En este sentido, es una organización descentralizada, pues cada uno de los Comités Regionales tiene vida y dinámicas propias. Cada comité cuenta con un presidente, un secretario y un tesorero; asimismo, hay un Consejo Directivo Peninsular en el que participan todos los presidentes regionales y todos los que antes hayan sido presidentes. Con respecto a este último aspecto organizativo, Quintal observa que "se

101 Fue diputado durante los gobiernos de Carlos Loret de Mola (periodo 1971-3), Víctor Manzanilla Schaffer (1988-90) y Víctor Cervera Pacheco (1998-2001) (Castillo Cocom 2005:141). 
enfatiza aquí la sabiduría de quien ha pasado por el cargo y que por su edad tiene derechos más allá de los que tendría cualquier otro miembro que no ha cumplido con el servicio" (Quintal 2005: 360)

Los principales objetivos de Maya'on son: “a) conocer mejor la cultura, la lengua y los valores propios de los mayas, b) preservar y difundir ese conocimiento, c) luchar contra toda forma de discriminación" (Quintal 2005:357). Además de estos objetivos, se plantean dos metas básicas: “a) contribuir a que el pueblo maya asuma una identidad acorde con su pasado, su cultura y su lengua y b) influir para que la sociedad más amplia reconozca la importancia del respeto a la diversidad cultural” (Quintal 2005:357).

De acuerdo con uno de sus principales líderes, el etnolingüista Bartolomé Alonzo Caamal, Maya'on no es una organización política, sino una cultural. ${ }^{102}$ Asimismo, se trata más de un grupo de opinión que de acción. En este sentido, entre sus principales actividades se encuentran la organización de talleres de estudio de arqueología, historia y cultura maya, para los cuales han contado con la participación de investigadores invitados de instituciones nacionales y extranjeras (Quintal 2005:357); también organizan encuentros $^{103}$ y han participado de manera activa en el proceso de reforma de la constitución del estado en materia de derechos y cultura maya, en donde han demandado principalmente la oficialización de la lengua maya, de la educación intercultural y bilingüe y el libre acceso a las zonas arqueológicas para poder celebrar rituales.

Uno de los principales recursos significativos que controla Maya'on es sus relaciones con las instituciones públicas. Por ejemplo, tienen una buena relación con la SEP, de la cual suelen obtener diversos recursos para sus eventos, como transporte y equipo de sonido. A decir de Alonzo, "nuestro mejor capital es la credibilidad que tenemos, las relaciones con las instituciones". ${ }^{104}$ También guardan buenas relaciones con

\footnotetext{
${ }^{102}$ Los miembros de Maya'on son básicamente los mismos que los miembros mayas de la ANPIBAC. Pero Maya'on se distingue de esta última organización por su carácter cultural y no estar afiliada a ningún partido político.

${ }^{103}$ Entre estos encuentros son notables los Encuentro Lingüístico y Cultural de los Pueblos Mayas, luego rebautizados como Encuentro Lingüístico y Cultural del Pueblo Maya. Se han llevado a cabo en el 2001 en Guatemala, en el Departamento de San José Petén; en 2002 en Valladolid, Yucatán; en 2003 en Belice; en el 2004 en la ciudad de Guatemala; en el 2005 en Felipe Carrillo Puerto, Quintana Roo; en el 2006 fue en la ciudad de Campeche; en el 2007 en Belice; en el 2008 en Santa Eulalia Huehuetenango, Guatemala; en el 2009 en Chiapas; en el 2010 en Valladolidad, Maya’on fue el anfitrión.

${ }^{104}$ Entrevista a B. Alonzo, 26 de agosto de 2009, Mérida, Yuc.
} 
el INDEMAYA, la CDI, la Universidad de Oriente, el Instituto Nacional de Lenguas Indígenas, las cuales suelen brindarles espacios para realizar sus eventos.

Otros recursos importantes que controlan los miembros de Maya'on son el bilingüismo, los conocimientos sobre la historia y cultura maya, sus redes familiares, que le sirven como apoyo para la organización y participación de eventos, así como la legitimidad de no estar afiliada a ningún partido político. Este último es uno de los elementos más señalados por algunos miembros de Maya'on, acaso como una forma de distanciarse de organizaciones afiliadas al PRI, como Alianza Maya.

Uno de los primeros actos performativos que llevaron a cabo los integrantes de Maya'on fue la reivindicación de la figura de Manuel Antonio Ay, uno de los líderes de los rebeldes durante la guerra de castas, en el pueblo de Chichimilah en 1981. Unos años antes, en 1975, el gobernador del estado Carlos Loret de Mola había colocado un busto de Ay en el parque principal del pueblo. El 26 de julio de 1981, Alonzo y otros estudiantes del CISINAH le rindieron homenaje "para la defensa de la identidad maya". A decir de Alonzo, el número central del evento fue la narración en lengua maya hecha por don Daniel Ay Uitsil sobre las causas de aquel levantamiento y de la traición de la que fue objeto el líder por parte del "dsul Antonio Rejón” (Alonzo 1982:70). ${ }^{105}$ Desde entonces, cada 26 de julio se le rinde homenaje a Ay en Chichimilah, el cual es ahora el líder moral del movimiento, mientras que Chichimilah se convirtió en la sede oficial de Maya'on.

Podemos detenernos en este momento en la obra del líder de los maestros bilingües de Maya'on, el etnolingüista Bartolomé Alonzo Caamal. Alonzo nació en Tixmehuac, una pequeña comunidad rural campesina de alrededor de 3 a 4 mil habitantes. Sus padres son monolingües mayas, y Alonzo aprendió la maya como lengua materna. A los 8 años comenzó a asistir a la escuela, donde aprendió el español. Vivió gran parte de su infancia en Quintana Roo, donde finalizó sus estudios de primaria en un

\footnotetext{
${ }^{105}$ Alonzo interpreta este evento como uno de los principales procesos auto-gestivos de la recuperación de la consciencia maya. Este homenaje también se lleva a cabo en Tixcacalcupul (Yucatán) y en Tepich, Quintana Roo (Alonzo 1993:49-50). También reconoce el papel de la educación indígena bilingüe, de los Comités Comunitarios de Planeación del INI, de las actividades de los técnicos de la Dirección General de Culturas Populares, así como del Supremo Consejo Maya, creado en febrero de 1988 e integrado por 13 diputados mayas, aunque no ha logrado consolidar su programa de acción (Alonzo 1993:50).
} 
internado de niños indígenas. ${ }^{106}$

De manera semejante a lo ya mencionado sobre los escritores mayas, Alonzo narra que durante su adolescencia y juventud vivió un "fuerte conflicto de identidad", ya que, por un lado, nació en la lengua y cultura maya pero, por otro, aprendió que el modo de vida más valioso era el de los no indígenas. A los 16 años ingresó como promotor cultural del INI, cuya tarea era alfabetizar y castellanizar. El INI le apoyó para continuar sus estudios de secundaria y comenzar sus estudios en el Instituto Federal de Capacitación del Magisterio en la ciudad de Mérida. Fue durante sus estudios en la Normal que Alonzo considera que descubrió el valor de la historia y decidió dedicarse a su estudio.

En el ciclo escolar 1975-1976 Alonzo se hizo Supervisor escolar, lo que le ha permitido una gran movilidad, participar en congresos, así como involucrarse en movimientos indígenas. En 1979 ingresó al Programa de Formación Profesional de Etnolingüistas del CISINAH, en Pátzcuaro, Michoacán. Fue ahí donde, declara Alonzo, “confirmé mi posición de que sí soy maya, que somos mayas". Fue en este programa donde "muchos comenzamos a tomar conciencia". Y fue justo ahí donde surgió la idea de conformar Maya'on. ${ }^{107}$

El programa del CISINAH tenía un marcado enfoque etnicista, con profesores como Guillermo Bonfil, Luis Reyes García, Ramón Arzápalo, Yolanda Lastra, entre otros. En él, Alonzo presentó la tesis Los mayas en la política, a través de Chichimiláh, Yucatán, en donde declara escribir en su "condición de maya" y para "los intereses del pueblo maya" (Alonzo 1982:8-9). El objetivo de la tesis es mostrar la persistencia de elementos culturales en el ámbito de la política, especialmente del poder informal del $U$ than nukuch mákohob (consejo de ancianos mayas). Pero la monografía va más allá de dicha documentación, ${ }^{108}$ y tiene como un objetivo más amplio el de "escribir nuestra verdadera historia a partir de nuestra propia perspectiva" (Alonzo 1982:19), tarea que,

\footnotetext{
${ }^{106}$ Lo que sigue se basa en dos entrevistas realizadas por quien esto escribe a B. Alonzo, el 25 de julio y el 26 de agosto del 2009, en Mérida, Yucatán.

${ }^{107}$ Alonzo también ha sido miembro de la ya referida ANPIBAC, ha participado en la edición de Mayaón (boletín de cultura maya, 1987) (Gutiérrez Chong 2001:57), así como en la fundación de la Casa de la Cultura Maya (1990), administrada por la Organización de Profesionales Mayas.

${ }^{108}$ Chichimiláh es una población principalmente agrícola, cercana de la ciudad de Valladolid, de la que depende para la mayor parte de los servicios. De acuerdo con Alonzo, "es la población maya de la zona maicera del estado la menos contaminada por la cultura invasora" (Alonzo 1982:38).
} 
considera, es la más urgente del pueblo maya. Así, bajo esta perspectiva, la "Conquista" española se reinterpreta como una "invasión", como un hecho no consumado (Alonzo 1982:100), y la historia resulta una historia de "sangre y fuego" (Alonzo 1982:108).

A diferencia de lo observado por Redfield, Thompson, Bonfil, entre otros, Alonzo plantea que la principal contradicción en Chichimilah es entre los mayas y los no mayas, entre los masehualohob y los dsulohob (Alonzo 1982:42). En el marco de esta contradicción, Alonzo formula la existencia de dos "esquemas conceptuales" (Davidson 1990), de la oposición radical entre dos cosmovisiones: por un lado, la cosmovisión maya, caracterizada por una filosofía cosmogónica, un equilibrio ecológico de profundo respeto a la naturaleza, con una concepción cíclica e infinita del tiempo; por otro, la cosmovisión occidental antropocéntrica y etnocéntrica, con una concepción unilineal del tiempo, de carácter colonialista, que conduce a la autodestrucción (Alonzo 1982:110; 1993:53). Se trata de "filosofías o visiones del mundo radicalmente opuestos" (Alonzo 1982:112).

Para Alonzo, la cosmovisión indígena, así como sus formas de organización, conforman una alternativa civilizatoria: "la concepción cosmogónica del pueblo maya puede ser el fundamento filosófico para estructurar un proyecto de desarrollo del país que asegure la continuidad de la especie humana, por el profundo respeto que tiene a la naturaleza" (Alonzo 1982:111)

Otro elemento importante en la reinterpretación de la historia es la tesis de la continuidad, evidenciada en la ocupación de un territorio. Así, Alonzo postula que "los mayas seguimos ocupando casi todo el territorio que ocupábamos en la Época Clásica [...] es indiscutible que los mayas somos los primeros dueños de este extenso territorio" (Alonzo 1982: 14). Pero es una historia negada por la dominación colonial, aunque nunca cancelada (Alonzo 1993:37). Uno de los propósitos de los estudios debe ser dar a conocer "la historia particular del pueblo maya peninsular, abarcando desde el pasado prehispánico hasta la actualidad, con la finalidad de mostrar su continuidad y tener una visión amplia y coherente de sus luchas de resistencia ante el proceso de dominación colonial. Estos datos servirán, a su vez, para plantear en el último apartado las ideas básicas de un proyecto histórico del pueblo maya" (Alonzo 1993:43). Hay que apropiarse del pasado, reinterpretar la historia y los símbolos dominantes. Ya que, como ha 
mostrado Geertz (1994), no puede haber ejercicio del poder que no esté relacionado con la búsqueda de una hegemonía simbólica.

En este orden de ideas, ante el mito azteca de la fundación de México, Alonzo plantea que se trata de un mito de la sociedad dominante, un mito de los blancos que sólo tiene significado en el centro de México (Gutiérrez Chong 2001:188-189), y, ante el mito del mestizaje en México, argumenta que en realidad se trata de la apropiación del grupo dominante de ciertos elementos de origen indígena: "cuando hay apropiación del conocimiento indígena, se llama 'mestizaje'. En este sentido, se trata de una cuestión de conveniencia cultural que no beneficia a los indios para nada" (Alonzo en Gutiérrez Chong 2001: 200). Del mismo modo, Alonzo considera que poco importa si Benito Juárez, un "héroe" nacional, fue indio o no, ya que "no hizo nada bueno para su propia gente" (Gutiérrez Chong 2001:226).

Podemos hacer ahora una breve comparación de Alianza Maya y de Maya'on. En términos de control de recursos significativos, ambas controlan recursos de conocimiento de la arqueología, historia y la cultura maya. Las dos organizaciones sostienen la tesis de la continuidad: los de Alianza Maya se reconocen como descendientes de los antiguos mayas constructores de pirámides y su líder, Gaspar Xiu, como descendiente del linaje noble Xiu; los de Maya'on también se reconocen como descendientes de los antiguos mayas, pero en su discurso enfatizan más la situación colonial en la que se ubican los mayas, y más que posicionarse en algún linaje noble, toman como principal símbolo a uno de los rebeldes de la guerra de castas, a Manuel Antonio Ay. Así, Alianza Maya se fundó en Uxmal, antigua sede de gobierno de los Xiu, y Maya'on lo hizo en Chichimilá, lugar de origen de Ay.

Pero mientras que Alianza Maya contaba con recursos del PRI, a partir de los cuales pudo entablar relaciones clientelares, Maya'on enfatiza su neutralidad política y basa su legitimidad justo en la no pertenencia a un partido político. No obstante, sostiene buenas relaciones con diversas instituciones gubernamentales.

Ambas organizaciones tienen como objetivo fortalecer la identidad de los mayas, pero Alianza Maya hizo énfasis en el aspecto político, sobre todo, alcanzar la libertad de los mayas, una libertad que se encontraba estrechamente asociada al PRI; en cambio, 
Maya'on se declara como una organización cultural y no política, y no plantea únicamente la libertad de los mayas, sino la constitución de un estado pluriétnico.

Por último, a partir del control de diversos recursos, Alianza Maya y Maya'on realizan diversos tipos de performances. La primera se dedicó especialmente a la celebración de ceremonias en zonas arqueológicas, mientras que la segunda realiza diversos eventos y talleres académicos relacionados con la historia y reivindicación de la lengua maya, y consideran que los performances de Alianza Maya "no son más que maniobras netamente políticas" (Suzuki 2006:222).

Hasta ahora, en este apartado hemos visto una serie de actores clave en el proceso de mayanización de los mestizos yucatecos: los escritores, intelectuales, y las organizaciones mayas. En términos generales, estos actores solían ser identificados bajo la categoría de mestizos, es decir, como individuos pertenecientes a un ámbito rural, campesino, pobre, atrasado, en donde los diacríticos culturales mayas (como la lengua, el vestido, la agricultura, entre otros) eran motivo de vergüenza étnica.

Gracias a la movilidad geográfica y la escuela, estos actores pudieron ascender en la escala social y controlar una serie de elementos culturales y recursos significativos, como hablar por lo menos dos lenguas (maya y español), conocimiento de la historia y cultura maya, relaciones de intermediación, redes de relaciones con otros actores indígenas e instituciones gubernamentales, prestigio, entre otros.

Los escritores, intelectuales y organizaciones mayas han expresado de manera performativa los distintos recursos que controlan. Lo han hecho a través de obras literarias, concursos de canto, celebración de ceremonias consideradas tradicionales, rituales, homenajes a personajes mayas, eventos académicos, entre otros. Para finalizar este capítulo, presentaré un relato autobiográfico del escritor y promotor cultural Feliciano Sánchez, un actor clave en el proceso de reivindicaciones del Pueblo Maya y que, de acuerdo con la literatura antropológica y lo discutido en el capítulo teórico de esta tesis, podría ser considerado un intermediario cultural y político.

La presentación del relato autobiográfico de Sánchez tiene varios objetivos. Uno de ellos es analizar cómo se viven subjetivamente los procesos históricos, sociales y políticos antes descritos en este capítulo. El análisis de los relatos autobiográficos es una manera privilegiada de dilucidar la relación dialéctica entre los fenómenos estructurales y 
la agencia de los actores. Del mismo modo, me interesa destacar cómo a partir de la narración los sujetos otorgan sentido a sus acciones y a las circunstancias que les tocan vivir. Así, las palabras de Sánchez servirán para ilustrar varias de las problemáticas abordadas en esta tesis: el contraste entre la comunidad de origen y la ciudad, entre el pasado y el presente; las limitaciones económicas, educativas y de infraestructura así como las formas de enfrentarla; el conflicto sociolingüístico entre el maya y el castellano; el papel de las instituciones del estado, las políticas indigenistas y los científicos sociales en la emergencia de la etnicidad; el surgimiento de las figuras de intermediarios políticoculturales y algunas de sus contradicciones y limitaciones; $y$, por último, el planteamiento de demandas y de reivindicaciones del Pueblo Maya. Atendamos la narración de Feliciano Sánchez.

En realidad creo que podría decir que mi infancia en Xaya es como que, creo que fue muy afortunado, fue afortunado en el sentido de que... eran todavía los tiempos aquellos en el que literalmente se vivía del campo, literalmente... no conocíamos todavía muchos de los productos llamados chatarra de la actualidad ¿no?, y siempre había a la mano, o a la generosidad de la naturaleza, muchos productos que se podían consumir; además, las familias del pueblo eran todavía muy dados a ese tipo de consumo, a diferencia de los tiempos recientes y en la actualidad, como que vamos todos en pos de lo que nos anuncien y pregonen. Por eso fue una infancia muy afortunada, contra lo que se podría imaginar que de pronto alguien dice que teníamos limitaciones en cuestiones de alimentación, creo que fue la mejor, porque era todo con productos naturales $y$, con decirte que, por ejemplo, recuerdo que en algún momento me mandaban a recoger las calabazas, partirlas, sacarles las pepitas, las semillas, ponerlas a sancochar para criar a los cerdos. Y de pronto, eh, cuando nos topábamos con una calabaza muy bonita, me llenaba yo antes que los cerdos ¿no? [risas], porque la calabaza sancochada era riquísima. Entonces me llenaba antes que los cerdos. Eso sólo con darte una idea de cómo comíamos, y aun andando en el monte uno se encuentra cualquier fruto, raíz, que pudiera ser comestible, ya sea de manera directa o con algún tipo de procesamiento, pero siempre había. Y en la actualidad muchos de esos productos no los volteamos a ver siquiera.

Podemos apreciar cómo el inicio del relato de Sánchez "enmarca" [frame] la historia de su vida en su infancia, es decir, en el pasado — “eran todavía los tiempos aquellos...”-, y en un contexto rural, casi paradisíaco, en donde, como en el jardín del Edén, los 
alimentos están al alcance de la mano, gracias a la "generosidad de la naturaleza". Este entorno pretérito y rural es contrastado por Sánchez con la "actualidad", caracterizada por la venta de productos "chatarra". Asimismo, en contra de posibles caracterizaciones del entorno rural como algo atrasado o "limitado", Sánchez declara que cree que "fue la mejor", porque "era todo con productos naturales", contrastando así, también, el carácter "natural" de los productos consumidos con el más artificial de los actuales. De este modo, apreciamos una primera construcción con un sistema de diferenciaciones, entre el pasado/infancia-actualidad y lo natural/chatarra, en donde los primeros términos de cada oposición son reivindicados.

Entonces quizás las limitaciones que pudiéramos decir, pero que además eran motivo de otro tipo de actividades, por ejemplo, para esta época de frío, era frío de a de veras, no contábamos con sábanas suficientes, con cobijas, entonces nos tapábamos con costales, antes había un tipo de costal que se decía de yute, que eran muchos más suave que este costal donde viene el maíz o el frijol, hechos de fibras de henequén, ¿no?

Eh, una de las ventajas que nos proporcionaba la época de frío como ahora, donde de repente agarra un frío bastante fuerte, era que... por no poder seguir acostado o durmiendo nos levantábamos muy de madrugada, barríamos el patio de la casa toda la hojarasca que se caía y le prendíamos fuego. Con solo empezar a barrer espantábamos el frío, y luego terminábamos brincando en carreras las llamas de la hojarasca quemándose y nosotros jugábamos, nunca nos dábamos cuenta que con eso estábamos ayudando a mamá a limpiar todo el patio de la casa, pero el resultado era ese, el resultado era ese, porque durante la noche lo que se hacía era, eh, mi papá o mis hermanos mayores traían buena leña del monte y se preparaba carbón, carbón durante la noche. Entonces agarrábamos el carbón rojo y lo poníamos debajo de la hamaca para aguantar el frío. Entonces ahí podríamos decir que teníamos limitaciones, pero ese tipo de vida, a final de cuentas, nos ayudó a conocer el clima, a conocer los elementos de la región, a aprender a respetarlos, a convivir con la naturaleza, a aprender todo el ciclo y procesos de producción de la milpa, a conocer de plantas medicinales, a conocer también, digamos, a interpretar el lenguaje de la naturaleza precisamente para fines de saber cuál era el mejor momento para los distintos trabajos de la milpa.

Entonces, ese momento que yo vivía mi infancia era todavía el momento en el que las milpas producían muy bien, que recuerdo incluso que mi papá tenía dos trojes de maíz guardados en casa, y siempre nos entreteníamos ayudándolos en todo el proceso del trabajo de la milpa, de 
cosecha, almacenamiento, y además, bueno, de saber, por ejemplo que, cuando era época de los zapotes, nosotros bajábamos los zapotes ya sazones y los enterrábamos en el maíz, entonces uno, dos días ya estaban bien maduros a punto de ser comidos. Entonces todo ese tipo de lenguaje lo fuimos aprendiendo en esa etapa de la infancia.

En estos pasajes Sánchez expone una serie de problemas y limitaciones de su comunidad de origen, como el frío que se sufre en invierno. Podemos destacar cómo estos hechos son narrados no sólo como limitaciones, sino como impulsos para construir una dinámica familiar y doméstica, como cuando, para enfrentar el frío, se levantaban "muy de madrugada”, barrían el patio de la casa y le prendían fuego a la hojarasca. De ese modo, aunque no se dieran cuenta, ayudaban "a mamá a limpiar todo el patio de la casa”.

La limitación relacionada con el clima no sólo ayudó a generar cierto tipo de dinámica familiar, sino también a conocer y respetar la naturaleza ("el clima", "los elementos de la región, a aprender a respetarlos, a convivir con la naturaleza"). Así, se construye otro elemento fundamental en las reivindicaciones étnicas y del Pueblo Maya: la relación armónica con la naturaleza. Y, más que la convivencia armónica y respetuosa de la naturaleza, a ésta se le atribuye un "lenguaje" el cual puede ser interpretado, por ejemplo, para trabajar la milpa.

Mi pueblo en ese entonces era un pueblo, podría decirse, fantasma, porque era un pueblo grandecito, pero por cada manzana había una o dos casas cuando mucho, entonces prácticamente los habitantes se habían ido más hacia el sur cuando, según me decía mi papá, la época de las langostas en los cuarentas, cincuentas, pues acabó con todos los alimentos de la región, ¿no? Entonces, cuando yo conocí el pueblo era un pueblo literalmente fantasma, éramos pocas las gentes que habíamos quedado y habían por ejemplo unos árboles enormes de bonete, que yo los veía huecos, todo hueco por dentro, y como en algún momento vi a los cerdos comerse el tronco del bonete, un día se me ocurrió hacerle una pregunta, y decirle oye papi, cómo le hicieron los cerdos para treparse hasta muy arriba a comerse la parte masosa del tronco del bonete. Recuerdo que sólo recibí un regaño ese día, muchos años después entendí que no eran los cerdos, sino que eran nuestros parientes que porque se había agotado toda la alimentación, pues recurrían incluso a la parte masosa de este árbol, para complementar la comida. Lo sancochaban para quitarle la resina y lo mezclaban con un poco de maíz que pudieran conseguir para hacerlo todavía un poquito más redituable. Eh, pero, para mí era parte de la visión fantasmagórica que tenía mi 
pueblo, esos enormes árboles de bonete que estaban completamente huecos por dentro, y además de que, digo, por cada manzana había una o dos viviendas cuando mucho, la parte del centro era la que era más habitada, porque creo que como ocurre en todos los pueblos, ¿no?, la parte del centro es donde está la gente con un poquito más de posibilidades. Entonces, en ese ambiente crecí, Mérida para nosotros era en ese entonces algo muy distante, nada más escuchábamos decir "Mérida, Yucatán”, y decíamos... la primera imagen que yo tenía es que creo me voy a morir y no voy a conocer "Mérida, Yucatán”, ¿no? Varios años después entendí también que "Mérida, Yucatán" era lo que mis padres, mis abuelos y mis mayores nombraban como Thó, entonces entendí que lo que tanto se mencionaba era la gran ciudad que estaba donde actualmente está Mérida, Thó.

$\mathrm{Y}$ en ese contexto, de un pueblo que, para salir a su cabecera municipal, había que caminar diecisiete kilómetros entre lodo, piedra, camino de tierra, por eso, a lo mejor, por eso Mérida se hacía como que uh, demasiado lejos, y era un pueblo que en ese entonces, para principios de los sesenta, se empezaba a levantar nuevamente digamos del azote de las langostas, hasta mediados de los cincuentas, porque recuerdo más o menos que en el 65 o 66, era yo pequeño todavía, teníamos sarampión, y se hizo por primera vez, nuevamente, después de varios años de no hacerse la fiesta patronal del pueblo, ese año lo hicieron. Entonces recuerdo que mi abuelita le decía a mi mamá, "muchacha por lo menos búscate unos costales y unos pañales y pónselos a los niños y sácalos para que vean aunque sea la última corrida, la última corrida de toros". Y cubiertos con pañales y con costales, así nos sacaron a ver, recuerdo, la primera fiesta patronal que yo vi del pueblo. Luego, bueno, había también fiestas patronales en los pueblos aledaños, pero lo que hacíamos era irnos el día de la vaquería y siempre había una casa disponible en cualquier pueblo que uno llegara donde lo reciben a uno: convidaban la comida, ahí permanecíamos toda la fiesta hasta que terminaba la fiesta, regresábamos porque todo era abierto, no había ninguna carretera en aquel entonces.

Si anteriormente vimos cómo Sánchez realiza un contraste temporal entre su infancia en el pasado y la actualidad, ahora vemos una diferenciación espacial: tras una plaga de langostas, su pueblo era "literalmente fantasma". Este pueblo fantasmagórico, que con sus árboles de bonete vacíos por dentro y los presuntos cerdos que se comían su relleno bien podría ser sacado de un relato real maravilloso, es comparado con Mérida, la capital de Yucatán ("Mérida, Yucatán", pronunciada con un tono institucionalista), la cual resultaba "algo muy distante". La distancia no era sólo física sino, también, social, ya que 
para salir de Xaya uno tenía que "caminar diecisiete kilómetros entre lodo, piedra, camino de tierra".

También resulta interesante cómo en este pasaje Sánchez relata que Mérida no era otra cosa que lo que sus padres, abuelos y mayores nombraban como Thó, el nombre de esa ciudad en lengua maya. Como hemos visto anteriormente, un elemento importante en las reivindicaciones étnicas es la reivindicación de los nombres en lengua indígena. Así, encontramos un tercer elemento importante en las reivindicaciones del Pueblo Maya: el contraste entre el espacio rural y el espacio urbano, lejano, distante.

Yo digo que mi infancia la empecé a dejar, digamos, como a los 17 años, cuando ya tuve que salirme del pueblo para terminar la primaria, irme a otra comunidad, aunque ya había, ya me había dedicado a trabajar de lleno con mi papá, ¿no?, en el campo. Además de agricultor era apicultor también y siempre lo acompañaba en todas sus actividades. Lo único que no pude, y no entiendo, nunca entendí por qué no pude, aprender, es, porque él era músico, eso nunca lo aprendí. Pero creo que esta fortuna de estar inmerso en un contexto de trabajo de campo, todo eso fue lo más maravillo que me pudo haber sucedido, porque incluso me ayudó a conocer, digamos, aunque no de manera consciente, a conocer bastante sobre la lengua maya, ¿no? Pues no me limitaba solamente al habla común, o sea a todo lo que, a la lengua que todo mundo sabe, que es hablar, comunicarse, tanto con los amigos, con la familia, con la comunidad, sino yo me metía incluso de manera un poco temprana a disfrutar de las canciones que mi papá cantaba en maya, recopilándolas, las canciones que los artistas de mi pueblo inventaban con motivo del carnaval, ¿no? Lo que hacía la gente de mi pueblo era que, cuando llega el tiempo del carnaval, tomaban piezas que en ese momento estaban pegando fuerte en la radio, le quitaban toda la letra y le ponían una nueva letra a la canción con alguna historia, anécdota historia de algún personaje de la comunidad; a final de cuentas era el carnaval, entonces si a alguien le sucedía algo chusco, algo, no sé, que pudiera parecer interesante, contarlo en el carnaval, ahí acomodaban la letra de la canción contando la historia de alguien de la comunidad, con un ritmo de una canción muy pegajosa. Eso yo también lo recopilaba por gusto, no tenía conciencia de que eso fuera algo interesante.

Lo otro que también me sucedió durante la infancia que muchos años después entendí que era algo bueno, era que... no me agradó el tipo de enseñanza que nos daban en la escuela, y entonces desde, más o menos a los 8, 9 años, fue el primer registro que yo recuerdo, que aprovechábamos la ausencia de los maestros de la comunidad, y entonces armábamos nuestro 
grupo de teatro, invitábamos a los mayores de la comunidad que sabían cantar, tocar, bailar, contar cuentos, adivinanzas, que se sabían los juegos tradicionales y armábamos un festival de a veces de uno, dos días, en ausencia de los maestros. Y entonces yo empecé dirigiendo un grupo de teatro a los 9 años y ahí fue mi, digamos, el primer encuentro fortuito que yo tuve con la escritura de la lengua maya. Como nos enseñaban a leer y escribir en español, entonces, hacíamos las improvisaciones de las obras, porque nunca eran obras escritas las que representábamos, hacíamos la improvisación de las obras, y luego yo tomaba mis notas para tratar de recordar cuando lo volviéramos a retomar, no sé, a dos, tres días después, tomaba mis notas en español así como me enseñaron a escribir. Pero de pronto me di cuenta que esas tres líneas que yo escribía como que no bastaba para recordar muy bien qué era lo que habíamos hablado, qué era a lo que habíamos llegado; de manera accidental, esas notas las empecé a hacer en maya, como buenamente pude porque no nos enseñaban a leer en maya, como en pocos lugares se enseña aún ahora. Entonces escribía en maya y me daba cuenta de cuando las volvía a leer tres, cuatro días, una semana después, recordaba perfectamente de qué se trataba. Se me hizo fácil entonces seguir registrando mis notas en maya, y empecé incluso en ese tiempo a bosquejar mis primeros textos en maya. Pero no me daba cuenta de que eso era algo significativo, sino hasta en 1980, cuando a raíz de una convocatoria que se publicó a nivel estado, se buscaban a 35 jóvenes de aquel entonces que hablaran la lengua para formarse como promotores culturales bilingües. Y entonces yo voy, concurso, y me toca ser seleccionado, y me encontré con algunos que ya venían escribiendo algo en lengua propia, en maya. Entonces, fue cuando descubri que eso de escribir maya puede tener un significado totalmente diferente a lo que yo entendia en ese momento. Fue como marcando un tanto mi infancia, y las constantes migraciones hacia el sur para buscar mejores terrenos para trabajar la milpa, en todas las vacaciones acompañaba a mi papá y a mis hermanos, porque íbamos, a la época de empezar la cosecha, tanto de frijoles, de la milpa misma, para después ir trayendo poco a poco la cosecha para hacia el pueblo. Eso fue algo que me marcó bastante en mi edad temprana.

Fui a otra comunidad. Primero me había ido a Tekax, porque en Tekax había..., en mi pueblo no había más que tercer grado, hasta tercer grado llegábamos. Yo repetí tercer grado como tres, cuatro veces, porque no había más grados. Entonces me fui a Tekax a intentar continuar, y al poco tiempo que llegué a Tekax se abrió una escuela albergue en Kinil, que está a 6 kilómetros de mi comunidad. Entonces, como ahí era, primero era más cerca de casa; segundo, allí nos iban a dar de comer, nos daban hospedaje, nos daban, me parece, una bolsita de detergente para lavar nuestra ropa los fines de semana. Entonces era mucho mejor. En Tekax yo había ido y mi papá era quien tenía que costearme todo hasta donde llegara, entonces preferí regresarme a Kinil para 
continuar con mis estudios. De algún modo en Kinil era casi casi como mi pueblo porque casi todos hablábamos en maya, ese es el otro asunto, que yo tenía muy poco contacto con el español, ¿no? Es hasta que me fui a los 19 años a Teabo a hacer la secundaria, donde entonces empiezo a aprender un poco más el español, avanzar un poquito más en el español.

Estos párrafos resultan de particular interés por varias razones. En primer lugar, porque, de acuerdo con Sánchez, el trabajo en el campo con su padre no sólo fue "lo más maravilloso" que le "pudo haber sucedido", sino también porque le "ayudó a conocer", "aunque no de manera conciente", "bastante sobre la lengua maya". Como hemos visto anteriormente, y tal como aprecia Gellner para el caso del nacionalismo, una cuestión es vivir la cultura, sin ser consciente de ella ("no tenía conciencia de que eso fuera algo interesante"), y otra muy distinta es tomar conciencia de ella, hacerla explícita y reivindicarla.

En segundo lugar, Sánchez nos dice también que no sólo aprendió bastante sobre la lengua maya, que no se limitó al "habla común", sino también a otras expresiones culturales, como la recopilación de canciones cantadas en maya, la puesta en escena de obras de teatro y la organización de festivales. Así, Sánchez se convirtió en una especie de promotor cultural no oficial o reconocido por el estado.

En estos párrafos se asoma también el conflicto sociolingüístico entre el maya y el castellano vivido en la escuela primaria, si bien más adelante en el relato Sánchez abundará en él. Por el momento me interesa destacar cómo, a partir de la convocatoria estatal para promotores culturales bilingües, Sánchez "descubrió" que la lengua maya, hablarla y sobre todo escribirla, podía tener un significado distinto al que él le había otorgado anteriormente. Sobre esto me detendré también más adelante.

Por último, en estos pasajes también podemos apreciar el papel de las instituciones del estado en la formación de los intermediarios culturales-políticos. Ante las limitaciones en materia educativa-formal en muchas comunidades, los albergues escolares del estado — como el de Kinil- jugaron un papel fundamental en el desenvolvimiento de los intermediarios. Así, de esta sección de la historia de vida destaco como un elemento central de las reivindicaciones étnicas el paso de la cultura -sobre todo las culturas subordinadas - vivida como algo inconsciente a ser percibida como 
algo valioso, significativo, que puede ser movilizado, y el papel que las instituciones del estado juegan en dicho pasaje.

Dejo a partir de ahí, digamos que asumo por mi cuenta muchas cosas que tienen que ver con mi vida, por eso hablaba de un rompimiento con mi infancia, porque de algún modo, aun a los 16 años, pues seguía en esa vida familiar, seguía aprendiendo de las cosas que mis mayores me enseñaban, eh, digamos que... mis espacios de tomas de decisión propias son las que la familia me permitía. Pero cuando me fui a Teabo a los 19 años, primero a Kinil a los 17 a terminar la primaria y después a los 19 años a Teabo para hacer la secundaria, prácticamente asumí por cuenta propia la vida. Ahí vi otros niveles de limitaciones porque, en el pueblo, digamos, andando en el monte, en el patio de la casa, donde sea, pues siempre hay mucho que comer; pero cuando me voy a Teabo, prácticamente a dedicar de tiempo completo a hacer la secundaria, y después ya no aportaba para la familia..., me quedaba, me sobraba un poco de tiempo en las tardes, entonces comencé a trabajar para apoyarme, a pesar de que había conseguido una beca, empecé a trabajar en las tardes para apoyarme en, con mis gastos. Entonces es cuando como que asumí por cuenta propia la vida, porque ahí sí las limitaciones económicas eran muy marcadas, ¿no? Caminando íbamos del pueblo a Teabo a la escuela, y los fines de semana, cada quince días, regresábamos caminando 21 kilómetros al pueblo, para ver a los familiares. Entonces ahí sí me di cuenta que el dinero siempre hacía falta, estando en el seno familiar nunca lo noté porque no era necesario el dinero. De repente decía mi mamá "se nos terminó el azúcar, agárrate dos kilos de maíz, ve y cámbialos por azúcar", "se nos acabó la sal, cambia tres huevos ve a la tienda y cámbialo por sal". Entonces yo no notaba ahí la importancia del dinero, pero cuando ya estoy en la secundaria, lejos de casa, lejos del patio de la casa y del monte circundante, del pueblo que nos proveía de muchas cosas que comer, entonces ahí sí me di cuenta que el dinero era importante tenerlo, ¿no?, pues tienes sed o consigues agua en cualquier vivienda y ya empezaron a abundar los refrescos y todo eso, se mantiene uno bastante tiempo en la escuela y entonces hay hambre y pues ahí no vamos a encontrar pozole ni nada por el estilo, entonces sí empecé a notar la ausencia del dinero que ya empezaba también a circular bastante fuerte, aun en las comunidades, y entonces me dediqué a trabajar un poquito por las tardes. Por eso hablo de un rompimiento de la infancia que era como algo fantasioso, de que todo lo resuelves en el patio o en el monte incluso, a ir a un contexto un poquito más urbanizado y todo eso, en donde si no tienes moneda circulante de repente no puedes resolver muchas cosas. Entonces hay un rompimiento muy fuerte en mi vida en ese tiempo cuando yo empiezo la secundaria a los 19 años. 
En esta sección observamos un nuevo contraste entre los espacios vividos. La diferenciación más notable es en materia económica. Mientras que en la comunidad de origen se vivía a través del trueque y de la reciprocidad ("se nos terminó el azúcar, agárrate dos kilos de maíz, ve y cámbialos por azúcar”), en los nuevos espacios operaba una economía de intercambio mercantil, en donde el dinero es imprescindible. La comunidad de origen es relatada como un lugar en donde "no era necesario el dinero". En este orden de ideas, mientras que las limitaciones de la comunidad de origen - como el frío o la ausencia de alimentos - pueden gestar dinámicas familiares, domésticas o comunitarias -el trabajo con la familia, el intercambio con los vecinos-, las limitaciones en un ámbito más urbanizado son más difíciles de sortear. La forma de vencer estas limitaciones era a través de un trabajo remunerado, lo que marcó el paso de la infancia a la vida adulta en la historia de Sánchez. Aquí también se observa un caso en el que lo étnico prescinde del dinero y reivindica otras prácticas de intercambio, como el trueque.

El principio, digamos este..., en la primaria, yo creo que debí haber aprendido suficiente del español, aunque no era una lengua necesaria en mi vida, ¿no? Siempre, siempre teníamos ese problema, no lo procesamos en ese momento, pero siempre teníamos ese problema, todos los libros venían en español, y entonces leíamos las lecciones y había necesidad de buscar de alguna manera de cómo entender lo que decían las lecciones. Para fortuna los libros de aquel entonces tenían debajo de cada lección un pequeño vocabulario que nos explicaba ciertas palabras, que quienes los crearon, o sea, quienes crearon los libros consideraban que era importante que conociéramos esas palabras, ¿no? Entonces... pero si había un conflicto bastante fuerte porque en casa y en la comunidad todo era en maya; entras a las cuatro paredes de la escuela y todo era en español, incluso habían algunos maestros que eran muy duros, yo recuerdo que en algún momento me sacó el maestro para recoger piedritas en la calle, ponerlos sobre la tierra caliente, me pidió que me hincara sobre esas piedritas y, como si fuera un Cristo, me puso libros en las manos, en las palmas de las manos extendidas, era un castigo terrible para nosotros, porque nos cachaba hablando maya en el salón de clases. Era prohibidísimo hablar maya en el salón de clases. Entonces, eso me llevó como que a una actitud de odiar el español incluso, llegué a odiar hablar el español porque todo era, todo significaba castigo para mí, el no hacerlo significaba castigo; por el contrario, si hablábamos el maya como era muy común entre nosotros, o sea, si nos 
descubrían hablando maya también significaba castigo; llegué a odiar hablar el español, de modo que yo decía, que yo decía..., que yo negaba que hablaba español.

En este párrafo apreciamos con mayor claridad el problema del conflicto sociolingüístico entre el maya y el castellano. El castellano era la lengua oficial e institucional, pero "no era una lengua necesaria" en la vida de Sánchez. Aún más, era una lengua relacionada con la violencia y con el castigo. De este modo, la lengua maya, hablada en la casa y en la comunidad, se convirtió en una lengua prohibida. Es ante este estatuto de inferiorización, violencia y prohibición que la revaloración de la lengua maya se ha convertido en uno de los elementos centrales en las reivindicaciones del Pueblo Maya.

Hasta que un día uno de los comerciantes del pueblo, justo cuando estábamos a la mitad de la secundaria, éramos tres los del pueblo que fuimos a Teabo a estudiar la secundaria, cuando estábamos a la mitad de la secundaria nos llamó uno de los comerciantes del pueblo porque nos escuchó platicando con un ingeniero que había llegado al pueblo para..., cuando se estaba construyendo la carretera que llegaba al pueblo. Nos llamó, nos invitó a comer en su casa. Nosotros, muy sorprendidos, fuimos los tres, y platicó con nosotros abundante mientras comíamos, hasta después de comer, nos pidió que permaneciéramos sentados, me dice: “tengo una curiosidad..., según yo — decía—, yo era el único que hablaba buen español en el pueblo, porque pues yo me paso mi vida más tiempo en Tekax — que era la cabecera- que acá en el pueblo. Pero ahora me llevo la sorpresa de que ustedes tres hablan muy bien el español, lo que quiero saber es dónde lo aprendieron". Y nosotros le decíamos: "no sé un día amanecí hablando español"; uno dijo: "no, pues en los libros que nos daban desde la primaria, estaban en español, tuvimos que aprender". Dimos distintas respuestas cada quien, lo cierto era que era manifiesto que sí ya habíamos avanzado, aunque en mi caso personal me resistía a decir que hablaba español. Un poco quizás como aún lo hago ahora. Por ejemplo, estos dos compañeros con los que yo estudié la secundaria trabajan en educación indígena, pero sus hijos no hablan, no hablan maya. En mi caso, pues, mis hijos nacieron, crecieron y toda su formación ha sido aquí en Mérida, incluso la universidad, pero todos hablan maya, ¿no?, a pesar de que nacieron y crecieron aquí.

Todo eso que me vino marcando paulatinamente en la infancia y en la juventud se fue reflejando, y cuando este encuentro con algunos compañeros que también escribían maya en el ochenta en Valladolid, me permitió ya registrar de manera consciente que escribir maya era algo 
significativo, fue que empecé entonces ya incluso a crear algunas canciones, a escribir obras de teatro, a continuar con la recopilación que venía yo haciendo de los relatos de mi pueblo, y a crear algunos poemas en lengua maya. Fue más o menos hasta el 86 , que cuando se publica esta colección de Letras Mayas Contemporáneas, es que se retoma una buena parte de mis escritos, son nueve obras de teatro, algunas fueron recopilaciones, y otras fueron escritas por mí, pero son nueve obras de teatro que se publican en la colección Letras Mayas Contemporáneas. Como que el primer momento fuerte de publicaciones de mis trabajos. Luego se publicaron varias en cosas diversos libros de antologías, en revistas y todo eso, y es hasta el 98 que entonces me animo a hacer una selección de mis poemas que termina siendo publicado por Escritores en Lenguas Indígenas, Asociación Civil, que estaba en México, que se publica finalmente este libro Ukp'éel wayak', Siete Sueños. Pero, eh, ya cuando entonces ya había superado yo ese conflicto que tenía yo con el español ¿no? Ya, además, Teabo fue el primer momento donde me vi, digamos que, obligado por el contexto sociolingüístico en el que estaba, pues a hablar mucho más en español que en maya, y después de Teabo, Valladolid, ¿no?, donde tomamos esta capacitación para promotores culturales bilingües, y después Mérida y, inmediatamente después, en el 81 , me fui a México por un año, y fueron brincos muy enormes que di, de ser de una comunidad pequeñita y casi desierta, primero fue Teabo que era una villa en aquel entonces, luego Valladolid, ciudad mediana, luego Mérida que ya empezaba a crecer Mérida de manera muy fuerte también, y terminé en el Distrito Federal, prácticamente en un plazo entre un año y medio y dos años. Fueron saltos muy enormes para mí, que el hecho de hablar en un nivel considerable el español fue lo que me ayudó mucho en ese sentido, porque bueno, en esos contextos prácticamente no tenía mucho con quien hablar maya.

Pero, esa estancia en México entre el 81 y el 82, también, como que me ayudó a entender que si podía sobrevivir en un contexto tan distinto al mío era porque me refugiaba también en la escritura. En mis ratos libres escribía en maya, en maya, en maya, en maya; incluso las pocas cartas que les mandaba a mis familiares las escribía en maya, ¿no?, entonces eso fue como que afianzando en mí la idea de ya no odiar hablar español, pero sí sentir que tenía que hacer algo yo por mi lengua propia.

En esta sección del relato aparecen elementos representativos de los cambios externos: comerciantes, ingenieros, carreteras. Junto a ellos también se aprecia un cambio en la concepción del castellano: del odio hacia dicha lengua a una gradual aceptación.

Sobre todo en estos párrafos observamos cómo Sánchez cobra mayor conciencia de que "escribir maya era algo significativo", un recurso significativo a controlar y 
movilizar, por ejemplo, a través de la creación literaria. En este proceso fue central el estado y sus instituciones y políticas culturales, particularmente la formación de promotores culturales bilingües. Así, si bien las reivindicaciones del Pueblo Maya pueden presentar un discurso crítico con respecto al estado, lo cierto es que su emergencia fue posible, en gran medida, gracias al estado. No se trata de una simple oposición - Pueblo contra el estado-, sino de una relación tensa, de constitución mutua.

Creo que a finales de los setentas, a finales de los setentas y principios de los ochentas, fue una época en la que se dieron varias circunstancias que provocaron un cambio en la política pública, o por lo menos en los planes de gobierno, a niveles tanto, tanto estatal como federal. En un principio vino de la Federación hacia, hacia los estados. A fines de los setentas, algunos años después de crear la dirección de educación indígena, se crea la Dirección General de Culturas Populares. La Dirección General de Culturas Populares se crea a nivel central, pero paulatinamente fue abriendo unidades regionales en los estados, era un proyecto planteado para fortalecer mucho la política pública en los estados donde había un considerable número de población originaria, población indígena como le llamaban en aquel entonces, ¿no? Y era un proyecto novedoso, sustentado por un primer grupo de científicos sociales en aquel entonces que intentaban revolucionar la política pública en el país para darle mayor participación a las poblaciones originarias como una respuesta a lo que desde Vasconcelos se venía impulsando, esa política de homogenizar la cultura, de hacer una cultura nacional, de castellanizar a los hablantes de lenguas originarias para crear una cultura supuestamente nacional fuerte. Entonces un grupo de científicos sociales se desprende de esa corriente y plantean una política, digamos contestataria, una política que argumentaba el derecho de los pueblos de mantener su identidad, ¿no?, es en ese contexto en donde surge la Dirección General de Culturas Populares y una de las tres primeras unidades regionales que se crean es la de Yucatán. Es en ese momento que yo me inserto en esa idea. Recién habían fracasado algunos programas también como el programa de Conasupo, había fracasado junto con un programa de teatro para las comunidades que venía impulsándose desde Conasupo. De hecho, cuando yo voy a la, al DF a fines del 81, era precisamente porque se había creado un departamento que se llamaba de arte escénico popular, en donde no se le imponía una obra de teatro a los hablantes de determinada lengua para llevar a su comunidad, sino era acompañar, a través de ese departamento, a grupos de las distintas, de los distintos pueblos de México, para que crearan una obra que consideraran pudiera ser de impacto para entender esa 
problemática de confrontación cultural que se venía dando y qué acciones podrían realizarse idealmente para fortalecer la identidad. Desafortunadamente, diría yo, para los pueblos, para los setentas, los ochentas fue cuando se empieza, empieza a haber una expansión de muchas actividades agroeconómicas en el estado. Bueno, no sólo en el estado, a nivel del país, donde se establecían los cultivos estacionarios y venía a romper con este ciclo natural del clima y el ambiente que era propicia para la producción milpera, y entonces la producción milpera se empezaba a venir para abajo y entonces había una expulsión bastante fuerte de la mano de obra joven de las comunidades, se empezaba a desarrollar las grandes metrópolis como Cancún y todo eso, había no sólo expulsión sino atracción de más mano de obra de la que podía expulsar una comunidad. Hay muchas circunstancias por allá que coincidieron para que esta política cultural que habían planteado este grupo de científicos, pudiera como que significar una alternativa para el país, ¿no? En Yucatán, nosotros recién estrenados a final de cuentas como promotores culturales de los 35 que éramos, empezamos a impulsar, en principio, los famosos encuentros de cultura maya, que era un encuentro que de pronto duraba hasta tres días en alguna comunidad, y tenían una altísima presencia la gran diversidad de manifestaciones, expresiones culturales del estado, la península de pronto, y hasta incluso en algún momento llegamos a abarcar Belice y Guatemala, ¿no? En donde pudiéramos ver, no sólo las actividades artísticas como la danza, el teatro, la literatura, la música, sino incluso cosas como los juegos tradicionales, toda la gran gama de artesanías, los conocimientos de medicina, la llamada medicina tradicional, tenían lugar en estos encuentros de cultura maya que se hacían una vez al año, itineraban en el estado una vez al año. Y se hicieron 15 en total, o sea, por 15 años consecutivos se hacía este evento, en tanto la política parecía concordante con las acciones que se proponían. Paralelo a eso yo organizaba igual de manera itinerante en el estado y anualmente los encuentros peninsulares de teatro en lengua maya, y que se hicieron siete, hasta que me fui de Yucatán en el 96.

Entonces había una política, había una serie de instancias recién creadas, había un buen grupo incluso, digo, de científicos sociales a nivel nacional que empujaban bastante al gobierno federal y que parecía que las cosas iban bien y había presupuesto obviamente para este tipo de cosas. A nivel estado, de algún modo el estado tenía que responder ante este tipo de programas y también ayudaba al desarrollo de las actividades que se planeaban en aquel entonces. Donde se veía el sesgo de la acción del estado como estado autónomo, era porque, bueno, las pocas acciones que proponía como estado no avanzaban; cuando era la Federación la que, con sus planes y programas, y algunas instancias como ésta o en aquel entonces el INI, eran los que empujaban ciertas actividades, claro, coordinado por nosotros como parte del estado, pues el estado respondía. El ejemplo más claro de este sesgo de la acción autónoma del gobierno del 
estado, por decirte, me parece que en el 83, crean un..., paralelo con otros premios literarios, el premio Itzamná de literatura lengua maya. En la convocatoria venía establecida que la instancia convocante en aquel entonces el Instituto de Cultura de Yucatán iba a publicar la obra ganadora. Y recuerdo que se hicieron como nueve concursos, uno al año, nunca se publicaron estas obras en maya, a pesar del compromiso del gobierno del estado de publicar las obras ganadoras. Nunca se publicaron estas obras. Publicó uno nada más, que se llamó Ponte esta ropa, de Jorge Echeverría Lope, pero inmediatamente que lo empezó a distribuir lo empezó a recoger, porque habían cometido cualquier cantidad de errores, entonces no se distribuyó en sí esa obra. Sin embargo, se siguieron haciendo en los años subsecuentes estos concursos del premio Itzamná de literatura en lengua maya y nunca se volvió a publicar ninguno de los resultados. Entonces eso demostraba el sesgo que tenía en su política cultural el estado.

Continuando con el análisis anterior sobre el papel del estado en las reivindicaciones étnicas, en estos pasajes podemos observar cómo el estado y sus políticas indigenistas constituyen estructuras de oportunidades para la emergencia de la etnicidad y las reivindicaciones étnicas. Por un lado, el indigenismo integracionista, a través de la castellanización y de la movilidad espacial y social, proporcionó recursos que, si bien fueron vividos como violencia y castigo, también pudieron ser controlados y movilizados posteriormente. Por otro lado, el indigenismo vinculado con el etnodesarrollo y la participación gestó las condiciones para que el control de otros recursos, como hablar y escribir la lengua maya — pero también el español—, resultara algo significativo. Esta estructura de oportunidades se vivió como un cambio desde afuera ("en un principio vino de la Federación hacia, hacia los estados").

También podemos destacar el papel que jugaron los científicos sociales en el cambio en la estructura de oportunidades que gestó las condiciones para el surgimiento de intermediarios político-culturales, como Sánchez ("es en ese momento que yo me inserto en esa idea"). Así, Sánchez se convierte en un intermediario entre el estado y las comunidades en Yucatán, a través de su trabajo en la Unidad Regional de Culturas Populares. Este trabajo de intermediación se llevó a cabo, por ejemplo, en el ámbito de las artes escénicas y de la organización de los encuentros de cultura maya. 
Y van pasando los años, las administraciones... en algún momento, no recuerdo si fue con Manzanilla Schaffer, se crea, supuestamente para que sea una instancia de interlocución entre el pueblo maya y el gobierno del estado, un organismo que se llamó Consejo Supremo Maya. Habían empezado a hacer asambleas regionales para que se nombraran a través de estas asambleas a los representantes de cada región que pudieran conformar este Consejo Supremo Maya. Pero luego se dieron cuenta que estaban resultando electos representantes distintos a los que ellos querían poner como gobierno del estado. Entonces suspenden este proceso y ellos nombran a final de cuentas a los últimos consejeros. Al final de cuentas para que este organismo sirva como un apéndice más del gobierno del estado y no como un organismo autónomo del pueblo maya de interlocución, viene un cambio de gobierno, entra Cervera Pacheco y nombra a su compadre Gaspar Antonio Xiu, éste que se hace nombrar príncipe maya, este... como presidente del Consejo Supremo Maya. Gaspar Antonio ejerce su periodo y crea paralelo a esa institución, con recurso de esa institución, otro organismo que lo veía como plataforma de modo que cuando le toque dejar el Consejo Supremo Maya ya tiene otra plataforma para impulsarse políticamente, ¿no? Y entonces, tiene un conflicto con Cervera, y Gaspar Antonio reta a Cervera, su compadre, dice "quítame si puedes del Consejo Supremo Maya". Entonces, como no lo pudo quitar, yo recuerdo que estaba en el DF, no me acuerdo muy bien si era en el 96, 97, cuando vio que no lo podía quitar, lo que hace Cervera era decretar la desaparición del Consejo Supremo Maya, la única forma de descabezar a su compadre. Y entonces, en ese momento, decreta la desaparición del Consejo Supremo Maya y crea el Indemaya. Yo estaba en el DF cuando vi la nota. Entonces, varios años, bueno, yo regreso en el 99 a Yucatán y no me acordaba del Indemaya, no me acordaba de ese episodio de que desaparecieron el Consejo Supremo Maya y crean el Indemaya, hasta que cuando entra el gobierno de Patricio Patrón Laviada, empieza a funcionar, yo ya estaba instalado nuevamente en Culturas Populares trabajando y me invitan a opinar del proyecto Indemaya. Entonces yo voy a tratar de saber de qué se trata y resulta que habían 17, 18 gentes que ya venían cobrando de Indemaya desde entonces, pero no se veía un proyecto, no se veían programas, no habían planes, no había nada. Entonces, me dicen: "queremos tu opinión del proyecto Indemaya", y digo "para dar mi opinión necesito ver la documentación", y lo que me dan es puro decreto de creación, entonces no puedo opinar del proyecto Indemaya, de lo que puedo opinar es del decreto y en su caso si ustedes quisieran, de diseñar el proyecto, "eso es justamente lo que queremos", me dicen, que se pueda diseñar el proyecto y ver cómo ponerlo en marcha. Entonces recuerdo lo que pregunté, dos cosas, le digo: ¿hay línea, línea política? No hay. ¿Hay límites? Lo que el decreto establece. Y entonces, bajo esas circunstancias es que empiezo a diseñar el proyecto de Indemaya con todo lo que pudo haber 
significado la prueba y el error de aquel entonces, pues bueno, prácticamente los primeros dos, dos años, dos, tres años, fueron responsabilidad mía en algún momento, ¿no? Y después comenzaron a entrar más gentes al Indemaya, a crecer el Indemaya. Una de las grandes ausencias que notábamos precisamente en ese momento, la ausencia de una verdadera política de atención al pueblo maya, digo verdadera, porque hasta ese momento no existía alguna instancia que atendiera al pueblo maya en lengua propia, pocos de los funcionarios conocían la cultura maya, ¿no?, lo único que conocían del pueblo maya era que la mayoría de los que se atrevían a llegar a tocar las puertas era que no hablaban español, y que era un gran problema porque no podían ni darse entender ni entender lo que se les explicaba desde los escritorios de las instituciones. Intentamos cambiar esta política con una, la primera propuesta era realizar en 2003 una consulta para saber cómo quería el pueblo maya ser atendido por el gobierno. Entonces surge ahí una propuesta de política pública de atención diferenciada al pueblo maya..., como resultado de, lo que se hizo es una propuesta descabellada a lo mejor, y eso espantó al gobierno y a los funcionarios, porque propusimos una administración pública bilingüe en el estado. Se habían identificado la mayoría de las instancias donde por sus propias necesidades, pueblo maya llegaba a esas instancias, demandaban los servicios de esas instancias, y decíamos que esas direcciones, esos departamentos, como quiera que sea, esas oficinas de gobierno, deberían contar con gente que hablara lengua maya, que conocieran al pueblo maya, que entendieran la filosofía del pueblo maya, no era simplemente, no bastaba con hablar la lengua maya si no conoces la filosofía del pueblo maya para poder dar una buena atención. Pero paralelo a eso propusimos, bueno, a los trabajadores que demostraran estas habilidades en las distintas áreas y niveles de gobierno, pudieran ser incentivados para brindar esta atención, mejorando su remuneración; por decir, una secretaria que sólo habla español iba a recibir un salario $\mathrm{x}$, una secretaria que hable maya y español de manera eficiente para atender a pueblo maya iba a recibir ese salario que recibía la secretaria más un porcentaje extra digamos. No funcionó, al gobierno le espantó la idea.

En la parte final del relato autobiográfico de Sánchez podemos observar algunas de las problemáticas de las relaciones de intermediación entre el estado y las poblaciones indígenas. Sánchez narra el caso del Consejo Supremo Maya, instancia creada para mediar "entre el pueblo maya y el gobierno del estado" y que, en la práctica, sirvió más a los intereses del gobierno del estado - como vimos en el apartado de este capítulo sobre Gaspar Antonio Xiu y la Alianza Maya. Sin embargo, tal como relata Sánchez, las relaciones entre Xiu y el gobierno del estado no estuvieron libres de tensiones. Fue a raíz 
de este conflicto que, según Sánchez, surgió el Instituto para el Desarrollo de la Cultura Maya, un actor importante para lo que sigue en esta tesis - y sobre el cual, más adelante, se podrán leer otras versiones sobre su creación.

Del mismo modo, en estas líneas hallamos una crítica de Sánchez a la política del estado con respecto al pueblo maya: "no existía alguna instancia que atendiera al pueblo maya en lengua propia, pocos de los funcionarios conocían la cultura maya". Ante esta ausencia se plantearon varias demandas o reivindicaciones: la realización de una consulta "para saber cómo quería el pueblo maya ser atendido por el gobierno", una "política pública de atención diferenciada al pueblo maya”, que las oficinas de gobierno cuenten "con gente que hablara lengua maya, que conocieran al pueblo maya, que entendieran la filosofía del pueblo maya" y que "los trabajadores que demostraran estas habilidades en las distintas áreas y niveles de gobierno, pudieran ser incentivados para brindar esta atención, mejorando su remuneración". Sin embargo, esto "no funcionó, al gobierno le espantó la idea".

Hasta aquí hemos visto el proceso de emergencia de la etnicidad maya vinculado con el fenómeno del poder. Particularmente, he expuesto el surgimiento de un conjunto de actores que se identifican como mayas y que reivindican al Pueblo Maya. El relato de Feliciano Sánchez termina haciendo referencia a la modificación a la constitución estatal de Yucatán para reconocer en ella al pueblo maya de Yucatán, llevada a cabo en 2007, así como la ley secundaria titulada "Ley para la protección de los derechos de la comunidad maya del estado de Yucatán". Sobre este proceso político de reivindicación del Pueblo Maya, así como de otros campos y arenas de reivindicaciones étnicas, versan los siguientes capítulos. 


\section{TERCERA PARTE.}

\section{LAS REIVINDICACIONES DEL PUEBLO MAYA:}

CAMPOS, ARENAS Y PROCESOS 


\section{Las reivindicaciones legales: la "Ley para la protección de los derechos de la comunidad maya del estado de Yucatán"}

\section{Introducción}

Por lo menos desde la década de los setenta del siglo XX, los derechos humanos se han convertido en una de las arenas centrales en donde se expresan y disputan las reivindicaciones étnicas en todo el mundo. ${ }^{109}$ En el caso de las reivindicaciones del Pueblo Maya de Yucatán cabe destacar la modificación de la Constitución del Estado de Yucatán mediante el Decreto 755, según el cual se reconoce la composición pluricultural de la entidad sustentada originalmente en el pueblo maya, así como la publicación de la "Ley para la protección de los derechos de la comunidad maya del estado de Yucatán" en 2011. ¿Cómo podemos entender este proceso legal, el impulso por legislar en torno a los derechos humanos de los pueblos indígenas y sus posibles alcances y consecuencias?

En torno a la legislación sobre los derechos de los pueblos indígenas solemos encontrar dos posiciones generales. Una atribuye las reformas y las leyes en la materia como un triunfo y logro de las luchas de los pueblos indígenas. La otra, en cambio, considera que las reformas y leyes responden principalmente a intereses de las clases dominantes. Una variación de este último planteamiento lo encontramos en la conocida tesis de Charles R. Hale (2002) sobre el "multiculturalismo neoliberal”, según la cual los estados reconocen ciertos derechos de los pueblos indígenas siempre y cuando no

${ }^{109}$ Como ha advertido Esteban Krotz, "Desde hace algún tiempo, la situación y los reclamos de la población indígena de América Latina y de otras partes del mundo se discute y se analiza cada vez más como problema perteneciente al tema de los 'derechos humanos"' (Krotz 2002:85). Del mismo modo, como han observado Jean y John Comaroff (2009), desde hace unas décadas presenciamos un "fetichismo de la ley", el cual se puede apreciar en las constituciones escritas y reescritas desde 1989, en el énfasis en los derechos, en la emergencia de nuevas formas de "legalidad transnacional" y de ONG orientadas hacia lo legal; en la judicialización de la política así como en la hegemonía del discurso sobre los derechos humanos. De acuerdo con ellos, "la ley" aparece en el presente más y más como un fetiche: una abstracción hecha real, una abstracción altamente animada a la cual se le atribuye la capacidad mítica, numinosa de configurar el mundo a su propia imagen (ver también Tomlins y Comaroff 2011:1067). 
contravengan los intereses de las elites políticas y económicas. De este modo, ha observado Hale para el caso de Guatemala, se han reconocido derechos culturales y lingüísticos, pero no derechos en torno a tierras, territorios y otros recursos materiales. En términos más amplios, podríamos considerar que en el fondo se encuentra el problema de la tensión en torno a si el derecho sirve como un elemento para reproducir la dominación o si puede ser un medio de emancipación. ${ }^{110}$

En este contexto de discusión, podemos preguntarnos: ¿la Ley de 2011 en torno a los derechos del pueblo maya puede entenderse como un producto de las luchas de dicho pueblo o como un acto de interés de las élites del estado? Ciertamente, los estudios sobre el tema han planteado que la ley es resultado de procesos de arriba hacia abajo y no el producto de la movilización étnica en el estado (Duarte 2013-2014; Mattiace 2013). Sin embargo, la pregunta así planteada puede conducir a simplificaciones y reduccionismos. ${ }^{111}$ Me parece que una ruta de análisis más fecunda, y que es la que aquí seguiré, consiste en analizar la ley como parte de un proceso político más amplio que

${ }^{110}$ Así, el derecho parece representar un buen ejemplo de lo que los teóricos críticos alemanes Max Horkheimer y Theodor Adorno caracterizaron como "dialéctica de la Ilustración". Al mismo tiempo que parece ser uno de los grandes logros culturales de la civilización europea, capaz de resolver los conflictos por medio de la ley y el orden y no de la violencia y la represión (ver Duve 2013), parece ser también uno de los marcos de dominación no sólo en Europa, sino también en las regiones donde se ha expandido el derecho europeo. En el terreno del derecho, los derechos humanos constituyen un caso ilustrativo de dicha dialéctica. Por un lado, la Declaración Universal de la Organización de las Naciones Unidas surgió precisamente como una respuesta al caso más emblemático de lo que Horkheimer y Adorno llamaron "barbarie": el holocausto. Desde entonces, en diversos ámbitos los derechos humanos son vistos como uno de los principales instrumentos de emancipación y justicia en el mundo. Pero también se ha señalado en diversos espacios cómo los derechos humanos son una nueva forma de colonialismo (Speed 2006). La crítica al carácter eurocéntrico y colonial de los derechos humanos no sólo se pregunta el "qué" son los derechos humanos, sino, y de manera notable, "para quién", "para qué", "desde dónde" (Barreto 2013:5-6). En el caso de México, la modificación del Artículo Cuarto de la Constitución de los Estados Unidos Mexicanos en 1992, la cual afirma que "La nación mexicana tiene una composición pluricultural sustentada originalmente en sus pueblos indígenas. La ley protegerá y promoverá el desarrollo de sus lenguas, culturas, usos, costumbres, recursos y formas específicas de organización social...", puede ser vista tanto como el resultado de la lucha de movimientos y organizaciones indígenas, como del "multiculturalismo neoliberal", pues el mismo año se reformó también el artículo 27 de la Constitución, el cual ha sido considerado como una "contrarreforma agraria". Con respecto a los estudios sobre los derechos humanos de los pueblos indígenas, Krotz (2002:86) observa dos tendencias contrapuestas. Por un lado, la referencia "a los derechos humanos como base de apoyo para todo tipo de quejas, demandas y reivindicaciones", y, por otra parte, la relativización de los derechos humanos, "considerados ante todo expresión cultural e históricamente limitada de una determinada civilización y un determinado momento histórico".

${ }^{111}$ Al respecto, Krotz (2009:13) ha observado que "el que la problemática central de esta dimensión sea expresada a menudo todavía mediante binomios de términos aparentemente opuestos — por ejemplo, Estado nacional y minorías étnicas, nación y pueblos indígenas, Estado homogéneo y Estado plural, cultura nacional y diversidad regional - es un indicio de que todavía no se ha avanzado mucho en su tratamiento conceptual". 
tiene lugar en un campo político, entendiendo la arena de los derechos humanos como un campo de lucha y, también, como una fase más en el "aún inacabado aprendizaje intercultural sobre qué es ser humano y cuáles son los principios de una convivencia humana realmente merecedora de tal nombre" (ver Krotz 2002:86).

En este sentido, podemos entender el campo político como aquel contexto social en el que necesariamente debe ser analizada la ley, teniendo en cuenta su "semiautonomía", es decir, que si bien la ley forma parte de un contexto social más amplio, también genera sus propias reglas y dinámicas, no necesariamente determinadas por la sociedad más amplia (Moore 1973:719-720).

Así, en este capítulo realizaré un análisis del proceso que dio como resultado la Ley de 2011, así como el campo político en el cual dicho proceso tuvo lugar. En primer lugar, describiré algunos de los antecedentes del proceso, ubicando a dos actores que resultaron centrales en el campo: por un lado, las organizaciones indígenas que desde finales de la década de los ochenta del siglo XX comenzaron a plantear demandas, especialmente sobre la oficialización de la lengua maya (por lo demás, una de las demandas étnicas centrales en el estado); por otro lado, los académicos que en la década de los noventa iniciaron la discusión y el análisis de los derechos de los pueblos indígenas en el estado. Si bien no podemos argumentar que la Ley de 2011 es resultado de la movilización étnica en el estado, tampoco podemos negar la importancia de algunas organizaciones indígenas así como de algunos académicos involucrados en el proceso de legislación.

En un segundo apartado describiré la entrada de un segundo actor en el campo, el estado, a través de sus instituciones indigenistas así como del Congreso. Sin duda, estos han sido unos de los actores fundamentales en el proceso; no obstante, no podemos entender al estado como un actor homogéneo, pues entre sus instituciones, así como entre las fracciones del Congreso, hay diferencias importantes que nos ayudan a entender el proceso de legislación y su resultado. En la tercera sección describiré las posiciones de los diferentes actores en el campo sobre la ley, así como la ley resultante.

En la parte final de este capítulo analizaré el material etnográfico a la luz del análisis sobre el poder planteado en esta tesis. ¿Cómo opera el control de recursos en este proceso?, ¿qué órdenes clasificatorios están en juego? Siguiendo los planteamientos de 
los Comaroff (2009; ver también Tomlins y Comaroff 2011:1065-1066), analizo qué prácticas, significados, normas, valores son hegemónicos, dados por sentado, y cuáles se encuentran en disputa ideológica. Esto resulta central toda vez que, como ha observado Sally Moore (1978), el orden social y simbólico no está simplemente dado, sino que es continuamente realizado y reiterado por procesos activos, por "procesos de regularización", de fijación de la realidad por medio de símbolos y leyes.

Podemos argumentar que la Ley se trata de un proceso político que surgió como un proceso de difusión de un drama social sucedido a nivel nacional: la ruptura estuvo marcada por la exigencia de organizaciones indígenas, académicos y políticos que reclamaron al Estado Mexicano el reconocimiento constitucional de los pueblos indígenas. Esta reivindicación gestó las condiciones para que en Yucatán emergiera un campo político y una estructura de oportunidades en torno al proceso de legislación de los derechos del pueblo maya. Dicho campo estuvo conformado por organizaciones mayas, académicos, instituciones indigenistas del Estado, el Congreso del Estado, amén de otras organizaciones de la sociedad civil. Si bien en todo este proceso no hubo marcados antagonismos y enfrentamientos, como suele ser la regla en los campos políticos, era un campo de tensiones: las organizaciones mayas, de la sociedad civil y los académicos planteaban sus demandas y propuestas a las distintas instituciones del Estado; estas últimas tampoco estaban libre de tensiones; como veremos más adelante, hubo un conflicto entre ellas que significó la retirada de una de las partes; del mismo modo, al interior del Congreso, las diferencias partidistas también significaron una tensión más en el campo.

En este orden de ideas, en este capítulo tomo distancia de los estudios de antropología jurídica que se centran en el "derecho indígena", en el "derecho consuetudinario" y/o en los "usos y costumbres" de los pueblos indígenas, los cuales, como ha observado Gabriela Torres (2014), suelen interesarse en observar la relación entre el derecho indígena prehispánico y el contemporáneo y destacar algunos de sus cambios y continuidades. En este trabajo, insisto, me centro en un campo político 
compuesto no sólo por actores indígenas, sino también por otros, y describiré la ley como un proceso político que responde a diversas perspectivas e intereses. ${ }^{112}$

\section{Antecedentes: las organizaciones indígenas y la demanda en torno a la lengua y los derechos indígenas en la academia}

La participación de los actores indígenas

Desde la década de los setenta del siglo $\mathrm{XX}$, diversas organizaciones y movimientos indígenas comenzaron a plantear sus demandas cada vez más en términos de derechos. En el caso de Yucatán, uno de los primeros antecedentes del proceso de legislación en torno a los derechos del pueblo maya del estado lo encontramos en la "Declaración de Valladolid" emitida por la Organización de Profesionistas Mayas (OPM) en octubre de 1989, en el contexto de la instalación de la Comisión Nacional de Justicia para Pueblos Indígenas en abril de ese mismo año, la cual proponía elevar a rango constitucional el reconocimiento de las comunidades indígenas en el país. En dicha declaración, la OPM proclama su adhesión y apoyo a la propuesta de reforma constitucional para reconocer los derechos culturales de los pueblos indígenas de México (ver Alonzo 1993), la cual se llevó a cabo en 1992. De acuerdo con Esteban Krotz (2015:186), la modificación constitucional de 1992 es uno de los antecedentes importantes de la Ley yucateca.

Un año después de la Declaración, en 1990 se conformó en Chichimilá, Yucatán, la asociación civil Maya’on, la organización indígena que tendría la presencia más activa en el proceso de legislación. En el capítulo anterior describí el surgimiento y la estructura de esta organización, la historia de vida de su integrante más visible, Bartolomé Alonzo, y algunas de sus acciones de reivindicación del Pueblo Maya. Ahora sólo me detendré en algunas de las acciones que han llevado a cabo en relación con la reforma constitucional y con la ley de derechos del pueblo maya.

Lo primero que podemos destacar es que Maya'on ha recurrido al discurso de los derechos de los pueblos indígenas así como a los tratados internacionales en la materia para plantear sus demandas. ${ }^{113}$ De acuerdo con Bartolomé Alonzo:

\footnotetext{
${ }^{112}$ Para esta perspectiva me han sido de utilidad los trabajos del politólogo David Recondo (2007) sobre la ley en Oaxaca; de Juan Carlos Martínez (2012) sobre el campo jurídico en Oaxaca; así como los trabajos de Esteban Krotz y Shannan Mattiace sobre Yucatán que son abordados en este capítulo.
} 
Lo más fuerte del planteamiento [de Maya'on] es llegar a construir una sociedad, un estado multiétnico, lo que implica una participación autónoma, implica descolonización, que los modelos de desarrollo no sean destinados desde fuera, se necesita un proyecto histórico. Maya'on se basa en instrumentos internacionales, como el convenio 169 de la OIT, el pacto de San José, sobre derechos económicos, políticos y sociales. Todo esto para lograr una identidad del pueblo maya, su participación, su autonomía. Así, las demandas por la oficialización de la lengua maya, de la educación bilingüe intercultural, son sólo los medios, no las metas. ${ }^{114}$

La demanda central de Maya'on ha sido la oficialización de la lengua maya así como el desarrollo de la educación intercultural y bilingüe, para lo cual han organizado una serie de foros y han publicado textos en la prensa ${ }^{115}$. De acuerdo con uno de sus integrantes más activos, la acción más relevante de Maya’on para lograr la oficialización de la lengua maya ha sido la elaboración del documento "Bases para la Oficialización del Mayathaan”, publicado el 12 de octubre de 1991 con la colaboración del Programa de Apoyo a las Culturas Municipales y Comunitarias (PACMYC). En este documento se plantea la demanda de oficialización de la lengua maya en los tres estados de la península (Alonzo 2008:206), con lo que se busca transformar las estructuras de poder institucionalizadas, que desde el nivel jurídico excluyen y discriminan a la población indígena. Otra de las actividades para la revitalización de la lengua maya fue la organización de talleres de lectoescritura en lengua maya durante el ciclo escolar 19931994 (Leirana 2001:132). Asimismo, desde 2001, Maya’on ha participado en la organización de los encuentros de los pueblos mayas de México, Guatemala y Belice, ${ }^{116}$ en donde el tema de los derechos de los pueblos indígenas han sido uno de los principales tópicos de discusión. Así, por ejemplo, en la "Declaración de Zaci III”, resultado del Décimo Encuentro Lingüístico y Cultural del Pueblo Maya realizado del 28 al 31 de julio

\footnotetext{
${ }^{113} \mathrm{Y}$, en términos de poder como control de recursos, Rachel Sieder y Jessica Witchell (2001) han apreciado que las ideas de pluralismo cultural, de derechos humanos y de derechos indígenas se han convertido en recursos para los grupos indígenas, son una fuente de legitimidad de su lucha.

${ }^{114}$ Entrevista con B. Alonzo, Valladolid, Yucatán, 2009.

115 Del mismo modo, un aspecto relevante de Mayáon es el papel que le otorgan a la historia. sobre la historia (énfasis en el aspecto neo-colonial de la historia.

${ }^{116}$ Los encuentros fueron realizados en (año y lugar): 2001, Guatemala; 2002, Valladolid, Yucatán, México; 2003, Belice; 2004, Guatemala; 2005, Felipe Carrillo Puerto, Quintana Roo, México; 2006, Campeche, Campeche, México; 2007, Belice; 2008, Guatemala; 2009, Chiapas, México; 2010, Valladolid, Yucatán, México. Fuente: entrevista con B. Alonzo, 2009.
} 
de 2010 en Valladolid, se hace referencia en primer lugar a los instrumentos jurídicos internacionales y nacionales ${ }^{117}$ y se plantea que

trabajaremos sin descanso hasta lograr que exista en nuestros países y entidades un marco jurídico que garantice a las comunidades mayas el ejercicio pleno de sus derechos humanos fundamentales; un marco jurídico que elimine toda forma de discriminación e impulse la participación efectiva de las comunidades mayas en la toma de decisiones en los asuntos de interés público.

En este orden de ideas, se plantean varias gestiones en la agenda del pueblo maya, clasificadas en cada país, Belice, Guatemala y México. Las relativas a México son, primero, la solicitud de que los gobiernos de los estados de Yucatán, Campeche, Quintana Roo, Tabasco, Chiapas y San Luis Potosí consoliden el proceso de reconocimiento jurídico de los derechos de las comunidades mayas; para el caso particular de Yucatán, exigieron la publicación en el Diario Oficial de la Ley de Derechos y Cultura del Pueblo Maya; también plantean la solicitud al Poder Legislativo de México para que se reserve el 30\% del espectro radioeléctrico para las estaciones de radio comunitarias e indígenas y el 1\% del presupuesto de comunicación social de los tres niveles de gobierno para los medios de comunicación en lenguas indígenas; demandan seguimiento y solución por parte de las autoridades correspondientes a la queja presentada antes las comisiones de derechos humanos por el caso de represión ejercida contra campesinos mayas el 24 de mayo de 2009 en el municipio de Felipe Carrillo Puerto, Quintana Roo, y el cese al hostigamiento judicial a sus líderes; el acceso libre a los sitios sagrados mayas y centros arqueológicos; la creación de la carrera profesional en Derecho Indígena Intercultural; que las instituciones públicas de salud promuevan el desarrollo y aplicación de la medicina maya, así como la creación de la carrera profesional de Medicina Maya con enfoque intercultural; crear programas y espacios comunitarios para el fomento de la medicina maya; un marco jurídico y políticas públicas

\footnotetext{
117 Tales como la Declaración de las Naciones Unidas sobre los Derechos de los Pueblos Indígenas; la Declaración Universal de los Derechos Lingüísticos, proclamada por la Conferencia Mundial de Derechos Lingüísticos, Barcelona, España, 1996; la Declaración sobre los Derechos de las Personas Pertenecientes a Minorías Nacionales o Étnicas, Religiosas y Lingüísticas, resolución aprobada por la Asamblea General de la Naciones Unidas, 1992; el Convenio 169 de la Organización Internacional del Trabajo sobre Pueblos Indígenas y Tribales en Países Independientes, entre otros; así como los marcos jurídicos nacionales de los países con población maya.
} 
que den un nuevo impulso a una educación maya intercultural, lo que implica que se incluya en los currícula de todos los niveles educativos la enseñanza de las lenguas mayas, la historia de la civilización maya, de los sistemas de numeración y los calendarios mayas; la creación de un centro de altos estudios en la "ciudad sagrada de Chichén Itzá"; la elaboración de un calendario cívico en el cual se incluyan los acontecimientos históricos más importantes del Pueblo Maya, con el objeto de seguir fortaleciendo la memoria histórica y la conciencia de identidad de las nuevas generaciones; retomar y desarrollar los juegos tradicionales y ceremoniales propios de la cultura maya; la normalización y desarrollo de las lenguas mayas y la implementación de políticas lingüísticas que garanticen "la revitalización de nuestros idiomas"; la revaloración, preservación y desarrollo de los conocimientos tradicionales y aportes de las comunidades mayas en materia de producción agropecuaria, así como el uso y mantenimiento de semillas criollas, técnicas y sistemas productivos sustentables que contrarrestan los efectos del cambio climático y, por último, garantizar la autonomía alimentaria.

Ante esta amplia diversidad de demandas hay que observar también que las reivindicaciones étnicas en Yucatán no son homogéneas. Por ejemplo, el énfasis de Maya'on en los temas “culturales" y lingüísticos le ha costado ciertas críticas por parte de integrantes de otras organizaciones indígenas en la península. Así, miembros de la organización más reciente Kuxa'ano'on A.C. me han comentado que es necesario que los encuentros lingüísticos y culturales del pueblo maya también sean encuentros políticos y que se discuta la creación de un partido político maya. Desde su punto de vista, el trabajo por la cultura y la lengua no es suficiente para una transformación sustancial de la situación del Pueblo Maya, resulta fundamental también el trabajo (formalmente) político.

Del mismo modo, Freddy Poot, miembro del Movimiento Indígena Nacional, me señaló en una entrevista que

Hay un movimiento disfrazado como cultural, el más conocido, Maya’on, está en Valladolid. Son profesores de educación indígena, o ex-profesores de educación indígena, como Bartolomé Alonzo Caamal, Isabel, y otros. De manera general plantean la reivindicación del pueblo maya a nivel internacional, han realizado encuentros internacionales, en México, Guatemala y Belice, pero únicamente han planteado 
problemas, no se han planteado acciones concretas, no hay un aterrizaje. Tienen una actitud muy institucional, cuidan no romper con las institucionales, sino quién va a dar la lana. Esto ha ocasionado que no haya un movimiento reivindicativo de carácter político. Todo se plantea casi de manera académica, no como acción. Yo he participado en los encuentros que organizan, he estado en varios; estuvo como co-organizador en el de Valladolid en el 2002, y en el último en Valladolid en el 2011 [RL: fue en 2010].

En este punto, vale la pena tener en cuenta la observación de Patricia Richards (2004) con respecto a las demandas de los movimientos indígenas y derechos de los mapuche. Según Richards, la diversidad de las demandas de los mapuche abre la oportunidad al Estado chileno de responder las demandas que fomentan la integración y minimizan o deslegitiman las demandas más radicales de reconocimiento y autonomía. Como veremos más adelante, en Yucatán, el estado ha recuperado las demandas de las organizaciones indígenas centradas en los ámbitos culturales y lingüísticos, desdeñando las más explícitamente políticas.

Como se puede apreciar, si bien en Yucatán no encontramos un amplio movimiento étnico, organizaciones como Maya'on han participado de manera activa en la organización de eventos así como en la publicación de textos encaminados hacia el reconocimiento legal de los derechos de los pueblos indígenas en el estado. Sin embargo, ellos son solo un actor entre otros en el campo político en el cual tuvo lugar el proceso de legislación.

\section{Los derechos de los pueblos indígenas en la academia}

He argumentado que la ley y el proceso mismo de legislación no puede entenderse simplemente como producto de las luchas y demandas de los movimientos indígenas, o como una serie de concesiones de un gobierno multiculturalista neoliberal. Más bien, debemos atender al campo de actores involucrados en el proceso, en el cual cabe destacar la participación de los académicos. En este campo de fuerzas, los académicos cuentan con un recurso que puede ser caracterizado, en términos de Pierre Bourdieu (2003), como "capital científico", es decir, como un conjunto de conocimientos, relaciones y distinciones que los legitiman para hablar sobre ciertos temas, amén de otros recursos como relaciones sociales con otros actores e instituciones. Ahora cabe preguntarse ¿qué papel han jugado los 
académicos en este proceso?

Acaso lo primero que haya que señalar es que, al menos desde el levantamiento del Ejército Zapatista de Liberación Nacional en enero de 1994, el llamado "problema indígena" volvió a cobrar notoriedad en la agenda pública y, también, en la academia. ${ }^{118}$ En este contexto, puede apreciarse un giro en las ciencias antropológicas en Yucatán de los intereses socio-económicos centrados en los problemas de "clase" hacia un nuevo giro cultural, en donde la dimensión étnica de la población indígena vuelve a ser centro de interés, como se puede advertir en el creciente número de estudios sobre identidad étnica maya desde la década de los noventa (ver Krotz y Llanes 2011). Del mismo modo, ante este giro cultural, temas como la democracia, los derechos humanos y el multiculturalismo se han vuelto no solamente materia de estudio, sino de acción y cooperación con distintos tipos de agencias y organizaciones (ver Krotz 2004b; Reygadas 2007). ${ }^{119}$ Hay que aclarar que, en un contexto en el que la "antropología académica" (Reygadas 2007; Sariego 2007) es hegemónica, es decir, en donde impera cierto encierro de la academia en sí misma, son contados los académicos que han participado en estos procesos políticos en Yucatán.

Así, académicos de dependencias e instituciones como la Facultad de Ciencias Antropológicas (FCA) y la Unidad de Ciencias Sociales (UCS) de la Universidad Autónoma de Yucatán (UADY), el Centro Regional del Instituto Nacional de Antropología e Historia (INAH) y la Unidad Peninsular del Centro de Investigaciones y Estudios Superiores en Antropología Social (CIESAS), han llevado a cabo proyectos de investigación sobre la población maya de Yucatán y han sido consultados por el Congreso del Estado en el proceso de legislación de los derechos de los pueblos indígenas.

Del mismo modo, y como ya se ha señalado en este capítulo, el "problema indígena" ha sido planteado desde entonces, en buena medida, en términos jurídicos. En este sentido, cabe tener en mente que, desde algunos años atrás, como ha observado Luis Vázquez León (2002), diversos antropólogos comenzaron trabajar en el campo aplicado de la antropología jurídica. En Yucatán, uno de los académicos que se ha dedicado desde hace unas décadas al campo de la antropología jurídica y, particularmente, al de los derechos humanos, derechos de

\footnotetext{
${ }^{118}$ De acuerdo con Krotz (2015:187), el levantamiento del EZLN y los posteriores Acuerdos de San Andrés son dos antecedentes claves en el proceso de legislación yucateco.

${ }^{119}$ Al respecto, pueden tomarse en cuenta las consideraciones críticas de Terence Turner (1993) sobre la participación de los antropólogos en el tema del multiculturalismo.
} 
los pueblos indígenas e interculturalidad, es el antropólogo y filósofo Esteban Krotz, de la Universidad Autónoma de Yucatán. Desde mediados de la década de los noventa ha publicado textos que invitan al diálogo intercultural, la instauración de mecanismos que permitan la participación política indígena, así como a la reforma constitucional y promulgación de una ley en materia de derechos indígenas (Krotz 1996). Del mismo modo, entre 2006 y 2011 dirigió el proyecto de investigación colectivo "La cultura maya yucateca ante las modificaciones constitucionales y legales en proceso", en el Cuerpo Académico Identidad y Cultura Maya de la UCS. Como pude apreciar en entrevistas con diputados e integrantes de organizaciones mayas, sus planteamientos han sido una referencia importante en las discusiones sobre el tema en Yucatán y él mismo ha participado en foros y reuniones de propuestas y análisis sobre la materia. Veamos entonces cuáles son algunos de sus principales argumentos al respecto.

Krotz ha planteado que el denominado "problema indígena" no es el problema de un segmento poblacional específico de la sociedad, sino que se trata de un problema de modelo de país, que tiene sus orígenes en el colonialismo, y que tiene que ser superado a partir de la creación de lo que Guillermo Bonfil denominaba un "nuevo proyecto civilizatorio" (Krotz 1996:27; 2008). Asimismo, ha propuesto ubicar el debate actual sobre los derechos de los pueblos indígenas en el contexto de un largo proceso de diálogo y aprendizaje intercultural (Krotz 2002; 2004b), en el que no sólo se han vivido distintas "generaciones" de derechos humanos, sino que también han emergido diversos actores, que suelen ser los oprimidos de la historia, como los indígenas, para expresar sus visiones ideales de ser humano y de "una convivencia humana realmente merecedora de tal nombre" (2004b:76); se trata de un proceso por definición incompleto y abierto e incluso, advierte Krotz, a menudo bastante doloroso.

Krotz también ofrece una justificación teórica y política del problema del reconocimiento jurídico de los derechos indígenas. En primer lugar, porque la diversidad cultural o el multiverso cultural es una suerte de laboratorio de la vida feliz (Krotz 2003; 2009). ${ }^{120}$ Pero también porque las culturas indígenas

\footnotetext{
${ }^{120}$ Un aspecto que cabe subrayar aquí es la relación entre lenguaje, cultura y pensamiento (Krotz 1996), ya que, como enseñó la antropología cultural boasiana, cada cultura y lengua plantean una particular visión del mundo, por lo que un multiverso cultural resulta un laboratorio de formas de ver el mundo.
} 
a menudo parecen cultivar principios y generar dinámicas alternativas precisamente allá donde nuestras sociedades no-indígenas - modernas, estatales, nacionales, urbanas, industriales - muestran sus lados más oscuros, por ejemplo, en cuanto a la relación entre sociedad y naturaleza, en cuanto a las concepciones del tiempo (de su sentido, de su ritmo, de su valor) y de la muerte (fase humana final de una vida humana en vez de deceso a causa de un defecto fisiológico) o en el ejercicio del poder público (por ejemplo, al anteponer en la respuesta a determinados delitos la restitución al castigo) [...] Decir esto no significa idealizar culturas indígenas actualmente existentes o ya desaparecidas [...] Sí significa la afirmación de que a partir de la experiencia humana plasmada en culturas diferentes se pueden obtener impulsos importantes para re-orientar la acción colectiva e ilustrar la urgente reforma necesaria de la organización social vigente (Krotz 2009:23).

Así, el reconocimiento de los derechos indígenas se vuelve un elemento necesario y fundamental ante la actual crisis civilizatoria, ya que de algunas prácticas indígenas se pueden retomar elementos para la construcción de una alternativa civilizatoria. Para poder iniciar un diálogo intercultural Krotz propone: 1) la educación bilingüe y bicultural para todas las escuelas del campo y de la ciudad y en todos los sistemas y niveles; 2) la fundación de un centro de estudios y de documentación sobre la cultura maya; 3) el establecimiento de estrategias efectivas de actualización, sistematización y difusión especializada de la lengua maya, "elemento central de la cultura maya y objeto de múltiples reclamos" (2005:9); 4) la reversión efectiva de la marginación educativa y científica de la población maya mediante un sistema de becas especiales y suficientes en todos los niveles; y la adjudicación de partidas presupuestales en todos los ámbitos que no solamente correspondan al porcentaje de población maya con respecto a la población total del estado de Yucatán, sino que además compensen y reviertan su historia de marginación y despojo $(2005: 9 ; 2008)$.

Además de la publicación de textos sobre el tema, Krotz ha participado activamente en las actividades de propuestas sobre la ley. Como mencioné anteriormente, en mi trabajo de campo en el Congreso del Estado en Mérida pude apreciar cómo sus propuestas eran constantemente retomadas por los legisladores y otros académicos. Por esa razón me detengo un momento en ellas. Entre sus propuestas encontramos: primero, 
el reconocimiento de la composición pluricultural de la población yucateca, de un nuevo sujeto de derecho, que haga de la lengua maya la segunda lengua oficial del estado, ${ }^{121}$ pero sin excluir el reconocimiento a integrantes de otras etnias indígenas mexicanas que viven en el estado (2005:7); una oportunidad de revertir la "fragmentación del pueblo maya", es decir, la división político-administrativa en tres entidades federativas diferentes que, "desde el punto de vista del pueblo maya, [es] una expresión clara y continuada del colonialismo" (2005:8), para lo que tendría que conformarse agendas de trabajo de comisiones legislativas abocadas a la particularidad y los derechos de la población indígena y que sean "las mismas leyes" para los tres estados de la península (2005:8).

Otros académicos que participaron de manera activa en el proceso de legislación y cuyas opiniones fueron constantemente retomadas son el magistrado Pablo Monroy y el lingüista Fidencio Briceño, del INAH. Abogado originario del Distrito Federal, Monroy llegó a Yucatán en 1994. Para él hay dos temas torales en el problema de los derechos del Pueblo Maya. El primero es si el grupo maya es sujeto de derecho público o entidad de derecho público; el segundo es el relativo a los sistemas normativos indígenas. Para Monroy:

En la justicia dominante lo que se busca es castigar al culpable; en los sistemas normativos indígenas es solucionar conflictos entre la comunidad, que se repare el daño, se privilegia la conciliación y la mediación. Ahora que el sistema de justicia dominante está en crisis, y ha visto que sus procedimientos son erróneos, buscan en los juicios orales y en los medios alternativos de solución de conflictos, pero no porque cambien su forma de ver el mundo, sino porque ven que es una opción más barata, más barato que realizar grandes juicios, mantener presos, etc. ${ }^{122}$

Me interesa destacar cómo Monroy concibe el problema de los derechos del Pueblo Maya en

\footnotetext{
${ }^{121}$ De acuerdo con Krotz, "en vista de que la lengua maya ha estado desde hace mucho en el centro de las demandas de la población maya, es pertinente declarar la lengua maya segunda (aunque históricamente haya sido primera) lengua oficial en el Estado de Yucatán" (2008:7). Para Krotz, una medida concreta podría ser la oficialización de la Academia de la Lengua Maya como un organismo financiado por el Estado de Yucatán y la ampliación significativa de sus actividades (difusión de materiales lingüísticos básicos, generación de materiales especializados para el aprendizaje de la lengua maya) (2008:7) (uso de la Internet para la difusión y actualización de la lengua maya, creación de diccionarios especializados, creación e impartición masiva de cursos de etimología maya) (2008:8).

${ }^{122}$ Entrevista con Pablo Monroy, Instituto de la Judicatura Federal Extensión Yucatán, Mérida, Yuc., 28 de mayo de 2009 .
} 
términos "culturales". En una entrevista me comentó que

Ahora bien, en el peritaje antropológico suele haber una confusión. Hay que distinguir entre las condiciones sociales y la cultura. Muchas veces los antropólogos dicen que los indígenas viven en pobreza, falta de educación, etc., y así justifican algunas conductas ilícitas. Y muchas veces eso es cierto, pero no son las condiciones sociales lo que nos interesa en los peritajes antropológicos, sino la cultura, el modo de ver el mundo de los indígenas. Aquí lo que nos interesa conocer es el sistema normativo que tienen los indígenas, no si fueron a la escuela o no. El dictamen que se espera es en diferencia cultural, la concepción del mundo de los indígenas.

Así, para Monroy, un aspecto central en la legislación es tomar en cuenta el aspecto cultural del sistema normativo del Pueblo Maya. Del mismo modo, como veremos más adelante, Monroy jugó un papel importante en el hecho de que la figura de los "Jueces Mayas" (una reelaboración de los jueces de paz) fueran elegidos por las comunidades y no por el Tribunal Superior de Justicia, como se propuso en una iniciativa de ley.

Por su parte, el lingüista Fidencio Briceño, quien se identifica como maya y se ha especializado en el estudio de la lengua y cosmovisión maya, ha argumentado que "en la lengua maya está la vida, la fuerza de los mayas, con ella se muestra su identidad”. Para él, uno de los elementos centrales que se debían contemplar en la legislación es una política pública intercultural, que considere el eje lengua-cultura, así como las asimetrías entre las lenguas; una de sus propuestas principales en el proceso de legislación fue la creación del Instituto Peninsular de la Lengua Maya, enfatizando su carácter peninsular y no estatal, ya que se trata de una lengua a nivel peninsular. El Instituto no fue contemplado en la ley que resultó del proceso legislativo. Del mismo modo, ha propuesto hacer oficial y obligatoria la lengua maya en todos los contextos comunicativos; lograr una verdadera educación bilingüe; así como la formación de cuadros que atiendan las necesidades de los mayas actuales. Cabe destacar que Briceño ha jugado un papel muy importante en el campo jurídico al traducir textos jurídicos a la lengua maya, como la Ley general de derechos lingüísticos de los pueblos indígenas.

\section{Hacia la reforma constitucional}

Tras la ratificación de México del convenio 169 de la Organización Internacional del Trabajo, 
se realizó una reforma al Artículo Cuarto de la Constitución de los Estados Unidos Mexicanos para reconocer la composición pluricultural de la nación mexicana, sustentada originalmente en sus pueblos indígenas, justo el mismo año que se aprobó la reforma al artículo 27 constitucional. Asimismo, tras el levantamiento del EZLN en enero de 1994 así como de los incumplidos Acuerdos de San Andrés en 1996, se llevó a cabo una nueva reforma constitucional en 2001 que reconocía los derechos de los pueblos indígenas a la autonomía y libre determinación. Esta última reforma hacía responsable a las entidades federativas de legislar sobre derechos indígenas, aunque años antes algunas entidades ya habían realizado reformas y aprobado leyes sobre la materia (como Oaxaca, Chiapas, Campeche en 1996 y Quintana Roo en 1997). Como ha observado Krotz (2015:186 y ss), todos estos elementos fueron antecedentes importantes del proceso de legislación yucateco.

Antes de describir el papel del estado en el proceso de legislación vale la pena hacer una aclaración teórico-metodológica. En ocasiones, en los discursos de las reivindicaciones étnicas — como se podrá apreciar en el capítulo $\mathrm{V}$ de esta tesis—, el estado aparece como una entidad fetichizada: es decir, a pesar de que es producto de los hombres, se concibe como una entidad por encima de los individuos. Como han observado James Ferguson y Akhil Gupta (2002), el estado suele ser pensado a partir de metáforas de verticalidad, es visto como algo que está por "arriba" de la sociedad civil, la cual se encuentra "abajo". El discurso zapatista, por ejemplo, reproduce estas concepciones verticales sobre el estado, como cuando expresan que "donde los de arriba destruyen los de abajo reconstruimos".

Entonces, lo primero que debemos hacer para el análisis del estado es una crítica al fetichismo del estado. Una forma de ejercer esta crítica es concebirlo como un campo de fuerzas en donde están en disputa corrientes progresistas y democráticas con regresivas y autoritarias (ver Bourdieu 2014). En el caso de Yucatán, encontramos un contexto político marcadamente bipartidista entre el PRI y el PAN (ver Poot Capetillo 2013), y es en el marco de dichas tensiones que el proceso legislativo debe ser analizado.

Del mismo modo, cabe recordar que el proceso de legislación, entendido como un drama social, tuvo su origen principalmente como un proceso de difusión, es decir, que "llegó desde afuera". En entrevistas con diputados que participaron en el proceso legislativo, la mayoría de ellos consideraba que la preocupación por el tema de los derechos indígenas no provenía de las comunidades mayas — uno declaró que "aquí no es Chiapas”-, sino de 
preocupaciones externas, principalmente en el marco de la reforma constitucional de 2001.

Es en este contexto que comenzaron a realizarse en Yucatán diversos eventos de discusión y análisis sobre el tema de los derechos de la población maya. Entre ellos, cabe destacar el organizado por el Instituto Nacional Indigenista (INI) y el consejo consultivo de Radio Xepet "La voz de los mayas", "Foro estatal sobre derechos y cultura de los pueblos mayas de Yucatán y su reconocimiento en la constitución del Estado" en la ciudad de Mérida en 2001. En el foro participaron 46 servidores públicos, 15 investigadores, 6 participantes de institutos de educación superior, 18 estudiantes de preparatoria, 2 estudiantes de colegios de bachilleres, 1 estudiante de secundaria, 1 estudiante de la escuela de trabajo social, 50 participantes de asociaciones civiles, 140 participantes de organizaciones indígenas, 15 presidentes municipales, y miembros de partidos políticos, de los que no cuento con el número. Se organizaron 8 conferencias magistrales y 6 mesas de trabajo: 1. "La reforma constitucional en el ámbito federal y el reconocimiento jurídico de los mayas en la legislación estatal"; 2. "Administración de centros arqueológicos y religiosos por parte de las comunidades mayas"; 3. "Explotación, uso y disfrute de los recursos naturales en la jurisdicción de las comunidades mayas"; 4. "Derecho a la información y acceso de los mayas a los medios de comunicación, escritos y electrónicos"; 5. "Educación en el marco del respeto a la identidad cultural del pueblo maya"; y 6. "Procuración de justicia e identidad de género". Las principales propuestas y demandas planteadas fueron, en primer lugar, el reconocimiento del pueblo maya en la Constitución y la oficialización de la lengua maya. En cuanto a los centros arqueológicos y religiosos, se propuso que las comunidades indígenas sean las principales beneficiarias de sus utilidades así como su libre acceso a ellos. Del mismo modo, se demandó que las comunidades sean las principales beneficiarias de la explotación de los recursos localizados en sus territorios, así como el fomento de las plantas medicinales. En cuanto a los medios de comunicación, el grueso de las demandas estaba dirigido hacia la radio, a la consecución de más espacios en lengua maya y con contenidos sobre cultura e historia del pueblo maya. Sobre educación intercultural se propuso principalmente que ésta no sea sólo para los mayas, sino para toda la sociedad, que sea impartida en todos los niveles educativos, que se brinde atención a los estudiantes en su lengua materna (pensando sobre todo en el caso de los estudiantes mayahablantes), así como que los profesores que 
trabajen en comunidades indígenas sepan leer y escribir en lengua maya. Por último, se exigió una mayor equidad de género y el respeto de los derechos de las mujeres mayas, con énfasis en los derechos laborales. ${ }^{123}$

Podemos apreciar algunos cambios en la estructura de poder de Yucatán durante el proceso de legislación de derechos indígenas. No resulta menor que, para llevar a cabo la modificación a la constitución, fueran creadas dos nuevas instituciones del estado: el Instituto para el Desarrollo de la Cultura Maya de Yucatán (Indemaya) y la Comisión Especial de Asuntos Étnicos (Mattiace 2013). No obstante, una pregunta central que hay que tener en mente es en qué medida la creación de estas dos instituciones y la distribución de recursos que supuso ha permitido un mayor control de recursos significativos - $-\mathrm{y}$, por tanto, ejercer poder - a los actores mayas y en qué medida ha sido una estrategia "gatopardista" (Recondo 2007) del estado para simular un cambio en la materia sin llevar a cabo ninguna transformación de fondo. Veamos.

Como vimos en el capítulo anterior, el Indemaya fue creado en diciembre de 2000 $\mathrm{y}$, de acuerdo con los funcionarios de la misma institución, fue fundado para tomar ventaja de los fondos federales tras la reforma constitucional federal del 2001 (Mattiace 2009:11). De acuerdo con uno de sus primeros funcionarios, el instituto fue concebido por el gobernador Víctor Cervera Pacheco (del PRI) como sustituto de Alianza Maya, tras el conflicto que tuvo con su principal líder, Gaspar Antonio Xiu (ver capítulo anterior). Cabe observar que el instituto se ha centrado sobre todo en temas culturales y lingüísticos y una de sus campañas más notorias ha sido la de "Aquí estamos", cuyo objetivo es elevar el autoestima de la población maya; también ha sido la instancia a través de la cual el gobierno ha trabajado para realizar consultas sobre derechos indígenas.

La otra institución estatal clave en el proceso de legislación fue la Comisión Especial de Asuntos Étnicos en el H. Congreso del Estado, constituida en 2004. De acuerdo con su primer presidente, el diputado del PAN Juan Manuel Valencia, el PRI fue el que más presionó para la formación de esta comisión con el fin de recuperar votos rurales tras la pérdida de la gubernatura en el 2000 (Mattiace 2009:15). "Los diputados priistas vieron el avance en materia de derechos indígenas como una forma de revitalizar sus bases rurales" (Mattiace

\footnotetext{
${ }^{123}$ Del mismo modo, en noviembre y diciembre de 2003 se organizaron los foros "Políticas Públicas para el Desarrollo del Pueblo Maya de Yucatán” (Izquierdo 2007).
} 
2009:15). Así, desde la perspectiva de los funcionarios y diputados, la creación de estas dos instituciones respondió a pugnas políticas en el Estado: entre el PAN y el PRI, así como al interior de este último partido. Sin embargo, como veremos más adelante, las diferencias partidistas no se tradujeron en concepciones distintas sobre los derechos indígenas, y ambas fracciones concebían el tema en términos notablemente culturalistas y paternalistas.

A mediados de noviembre de 2004, la Comisión presentó su programa de trabajo, el cual contemplaba una serie de foros y consultas en seis mesas de trabajo con el objeto de contar con una ley sobre los derechos del pueblo maya y el fortalecimiento de su cultura. De acuerdo con el programa, la parte medular del trabajo de la Comisión sería una consulta pública que les permitiera escuchar y tomar la opinión directa del pueblo maya sobre su costumbre jurídica y la relación de ésta con la justicia. Dicha consulta sería desarrollada en coordinación con el Indemaya. Las mesas de trabajo serían sobre "Lengua maya y medios de comunicación”, "Discriminación, justicia, ciudadanía, interlocución, representatividad y participación", "Mujer, ancianos, niños y educación", “Territorialidad, recursos naturales, salud y medicina tradicional", "Desarrollo integral, desarrollo económico y migración" y "Patrimonio cultural y artesanía". La Comisión también llevó a cabo una exposición fotográfica sobre milperos de Yucatán, con el objetivo de sensibilizar a los diputados sobre la cultura maya y la urgencia de legislar a su favor. ${ }^{124}$

Así, en febrero y marzo de 2005 se realizó la "Consulta sobre las Iniciativas de Reforma Constitucional y la Ley de Derechos y Cultura Maya del Estado de Yucatán”, convocada por el Poder Ejecutivo del Estado por conducto del Indemaya, el H. Congreso del Estado y la CDI. En este proceso se desataron desacuerdos y tensiones entre el Indemaya y la CDI. A juicio de funcionarios de la CDI, la iniciativa que el Indemaya presentó en 2004 no incluía temas de gran relevancia tratados en los Acuerdos de San Andrés como la autonomía y las tierras. Tras estos desacuerdos, la participación de la CDI en el proceso disminuyó en los años siguientes y sólo volvió a participar de manera más activa hacia 2010 y 2011. Del mismo modo, una de las organizaciones no gubernamentales que había participado en el proceso y que, desde años antes, había trabajado en el tema de los derechos humanos, Equipo Indignación, A.C., se retiró del proceso al considerar que los temas fundamentales abordados

124 "Foros y consulta sobre derechos de los mayas". Consultado en: $<$ http://www.mayas.uady.mx/breves/nov2004.html $>$. 
en los Acuerdos de San Andrés no estaban siendo tratados. Este hecho no resulta menor, pues Indignación ha sido una de las organizaciones que, en los hechos, ha jugado un papel central en la defensa de los derechos de los maya hablantes. Por ejemplo, en 2012, publicó un documento titulado "Informe y análisis sobre las violaciones al derecho del pueblo maya al elegir autoridades en las comisarías de Yucatán". ${ }^{125}$ Del mismo modo, en fechas más recientes, Indignación publicó el libro Rebelión y resistencia del Pueblo Maya (Equipo Indignación 2014), en donde documentan historias de defensa del territorio, así como diversas leyes y declaraciones en materia de derechos de los pueblos indígenas. Así, la salida de Indignación en el proceso de legislación resulta ilustrativo del carácter que el proceso tomó: los planteamientos sobre autonomía y defensa del territorio, amén de otros derechos, quedaron de lado o apenas contemplados.

Maya'on participó en el proceso de legislación al asistir a dos reuniones de consulta que convocaron Indemaya y la CDI. De acuerdo con Bartolomé Alonzo, en las reuniones hubo poca participación de organizaciones y la gente de las comunidades no mostró mucho interés en el tema, pues están más preocupados por programas como Procampo y Oportunidades que por los temas de identidad y derechos. De este modo, la CDI tuvo que "acarrear" comisarios, ofreciéndoles comida.

Valga una digresión. Queda como un tema pendiente profundizar en el análisis de las consultas llevadas a cabo durante el proceso legislativo, ya que son prácticas que resultan fundamentales en la formulación y reconocimiento de derechos. No me lo propuse en mi proyecto de investigación. No obstante, sí puedo destacar por lo menos dos sentidos de la consulta que observé en el proceso. Uno de ellos era notablemente "clientelar". No se concebía la consulta como un ejercicio democrático, sino como una actividad del gobierno de la cual la población local podía obtener algún beneficio. Otro sentido era el de la consulta médica. En un par de consultas, los presuntos consultados pensaban que el evento se trataba de una consulta médica, por lo que sugerían que fueran los enfermos los que asistieran al evento. Profundizar en los sentidos locales de las consultas, así como en sus formas de organización, resulta crucial para poder trabajar en un proceso más democrático de formulación y reconocimiento de derechos.

125 Disponible en su página de Internet: < http://indignacion.org.mx/wpcontent/uploads/2012/12/PuebloMayaSinDerechos.pdf $>$. 
A partir de las acciones anteriores, el 11 de abril de 2007 se publicó en el Diario Oficial del Gobierno del Estado de Yucatán el "Decreto que reforma y adiciona la Constitución Política del Estado de Yucatán en materia de Derechos y Cultura de la Etnia Maya". ${ }^{126}$ La modificación constitucional consistió en la reforma del artículo 2, primer párrafo, y en la adición de nueve párrafos; se adicionó el artículo 7 bis; se reformó el artículo 28, en su primer párrafo, se adicionó un último párrafo a la fracción I, se reformó la fracción II; se adicionaron dos párrafos al inciso a) de la fracción XV del artículo 30; y se adicionó el artículo 95 bis. En consonancia con los cambios en la constitución federal, en el artículo 2 reformado se prohíbe "toda discriminación por raza, origen étnico o nacionalidad" y se reconoce que el Estado "tiene una composición pluricultural sustentada originalmente en el pueblo maya, el cual desciende de la población que habitaba la península yucateca, al iniciarse la colonización"; se señala que "la conciencia de la identidad maya de Yucatán es el criterio fundamental para determinar que a una persona le son aplicables las disposiciones sobre el pueblo maya yucateco y sus comunidades"; se indica que "se establecerá un organismo que definirá, ejecutará y evaluará las políticas públicas que garanticen la vigencia de los derechos del pueblo maya" y que "el Estado garantizará al pueblo maya la aplicación de sus propias formas de regulación para la solución de conflictos internos”.

En el artículo 7 Bis "se reconoce el derecho a la libre determinación del pueblo maya, bajo un marco autonómico en armonía con la unidad Estatal", lo que significa que pueden decidir sobre "sus formas internas de convivencia, organización social, económica, política y cultural", en la preservación del "idioma maya peninsular, los conocimientos y todos los elementos que constituyan la cultura e identidad del pueblo maya yucateco", sobre el "uso, disfrute y aprovechamiento sustentable de los recursos naturales", la elección de autoridades y representantes, y que "los integrantes del pueblo maya serán considerados como sujetos de derecho público".

De acuerdo con el artículo 28 reformado, el informe por escrito anual del gobernador del estado "deberá contener un apartado que comprenda de manera sucinta el resumen del informe en lengua maya, en sus distintos ámbitos de competencia”.

\footnotetext{
126 "Decreto número 755. Se reforma el artículo 2, primer párrafo y se adicionan nueve párrafos; se adiciona el artículo 7 bis; se reforma el artículo 28, en su primer párrafo; se adiciona un último párrafo a la fracción I; se reforma la fracción II, se adicionan dos párrafos al inciso a) de la fracción $\mathrm{XV}$, del artículo 30 , y se adiciona el artículo 95 bis, todos de la constitución política del estado de Yucatán".
} 
En la fracción I del artículo 30 se establece que "En la creación de nuevos municipios, los integrantes de las comunidades del pueblo maya, cuya distribución territorial se vea afectada, deberán ser previamente escuchados"; en la fracción II del mismo artículo "Arreglar definitivamente los límites municipales, de conformidad con lo establecido por las leyes respectivas y las instancias técnico-normativas de la materia, tomando en consideración la opinión de las comunidades del pueblo maya, cuando resulten afectados"; y en la fracción III se indica que "la educación del pueblo maya será objeto de atención especial del Estado" y que se garantizará "la educación bilingüe e intercultural".

En el Artículo 95 Bis se señala que "El Estado garantizará, protegerá y promoverá el desarrollo social, económico, político y cultural del pueblo maya", procurando la “incorporación de las mujeres mayas al desarrollo".

Por último, en los artículos transitorios, se establece que "La ley reglamentaria en materia de Derechos y Cultura Maya deberá emitirse dentro del plazo de un año, contando a partir de la entrada en vigor del presente Decreto" y que "El organismo público, que definirá, ejecutará y evaluará las políticas de atención al pueblo maya, deberá crearse dentro del plazo de seis meses, contados a partir de la entrada en vigor del presente Decreto".

Al muy poco tiempo de ser publicada, la reforma recibió críticas de diversos sectores. Por ejemplo, la historiadora y especialista en los regímenes jurídicos de los indígenas en México, Ana Luisa Izquierdo y de la Cueva (2007), argumentó que la reforma no establecía derechos plenos, "sólo son declaraciones de buenas intenciones políticas"; del mismo modo, al igual que varios académicos y observadores del proceso, criticó que la reforma sólo se refiere a los mayas yucatecos, no contempla al pequeño número de choles ni a indígenas migrantes de otros estados de la república y de países vecinos. En palabras de Izquierdo (2007):

La reforma a la constitución de Yucatán no crea ninguna instancia específica de protección de los derechos indígenas y la garantía de su cumplimiento la reserva solo a algunos aspectos que inciden en la vida comunitaria, más bien en el ámbito de la cultura como la preservación y enriquecimiento de la lengua maya, el acceso a la educación bilingüe e intercultural y la protección de los diversos aspectos del desarrollo. Sin embargo no apunta los procedimientos e instancias para garantizarlos. 
Asimismo, el abogado y especialista en derechos humanos Geofredo Angulo López (2008:4-5) esgrimió que "la reforma, lejos de garantizar plenamente las prerrogativas de los pobladores indígenas en Yucatán, constituye en muchos sentidos un nuevo atentado contra sus derechos consignados en la Carta Magna". Si bien la "cláusula de no discriminación [...] significa uno de los avances más importantes de la reforma indígena" (2008:6), en el mismo artículo 2, el hecho de que se indique que "se establecerá un organismo...", resulta "absolutamente contrari[o] al espíritu de libre determinación en un marco constitucional de autonomía" (2008:7); aún más, "ni para la creación del Indemaya ni para su reforma se contempló en modo alguno la participación conjunta del pueblo maya" (2008:8). ${ }^{127}$

Sobre el artículo 7 bis, Angulo cuestiona que "es absolutamente omiso en cuanto a las prerrogativas contenidas en las disposiciones acabadas de transcribir [conservar y mejorar el hábitat y preservar la integridad de sus tierras]; "el legislador yucateco deberá propiciar, a la brevedad posible, una nueva reforma constitucional que tienda a reforzar al derecho fundamental de los mayas sobre su hábitat y la integridad de sus tierras" (2008:9). Otra notable omisión es la respectiva al apoyo a la nutrición de la población infantil indígena (2008:10-11).

De acuerdo con Pablo Monroy, el artículo 7 bis “es prácticamente una copia de lo dispuesto en la Constitución Federal, sin embargo se omite lo relativo a 'conservar y mejorar el hábitat y preservar la integridad de sus tierras en los términos establecidos en esa Constitución’ y para 'elegir, en los municipios con población indígena, representantes ante los ayuntamientos'. La omisión relativa a la preservación de sus tierras, obedece sin duda alguna a las reiteradas denuncias en contra de fraccionadores y acaparadores de tierras, que se valen de las condiciones de opresión en las que viven los ejidatarios para comprarlas a precios irrisorios y luego especular con ellas o dedicarlas a proyectos lucrativos" (2013:87); y "dado el alto número de municipios con población maya, la omisión relativa a que puedan elegir representantes ante los ayuntamientos, sólo puede obedecer a la determinación de evitar su paulatino empoderamiento político” (2013:88).

\footnotetext{
${ }^{127}$ Otro aspecto cuestionable, en el mismo artículo 2, es que se omite el "sexuales" de las "preferencias", al dejar sólo "preferencias", queda ambiguo.
} 
Teniendo en cuenta el carácter del proceso legislativo descrito en párrafos anteriores, no extraña que el primer documento producto del proceso enfatice los aspectos culturales de los derechos del Pueblo Maya y deje de lado los materiales, como los relativos a las tierras y los recursos naturales, así como a la autonomía. ¿Qué respuesta hubo por parte del estado a las diversas críticas a la reforma constitucional?

\section{Hacia la legislación secundaria}

Tras la reforma constitucional de 2007, en marzo de 2008 se realizaron dos foros con el objetivo de elaborar la ley secundaria: "Visión académica sobre los derechos étnicos en el estado", con asistencia de académicos de la UNAM, CIESAS, Facultad de Ciencias Antropológicas y Facultad de Economía de la UADY y del INAH, y "Problemática sobre la defensa de los derechos étnicos en el estado", en donde participaron Maya'on, el Colegio de Abogados, el Consejo de Ancianos y Sacerdotes Mayas, la Casa de la Cultura Jurídica, y académicos como Esteban Krotz, Pablo Monroy, Fidencio Briceño, entre otros. Asimismo, la Comisión Especial de Asuntos Étnicos emprendió un estudio comparativo de las diez leyes sobre derechos y cultura indígena que existen en el país e invitó al Dr. Diego Iturralde para que impartiera una conferencia sobre experiencias exitosas legislativas.

A partir de estos eventos la fracción del PRI presentó una iniciativa de ley reglamentaria el 12 de abril de 2008 y el PAN hizo lo mismo tres días después. Posteriormente, en junio de 2008 se organizaron las Mesas de análisis de las Iniciativas de Ley Reglamentaria en Materia de Derechos y Cultura Maya del Estado de Yucatán. A continuación describiré en qué consistieron las iniciativas, en qué medida retoman las demandas presentadas por los distintos actores del proceso, así como las visiones sobre el problema indígena presentes en ellas.

La Iniciativa del PAN, titulada "Ley Reglamentaria sobre Derechos y Cultura de la Etnia Maya del Estado", fue presentada el 15 de abril de 2008 por el diputado José Antonio Aragón Uicab. Se puede observar que, desde su exposición de motivos, presenta a los "integrantes de la etnia maya" como ignorantes de la ley:

¿Si para quienes entendemos algo de leyes, nos resulta difícil, en innumerables ocasiones, comprender porque [sic] se nos aplica una ley, imagínese lo que significará para aquellas 
personas integrantes de la etnia maya, quienes desconocen tanto su contenido como su aplicación por diversas razones?

La iniciativa del PAN constó de 124 artículos, divididos en cuatro títulos, con 15 capítulos y 11 artículos transitorios; propone una reforma al artículo segundo de la constitución, agregar en el párrafo tercero la palabra bilingüe, y que Yucatán reconoce como idiomas oficiales al español y al maya; presenta también una reforma al artículo 90, en donde se establece que la educación que imparte el estado será bilingüe. En gran medida, la iniciativa retomó las propuestas de los foros. En palabras de Aragón y Victor Ramírez, secretario técnico de la Comisión, la iniciativa del PAN fue muy aceptada, "porque mucho de lo que tenía la iniciativa eran las demandas que había realizado la población". 128

En el primer título, "De los pueblos y comunidades mayas", destaca el artículo 9 que establece la incorporación de un integrante de la etnia maya al Consejo de la Codhey y la creación de una Visitaduría especializada en asuntos de la etnia maya; en el capítulo segundo se establecen los derechos de autodeterminación y se les otorga a los integrantes de la etnia maya el carácter de sujetos de derecho público, las cuales fueron dos de las demandas más presentadas en los foros; el capítulo tercero abunda sobre el tema de la autonomía.

El segundo título, "De los derechos de la etnia maya”, parece responder más hacia las propuestas de algunos académicos, aunque también a algunas demandas de organizaciones indígenas. En él, se establece la obligación del estado de crear el Museo de la Cultura Maya, con dos centros de investigación (uno de historia y otro de lingüística, con investigadores de tiempo completo), la creación de un fondo para financiar estudios sobre cultura maya y fomentar las manifestaciones culturales; en el artículo 26 se establece la creación de la asignatura Lengua y Cultura Maya, que se deberá impartir en todos los grados de las escuelas de educación básica, la cual también es una de las principales demandas de las organizaciones indígenas; el capítulo tres es

${ }^{128}$ De acuerdo con los diputados de la fracción del PAN, la principal demanda en los foros fue la oficialización de la lengua, que sea reconocida por el gobierno. Esto permitiría un mayor uso de la lengua maya escrita, pues casi no se escribe", "otra de las principales demandas ha sido la educación bilingüe e intercultural", así como el "reconocimiento de la medicina tradicional". 
sobre los grupos vulnerables de la etnia maya; el cuarto sobre los servicios de salud y la medicina tradicional; el capítulo quinto sobre la tierra y recursos naturales.

El título tercero, "Del desarrollo de las comunidades y pueblos mayas", reconoce a la Asamblea comunitaria como la máxima autoridad de las comunidades mayas. El título cuarto es el relativo a "De los sistemas de justicia y la religión"; en cuanto a la justicia, se modifica el nombre de la institución Juez de paz por Juez de paz y conciliación étnica y se señala que se abrirá de oficio la segunda instancia de los juicios en que sea parte un integrante de la etnia maya, a cargo de un Magistrado con jurisdicción mixta; el Juez de paz y conciliación étnica será nombrado a propuesta de las autoridades municipales; con respecto a la religión, en el artículo 124 se establece la obligación de emitir una declaratoria de sitios y lugares sagrados y centros ceremoniales.

De acuerdo con José Antonio Aragón Uicab, presidente de la Comisión Especial de Asuntos Étnicos, después de realizar los foros, Víctor Ramírez, el secretario técnico de la Comisión, y él propusieron la idea de incluir en la ley reglamentaria la figura de los Jueces de Paz y de Conciliación Maya, ya que, según sus palabras, "estos ya existen en muchos lugares del interior del estado, sin embargo, no están reconocidos por la ley”; así, con su creación se busca "evitar la burocracia y reducir costos para la gente. Se trataba de hacer legal algo que de facto existe y funciona”. Sin embargo, estos jueces no tienen competencia en materia penal. También hay que observar que la idea de reconocer a estos jueces parte también de cierta concepción sobre los mayas de Yucatán. Según Ramírez:

En Yucatán la población indígena está muy urbanizada. No hay comunidades aisladas, como en Chiapas. [...] sus instituciones ya han cambiado mucho [...] Por esto, para elaborar la iniciativa, primero tratamos de identificar las instituciones que se considerarían en la ley. Es decir, si hay instituciones, y cómo podrían funcionar. Un ejemplo es el de los jueces de paz. ${ }^{129}$

Cuando le pregunté a Ramírez a qué se debió la tardanza en llevar a cabo la reforma constitucional, me respondió que por falta de compromiso; que el anterior presidente de la Comisión, Mario Peniche, "no estaba capacitado, no conocía los problemas". Menciona que también antes el tema no era importante, y que ahora (2008-2009), "es un

\footnotetext{
${ }^{129}$ Aquí cabe agregar que por "autonomía” entienden la "integración de las comunidades indígenas al país,
} no su aislamiento". 
verdadero boom", aparece frecuentemente en los periódicos, "ahora los medios de comunicación tienen un mayor interés en el tema". ${ }^{130}$ Sin embargo, y a pesar de las diversas críticas realizadas a la reforma constitucional, tanto los diputados del PAN como los del PRI continuaron concibiendo el tema en términos culturalistas: de lo que se trataba era de reconocer y revalorar la cultura de los mayas.

Por su parte, la fracción del PRI presentó la iniciativa "Ley Reglamentaria en Materia de Derechos y Cultura Maya del Estado de Yucatán". Hasta la fecha, no he tenido acceso a este documento.

Por otra lado, Maya'on cuestionó la poca concurrencia que tuvieron las reuniones organizadas por Indemaya y la Comisión, de modo que en marzo de 2008 convocó a un foro de consulta, que se llevó a cabo en las instalaciones de Indemaya y al cual asistieron 52 personas. Las propuestas que resultaron del foro fueron entregadas al congreso del estado. El 20 de junio de ese mismo año Maya'on convocó a otro foro, esta vez en Valladolid, en las instalaciones de la Universidad de Oriente, al cual asistieron 155 personas. Las mesas de trabajo del congreso del estado para el análisis de la iniciativa de ley comenzaron unos días después, el 22 de junio, y en ellas fueron leídas las propuestas de Valladolid. ${ }^{131}$

Por parte de los académicos, después de haber sido aprobada y publicada la reforma constitucional, en el proceso de legislación reglamentaria, Krotz propuso "revisiones profundas de la legislación vigente con respecto a la estructura de autoridad" en tres ámbitos: el código de procedimientos penales y la ley orgánica del poder judicial para permitir e incluso fomentar la existencia de juzgados locales basados en usos y costumbres mayas; el código de procedimientos electorales y la legislación municipal; la planeación, ejecución y evaluación del desarrollo a nivel estatal y municipal, para garantizar la participación de la población maya (2008:10); realizar un "inventario sistemático del código genético y la investigación igualmente sistemática y sostenida de posibilidades de las especies vegetales y animales regionales de uso alimenticio y terapéutico y la difusión de este conocimiento en la Península" (2008:11); dedicar montos presupuestales significativos sobre el tema del cambio climático; investigación y

\footnotetext{
${ }^{130}$ Entrevista a José Antonio Aragón y a Victor Ramírez, Recinto del Poder Legislativo, Mérida, Yuc., 30 de enero de 2009.

${ }^{131}$ Entrevista con B. Alonzo, 2009.
} 
promoción de la energía solar y de la energía eólica (2008:11); la revisión de la legislación referente al régimen impositivo, conceder incentivos fiscales para dos tipos de actividades: empresas sociales mayas y pequeñas empresas mayas; para la creación y alimentación continua de fundaciones y asociaciones sin fines de lucro destinadas a apoyar actividades económicas, educativas y artísticas de la población maya y de su difusión en la sociedad no maya (2008:11-12); el desarrollo de todos los ámbitos de la creación artística, la creación de un Instituto de Estudios Mayas (2008:12), así como de un Museo de la Cultura Maya, ligado con el instituto (2008:13).

Asimismo, Pablo Monroy cuestionó que se hablara de jueces de paz, los cuales son elegidos por los presidentes municipales y controlados por el Tribunal, y propuso que se empleara el concepto de jueces del pueblo maya, ya que, según su opinión, "ellos deben tener sus propios jueces". Así, propuso que los pueblos originarios elijan a sus propios jueces y que trabajen en colaboración con el estado, no que sean elegidos por el Tribunal Superior.

Sin embargo, después de ser presentadas y discutidas las iniciativas, hubo un nuevo desacato, y las actividades fueron retomadas hasta 2011 con la LIX legislatura. Cuando le pregunté a Bartolomé Alonzo qué pensaba sobre el estancamiento del proceso legislativo, me comentó:

A los políticos de Yucatán no les gusta mucho los discursos mayas, cuando hablan del pueblo maya es por la constitución, pero no hay ningún interés por los mayas, no hay líder que lo asuma, en la campaña actual tampoco hubo interés. Por eso la ley está estancada, no hay ningún Felipe Carrillo Puerto. Pero la sociedad en general está tomando conciencia de que lo maya debe resurgir, puede que en el futuro haya clases políticas que asuman el tema, podría pasar como el caso de Bolivia y Evo Morales.

Los políticos nos tienen bien ubicados, y nos entienden. $\mathrm{Y}$ se asustan un poco. Si en Yucatán la mitad de la población es maya, lo justo es que la mitad del congreso sean mayas, pero esto no les gusta a los políticos. La iniciativa de ley de derechos y cultura maya se pospone no porque falte algo, sino porque implica un paso muy fuerte para que el pueblo maya alcance cosas. Pienso que los diputados tienen clara conciencia de esto, y posponen la ley, para que no se toquen sus privilegios. Cuando se habla de la oficialización de la lengua maya, implica que todas las instituciones públicas tienen la obligación de atender al pueblo maya en su propia lengua. La Ley General de Derechos Lingüísticos de los Pueblos 
Indígenas lo respalda, ya que establece que todas las lenguas indígenas son lenguas nacionales. La oficialización implicaría que todo fuera en los dos idiomas. Creo que las próximas generaciones mayas se darán cuenta de su identidad, de su historia, lo que llevará a una conciencia colectiva, que va a transformar las estructuras sociales.

Las actividades en materia de legislación fueron retomadas a inicios de 2011. A mediados de enero se constituyó la Comisión Permanente para el Respeto y Preservación de la Cultura Maya, que reemplazó a la Comisión Especial de Asuntos Étnicos, y el 26 de enero de 2011, las fracciones del PRI y del Partido Verde presentaron la "Iniciativa de Ley para la Protección de los Derechos de la Comunidad Maya del Estado de Yucatán”, cuyo objeto es "garantizar a la comunidad maya de Yucatán el acceso a la justicia basada en sus propias tradiciones"; proponen la creación de la autoridad "Juez maya", nombrada por la "Comunidad maya"; también destacan la creación de un Registro Estatal de Comunidades Mayas en el Estado de Yucatán. La iniciativa de ley está estructurada en cinco títulos, 32 artículos y 4 artículos transitorios; "Disposiciones generales", "Atribuciones de las autoridades", "Del Instituto para el Desarrollo de la Cultura Maya del Estado de Yucatán”, quien estará a cargo del Registro Estatal; "Desarrollo de las comunidades mayas" y "De la Justicia Maya".

Para dar a conocer y discutir la iniciativa de ley se organizaron tres Foros de Consulta sobre los Derechos y Cultura de la Etnia Maya, celebrados en los municipios de Chemax, Ticul y Mérida. Sobre estos foros, la antropóloga Ana Rosa Duarte (20132014:266-267) ha escrito que:

En Yucatán se realizaron tres "consultas" a marchas forzadas durante las últimas semanas del plazo de aprobación. Las pocas personas que asistieron a dichas consultas fueron invitadas y les organizaron el viaje. Así lo pude constatar el segundo día de consulta, en el sur de Estado, donde participé como especialista en los estudios de la cultura maya. En la Sala se habían reunido aproximadamente 150 personas de los pueblos cercanos, acompañados por funcionarios. Una vez cumplido el protocolo, a los asistentes de las poblaciones les entregaron cuatro tacos de cochinita pibil, acompañados de una bolsa de jugo, mientras que los funcionarios e invitados especiales se fueron a un almuerzo en un conocido restaurante de la misma población. De acuerdo con otro compañero del equipo de investigación, en la primera consulta llevada a cabo en el oriente del Estado asistieron 
aproximadamente 200 personas de diferentes poblaciones, movilizadas por los funcionarios municipales y locales. La tercera reunión se llevó a cabo en la ciudad de Mérida, con una asistencia de aproximadamente 300 personas, trasladadas de la misma manera que las anteriores.

Por lo demás, la iniciativa fue sumamente criticada, especialmente por versar prácticamente sólo sobre el tema de justicia. A esta nueva versión del estado respondieron algunas organizaciones mayas y otros organismos de la sociedad civil. Así, en la sesión del 30 de marzo en Mérida, ${ }^{132}$ la cual comenzó con un ritual celebrado por sacerdotes mayas, entre ellos Don Valerio Canché, presidente del Consejo de Ancianos y Sacerdotes Mayas, durante la sesión de intervenciones, el profesor Bartolomé Alonzo, en representación de la Comisión de Derechos Humanos, entregó a los diputados un documento de 45 páginas titulado "Propuestas para considerar en la ley sobre los derechos y cultura de la etnia maya", del cual enfatizó algunos aspectos: que la ley garantice la asignación de recursos de manera estructural, que tenga una orientación integral y transversal, que se cree la Secretaría para el Pueblo Maya que unifique el trabajo de las diversas instituciones. La propuesta fue elaborada por la Coordinadora del Colectivo Derechos del Pueblo Maya, en la cual participan Maya'on, la Comisión de Derechos Humanos y otras organizaciones. A continuación describiré con más detalle la propuesta de la Coordinadora, pues me interesa destacar las coincidencias y diferencias con la iniciativa de ley del PRI/PVEM y la ley resultante. Sus primeros planteamientos son que "se debe considerar a los integrantes del Pueblo Maya como sujetos de derecho público"; solicitaron ampliar la consulta para la ley en los 106 municipios del estado y con la "participación activa de los integrantes del Pueblo Maya"; así como la creación de una "Secretaría del Pueblo Maya". Estos primeros planteamientos fueron firmados por Baltazar Xool May, representante de la CODHEY en la Comisión Coordinadora del Colectivo Derechos del Pueblo Maya, y Bartolomé Alonzo Caamal, representante de las organizaciones de la sociedad civil en la Comisión Coordinadora del Colectivo Derechos del Pueblo Maya.

El primer apartado de la propuesta de ley es sobre la "Vigencia de derechos y

132 En la mesa panel participaron Fidencio Briceño, Pablo Monroy, Valerio Caché, Adolfo Iván (Universidad de Oriente) y el antropólogo Alberto Barceló. 
autonomía", a la cual señalan como "un derecho propio de cada pueblo", junto al "derecho al ejercicio de la Libre Determinación". En este primer apartado la Coordinadora demanda reconocer en la legislación los "Derechos Autonómicos que tiene el pueblo maya" y reconocen que la autonomía no pone en cuestión la soberanía nacional, uno de los temores recurrentes en diversos sectores de la población cuando se habla del tema. Como parte de la autonomía se demanda el reconocimiento de la libre elección de las propias autoridades, como el Juez de Paz, el Comisario Municipal, el Comisario Ejidal, entre otras; el derecho a la organización social y política de acuerdo a los sistemas normativos propios; a formar asociaciones que se consideren convenientes; y, por último, que en materia de conflictos agrarios se cree una "instancia de Conciliación Agraria del Estado".

El segundo tópico de la propuesta de ley es la "Educación intercultural y bilingüe". En la propuesta los autores observan que el artículo 11 de la Ley de Educación del Estado de Yucatán establece que el estado "garantizará que la población indígena tenga a la educación básica bilingüe cultural e intercultural" y, al respecto, señalan que dicha ley tiene alcances muy limitados, y que la educación que se imparte de facto en las escuelas oficiales "se ha caracterizado por favorecer la enseñanza del castellano y del inglés y por excluir a la lengua maya". Por ello, demandan que "la nueva ley debe poner fin a estas políticas educativas que vulneran la identidad lingüística y cultural de los educandos de origen maya". Así, en este apartado se exige que la educación intercultural y bilingüe sea obligatoria en todos los niveles educativos en el estado; se pide la creación del "instituto de la lengua maya del estado de Yucatán”, el cual debe encargarse de dar cumplimiento a la Ley General de Derechos Lingüísticos de los Pueblos Indígenas, así como una "universidad maya para los mayas", "crear bibliotecas mayas", "rescatar los códices mayas que se encuentran en otros países" e "institucionalizar la enseñanza de la numerología maya".

El tercer apartado de la propuesta concierne al problema de la "Migración" y se propone "incorporar en la ley sobre Derechos y Cultura Maya, los derechos humanos de los migrantes", entre ellos la prohibición de cualquier forma de discriminación a la población migrante, la formulación de políticas públicas para proteger a los migrantes así como "el fortalecimiento de nuestras tradiciones culturales, costumbres y el desarrollo de la cultura maya evitando la pérdida de valores se propone insertar en la ley el reconocimiento de la importancia de la interculturalidad". 
El cuarto tema de la propuesta de ley es el de "Infraestructura comunitaria y urbana", con respecto al cual se exige que la ley de "la oportunidad a la población indígena de proponer políticas públicas, programas, estrategias y acciones para el bienestar individual y colectivo", que exista transparencia sobre los recursos, el desarrollo de un proyecto integral de comunicación y difusión "para el fortalecimiento y reivindicación de la identidad indígena", que la CDI promueva la participación de las dependencias de los tres órdenes de gobierno para la planeación, construcción y el mejoramiento de la infraestructura básica con una visión integral e intercultural y con criterios de sustentabilidad y respeto al entorno del medio ambiente.

El "Medio ambiente y recursos naturales" constituye el quinto apartado de la propuesta de ley, en donde se demanda que "el pueblo maya debe ser propietario y tener la soberanía de su territorio" y que "el pueblo maya debe diseñar e implementar en conjunto con el gobierno del estado, el desarrollo del estado". Se exige también el acceso a los recursos naturales de las tierras y territorios indígenas, la conservación del medio ambiente y la protección de los recursos naturales, no sólo por parte del Estado, sino también de los pueblos y comunidades indígenas "conforme a sus sistemas normativos internos"; que todas las obras y proyectos que promueva el Estado, las organizaciones o los particulares que impacten a los pueblos y comunidades indígenas en sus recursos naturales sean discutidos, analizados y consensados previamente con dichos pueblos y comunidades; por último, plantean "el derecho a exigir la reparación del daño ecológico correspondiente a la fuente emisora, previo dictamen de la SEDUMA o de las autoridades federales componentes".

El sexto apartado está dedicado a la "Participación del pueblo maya en la vida política del país" y se propone incentivar la participación política de los representantes de los pueblos mayas en las instancias de decisión estatal y municipal; que la administración pública "escuche y considere la opinión de los pueblos y organizaciones mayas del estado"; que la población maya esté representada en las instancias de administración pública; promover la constitución de asociaciones mayas con personalidad jurídica para asegurar su participación, entre ellas educacionales y culturales, profesionales y económicas.

La séptima sección es sobre la "Participación del pueblo maya en los medios de comunicación", en la cual se exige que el Congreso tome en cuenta la normatividad 
internacional en materia del derecho a la libertad de expresión y los derechos de los pueblos indígenas; legislar sobre el derecho de las comunidades y pueblos mayas a la propiedad, manejo y operación de sus propios medios de comunicación; que la legislación en materia de radio, televisión y telecomunicaciones establezca criterios claros y equitativos, basados en elementos sociales y no sólo económicos o técnicos; que se garantice el acceso de pueblos y comunidades indígenas a la administración y operación de frecuencias radioeléctricas y medios de comunicación; el reconocimiento, protección y respeto a la autonomía de los medios comunitarios y que el Estado esté obligado a financiarlos y desarrollarlos; que se reconozcan vías que les permitan a los medios comunitarios realizar actividades económicas sin fines de lucro; que se establezca un mínimo del 7\% del espacio aire para publicidad o patrocinios a los medios comunitarios; que se permita la transmisión en lengua maya y que se abran espacios para programas mayas en los tiempos oficiales; que se cree un fideicomiso que apoye financieramente el desarrollo de las radio comunitarias; que se incorpore una cuota del $50 \%$ de personas indígenas en puestos como locutores, artistas, expertos, comunicadores, técnicos y administrativos en los medios de comunicación estatales y privados; que las futuras reformas que afecten directa o indirectamente a los pueblos y comunidades indígenas sean consultadas debidamente con los sectores involucrados; fomentar la existencia de corresponsales y comunicadores comunitarios; e incentivar el uso de nuevas tecnologías para la comunicación en las comunidades indígenas.

El octavo apartado está dedicado al tema de "Cultura maya", en el que se propone "crear el instituto de la cultura maya que se dedique a la investigación, registro y difusión de todos los ámbitos de la cultura maya y evitar el folklorismo existente y persistente en la actualidad"; la creación de "una universidad en donde se forme a la población maya"; integrar en los planes y programas de la educación en el estado los resultados de la investigación de la cultura maya; crear la infraestructura para que participen los tres órdenes de gobierno en todos los municipios del estado; y asegurar el recurso financiero para la investigación, formación y difusión de la cultura maya.

El "Desarrollo económico equitativo y sustentable" es el tema del noveno apartado. En él se aborda el patrimonio físico de los territorios y tierras comunales; el manejo abierto y transparente de los recursos; buscar equipos que complementen funciones económicas; 
elegir la figura legal más adecuada para las asociaciones; la búsqueda de apoyo técnico y asesoría en factores claves de producción; que las asociaciones tengan "sostenibilidad" a mediano y largo plazo; por último, proponen un “espíritu emprendedor”.

El último apartado de la propuesta de ley está dedicado al tema de "Tierras y territorios". En él se exige elevar a nivel constitucional del estado de Yucatán y del país diversos artículos del Convenio 169 de la OIT relativos a tierras y territorios (artículo 2, fracc. 1; artículo 13, fracciones 1 y 2; artículo 14, fracción 1; artículos 15, 16 y 17). Del mismo modo, se hace referencia al informe "Derechos de los Pueblos Indígenas y Tribales sobre sus Tierras Ancestrales y Recursos Naturales: Normas y Jurisprudencia del Sistema Interamericano de Derechos Humanos" elaborado por la Comisión Interamericana de Derechos Humanos de la Organización de Estados Americanos, en donde se argumenta que la protección de tierras y territorios no sólo es una cuestión económica, sino también de supervivencia, de cosmovisión, de derechos humanos, vida física, cultural y espiritual.

Por último, firman quienes realizaron estas propuestas: Profr. Bartolomé Alonzo Caamal, Sacerdote Maya Valerio Canché Yah, C. Baltazar Xool May, C. Próspero Serrano Sánchez, Profr. Jaime Novelo González, Profr. Juan Damaceno Sulub y Maya, C. Baldomero Ku Ceh, Profr. Pedro César Jiménez Peraza, C. Jesús Solís Alpuche, C. José Honorio Cemé Euán, C. Jorge Coronado Arceo, Lic. Mireya Zapata Amaya, Lic. Alejandra Carranza Avila; las asociaciones civiles. Maya’on A.C., Kuch Kaab Yeetel J-Men Maya’ob A.C. (Sacerdotes y Ancianos Mayas), Kuxa'ano'onm A.C., Chan Tzab Can A.C., Maya A.C. y la Comisión de Derechos Humanos del Estado de Yucatán.

Al terminar el foro, uno de los investigadores asistentes me comentó que la iniciativa que presentó la actual comisión del Congreso del Estado le pareció terrible; que la había comentado con otros colegas y dijeron que no podían aprobar esa iniciativa como ley; también señaló que hubo resistencia por parte de la Comisión a que los foros se hicieran públicos, aunque, como ya se ha apuntado arriba, finalmente se hicieron tres, uno en Chemax, otro en Ticul, y el de Mérida. Con todo, fue básicamente esta iniciativa la que se convirtió en la "Ley para la protección de los derechos de la comunidad maya del estado de Yucatán”, dejando de lado la mayoría de las propuestas de organizaciones y académicos. 
La "Ley para la protección de los derechos de la comunidad maya del estado de Yucatán"

La "Ley para la protección de los derechos de la comunidad maya del estado de Yucatán" fue aprobada por unanimidad por el pleno del Congreso del Estado, fue publicada el 3 de mayo de 2011 en el Diario Oficial del Gobierno del Estado de Yucatán y entró en vigor el 1 de enero de 2012; el reglamento de la misma fue publicado el 30 de diciembre de 2011. De acuerdo con un comunicado de la fracción parlamentaria del PAN a propósito de la aprobación de la ley en el Congreso del Estado, "la preservación de la cultura, la no discriminación, igualdad, solidaridad y armonía social son los principios rectores de la Ley para la protección de los derechos de la comunidad maya del estado de Yucatán". ${ }^{133}$ ¿En qué consiste la ley? Lo primero que hay que destacar es que está centrada en el tema de la "Justicia Maya". Consta de 5 títulos, 32 artículos y 6 artículos transitorios.

En el Título primero, "Disposiciones generales", se establece que la ley tiene por objeto: "Reconocer la aplicación de las propias formas de solución de conflictos internos que realice la Comunidad Maya, siempre que no contravengan lo establecido en las leyes federales y estatales" y "Establecer las bases para garantizar a los indígenas mayas del Estado sus derechos, así como el acceso a la justicia, en igualdad de condiciones que las personas no indígenas, de acuerdo a las bases establecidas en la Constitución Política de los Estados Unidos Mexicanos y la particular del Estado", con lo que queda claro que la ley versa fundamentalmente sobre el tema de la justicia y solución de conflictos. Del mismo modo, se puede apreciar que ya no hablan de "etnia maya", mucho menos de "pueblo maya", sino de "Comunidad Maya", la cual es definida como "el conjunto de indígenas que comparten las tradiciones, usos y costumbres propias de la Cultura Maya".

La Ley repara en la ausencia de otros indígenas en la Reforma, pues en su artículo 6 señala que "Los indígenas procedentes de otras comunidades que transiten o residan en el territorio del Estado, pueden acogerse a los beneficios de esta Ley y su Reglamento". Asimismo, el artículo 11 establece que "los principios rectores para la protección de los derechos de las personas de las comunidades mayas, [son] los siguientes: 1.- Preservación

\footnotetext{
133 "Aprueban la ley indígena en Congreso del Estado. Comunicado de la fracción parlamentaria del PAN".

En: Diario de Yucatán, 12 de abril de 2011. Disponible en línea: $<$ http://www.yucatan.com.mx/20110412/nota-9/104634-aprueban-la-ley-indigena-en-congreso-delestado.htm>
} 
de la Cultura Maya; II.- No discriminación; III.- Igualdad; IV.- Solidaridad, y; V.Armonía social"; es decir, no se retoman los principios interculturalidad, de autonomía y libre determinación.

El título segundo es sobre las "Atribuciones de las autoridades estatales y municipales"; a diferencia de la obligación de "garantizar" el acceso de las comunidades mayas a la enseñanza de la cultura maya, a los programas de salud, a la participación de mujeres en programas productivos comunitarios, al acceso y difusión en los medios de comunicación del estado, que se respete la normatividad internacional y nacional en materia de libertad de expresión y de los derechos de los indígenas mayas, la protección de los derechos de los niños, niñas y adolescentes, tanto el ejecutivo estatal como los ayuntamientos no "garantizan", sino deben "promover" "el rescate y conservación de la Lengua Maya"; lo mismo sucede con la medicina tradicional maya.

El título tercero es sobre el "Instituto para el Desarrollo de la Cultura Maya del Estado de Yucatán". Ahora, el Indemaya no sólo será el responsable de "identificar y analizar las necesidades, problemática y propuestas de las comunidades mayas a través de un diagnóstico integral de las mismas", sino que también deberá "elaborar y mantener actualizado el Registro Estatal de Comunidades Mayas de Yucatán”, el cual, de acuerdo con la ley, "tiene por objeto que las autoridades estatales, municipales y, en su caso, las federales, cuenten con la información necesaria de las comunidades mayas del Estado, para instrumentar la elaboración y ejecución de los programas de corto, mediano y largo plazos establecidos en esta Ley y su Reglamento". Asimismo, de acuerdo con la ley, serán los jueces mayas quienes deberán "comunicar al Instituto" la "información correspondiente de las comunidades que se encuentren dentro de su ámbito territorial de competencia".

El título cuarto está dedicado al "Desarrollo de las comunidades", que contempla como derechos los siguientes rubros: servicios de salud, educación y cultura, desarrollo comunitario, asistencia social, bienestar social, equidad y género, acceso a la justicia y "los demás que se relacionen con preservación de la Cultura Maya". Es decir, en un solo título quedan muchos de los temas que, de acuerdo con propuestas de organizaciones, académicos e, incluso, iniciativas de ley anteriores, debían merecer títulos particulares. 
Por último, el título quinto versa sobre el tema de la "Justicia Maya", la cual "será impartida por los Jueces Mayas designados por la Comunidad Maya" y que "sólo tendrán competencia en el ámbito territorial de la Comunidad Maya que los designó”. En la ley se definen también los requisitos para ser juez maya. La autonomía es mencionada únicamente en el artículo 28, en relación a la designación de los jueces mayas por parte de las comunidades mayas.

Sobre la concentración de la ley en el tema de justicia, Tito Sánchez, diputado del PAN e integrante de la Comisión, me comentó que la fracción de su partido proponía todo un capítulo de derecho a la salud, de derecho a la educación, derechos de las mujeres mayas, un capítulo de medicina tradicional maya; mencionó que, aunque lo anterior no se logró, sí se incluyeron algunos aspectos. ${ }^{134}$ Sin embargo, también comentó que estaban de acuerdo con la propuesta en general. En sus propias palabras: "es propuesta de ellos [del PRI], pero emPANizada". Otros aspectos que se propusieron en los foros y que no se incluyeron en la ley fueron, por ejemplo, que en cada ventanilla de atención al público haya al menos una persona que domine la lengua maya, escrita y hablada. Del mismo modo, Pablo Monroy propuso la creación de un magistrado mixto que atendiera asuntos que provinieran de un juez maya, pero se consideró que no se podía incluir de momento.

Al igual que la iniciativa del PRI/PVEM, la ley recibió numerosas críticas entre los actores involucrados en el proceso. El día que fue aprobada platicaba sobre el tema con una profesora de lengua maya, quien me comentó: “de nada va a servir la ley, me parece ridículo lo de los jueces mayas, pues no pueden actuar en muchas materias, sólo para delitos menores". ${ }^{135}$ A partir de algunos testimonios obtenidos en entrevistas,

\footnotetext{
${ }^{134}$ Llama la atención que, según Tito Sánchez, entre la iniciativa presentada por el PAN en 2008 y la del PRI en 2011 no hay diferencias sustanciales, la cual "va muy dirigida a la cuestión de la impartición de justicia, y realmente en diferentes aspectos ya se está contemplando dentro de [...] la nueva forma procedimental, con juicios orales".

${ }^{135} \mathrm{Y}$ esa misma noche registré algunos comentarios en Facebook sobre la noticia de la aprobación de la ley. A continuación reproduzco una conversación entre dos estudiantes, una de ellas maya hablante . Estudiante 1. "Pff esa ley es una basura, es una ofensa!!!! Porque siguan pensando con ese paternalismo tan arraigado, me hacen sentir como si yo no pudiera elegir que es lo mejor para mi. Es basura!!!!!!!!!" [Facebook, 12 de abril a las 22:24]. Estudiante 2. "Oh!, el paternalismo es algo taaaaan arraigado pero, al menos la existencia de esa ley puede ser entendida como un pasito que lleve al reconocimiento y valorización de la diversidad! :D (No te enojes)" [12 de abril a las 22:47 ]. Estudiante 1.: "Pff, es una basura, no tiene ningun solo sentido, la figura del juez maya, no tiene sentido, jamas ha existido nada como eso, es llamarle juez maya a un personaje que no tendra una funcion distinta a la del juez de paz pff, es dificil de entender para ti tal vez, lo triste es que ellos quieren que pensemos lo que tu estas pensando ahora. Pero la realidad es otra...." [12 de abril a las 23:42].
} 
podríamos considerar que la reforma y la ley resultantes fueron intentos de procesos de reajuste de solucionar el conflicto en torno a los derechos del pueblo maya. En una entrevista realizada por el autor de este trabajo, el escritor y promotor cultural Feliciano Sánchez narra así el proceso:

había un movimiento a nivel nacional por el reconocimiento de los derechos de los pueblos originarios. Curiosamente en Yucatán, en Yucatán no aparecía el pueblo maya en la constitución. Entonces en el 2005 se hace una consulta para sustentar precisamente la reforma constitucional que pudiera derivar finalmente en el reconocimiento del pueblo maya en la constitución política del estado. Con miras de que, había ya elaborada una política pública de atención al pueblo maya y si lográbamos el reconocimiento del pueblo maya en la constitución, podría derivar todo eso en una reforma institucional que, aunque no se llamara administración pública bilingüe, pudiera haber una serie de cambios en las instituciones que pudieran atender de manera más pertinente al pueblo maya. Desafortunadamente, a pesar de que el mismo 2005 se entrega esta propuesta que se hizo para el reconocimiento del pueblo maya en la constitución, la reforma no se llevó a cabo sino hasta el 11 de abril de 2007, cuando ya estaba a punto de salir el, de terminarse la administración. Entonces..., y ya no dio tiempo para más. Cuando hay, ese año 2007, hay un cambio nuevamente de gobierno, entonces en el Congreso del estado también cambian los legisladores y [en 2011] se crea una ley secundaria de reconocimiento de los derechos del pueblo maya que es una caricatura de lo que pudiera significar el reconocimiento de los derechos ¿no? Y en algún momento ya habíamos entendido que este famoso asunto del reconocimiento constitucional de los derechos de los pueblos, no venía a ser otra cosa más que ganar tiempo, ¿no?, era una forma de decir "mira oye qué me reclamas si estás en la constitución ¿no?”, "sí estoy en la constitución pero no estoy en los hechos de gobierno, no estoy en las acciones de gobierno de la forma como se planteaba”. Entonces este famoso asunto que empezó, decía, desde fines de los setenta y se empezó a tener mucho auge en los ochentas, que vino a dar resultado en Yucatán hasta el 2007 con la reforma constitucional, no era más que una forma de ir ganándole tiempo al asunto. Lo vemos con los constantes cambios, no sé, en educación indígena misma, que aún no define una buena plataforma para fortalecer ni la lengua maya ni la identidad del pueblo maya, entonces, hay como que una muy fuerte resistencia de los gobiernos, de los distintos gobiernos, niveles y órganos del gobierno para que, efectivamente, haya una buena política propicia para el desarrollo de los pueblos originarios. Entonces lo que en su momento pareciera ser interesante, de repente comienza a derivar con que, hace cuenta 
Culturas Populares se estanca en su presupuesto; el INI, supuestamente por un desgaste institucional, se planteó originalmente para que efectivamente sea una instancia, como se intentó con Indemaya también, que sea una instancia diseñada y operada por los pueblos originarios ¿no? El INI terminó solamente cambiando su nombre y cambiando algunos programas y se convirtió en CDI. El Indemaya después del 2007, y con la ley reglamentaria que sacaron, el Indemaya se ratifica como una instancia del gobierno totalmente diferente a lo que decía la reforma constitucional que se publicó en abril de 2007, que como decía debía ser una instancia diseñada y operada por el pueblo maya para una efectiva interlocución con el gobierno. Entonces no ha habido grandes cambios, hay acciones, no podemos negar que no se esté realizando nada, sí hay cosas que se están haciendo pero es como hacer algo para retrasar, retrasar y posponer y posponer y posponer esta posibilidad efectiva de plantear programas serios para el desarrollo de los pueblos originarios incluido el pueblo maya.

Por su parte, Freddy Poot, del Movimiento Indígena Nacional, me comentó que:

Se hizo la ley de manera horrible, le dicen la "ley Montejo", de la Conquista. Un nombre horrible, Ley para la Protección de los Derechos de las Comunidades Mayas de Yucatán; en la ley se contraviene el espíritu de la reforma, hay cosas inadmisibles. Faculta al Indemaya, que es una dependencia del gobierno estatal, de tipo asistencial, lo faculta para que resuelva quiénes son los mayas y comunidades mayas para ver quiénes son beneficiarios. En cambio, el Convenio 169 [de la OIT] habla de la autoadscripción.

Del mismo modo, según la antropóloga Ana Rosa Duarte, "uno de los supuestos en que descansa la recién aprobada Ley para la Protección de los Derechos de la Comunidad Maya del Estado de Yucatán" (2013-2014:258) es la idea de que "no pasa nada" en el mundo maya peninsular, la "representación de los mayas peninsulares como pasivos y sin interés en conocer sus propios derechos" (2013-2014:258). En entrevistas que ha realizado con jóvenes mayas sobre el tema de autonomía,

todas coinciden al expresar sus preocupaciones acerca de los derechos a la libre determinación, al ejercicio de su autonomía y al disfrute del territorio — derechos que no están considerados en la actual Ley Maya-. Esta ley, además de ignorar todos estos reclamos y recomendaciones del pueblo maya y las organizaciones internacionales, se limita a crear una figura jurídica "opcional" del "Juez Maya” para la resolución de 
conflictos internos, a redefinir al pueblo maya yucateco como "las minorías mayas" y declarar que son "más bien mestizos" [...] en lugar de garantizar los derechos del pueblo maya a la libre determinación, autonomía y territorio, la Ley Maya entrega la 'comunidad maya' al Instituto para el Desarrollo de la Cultura Maya del Estado de Yucatán (INDEMAYA) para su administración, preservación y desarrollo (2013-2014:268).

Así, una de las conclusiones es que esta nueva ley es "simplemente un mecanismo más del neocolonialismo": "por un lado, no garantiza la libertad de los pueblos mayas para decidir sus formas internas de convivencia, organización social, económica, política y cultural, tal como está estipulado en la Constitución nacional. Por otro lado, corre el riesgo de consagrar, tanto el cliché del mestizaje en general, como el esquema del 'mestizo' que se ha vuelto una masa nacional que oculta a los indígenas" (20132014:269).

Podemos apreciar que Sánchez, Poot y Duarte coinciden en que quien salió beneficiado de la ley fue el Indemaya o, en otras palabras, el Estado. Retomando los estudios de Magdalena Gómez (2013), podemos sostener que los derechos indígenas se subordinaron a la "razón de Estado" en Yucatán.

Pablo Monroy (2013) ha ofrecido una visión crítica pero no de total rechazo de la ley y ha argumentado que existe en ella una retórica de derechos humanos, aunque es necesario que los mayeros se reconstituyan como sujetos sociales y transformen esa retórica en "derechos en acción". Si bien tiene en cuenta las limitaciones de las reformas constitucionales a nivel federal y estatal, se adscribe a la postura de "hacerla[s] efectiva[s] [...] ya que propicia la exigibilidad y justiciabilidad de importantes derechos fundamentales y el diseño de políticas públicas con la participación indígena y prevé las partidas presupuestales necesarias para su ejecución” (Monroy 2013:82-83). Así, para Monroy, "un proyecto que podría coadyuvar en dicha empresa [la reconstitución de los mayeros como sujetos sociales], es la revitalización de su sistema normativo por conducto de la judicatura maya. Se trata de un programa que la Ley para la Protección de los Derechos de la Comunidad Maya del Estado de Yucatán encomienda al Instituto para el Desarrollo de la Cultura Maya en Yucatán” (Monroy 2013:140). 
Asimismo, Monroy reconoce un acierto en que la ley establezca que los jueces mayas sean elegidos por las propias comunidades (como vimos, fue una de las principales críticas que hizo a las iniciativas anteriores). En sus palabras:

Ciertamente la ley no recogió todas las sugerencias formuladas por las organizaciones mayas y 'expertos' que comparecimos a las diversas consultas que los legisladores llevaron al cabo, pero uno de sus aciertos es que respetó el derecho de los mayas a la autodeterminación en un marco de autonomía, pues existía en las deliberaciones del proyecto de ley la intención de sujetarlos al Poder Judicial del Estado, lo que hubiera contravenido flagrantemente la autonomía constitucional de que goza el pueblo maya tanto en la Constitución federal como en la estatal (Monroy 2013:140).

\section{Después de la ley}

Después de ser aprobada y publicada la ley, la Comisión Permanente para el Respeto y Preservación de la Cultura Maya, junto a la de Desarrollo Económico y Fomento al Empleo, presentaron el 17 de febrero de 2011 la iniciativa de decreto por la que se declara al "2012 Año de la Cultura Maya". De acuerdo con Tito Sánchez, después de la ley, lo que sigue es lograr que 2012 sea considerado año de la cultura maya, que "esto nos reporte beneficios económicos"136. En el decreto se refieren a la "Cultura Maya" antigua, al "legado de nuestros ancestros mayas", a la "inteligencia de esta civilización y su notable avance científico", a que "nuestros ancestros mayas sobresalieron por su calendario", a que "la actividad arquitectónica de la civilización maya continúa recordándonos su increíble grandeza”. En el próximo capítulo de la tesis veremos cómo diversos actores impugnan esta visión gubernamental sobre la cultura maya.

Cuando el 25 de junio de 2013 fueron nombrados nueve nuevos jueces de paz, 82 municipios de Yucatán ya contaban con dicha autoridad. Cabe aclarar que las atribuciones de los jueces de paz han cambiado desde las reformas en materia de derechos humanos tras las modificaciones del artículo 1 constitucional en $2011 .{ }^{137}$ Los primeros siete jueces mayas elegidos por las comunidades del estado fueron nombrados el 7 de diciembre de 2013. El Indemaya y el Tribunal Superior de Justicia del estado de

\footnotetext{
${ }^{136}$ Entrevista con Tito Sánchez Camargo, H. Congreso del Estado de Yucatán, Mérida, Yuc., 8 de abril de 2011.

${ }^{137}$ Tomado de: $<$ http://www.tsjyuc.gob.mx/?page=iblog\&n=303>.
} 
Quintana Roo otorgaron los títulos como jueces de paz. El secretario general de gobierno de Yucatán, Víctor Caballero Durán, declaró: “Gracias a su esfuerzo y dedicación ustedes pasarán a la historia como los primeros jueces mayas, porque en Yucatán no basta con tener más policías si no es necesario entender la justicia y costumbres mayas y en el estado creemos en la justicia alternativa y privilegiamos el estado de derecho". Los jueces provienen de los municipios de Tizimín, Chankom, Chikindzonot, Kaua y Cantamayec, ${ }^{138}$ fueron capacitados en talleres para la aplicación de medidas alternativas de justicia y en temas como derechos humanos, mediación y equidad de género; la capacitación se realizó en el municipio de Felipe Carrilo Puerto, del estado de Quintana Roo, con el apoyo del Tribunal Superior de Justicia de esa entidad, a través del magistrado de Asuntos Indígenas, Francisco Javier Reyes Hernández. ${ }^{139}$

Del mismo modo, en 2014 se aprobó la Ley del Sistema de Justicia Maya, la cual, según el presidente de la Junta de Gobierno del Congreso Local, Luis Hevia Jiménez, da certeza y figura legal a los jueces mayas; el Indemaya tendrá la responsabilidad de regular la elección de esa autoridad en cada comunidad; esta ley se complementa con la de Medidas Cautelares (acciones legales que las autoridades correspondientes podrán tomar en procesos penales y con las que se respetan plenamente los derechos humanos de los imputados), y con el nuevo Sistema de Justicia Penal que el 3 de junio de 2014 entró en vigor en todo el Estado. ${ }^{140}$

Con respecto al Registro de comunidades mayas, a mediados de febrero de 2014 se anunció que investigadores de la UADY, auspiciados por la CDI y el Indemaya, realizarán el levantamiento del registro estatal de comunidades mayas en el estado, tras la firma de un acuerdo entre la CDI y el Indemaya. La encargada en la UADY sería la investigadora Rocío Quintal. De acuerdo con ella, el objetivo es conocer qué comunidades se adscriben como indígenas y cuál es su realidad social, cómo enfrentan la

\footnotetext{
${ }^{138}$ Los siete jueces mayas: Mateo Balam Hau de San Isidro Kancabdzonot; Carlos Ku Choc de Nuevo Tesoco, María Feliciana Kuyoc MEdina de Xkalak, comisaría de Tizimín; Sebastián Moo Poot de la comisaría Chan Santa María del municipio de Chikindzonot; Roberto Pool Chan de Cholul, Cantamayec; Braulio Caamal Batún de Muchucuxcáh, Chankom; y Agustín Perera Martín de la comisaría Dzeal en Kaua.

139 Tomado de: <http://a7.com.mx/pulso/seguridad-y-justicia/26527-nombran-a-los-primeros-juecesmayas-en-yucatan.html>.

140 Tomado de La Revista Peninsular, 26 de mayo de 2014. Disponible en línea: <http://www.larevista.com.mx/merida/2014/05/26/3648/legislamos-para-seguir-siendo-un/>.
} 
migración, los servicios de salud y educación, a qué religión pertenecen, cuáles son sus tradiciones, con el fin de definir cuáles son poblaciones mayas. ${ }^{141}$ Cuando a fines de marzo de 2014 se le preguntó a la directora del Indemaya de entonces, Elizabeth Gamboa Solís, por qué no se había iniciado el registro, respondió que aún se tiene que capacitar al personal, a través de la UADY. ${ }^{142}$

\section{Conclusiones}

Acaso una de las primeras conclusiones que pueden esbozarse sobre el proceso antes descrito es que fue finalmente la versión de los diputados de la Comisión del Congreso la que predominó en la Ley aprobada y publicada en 2011. El producto, la "Ley para la protección de los derechos de la comunidad maya del estado de Yucatán”, quedó notablemente limitada al tema de la justicia maya y no abundó en tópicos que fueron demandas centrales de organizaciones y académicos, como la autonomía y el derecho a las tierras y territorios. Sin embargo, como también se apuntó, hay algunos aspectos que sí responden a las demandas de otros actores, como el hecho de que los jueces mayas sean elegidos por las comunidades mayas y no por el Tribunal. ¿Cómo entender este proceso en términos del análisis del poder propuesto en esta tesis?

En cuanto al control de recursos significativos, la Ley no propone ninguna transformación sustantiva de la distribución de recursos y, en ese sentido, parece ilustrar muy bien el "multiculturalismo neoliberal" de Hale. En efecto, fueron excluidas las demandas de organizaciones y académicos que implicaban un mayor control de recursos por parte de comunidades y organizaciones, tales como la reserva de un porcentaje del espectro radioelectrónico de radios comunitarias e indígenas; el presupuesto en comunicación social de los tres niveles de gobierno; el acceso libre a los sitios arqueológicos; la creación de centros de investigación y estudios, de carreras profesionales y de asignaturas sobre cultura y lengua maya en todos los niveles educativos; la creación de una secretaría del pueblo maya y, especialmente, que todas las instituciones públicas cuenten con funcionarios que puedan atender a la población en

\footnotetext{
141 Tomado de: <http://sipse.com/milenio/tomaran-radiografia-a-comunidades-mayas-de-yucatan75773.html>.

142 Síntesis, 27 de marzo de 2014. Disponible en: <http://sintesis.mx/articulos/11706/sin-registro-decomunidades-mayas/yucatan>.
} 
maya, la cual ha sido una de las principales acciones en términos de la demanda de oficialización de la lengua maya.

En donde sí hay cambios en términos del control de recursos es en la figura del juez maya, aunque, como se ha visto, se trata más bien del reconocimiento de algo que existe de facto y no de la creación de un nuevo nivel o dominio de poder. Acaso con la reforma federal del sistema de justicia, los jueces mayas puedan constituirse en alguna suerte de intermediario con mayores atribuciones, pero esto es algo que todavía no podemos concluir. Del mismo modo, apreciamos cambios en la institución indigenista del estado, el Indemaya, al cual se le amplían sus atribuciones para que pueda crear programas de capacitación para formar y acreditar intérpretes y traductores de la lengua maya.

En este orden de ideas, tenemos elementos para argumentar, tal como lo ha hecho Araceli Burguete (2013) para el caso de Chiapas, que si bien los legisladores han reconocido derechos colectivos de los indígenas, lo han hecho de manera limitada, facilitando más la intervención del estado en la vida de las poblaciones que promoviendo una autonomía genuina. Incluso, es importante indagar el argumento de Burguete con respecto a que este multiculturalismo constitucional ha contribuido a instituir un nuevo marco legal, con componentes multiculturales, para facilitar la penetración del capital en las regiones indígenas. El hecho de que el artículo 7 bis de la constitución de Yucatán omita lo relativo a la conservación y mejora del hábitat y la preservación de la integridad de las tierras puede estar relacionado, como observó Monroy (2013:87), con la compra a precios irrisorios de las tierras de los ejidatarios y a su especulación.

Por otro lado, con respecto a los órdenes clasificatorios simbólicos, durante el proceso de legislación encontramos diversas visiones sobre la población maya y su relación con la sociedad más amplia. Si bien algunas organizaciones, como el Consejo de Ancianos y Sacerdotes Mayas, cuyas demandas se centraban en el acceso a sitios sagrados y zonas arqueológicas, parecían reproducir más algunas visiones orientalistas y alocrónicas de la cultura maya, otras organizaciones, como Maya’on, presentaban una visión neocolonial de la problemática étnica en el estado. Es decir, en este orden clasificatorio, la población maya aparece en una relación de asimetría neocolonial, pero al 
mismo tiempo se subraya su historia de resistencia y se propone la construcción de una sociedad intercultural.

Si bien entre los académicos no resultan extrañas las visiones comunitaristas y románticas sobre las poblaciones indígenas, la mayoría de las propuestas estaban encaminadas hacia la construcción de un diálogo y sociedad intercultural, y no simplemente a la conservación de las culturas indígenas.

Con todo, en la Ley aprobada, los principios rectores que la guían son "la preservación de la cultura, la no discriminación, igualdad, solidaridad y armonía social", dejando fuera los principios de interculturalidad y de autonomía que tanto fueron demandados. Del mismo modo, como han observado algunas estudiosas (Duarte 20132014; Mattiace 2013), un tono paternalista y asistencialista permea a la ley, perceptible desde el término de "protección" en su título mismo. De igual forma, en iniciativas anteriores se seguía haciendo referencia principalmente a la cultura maya antigua y sus conocidos logros civilizatorios. También podemos observar que las acciones posteriores de la Comisión del Congreso, encaminadas hacia el reconocimiento del año 2012 como el año de la cultura maya y al Gran museo del mundo maya como elementos para atraer mayor turismo al estado nos sugieren que, a pesar de la Ley, las visiones orientalistas, alocrónicas y mercantilistas sobre la cultura maya seguirán definiendo la línea de acción del estado con respecto a la población maya (tema que será abordado en el próximo capítulo). No obstante, no hay que perder de vista que, como ha observado Sally Moore (1973:730), la legislación consiste en intentos conscientes de dirección social que pueden tener consecuencias deseadas y no deseadas. Los procesos políticos y jurídicos pueden resultar en transformaciones o en la reproducción del orden social, pero sus consecuencias nunca pueden ser advertidas del todo.

Sin embargo, a pesar de que para las organizaciones, académicos y otros actores involucrados en el proceso de legislación la ley resultó en un producto muy limitado, lo cierto es que los derechos humanos y, particularmente, los tratados, acuerdos y otras leyes existentes sobre derechos de los pueblos indígenas siguen siendo un referente importante para las reivindicaciones hechas por los actores mayas en Yucatán. Es decir, a pesar de las limitaciones de la Ley de 2011, el proceso político de legislación, que se remonta hasta la década de los noventa, ha puesto sobre la mesa el tema de los derechos y 
las reivindicaciones del Pueblo Maya se formulan también en un lenguaje de derechos. Retomando el argumento de Laura Valladares (2014) y de Aída Hernández, María Teresa Sierra y Rachel Sieder (2013) relativo a que la fase del multiculturalismo, sobre todo en su aspecto constitucional, está cerrada o agotada, en el próximo capítulo analizaremos cómo una organización conformada por diversos intermediarios celebró un festival maya independiente recurriendo al lenguaje de los derechos de los pueblos originarios para reivindicar al Pueblo Maya. 


\section{CHA'ANIL KAAJ: LA ETNICIDAD COMO PERFORMANCE Y LA CELEBRACIÓN DE UNA "PERFORMANCE ÉTNICA"}

En este capítulo analizaré una de las manifestaciones recientes de la etnicidad maya en Yucatán: el Festival Maya Independiente Cha'anil Kaaj (que puede traducirse como "la fiesta del pueblo") ${ }^{143}$ organizado por el colectivo Yóol Kaaj (el “espíritu del pueblo"). Teóricamente, el análisis estará centrado en la etnicidad como performance a través del estudio etnográfico de una performance. La distinción entre como y una es importante, pues podemos entender la performance no sólo como un género de conducta (tal como obras de teatro, danzas, rituales, festivales, entre otros), sino también como un enfoque de análisis para estudiar diversos fenómenos (por ejemplo, la dimensión performativa de la política, de la economía, del género, etc.). Considero que el análisis de la etnicidad como performance así como el estudio de una performance étnica nos puede arrojar mucha luz para la comprensión del fenómeno del poder y lo político en general, así como de la relación entre poder, política y etnicidad en particular.

¿Cómo entender la relación entre etnicidad y poder a partir de Cha’anil Kaaj? En realidad, considero que existe más de una interpretación posible y que una descripción densa nos daría cuenta de por lo menos los siguientes problemas: 1) el papel de las performances en la crítica al poder. Particularmente, Cha'anil Kaaj cuestiona un orden clasificatorio hegemónico, aquel que conceptualiza a la cultura maya de un modo alocrónico, como algo eminentemente del pasado, y que lo hace con fines mercantilistas. En este sentido, Cha'anil Kaaj puede entenderse en el contexto más amplio de una economía política neoliberal y postindustrial en la cual la mercantilización de la cultura y

${ }^{143}$ Con mayor precisión, Cha'an puede traducirse como "contemplar un espectáculo y gustar de él"; $U$ cha'anil kaaj sería "la fiesta del pueblo": "U, posesivo que funciona como artículo determinado; cha'an, fiesta popular; il, sufijo relacional, y kaaj, pueblo o población); hace referencia a la fiesta del santo patrono del pueblo, la que "une, identifica y hermana a la gente del pueblo" (Güémez 2013). Aquí cabe mencionar que el evento por excelencia es la vaquería (véase más adelante). 
de la diferencia cultural juega un papel de primer orden. 2) Como contraparte del problema anterior, Cha'anil Kaaj, en tanto performance étnica, contribuye a la "emergencia" o gestación de lo que algunos estudiosos han caracterizado como nuevas formas de "indigeneidad" o de mayanidad, es decir, de ser mayas contemporáneos. 3) Para formular su crítica al poder, Cha'anil Kaaj recurre al discurso de los derechos humanos y, particularmente, del de los derechos indígenas. Como vimos en el capítulo anterior, si bien la "Ley para la protección de los derechos de la comunidad maya del estado de Yucatán" resultó sumamente limitada, el discurso de los derechos de los pueblos indígenas sigue siendo un discurso movilizador y una referencia importante para las reivindicaciones del pueblo maya. 4) En un contexto postsocialista, de "fin de las utopías", el Ejército Zapatista de Liberación Nacional (EZLN) aparece como un referente ejemplar de hacer política, sobre todo con sus postulados sobre autonomía y "mandar obedeciendo". Todos estos elementos nos permiten apreciar cómo ciertos actores étnicos, que Luis Vázquez León (2010) ha caracterizado como "pueblo" a propósito de la intelligentsia étnica purépecha, construyen performativamente al "Pueblo Maya". Cabe recordar que afirmar que el "Pueblo Maya" es una construcción no implica necesariamente restar legitimidad a las demandas hechas en su nombre; más bien, nos recuerda que la realidad sociocultural, las relaciones sociales y los significados que la constituyen son construidos históricamente, y que la deconstrucción de categorías como "etnia" nos ayuda a no sucumbir en esencialismos y naturalismos que pueden albergar peligros interpretativos y políticos (Amselle 2010).

El orden de exposición del capítulo es el siguiente. Primero formularé teóricamente el problema de la etnicidad como performance, así como las implicaciones del estudio de las performances étnicas para el análisis del poder. En seguida me detendré en la descripción etnográfica del festival, en la que destacaré las expresiones políticosimbólicas de dicha performance. Por último, abordaré algunas de las principales problemáticas teóricas y políticas que se desprenden del análisis realizado en el capítulo.

\section{La etnicidad como performance y las performances étnicas}

En su notable libro de título marcusiano, Two Dimensional Man, publicado originalmente en 1974, el antropólogo de origen iraquí Abner Cohen puso de manifiesto cómo el 
simbolismo y el poder son dos dimensiones inminentemente inseparables. Cohen reafirmó esta tesis en otro clásico trabajo, su "Political symbolism" de 1979, y desde entonces muy diversos analistas han coincidido en que una antropología del poder que no reconoce los símbolos es vacía, mientras que una antropología simbólica que no atienda las relaciones de poder es ciega (Díaz Cruz 2014). Una ruta privilegiada para el análisis de los cruces entre simbolismo y poder es la del estudio de las performances, formas de praxis eminentemente simbólicas, dramáticas y expresivas que, como bien han documentado Victor Turner (1974), Clifford Geertz (1980; 1987; 1994), David Kertzer (1988), Georges Balandier (1994), entre otros, no son meros decorados del poder sino que son elementos constitutivos de él (ver también Díaz 2008).

En diversas ocasiones se ha hecho alusión a la idea de la etnicidad como performance o la dimensión preformativa de la etnicidad (p.e., Guss 2000; Taylor 2003; Zapf 2006). Sin embargo, para construir el problema con mayor precisión teórica, tomaré como punto de partida la definición de "etnicidad" formulada por el sociólogo Sinisa Malesevic y presentada en el capítulo teórico de esta tesis. Recordemos que, de acuerdo con él, la etnicidad es "la diferencia cultural movilizada por propósitos políticos, cuando los actores sociales a través de procesos de acciones sociales (re) crean narrativas de descendencia común para responder al ambiente social cambiante" (Malesevic 2004:4). De esta definición me interesa destacar dos elementos. El primero es que, como bien sabemos desde tiempos del seminal ensayo de Fredrik Barth (1976) sobre los grupos étnicos y sus fronteras, la diferencia cultural "en sí" no es sinónimo de etnicidad o de un grupo étnico. Sólo cuando un grupo traza fronteras (y, en ese sentido, clasifica la realidad de determinada manera, "ellos-nosotros") con respecto a otro grupo puede hablarse de grupo étnico. Y, como observa Malesevic, se trata de un fenómeno político, en tanto que implica procesos de lucha por el control de recursos y de establecer órdenes clasificatorios.

El segundo elemento que deseo subrayar es que la etnicidad implica la creación de narrativas de descendencia común, y es aquí donde el aspecto performativo cobra una relevancia fundamental. Aquí podemos recordar con Max Weber (2014) que lo importante de las comunidades étnicas no es el pasado común de facto, sino la "creencia 
en un pasado común", "una creencia subjetiva en una procedencia común". Y una forma de creer en una procedencia común es a través de performances.

Ahora atendamos a la cuestión, ¿qué entendemos por "performance"? Como han observado diversos estudiosos, "performance" es un término inestable y controvertido, que posee distintos significados dependiendo de la disciplina y la trama conceptual en que sea ubicado (Bell 1998; Díaz 2008; Madison y Hamera 2006; Taylor 2003). No es mi propósito elaborar una definición unívoca de performance, pero, con el fin heurístico de analizar la etnicidad como performance y las performances étnicas, expondré algunos de sus elementos constitutivos.

En primer lugar, performance puede entenderse como una ejecución o como una acción o práctica. De hecho, el vocablo "performance" proviene de parfounir, que en francés quiere decir "completar" o "llevar a cabo por completo". ${ }^{144}$ En este orden de ideas, el análisis de la performance se centra en las acciones o en las prácticas y no en estructuras o modelos ideales. ${ }^{145}$ Aún más, la performance es una acción o práctica creativa, expresiva, estilizada y figurativa. ${ }^{146}$ Esto nos lleva a pensar en la etnicidad no como algo natural o esencial, sino como algo que se ejecuta en la práctica, ${ }^{147}$ a través de una serie de actos expresivos, estilizados y figurativos.

Un segundo elemento constitutivo de las performances es que se tratan de acciones o prácticas enfáticamente dramáticas. A través de las performances los actores muestran cómo quieren ser vistos por otros; por lo tanto, los otros, la audiencia o los testigos de las performances son también elementos clave en el análisis (Bauman 1975;

\footnotetext{
${ }^{144}$ Aunque, como ha observado Anne Warren Johnson (2014), la palabra francesa parfounir (hacer, llevar a cabo) encuentra sus raíces en las lenguas germánicas, en Fram, que alude al movimiento; en frumjan, movimiento hacia delante; así como en el latín vulgar: fromire-fornire, que quiere decir proporcionar o lograr. Posteriormente, el término francés emigra a Inglaterra, donde se combina con el término forme (forma, belleza). Fue justamente en Inglaterra, en el siglo XVI, cuando perform comienza a emplearse como verbo: la idea de acción o de hacer algo (ver también Taylor 2003:3-4).

${ }^{145}$ Aunque no opone una mutua exclusión entre ambos términos. Más bien, retoma de la teoría de la práctica el análisis de la dialéctica entre acción y estructura (ver Ortner 2006).

146 "Performance, como quiero pensarla aquí —escribe Johannes Fabian (1990:13)—, ciertamente es acción, pero no mera promulgación de un guión preexistente; es hacer, configuración, creación". Asimismo, tómese en cuenta la siguiente consideración de Rodrigo Díaz Cruz (2008:34): el acto de dramatización, lo que aquí denominaré la performance, no es una mera representación, sin mediaciones, de lo que se dice, de lo que está cristalizado en un texto o en un guión preestablecidos, consiste más bien en una traducción, una transformación y, por lo tanto, un desplazamiento, una reelaboración, recreación e interpretación de lo relatado o de lo fijado por medio de la escritura.

${ }^{147}$ Sobre la relación entre etnicidad y práctica (entendida en el sentido de la teoría de P. Bourdieu), véase el trabajo de Bentley 1987).
} 
Fabian 1990). En este sentido de performance resulta valiosa la noción de "ceremonia definicional", ya que "en éstas los grupos se definen como son y como quieren ser, pero también como quieren que los demás los definan” (Díaz 2002:239; ver también Myerhoff 1986). Así, los grupos étnicos, organizaciones étnicas o movimientos étnicos construyen su etnicidad mostrando cómo quieren ser vistos por otros, construyendo narrativas sobre su descendencia común, sobre su diferencia cultural, sobre su papel como víctimas del colonialismo y capitalismo, entre otras narrativas. Acudiendo a Walter Benjamin (2012), podríamos decir que es a partir de estas narrativas que los actores dan sentido a su existencia y constituyen experiencias. Del mismo modo, como observó de manera acertada Georges Balandier (1994) a propósito de la dramaturgia del poder, debemos tener en cuenta que las escenificaciones y dramatizaciones no son meros decorados del poder, sino que son elementos constitutivos de él (ver también Geertz 1980; 1994; Madison y Hamera 2006:XII).

Un tercer elemento constitutivo de las performance es su poder realizativo. Esta idea encuentra una de sus formulaciones clásicas en las conferencias del filósofo del lenguaje John L. Austin (1990) sobre los actos de habla performativos. A diferencia de los enunciados constatativos, que describen cómo es el mundo, los enunciados performativos "hacen cosas", tienen efectos en el mundo. ${ }^{148}$ De acuerdo con Austin, para que los enunciados performativos sean "felices", es decir, para que puedan hacer cosas, "siempre es necesario que las circunstancias en que las palabras se expresan sean apropiadas [...] es menester que el que habla, o bien otras personas, deban también llevar a cabo otras acciones determinadas 'físicas' o 'mentales', o aun actos que consisten en expresar otras palabras" (Austin 1990:49). Entonces, para analizar los enunciados performativos (y lo mismo podríamos decir de todo acto performativo), "tenemos que considerar la situación total en que la expresión [performativa] es emitida" (Austin 1990:95).

Deseo detenerme un momento en el tema de las condiciones de felicidad o infelicidad de los enunciados performativos, pues ha suscitado por lo menos dos discusiones que retomaré en este análisis. La primera de ellas es la crítica de Pierre

\footnotetext{
148 "Indica[n] que emitir la expresión es realizar una acción y que ésta no se concibe normalmente como el mero decir algo" (Austin 1990:47. Cursivas de R.L1.). Un enunciado performativo "no consiste, o no consiste meramente, en decir algo, sino en hacer algo" (Austin 1990:66).
} 
Bourdieu a Austin de atribuir el poder de las palabras a "las propias palabras, es decir, allí donde este poder no está" (Bourdieu 2001:67). No obstante, Austin había argumentado que no son las palabras en sí las que tienen poder performativo, sino que las circunstancias son constitutivas de su poder. Bourdieu repara luego en esto y contraargumenta que "el análisis austiniano de las condiciones de validez y eficacia de los enunciados performativos resulta muy gris y pobre, sólo formalmente ingenioso" (Bourdieu 2001:73). En cambio, atribuye la eficacia de los performativos al poder simbólico: las performances son eficaces porque son enunciadas por personas autorizadas y legítimas, investidas de poder simbólico. ${ }^{149}$ Por lo tanto, no es suficiente señalar que para que un enunciado performativo (por ejemplo, "los declaro marido y mujer") sea "feliz" tiene que ser enunciado por la persona adecuada (el sacerdote y no el acólito). Hay que preguntarse, ¿por qué hay personas autorizadas para enunciar performativos felices?, ¿por qué otras no lo están? Es una pregunta que apunta hacia las relaciones de poder en las performances y que trataré más adelante.

Con respecto a la segunda discusión, el filósofo francés Jacques Derrida (1996) criticó varios de los elementos de la propuesta de Austin (como las ideas de "contexto" e "intencionalidad", así como las categorías de performativos serios y parasitarios), y propuso que los performativos tienen efecto (son "felices") gracias a su citacionalidad, es decir, a que puedan ser extraídos de sus contextos y ser injertados en otros, con nuevos significados (ya que, gracias a su iterabilidad, los signos nunca se saturan de significado). La conocida propuesta de la filósofa norteamericana Judith Butler (2001) sobre la performatividad del género se basa en la concepción de performatividad de Derrida y uno de los argumentos que me interesa retomar de Butler es que la performatividad genera la ilusión de una sustancia (por ejemplo, los performativos de género crean la ilusión de una

\footnotetext{
149 "El poder de las palabras reside en el hecho de que quien pronuncia no lo hace a título personal, ya que es sólo su 'portador': el portavoz autorizado sólo puede actuar por las palabras sobre otros agentes y, a través de su trabajo, sobre las cosas mismas, en la medida en que su palabra concentra el capital simbólico acumulado por el grupo que le ha otorgado ese mandato y de cuyo poder está investido" (Bourdieu 2001:69. Cursivas en el original).Creo que el argumento de Bourdieu no invalida al de Austin: el poder simbólico, o más bien, las personas autorizadas son parte de la "situación total" a la que se refirió Austin, si bien él no se detuvo a analizar las relaciones de poder en la eficacia de los performativos. Sin embargo, creo que la propuesta de Bourdieu tampoco es suficiente, pues habría que preguntarse también por las fuentes del poder simbólico de las personas autorizadas: ¿qué recursos son controlados para ejercer este poder?, ¿se trata sólo de capital simbólico? Y si el portavoz está autorizado por otros, ¿cómo se delega este poder (Adams 1983)? Son preguntas a las que también hay que atender.
} 
sustancia o interioridad del sexo).

Uno de los argumentos centrales de este capítulo es que la etnicidad, en tanto performance, hace cosas. Como veremos más adelante, Cha'anil Kaaj, al presentarse de manera dramática como el "Festival del Pueblo Maya", contribuye a la construcción de la categoría "Pueblo Maya". El poder performativo del festival puede entenderse no sólo por las condiciones en que los actos preformativos son realizados, sino también por los agentes que están autorizados para hablar, así como por la citacionalidad de ciertos discursos (por ejemplo, en torno a los derechos de los pueblos indígenas o de ser víctimas del colonialismo).

A partir de las ideas anteriores podemos argumentar que la etnicidad es performativa en tanto consiste en un conjunto de acciones o prácticas dramáticas por medio de las cuales los actores se presentan a sí mismos ante otros y hacen cosas, en este caso, construyen narrativas de descendencia común, la idea de "Pueblo", así como plantear críticas al poder. Antes de pasar al análisis etnográfico, deseo detenerme en este último elemento.

Parafraseando a David Kertzer (1988) en su trabajo sobre rituales y poder, es posible afirmar que las performances pueden servir lo mismo para contribuir a la preservación del orden y las jerarquías, así como para subvertirlas (ver también Da Matta 2002; Díaz 2008; Guss 2000). Por mucho tiempo, los estudios sobre rituales enfatizaron cómo éstos servían para gestar solidaridad social, mantener el orden, guardar la tradición, entre otros procesos que podríamos considerar que conservan lo establecido (ver Díaz 1998). En este orden de ideas, también se ha mostrado cómo los rituales y las performances sirven para el mantenimiento del poder, ya sea en una tribu o en un moderno Estado nación (Evans-Pritchard 1987; Guss 2000).

Sin embargo, como ya se ha advertido, los rituales y las performances también son celebradas para plantear críticas al poder, por ejemplo, invirtiendo los órdenes clasificatorios hegemónicos, expresando concepciones subalternas de la realidad, manifestando explícitamente demandas y denuncias, entre otras posibilidades. Por ejemplo, Nicole Fabricant y Nancy Postero (2013) han analizado cómo organizaciones de derecha en Bolivia celebran performances que aluden al "indio herido" como un medio para formular críticas y demandas al gobierno de Evo Morales. En el caso que nos ocupa, 
vale la pena recordar que, como ha observado Rodrigo Díaz, los rituales indígenas en México han dejado de ser conceptualizados como "actos extirpables" y cada vez más son entendidos como "actos de identidad colectiva", donde se guardan las tradiciones, así como "actos de resistencia" (Díaz 2002:222). Sin embargo, siguiendo las apreciaciones de Díaz (2002:223), los rituales como actos de resistencia y de identidad colectiva han tendido a subrayar "la unidad de la comunidad donde se celebran dichos rituales".

Como una crítica a esta última observación, algunos estudiosos han enfatizado la naturaleza plural y heterogénea de los rituales y performances, proponiendo el análisis de los diversos "horizontes rituales" en los que se ubican los actores que llevan a cabo dichas prácticas (Guss 2000; Díaz 2002). A continuación describiré algunos de los horizontes rituales o performativos de Cha'anil Kaaj.

\section{Las disputas por el nombre: poder y los usos de lo "maya"}

La idea de crear un festival independiente estaba en mente de muchos mayas, sobre todo al ver la comercialización del nombre de su pueblo para eventos pero que no los incluían.

Presentación del Cha'anil Kaaj, la fiesta del pueblo

Ellos [los del Festival Internacional] tienen el nombre, nosotros tenemos a la gente.

Vicente Canché, maestro y escritor maya

De acuerdo con lo expuesto anteriormente, podemos entender al Festival Maya Independiente Cha'anil Kaaj como una performance étnica, inmerso en un campo de relaciones de poder. Sin embargo, falta precisar en qué sentido dicha performance se relaciona con el fenómeno del poder, por lo que necesitamos una descripción del campo en el que se encuentra ubicada.

Cha'anil Kaaj surgió como una respuesta crítica al anuncio de la celebración del Festival Internacional de la Cultura Maya (FICM) por parte del Gobierno del Estado de Yucatán. ¿Qué fue lo que molestó a los organizadores de Cha'anil Kaaj? En realidad fueron varias cosas, pero uno de los comentarios más recurrentes entre los futuros organizadores del festival maya independiente fue que se usara el nombre "maya" para un festival que no incluía a los mayas. "No es justo que [el FICM] use nuestro nombre", 
expresó Fernando, un comunicador maya, en la primera reunión de organización del Cha'anil Kaaj. ${ }^{150}$ Del mismo modo, en una editorial publicada en uno de los principales periódicos del estado, el Diario de Yucatán, el Dr. Freddy Espadas, economista, antropólogo y pedagogo, escribió que "Lo que se critica enfáticamente es la total ausencia de los mayas actuales en dicho Festival [Internacional de la Cultura Maya] y se hable desfachadamente en su representación; lo que aquí se cuestiona sin ambages es que, mientras se derrochan decenas de millones de pesos en este macroevento, se castigue con presupuestos miserables a los proyectos culturales que municipios, pueblos, comunidades y organizaciones indígenas presentan año con año a la burocracia que regentea la política cultural" (Espadas 2013). Así, desde el inicio, el problema del uso del nombre "maya" se planteaba en términos de "justicia" y de "ausencia de los mayas" en el Festival Internacional.

Pero no sólo se cuestionaba que se usara el nombre y que los mayas estuviesen ausentes. También se criticó cómo se usaba el nombre "maya" con fines mercantiles, instrumentales y, como veremos más adelante, alocrónicos. Una de las académicas más involucradas en la organización de Cha'anil Kaaj declaró que "uno de los motivos del festival es poner un límite al uso inadecuado de la cultura maya, pues carece de un marco de respeto. ¿La razón? Madurez. Ya basta de hacer del pueblo maya un objeto turístico". 151

¿Por qué tanta indignación por el uso del nombre "maya"? Diversos estudios sobre etnicidad han puesto de manifiesto la centralidad del uso de los etnónimos en las reivindicaciones étnicas (ver Kuper 2003; Vázquez 2010). El etnónimo es un emblema simbólico, y al menos desde Émile Durkheim (2000) y Las formas elementales de la vida religiosa sabemos que los símbolos son capaces de movilizar pasiones y afectos. Pero en torno a los nombres y emblemas simbólicos también están en juego otras cosas. En el caso del nombre "maya" podemos advertir una serie de procesos de mercantilización, instrumentalización y otros usos de la diferencia que resultan fundamentales para comprender el tema del poder y etnicidad en la región. Para entender estos procesos me

\footnotetext{
${ }^{150}$ Notas de campo, 4 de julio de 2013.

151 “Otro festival maya 'de y para el pueblo"”. En: Diario de Yucatán, sábado 10 de agosto de 2013. Disponible en línea: <http://yucatan.com.mx/imagen/otro-festival-maya-de-y-para-el-pueblo>.
} 
parece necesario (aunque no sea el objetivo de este capítulo) detenerme un momento en el Festival Internacional de la Cultura Maya (FICM).

El FICM puede entenderse en el marco de un reciente proceso de "revaloración de la cultura maya en Yucatán", como ha caracterizado la antropóloga Nancy Villanueva (2008) al conjunto de políticas en materia de "cultura" en Yucatán. Este proceso, a su vez, se enmarca en el contexto de una economía política "postindustrial", en la que el sector servicios cobra una mayor importancia y en donde la cultura se ha vuelto un privilegiado recurso para obtener ganancias. Si bien en Yucatán este proceso de postindustrialización no ha sido del todo lineal y coherente (ver Baños 2000), tras la crisis de la industria henequenera, otrora el motor económico de la entidad, el sector servicios, especialmente el turismo, tiene un papel fundamental en la actual economía del estado. ${ }^{152} \mathrm{Y}$, ciertamente, la cultura maya, o cierta idea de la cultura maya, es uno de los principales atractivos turísticos de la región. Es en este contexto que diversos actores han expresado su malestar ante la mercantilización de la cultura maya.

Sin embargo, el antecedente más inmediato del FICM es el sensacionalismo provocado por la presunta profecía maya según la cual el fin del mundo tendría lugar el 21 de diciembre de 2012. ${ }^{153}$ El Gobierno del Estado de Yucatán supo aprovechar la atención causada por el augurio, declaró al 2012 "Año de la cultura maya”, e impulsó diversos programas turísticos que tenían como motivo a la cultura maya (o a cierta idea de ella). De este modo, del 14 al 22 de diciembre de 2012 se realizó en la ciudad de Mérida la primera edición del Festival de la Cultura Maya, que tuvo como tema central "El tiempo". El Festival consistió en una serie de actividades artísticas y académicas, y uno de los objetivos principales de los organizadores era "convertir al festival en un proyecto permanente 'que posicione a México y a Yucatán como referencia obligada del turismo cultural internacional"” (Amador 2013). En el marco del Festival de la Cultura

\footnotetext{
${ }^{152}$ En 2001, el turismo aportaba el 21.9\% del PIB estatal en Yucatán. En el Programa Estatal de Turismo de Yucatán 2001-2007 se declara como primer atractivo "los [recursos] arqueológicos que son legado de la cultura maya". De acuerdo con datos correspondientes al 2009, el sector servicios aporta el $71.05 \%$ del PIB estatal. Sobre la relación entre turismo y producción de discursos, prácticas y representaciones de la cultura maya, véase el trabajo de Q. Castañeda (1996).

${ }^{153}$ De acuerdo con el estudioso de códices mayas Nikolai Grube (2010: 34), "no hay ninguna profecía sobre el fin del mundo en el año 2012 en los códices mayas. En ningún lugar de los tres códices mayas los epigrafistas han encontrado señales de profecías apocalípticas relacionadas con una fecha concreta". En torno al 21 de diciembre, ver Elbez (2013).
} 
Maya también fue inaugurado, justamente el 21 de diciembre, el Gran Museo del Mundo Maya, el cual fue galardonado con el Premio Iberoamericano CIDI Obra Emblemática del año 2013 en Arquitectura, Interiorismo, Diseño, Museografía, Iluminación y Edificación por el Consejo Iberoamericano de Diseñadores de Interiores, aunque también ha sido objeto de controversias en torno a la transparencia de los recursos destinados a su construcción así como de su museografía. ${ }^{154}$

La segunda edición del Festival de la Cultura Maya, ahora denominado Festival Internacional de la Cultura Maya (FICM) debido a su vínculo con el Festival Internacional Cervantino (con el cual compartió eventos), fue presentado oficialmente el 19 de junio en el Gran Museo del Mundo Maya Mérida y el 7 de agosto en el Palacio de Bellas Artes de la ciudad de México. Fue a partir de la presentación en Mérida que algunos mayas y no mayas expresaron su indignación ante los usos del nombre "maya" por parte del FICM. Un antropólogo, académico de la Universidad Autónoma de Yucatán (UADY), que fue invitado a la presentación del FICM, me expresó su descontento ante la ausencia de los mayas y por el hecho de que por cultura maya sólo se estaban tomando características de la antigua civilización maya. En efecto, la presentación del FICM en el Gran Museo incluyó la exhibición de un grupo de personas vestidas a la manera de indígenas prehispánicos (ver imagen 1). Al respecto, la apreciación del escritor y periodista Ricardo Tatto (2013) resulta ilustrativa: “desde la misma presentación oficial a mi parecer resultó degradante ver la forma como caracterizaron a los 'mayas' con pintura corporal que resultaba más propia de la próxima película de James Cameron o de la última producción chabacana venida de Hollywood".

${ }^{154}$ Ver, por ejemplo, Izquierdo (2011). 


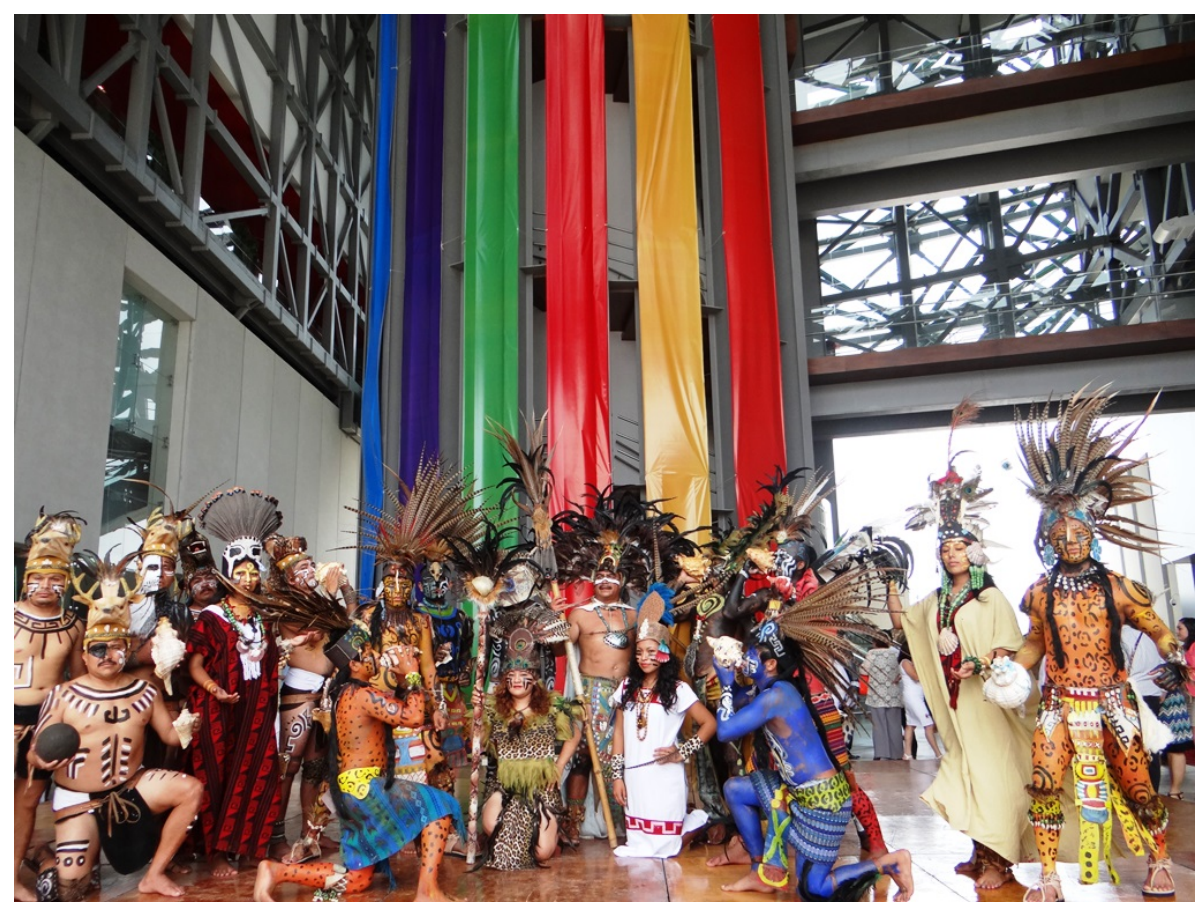

Imagen 1. Presentación del FICM en el Gran Museo del Mundo Maya.

Se trataba, pues, de una representación alocrónica ${ }^{155}$ de la cultura maya: "maya" refiere a la antigua civilización maya, aquella que, presuntamente, predijo el fin del mundo o el fin de una era en diciembre de 2012 y que una vez más era objeto de atracción turística a través de la realización de una multimillonaria performance, el Festival Internacional de la Cultura Maya. Y, de hecho, la referencia de Tatto a la próxima película de Cameron no resulta nada descabellada pues, como ha observado Orin Starn (2011), Avatar puede ubicarse muy bien en el contexto del primitivismo, exotismo y alocronismo antropológico, no sólo de la era victoriana, sino también campante en las amazonias perspectivistas.

Si, por un lado, el FICM de 2013 seguía reproduciendo representaciones alocrónicas de la cultura maya, por otro, era explícito que su objetivo era principalmente turístico. Así, en su página oficial, el FICM reconoce primero al "campo cultural” como "un componente de nuestra economía" y anuncia que pretende "Convertir el Festival Internacional de la Cultura Maya en un proyecto permanente que posicione a México y a Yucatán como referencia obligada del Turismo Cultural internacional”. En su edición del

${ }^{155}$ Sobre el concepto de alocronía y la negación de la contemporaneidad véase el clásico trabajo de J. Fabian (1983). 
2013, el festival tuvo como temática central "El paisaje"; Honduras y Chiapas fueron, respectivamente, el país y el estado invitados de honor, y se estimó la participación de alrededor de mil cuatrocientos artistas y de trescientos cincuenta mil espectadores. Su cuantioso presupuesto, en efectivo y en especie, fue de 75 millones de pesos, con los cuales se organizaron 96 actividades literarias, 28 "encuentros del mundo maya", 200 presentaciones artísticas, 60 actividades académicas, en las que participaron 20 conferencistas, nacionales e internacionales. ${ }^{156}$

Desde luego que, en sí mismo, el objetivo de atraer turismo al estado no resulta desdeñable. El problema es que, como observó un perspicaz editorialista del Diario de Yucatán, la conversión en un "activo que atraiga visitantes a Yucatán" predominaba sobre el propósito de "preservar la identidad cultural maya" (Salgado 2013). Pero aún hay más. El turismo cultural suele ir acompañado de procesos de mercantilización de la cultura, es decir, de la conversión de prácticas culturales en mercancías, donde lo fundamental no es su valor de uso (o utilidad), sino su valor de cambio (o intercambiabilidad en el mercado con el fin de obtener ganancias) (Marx 1975). Ciertamente ya nos encontramos a cierta distancia de los días en los que Davydd Greenwood (1977), en su clásico "Culture by the Pound", denunció el proceso de mercantilización de la cultura como un proceso de destrucción de significados. Otros estudios han mostrado cómo la mercantilización de la cultura ha significado la reinvención de tradiciones e identidades, amén del fortalecimiento de grupos locales (ver Comaroff y Comaroff 2009). Con esto no quiero celebrar la mercantilización de la cultura, sino señalar que no se trata de un fenómeno tan lineal y homogéneo como en algún tiempo se pensó. Lo que sí deseo subrayar es que no podemos pasar por alto que, en tanto mercancía, el bien cultural mercantilizado implica un valor de cambio, y que debemos prestar atención hacia quiénes se benefician con dicho intercambio. ${ }^{157}$

\footnotetext{
156 "Artistas de 30 países participarán en el Festival Internacional de la Cultura Maya”. En: La Jornada, 8 de agosto de 2013. Disponible en línea: <http://www.jornada.unam.mx/2013/08/08/cultura/a07n1cul>.

${ }^{157}$ Lamentablemente, las ganancias generadas por el FICM es un tema que rebasa los objetivos de esta investigación. Pero no resulta difícil concluir que el nombre "maya" se ha vuelto un atractivo turísticomercantil en la región. Uno no necesita aventurarse a la llamada "Riviera Maya" (con lujosos hoteles decorados con motivos pintorescos à la Stephens y Catherwood) para encontrarse con restaurantes y mercancías con el adjetivo "maya", basta con una breve caminata por el centro de Mérida para toparse con más de un vendedor que te ofrezca abanicos hechos en China etiquetados como "abanicos mayas" (lo cual acaso nos habla no sólo de una mercantilización de lo maya sino también de la mayanización de la mercancía).
} 
De este modo, podemos argumentar que en un contexto postindustrial, el nombre "maya", en tanto símbolo, se ha convertido en un recurso significativo cuyo control sirve para obtener ganancias y con ellas ejercer poder. Asimismo, el nombre "maya" se encuentra inmerso en un orden clasificatorio hegemónico que remite a la antigua civilización maya, a la sabiduría, al misterio, al tiempo y a las profecías, a los paisajes pintorescos, pero también, y no de manera menor, al poder y a la obtención de ganancias a través del turismo. Por último, pero no menos importante, la versión alocrónica de la cultura maya, ciertamente magnífica y majestuosa, sirve al simbolismo del poder. Así como la pirámide de Kukulkán en el famoso sitio de Chichén Itzá ha servido como “centro" (Geertz 1994) al simbolismo del poder de gobernantes yucatecos (como en el memorable caso de Felipe Carrillo Puerto en la década de 1920 [ver Urías 2008 y también el capítulo 3 de esta tesis]), el Gran Museo del Mundo Maya y las performances asociadas a él, a saber, los festivales mayas, forman parte constitutiva de las dramaturgias del poder del gobierno de Yucatán y de las empresas asociadas con él. Pero los campos de poder suelen ser controvertidos y los símbolos que los habitan también suelen ser objeto de disputa entre los actores políticos. Y esta no es la excepción.

\section{De dramas sociales y ceremonias definicionales: la emergencia política de Cha'anil Kaaj}

Como ya he mencionado, el anuncio oficial del FICM provocó cierta indignación entre algunos sectores de la población yucateca. En términos de la antropología política procesualista, gestó un "drama social” cuya primera etapa fue la brecha abierta por la celebración de un festival de la cultura maya que usa el nombre "maya" en un sentido mercantilista, instrumental y alocrónico, al mismo tiempo que excluye a la población maya. Tras la brecha sobrevino una crisis en la que la indignación por el FICM se organizó en una propuesta de un festival alternativo: Cha'anil Kaaj. En tanto que los dramas sociales representan una categoría privilegiada para analizar las relaciones de poder, en este apartado describiré la organización de Cha'anil Kaaj como un proceso eminentemente dramático.

Unos días después de la presentación oficial del FICM, Vicente, un joven escritor y maestro maya, convocó a través de su cuenta de Facebook a la organización de un 
festival alternativo que sí tuviese presencia de mayas. ${ }^{158}$ La primera propuesta fue un Festival Independiente de la Cultura Maya con el lema, muy a la usanza zapatista, "Nunca un festival maya sin nuestra gente maya" (ver imagen 2). Vicente subió a Internet un documento en Excel en el que los interesados podían ingresar sus propuestas. Al día siguiente, el documento registraba treinta y cuatro propuestas, las cuales fueron aumentando con el paso de los días.

${ }^{158}$ En su "estado" de Facebook se leía: "PROPONGO: hacer lista de artistas mayas y mandárselo a los organizadores del Festival Internacional de la Cultura Maya, para que hagan un FESTIVAL MAYA donde participe el pueblo maya y lo disfrute, y no un FESTIVAL MAYA con gente que si bien es artista, es ajena al pueblo maya donde solo se codean políticos y gente elitista que solo sabe de MAYAS cuando hay dinero de por medio. Anexen sus nombres y lo que hacen. Compartan y difundan.” 20 de junio de 2013. 


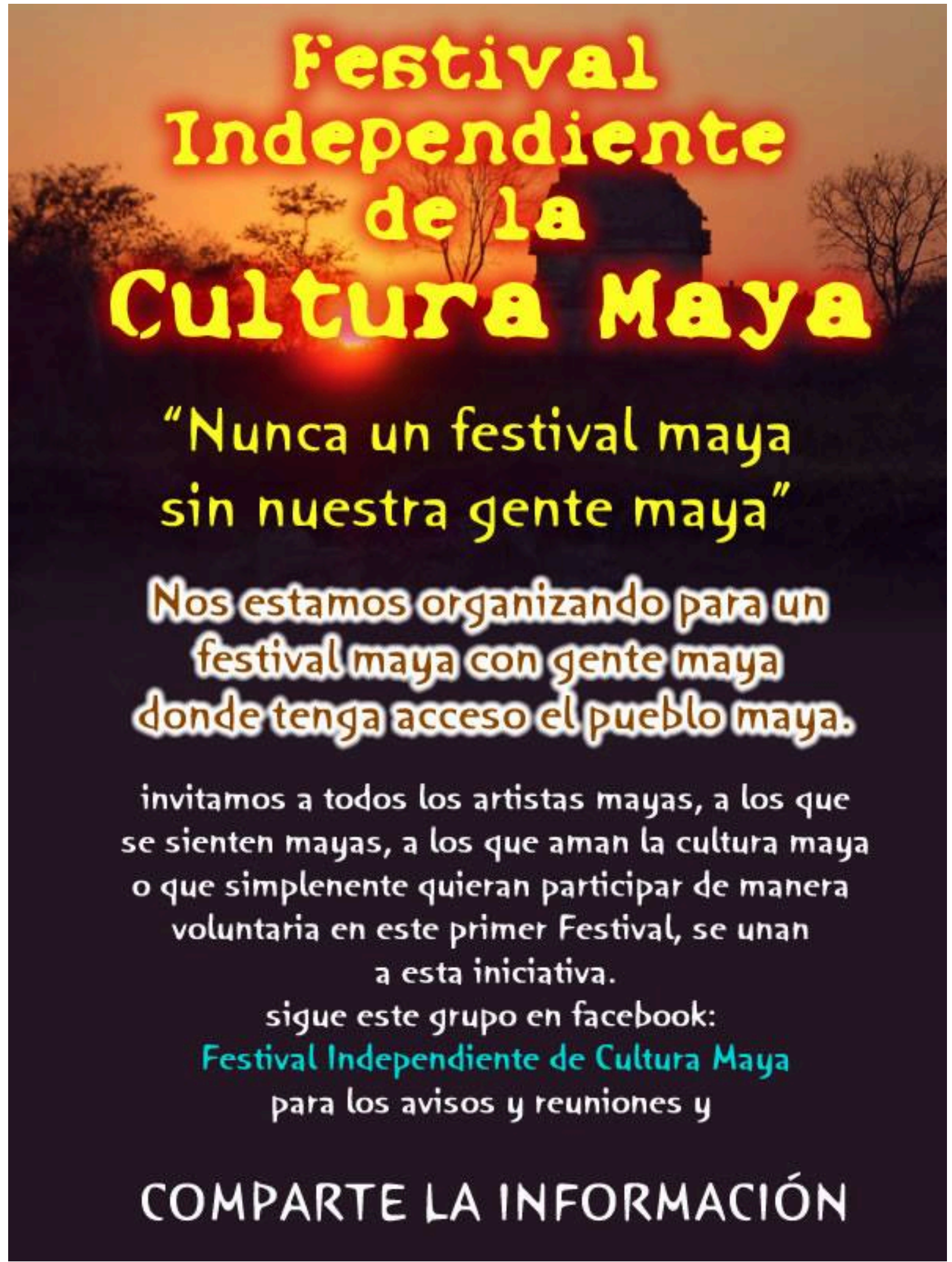

Imagen 2. Primera convocatoria para la organización de un festival independiente de la cultura maya. 
A inicios de julio, los interesados en el festival independiente nos reunimos en un restaurante en el centro de la ciudad de Mérida para discutir la organización del festival. ¿Qué forma de organización y qué normas ideales asumió el grupo que propuso Cha'anil Kaaj? Deseo detenerme en estas preguntas pues resultan clave para entender manifestaciones contemporáneas de la etnicidad, es decir, de la politización de la diferencia cultural.

En cuanto a la forma de organización, primero hay que mencionar que a la primera reunión del festival asistimos cerca de unas sesenta personas, entre ellas académicos, maestros, promotores culturales, miembros de organizaciones de la sociedad civil, así como empleadas del Instituto de Historia y Museos de Yucatán, el instituto encargado de la organización del Festival Internacional de la Cultura Maya, quienes, en un intento de "acción reparadora" (tercera fase de los dramas sociales), ofrecieron colaborar con el festival independiente. En las siguientes reuniones (todas fueron los jueves en el mismo restaurante) el grupo se redujo a un aproximado (pues la cantidad fluctuaba) de treinta personas. La mayoría de los organizadores provenía de Yucatán; más de la mitad son maya hablantes, y en el colectivo encontramos investigadores de la Universidad Autónoma de Yucatán (principalmente del área de antropología, historia y educación), estudiantes de dicha universidad (en las mismas áreas), comunicadores, escritores, promotores culturales, profesores bilingües, activistas y participantes en movimientos sociales y organizaciones de la sociedad civil. La forma de organización adoptada por el grupo no fue un partido político o una asociación civil, sino un colectivo, que a la postre se llamaría Yóol Kaaj (“el espíritu del pueblo”).

Yóol Kaaj puede ser enmarcado en el contexto de la política de postguerra fría. Por un lado, tras la crisis del socialismo real, ni el marxismo, ni el comunismo, ni alguna otra forma de socialismo aparece como el referente más atractivo para el movimiento. Pero, lejos de sucumbir en el "fin de la historia” y en la crisis de las utopías, Yóol Kaaj y, con él, Cha'anil Kaaj, sí tiene una utopía como referente: se trata del Ejército Zapatista de Liberación Nacional y sus planteamientos sobre autonomía y el "mandar obedeciendo" (aunque en el colectivo también aparecen otros referentes como el "Buen Vivir" de los países andinos así como los movimientos indignados en Europa y otras partes del mundo). Por otro lado, aunque estrechamente vinculado con lo anterior, Yóol Kaaj 
también puede entenderse en términos de lo que la filósofa Nancy Fraser (1997) ha caracterizado como un desplazamiento de los movimientos sociales que luchan por la redistribución socioeconómica a los que lo hacen por el reconocimiento. A partir de la conjunción de ambos elementos, Yóol Kaaj se propuso el reconocimiento del pueblo maya a través de una performance organizada de manera autónoma, Cha'anil Kaaj.

Acaso un ejercicio comparativo entre los dos festivales, el FICM y Cha'anil Kaaj, pueda delinear con mayor nitidez la forma como Yóol Kaaj se presentaba performativamente. Debo aclarar que se trata de una comparación desde la perspectiva de Yóol Kaaj pues, como mostraré más adelante, en la práctica es posible distinguir ciertos matices que en el discurso no son destacados.

En primer lugar, retomando el lenguaje neozapatista, algunos integrantes de Yóol Kaaj caracterizaron al FICM como el festival del "mal gobierno". En contraparte, Cha'anil Kaaj era el festival del "pueblo maya". En segundo término, como ya se ha visto, para los integrantes de Yóol Kaaj el FICM tenía un objetivo fundamentalmente mercantil y turístico que, de nuevo, no respondía a los intereses del "pueblo" sino del "mal gobierno"; en cambio, Cha'anil Kaaj tenía un objetivo social y cultural, sin fines de lucro. Vale la pena detenerse en el objetivo de Cha'anil Kaaj.

De acuerdo con su página en Internet, el objetivo de Cha'anil Kaaj es “visibilizar a un pueblo maya contemporáneo y de raíces históricas fuertes, que tiene expresiones artísticas, culturales y sociales que pueden enriquecer a la sociedad en la cual se encuentra inserto". ${ }^{159}$ La palabra visibilizar es clave pues, desde la perspectiva de Yóol Kaaj, el pueblo maya contemporáneo ha sido invisibilizado gracias a la exaltación de una imagen mercantilista y alocrónica de la cultura maya entendida como la antigua y gloriosa civilización maya. Por lo tanto, podemos entender Cha'anil Kaaj como una "ceremonia definicional", es decir, como una performance a través de la cual una colectividad invisibilizada exhibe imágenes para visibilizarse, crear presencia y reclamar derechos. Si el FICM presentaba una cultura maya muerta y del pasado, Cha'anil Kaaj era la muestra de una cultura viva y contemporánea. Más adelante volveré sobre esta idea.

${ }^{159}$ Tomado de: <http://www.chaanilkaaj.org/es/>. 
Antes he mencionado que uno de los principales referentes de Cha'anil Kaaj es el EZLN. ¿Cómo se presentó esta influencia? Algunos integrantes de Yóol Kaaj expresaron en diversas ocasiones que Cha'anil Kaaj no tenía un carácter "político", sino que era "cultural". En realidad, se referían a que Cha'anil Kaaj no tiene una filiación partidista. Pero resulta interesante considerar algunas de las afirmaciones por parte del colectivo acerca del carácter político del festival, pues nos ayudan a comprender el discurso y formas de organización. Por ejemplo, una economista, historiadora e investigadora de la UADY interpretaba lo político como un sentido de crear o hacer presencia. Para ella, el festival respondía a un proceso de quinientos años (en referencia a la Conquista europea) y que, además, no lo hace de manera beligerante, sino a través de una gran fiesta, a la manera del EZLN. A la postre, varios integrantes de Yóol Kaaj participarían en la escuelita zapatista a finales de 2013, así como en el Primer Festival Mundial de las Resistencias y Rebeldías contra el Capitalismo en diciembre de 2014.

Del mismo modo, si con la antropología política procesualista entendemos lo político como una dimensión de todo fenómeno social que tiene como elemento característico la búsqueda pública de metas, podemos apreciar que Cha'anil Kaaj era político en tanto que sus organizadores se trazaron diversas metas públicas. Además del objetivo de visibilización antes mencionado, los integrantes del colectivo compartían otros fines. Uno de ellos se expresaba de manera negativa: no buscaban la confrontación con o la crítica al FICM, sino que, en términos positivos, luchaban por la afirmación del pueblo maya. Por ejemplo, un joven escritor consideraba que "no es necesario que el festival tenga un carácter confrontativo, reconocer la autonomía de la cultura maya es suficiente para organizar el evento". No obstante, como observó uno de los integrantes del colectivo, el rechazo al carácter confrontativo también puede entenderse como un temor de quienes trabajan en instituciones oficiales a poner en riesgo sus empleos. El mismo integrante invitaba a usar la confrontación de manera inteligente, por ejemplo, a través del recurso a la historia (como la guerra de castas).

Otro de los objetivos del colectivo era la autonomía, entendida como la capacidad de decisión. La autonomía es tanto una norma ideal como una forma de organización, la cual se vincula con otros principios organizativos, sobre todo con el dictum zapatista de "mandar obedeciendo". Uno de ellos es el carácter horizontal del colectivo, es decir, que 
no posee líderes, jefes, presidentes o algún tipo de centro vertical que tome las decisiones. "Trabajar en red, no de forma jerárquica", expresó uno de los integrantes del colectivo. Otro es el carácter abierto e inclusivo del grupo: cualquier simpatizante con el pueblo maya puede formar parte de él. Un aspecto más es la autogestión: Cha'anil Kaaj debería realizarse con recursos propios, no del gobierno; en caso de no poseer los recursos, se debía acudir a la solidaridad y ayuda mutua de las redes de relaciones. Sobre todo, la independencia del gobierno era para muchos integrantes del colectivo uno de los aspectos centrales del festival. Así, la organización autónoma, horizontal, abierta y autogestiva constituye para Yóol Kaaj una tercera diferencia con respecto al FICM, al cual consideran vertical, cerrado y excluyente.

Cabe recordar que la autonomía y la horizontalidad son principios tanto organizativos como ideales. En la práctica, dichos principios se encontraban con diversas controversias y disputas. Por un lado, algunos integrantes del colectivo, sobre todo académicos y un reconocido escritor, solían figurar como "centros" del grupo: eran quienes conducían algunas reuniones o cuyas opiniones solían tener más peso. Por otro lado, en ocasiones, integrantes del colectivo manifestaban su descontento con la idea de horizontalidad, pues señalaban que las reuniones y la toma de decisiones se hacía más lenta e ineficiente. Ante dichas situaciones, algunos integrantes del colectivo enfatizaban la importancia de la horizontalidad, expresando que lo importante no es la duración de las reuniones (solían ser de aproximadamente tres horas por semana, sin contar el tiempo dedicado en las redes sociales), sino escuchar todas las voces del colectivo. ${ }^{160}$ De esta forma, Yóol Kaaj se organizó a partir de una serie de comités sin líderes o directivos, y cada comité estaba dedicado a un tipo de actividad en el festival: comunicación, literatura, música, talleres y cursos, academia, audiovisual, vinculación y de redacción del manifiesto.

Como ya he señalado, Cha'anil Kaaj también fue presentado por sus organizadores como una muestra de la cultura maya viva y contemporánea. En este sentido, un elemento importante de la organización del grupo fue el uso de las nuevas

\footnotetext{
${ }^{160}$ A propósito del clásico ensayo de Pierre Clastres, La sociedad contra el Estado, podemos recordar que la horizontalidad no es un atributo natural de los grupos considerados más simples (ya sea una banda de recolectores y cazadores o un colectivo como Yóol Kaaj), sino que es el resultado, nunca definitivo, de una controversia entre procesos de centralización y de descentralización.
} 
tecnologías de información y comunicación, particularmente de la red social Facebook. Al respecto, cabe destacar que Vicente, quien, como hemos visto, lanzó la convocatoria para realizar el festival, ha expresado en diversas ocasiones que las nuevas tecnologías deben ser empleadas para la revaloración de la cultura maya. Si bien el colectivo se reunía cada jueves, la comunicación a través de Facebook se llevaba a cabo prácticamente todos los días de la semana. Asimismo, otros espacios electrónicos fueron clave para la visibilización del colectivo. Tal es el caso del video "Presentación del Cha'anil Kaaj, la fiesta del pueblo", el cual fue subido a YouTube. ${ }^{161}$ El colectivo se define en el video como "somos el pueblo maya y lo queremos celebrar con una gran fiesta, la fiesta del pueblo [cha'anil kaaj]" y exponen el objetivo (ligeramente distinto al de la página de Internet): "Nuestro objetivo: reivindicar el pensamiento del pueblo maya contemporáneo". Es decir, las nuevas tecnologías de información y comunicación también pueden servir como elementos ceremoniales-definicionales. Sobre esto volveré en el siguiente capítulo.

Asimismo, un elemento notable de Cha'anil Kaaj es que, si bien se trataba de hacer política de manera festiva, performativa, para hacerlo retomaba el discurso de los derechos humanos y de los derechos indígenas. Así, eran constantes las alusiones a la legislación sobre derechos indígenas, particularmente al Convenio 160 de la OIT y a la Ley General de Derechos Lingüísticos de los Pueblos Indígenas. En este sentido, podríamos decir que el discurso del festival era la de los derechos de los pueblos indígenas. Entre las demandas planteadas se encontraban la oficialización de la lengua maya, la solicitud de que no se use más el nombre del "pueblo maya" en alguna actividad que no tenga que ver con él, que los mayas manejen los recursos que son designados para ellos, así como la reivindicación de la cultura maya actual. Cabe destacar que no se retomaba la "Ley para la protección de los derechos de la comunidad maya del estado de Yucatán" y, cuando se hacía referencia a ella, se le mencionaba como una ley del estado o del mal gobierno, ajena al pueblo maya.

${ }^{161}$ El video puede verse en: $<$ http://www.youtube.com/watch?v=GkzmxZhD5iI $>$. 


\section{Las performances étnicas}

Si, según los integrantes de Yóol Kaaj, en el FICM estaban ausentes los mayas, ¿cómo podrían estar presentes los mayas en Cha'anil Kaaj? No se trataba sólo de que quienes organizaran fueran mayas. Cha'anil Kaaj debía ser del "pueblo maya" y para el "pueblo maya". En este sentido, uno de los objetivos fundamentales del festival era que sus actividades tuviesen un sentido local y que fuesen accesibles para todos. A continuación presentaré una sucinta descripción de las actividades del festival, con el fin de destacar el tipo de actividades realizadas así como las sedes donde fueron llevadas a cabo.

El festival consistió en un total de 78 actividades programadas. La mayoría de ellas, 57, tuvieron lugar en Yucatán; 19 se realizaron en Quintana Roo, casi todas en la Universidad Intercultural de Quintana Roo; 1 se llevó a cabo en Campeche; 2 fueron celebradas en los Estados Unidos; y una más tuvo sede en Guatemala. Ciertamente, la mayoría de las actividades en Yucatán, 37, se concentraron en el municipio de Mérida, pero otras 20 pudieron realizarse en otros municipios del estado. ${ }^{162}$

La mayoría de las actividades del festival, 22, fueron de carácter académico, principalmente conferencias, mesas panel, así como presentaciones de libros y revistas. Después encontramos las actividades literarias, 20, distribuidas entre recitales, presentaciones de libros, puestas en escena de obras de teatro así como el Gran Coloquio Kjaajalt'aan "Nuestra verdadera palabra". En el marco del festival también se realizaron 7 talleres, 6 eventos musicales, 5 proyecciones de documentales y otros materiales visuales, 3 exposiciones fotográficas y 2 eventos de danza. Asimismo, podemos considerar un amplio rubro de "otras actividades", donde se llevaron a cabo, además de la inauguración y clausura del festival (que incluyeron diversos tipos de actividades), una caravana cultural, un foro radiofónico, observaciones lunares, una ceremonia del "Fuego nuevo", una ofrenda floral, una rodada ciclista, jornadas culturales, un encuentro virtual con migrantes mayas en los Estados Unidos, una acampada, la presentación de un libro sobre Escuelas campesinas, así como la presentación de la Preaudiencia “Táan u xu’ulsal

\footnotetext{
${ }^{162}$ Cabe aclarar que una actividad fue realizada de manera paralela en Estados Unidos y Yucatán (en Oxkutzcab) y una comenzó en Quintana Roo y finalizó en Yucatán (también en Oxkutzcab).
} 
k-kuxtal" (Están acabando con nuestra vida) del Tribunal Permanente de los Pueblos, Capítulo México, Mérida. ${ }^{163}$

De esta breve descripción de las actividades del festival se pueden derivar diversas apreciaciones. En primer lugar, Yóol Kaaj cumplió uno de sus cometidos que era realizar el festival más allá de la ciudad de Mérida e incluso de Yucatán. Cha'anil Kaaj tuvo presencia en toda la península, especialmente en Quintana Roo, gracias a la colaboración de la Universidad Intercultural Maya de Quintana Roo, e incluso fuera de México, gracias a los vínculos con organizaciones en Guatemala y en San Francisco, California. Cabe destacar el hecho de que se hayan realizado actividades en diversos municipios del estado de Yucatán, pues esa era una de las formas a través de las cuales, según Yóol Kaaj, Cha'anil Kaaj sería un festival del pueblo. En este sentido, es notable que la inauguración haya incluido un ritual que es considerado tradicional en Yucatán, la vaquería, y que se haya realizado en Oxkutzcab, al sur de Yucatán. Pero esto no debe hacernos pensar, como en ocasiones se enfatizaba en el discurso, de que era un festival del pueblo opuesto en oposición al gobierno. De hecho, la colaboración de las autoridades municipales, sobre todo en municipios gobernados por el Partido de la Revolución Democrática (PRD) y el Partido Acción Nacional (PAN), fue clave para realizar las actividades.

La inauguración de Cha'anil Kaaj se llevó a cabo el 12 de octubre de 2013. La fecha, desde luego, es un elemento en sí mismo simbólico, pues Yóol Kaaj decidió iniciar el festival el día de la celebración del respeto a la diversidad cultural. También habían propósitos políticos, como la "descolonización" de fechas (el 12 de octubre no como celebración del "descubrimiento" de América, sino de la diversidad cultural), pero, del mismo modo, se consideraba que las fechas del festival internacional no respetaban las costumbres y festividades locales, pues coincidían con la celebración del día de muertos.

Además de la vaquería, la inauguración recibió a una caravana que salió de Felipe Carrillo Puerto, Quintana Roo, la cual rindió tributo a los héroes mayas de la guerra de castas; también contó con la participación de un grupo de teatro independiente local de Oxkutzcab, Chan Dzunu'un, dirigido por la reconocida escritora maya María Luisa

${ }^{163}$ El lector se dará cuenta que el total de las actividades suma más de 78. Ello se debe a que algunas actividades entran en más de una categoría (por ejemplo, se hicieron recitales poético-musicales, así como talleres sobre literatura). 
Góngora Pacheco, que puso en escena una obra hablada en lengua maya sobre los aluxoob (los pequeños duendecillos mayas protectores de los espacios) y extranjeros; con el rapero maya Pat Boy; el grupo de música Timoteo Nah y las Chicas Nah; y la jarana, a cargo de la Orquesta Jaranera de Arturo González, que invitó al baile a los participantes hasta bien entrado el día siguiente.

No cuento con información precisa sobre la procedencia de los asistentes a la inauguración. Por algunos comentarios entre el público, puedo intuir que la mayoría era de Oxkutzcab o de localidades cercanas. Por lo menos, algunos integrantes de Yóol Kaaj expresaron su satisfacción al notar que la gente de la localidad había asistido. También es de notarse que el público rió con la obra de teatro en maya y bailó con la música interpretada. En este sentido, Cha'anil Kaaj se constituía como un festival del pueblo. Pero también resulta interesante un pequeño suceso, pero no por ello poco significativo, ocurrido durante la inauguración. Durante su presentación, el rapero Pat Boy pidió al público que alzaran la voz todos los mayas vivos. Nadie alzó la voz. Una persona junto a mí comentó, en son de broma, "no saben que están vivos". Acaso una respuesta más adecuada pueda ser la de "no saben que son mayas". Es decir, si bien la inauguración pudo resultar atractiva como una fiesta local, como muchas que se realizan en las localidades yucatecas, el discurso etnicista que reivindica a la cultura maya no parece haber encontrado mucho eco entre los asistentes. Ser maya hablante, vivir en el sur de Yucatán y llevar a cabo algunas de las prácticas consideradas "mayas" por los antropólogos y otros estudiosos no es sinónimo de reivindicar una identidad étnica maya.

Del mismo modo, no debemos pensar que porque la inauguración haya incluido una fiesta tradicional, como la vaquería, y que haya sido en Oxkutzcab, Cha'anil Kaaj sea un festival del pueblo opuesto al festival internacional del gobierno. Como ya he mencionado, la realidad es mucho más compleja que dicha oposición binaria. Para el caso que nos ocupa, es de observarse que fue el ayuntamiento de Oxkutzcab quien aportó diversos recursos claves para la inauguración, tales como la tarima, el equipo de sonido y el servicio de venta de cervezas. Lo que importa, en términos socioculturales, es que performativamente la inauguración, junto con otras performances del festival, contribuyeron a la visibilización del pueblo maya y a su oposición con el "mal gobierno". 
Otro aspecto que cabe destacar de la composición de las actividades de Cha'anil Kaaj es el predominio de eventos académicos. Me parece que ello se debe, en gran medida, a la notable participación de académicos (principalmente de la Universidad Autónoma de Yucatán) en la organización del festival. Con esto no quiero acusar una suerte de impureza en la organización del festival. Todo lo contrario. Considero que no podemos entender las movilizaciones étnicas como expresiones políticas únicamente de sujetos que se reconocen como indígenas, sino que también abarcan las redes que tejen con otros actores. En estas redes los académicos, especialmente los provenientes del ámbito de las ciencias sociales, suelen jugar un papel de primer orden. Aquí encontramos una "doble hermenéutica", donde la producción cultural de las ciencias sociales (en este caso, las ideas del antropólogo Guillermo Bonfil Batalla o del sociólogo Boaventura de Sousa Santos) y de los actores étnicos entran en un proceso de acercamiento de horizontes. Desde luego, muchos de dichos actores étnicos también son académicos. También habría que estudiar con más detalle las nuevas expresiones de activismo antropológico, como las que se desprenden de las propuestas de investigación colaborativa y dialógica. Así, entre los eventos académicos cabe mencionar una mesa panel dedicada al EZLN, así como páneles de carácter dialógico, como el encuentro entre especialistas en medicina tradicional con parteras y curanderas. No obstante las propuestas de realizar los eventos académicos fuera de la ciudad de Mérida con el fin de difundir la producción científica sobre el pueblo maya, la mayoría de las actividades académicas tuvieron lugar en la capital del estado.

Después de las académicas, las literarias fueron las actividades con mayor presencia en Cha'anil Kaaj. Probablemente, esto se debe a que la literatura es uno de los ámbitos donde la etnicidad maya se ha expresado de manera más notable. Las principales demandas de la movilización étnica en Yucatán se han formulado en torno a la lengua maya, y la literatura es uno de los ámbitos donde ella puede ser preservada, difundida y actualizada. Así, la literatura no constituye una práctica meramente artística, sino también política, pues ha servido para plantear demandas en torno a la preservación, difusión y actualización de la lengua maya al estado. En este orden de ideas, a juicio de los organizadores de Cha'anil Kaaj, uno de los eventos considerados más importantes fue el Gran Coloquio Kjaajalt'aan "Nuestra verdadera palabra". 
Los eventos sobre literatura maya fueron en su mayoría bilingües, con cierto predominio de la lengua maya sobre el castellano. Si bien las temáticas de las obras recitadas y presentadas no siempre son explícitamente políticas (más bien se retoman por lo general temas románticos y costumbristas de la región), sí se presenta un discurso de afirmación, "nosotros los mayas", e incluso, en uno de los recitales, un escritor expresó de manera enfática que el objetivo de su literatura no era la obtención de ganancia, sino la cultura (maya), afirmación que puede ser entendida en el contexto de la crítica de Cha'anil Kaaj a la visión mercantilista de la cultura presente en el FICM.

Por lo que respecta al Gran Coloquio Kjaajalt'aan, hay que aclarar que no se trataba sólo de literatura, sino sobre cualquier tipo de trabajo con la palabra maya. Quien lo propuso, el reconocido escritor maya Feliciano Sánchez Chan, explicó que ya se han presentado muchas ideas en torno a qué hacer con respecto a la lengua maya, pero que aún no se ha aclarado cómo se van a realizar. Por lo tanto, el objetivo del Gran Coloquio era explorar los cómo. Al iniciar el evento, Sánchez pidió que el auditorio tomara la decisión de en qué lengua iba a ser el evento, pero aclaró que él pensaba que debía ser en maya.

En realidad, las presentaciones fueron bilingües en maya y castellano. En su intervención, la informática Daniela Esther Cano Chan abordó el tema de la enseñanza oficial de la lengua maya y propuso que debe implementarse desde el nivel preescolar. Del mismo modo, propuso la organización "desde nuestras comunidades, organizar talleres de literatura, asistir a festivales". De lo contrario, aseveró, "seremos como títeres que sólo nos usan cuando nos necesitan". Por su parte, Antonio Romero propuso eliminar todos los préstamos del español de la lengua maya. Una forma concreta de hacerlo, explicó, consiste en hacer una lista con las palabras en español con sus equivalentes mayas y pegarlas en las comisarías. Las equivalencias también podrían difundirse a través de la radio y el teatro guiñol. El objetivo es "limpiar la lengua maya de los préstamos". Sobre este tema, Feliciano Sánchez intervino expresando que también se violenta la lengua maya cuando se habla con palabras mayas pero se usa la estructura del español.

En el Gran Coloquio también participó el colectivo Múuch Kaanbal, el cual desde 2007 ha estado trabajando en la zona oriente de Yucatán. El colectivo expuso el "método 
inductivo intercultural" con el cual trabajan. Su objetivo no es sólo visibilizar la lengua maya, sino todo el conocimiento que está siendo desvalorizado. Sus convicciones son que se construye desde abajo y desde adentro, viviendo y participando en comunidad, "resignificando nuestra identidad". A partir de él, por ejemplo, retoman las enseñanzas de los abuelos en torno a la relación del hombre con la naturaleza (pedirle permiso, agradecerle). Con este método han construido un calendario que integra y articula conocimientos universales (provenientes, por ejemplo, de la ciencia europea), nacionalesescolares e indígenas. Un punto que cabe destacar es que los integrantes del colectivo expresaron que se basan en el Convenio 169 de la OIT y que tienen el derecho a exigir cómo quieren ser educados y qué conocimientos quieren. Uno de sus objetivos es crear un currículum con contenido propio que sea completamente en lengua maya.

La escritora Patricia Martínez Huchim presentó en el Gran Coloquio un proyecto editorial independiente consistente en historietas en lenguas maya, las cuales recrean historias de las comunidades y están dirigidas principalmente a niños. Por su parte, el también escritor Vicente Canché expuso varias cuestiones críticas con respecto a la situación de la lengua maya en Yucatán. Señaló primero que el festival internacional lanzó una convocatoria de concurso de cuento maya pero con un premio de 20 mil pesos, bastante limitado en comparación con el concurso municipal de Calkiní, Campeche, que es de 100 mil pesos. También cuestionó la falta de difusión de la Ley General de Derechos Lingüísticos, señalando la desproporción entre el tiraje de la ley impresa y el número de maya hablantes, así como la falta de evaluación de las leyes, programas y propuestas relacionadas con la lengua maya. Por otra parte, propuso la creación de una carrera para profesores de lengua maya.

Por último, en su intervención, Feliciano Sánchez presentó un contraste entre el gobierno y el pueblo. "Donde el gobierno se mete todo lo echa a perder", expresó, mientras que "en nuestro pueblo la producción, acceso, uso, disfrute de los conocimientos es eminentemente colectivo, no es de nadie, es de todos". Junto a esta oposición presentó otra: entre el pensamiento occidental y el pensamiento de los pueblos indígenas. Esta oposición entre esquemas conceptuales se expresa de manera conflictiva, por ejemplo, en temas de derechos de autor de las creaciones literarias: ¿quién es el autor de las historias 
locales de una comunidad recopiladas en una obra?, ¿se le debe llamar recopilación o recreación?

Así, en el Gran Coloquio se puede apreciar una diversidad de posturas: desde algunas más puristas y que plantean una oposición entre esquemas conceptuales diferentes (maya y occidental), hasta propuestas de diálogo e intercambio cultural. Pero, en todos los casos, se trató de la reafirmación de la identidad del pueblo maya y de la importancia de la lengua para dicha identidad. Asimismo, si bien se hablaba sobre la lengua y literatura, podríamos decir que el idioma con el cual se hablaba sobre dichos temas era el de los derechos, con referencias constantes al Convenio 169 de la OIT y a la Ley General de Derechos Lingüísticos.

A propósito de la crítica de Bourdieu a Austin sobre quiénes tienen el poder simbólico para que los enunciados preformativos sean "felices", cabe destacar aquí la participación de Feliciano Sánchez en el Gran Coloquio. Su voz era la más autorizada, no sólo por ser el organizador del evento, sino también por el reconocimiento que tiene como escritor y promotor cultural en el estado. ${ }^{164}$

Si bien la identidad étnica maya se reafirmaba a través de distintas actividades consideradas comúnmente "culturales" así como académicas, el festival también contó con eventos explícitamente políticos. El panel de discusión "El neozapatismo y su influencia en la revaloración del pueblo maya" fue uno de ellos, en donde se reconoció la importancia de dicho movimiento y su proyecto de autonomía en la lucha del pueblo maya de Yucatán. El discurso zapatista estaba presente en Cha'anil Kaaj, como en la constante expresión "Nunca más un festival sin nosotros". Otra actividad abiertamente política fue el panel "Las estatuas de los Montejo: apología del genocidio". El panel fue propuesto por la antropóloga Ella Fanny Quintal y realizado en la glorieta donde están erigidas las estatuas de Francisco de Montejo padre y su homónimo hijo, considerados los fundadores de Mérida, en el remate del Paseo de Montejo, conocida avenida de Mérida de notable influencia parisina. La estatuas fueron levantadas en 2010 en el contexto de la celebración del bicentenario de la Independencia de México y el centenario de la

\footnotetext{
${ }^{164}$ Por ejemplo, el periódico El Universal sacó una nota del Gran Coloquio, pero sólo hizo referencia a las declaraciones de Feliciano Sánchez. Ver: "Lamentan combinación del idioma maya y el español”. En: El Universal, 19 de octubre de 2013. <http://www.eluniversal.com.mx/cultura/2013/lamentan-idioma-mayaespanol-combinacion--959423.html>.
} 
Revolución Mexicana. Desde entonces, un par de grupos, "Vamos a tirar el racismo y la discriminación" y "Los que no queremos una estatua de Francisco de Montejo en Mérida", han propuesto desde derribar las estatuas hasta realizar actos de desagravio en el sitio, pues consideran al monumento como una apología al colonialismo, racismo y al genocidio (ver imágenes 3 y 4).

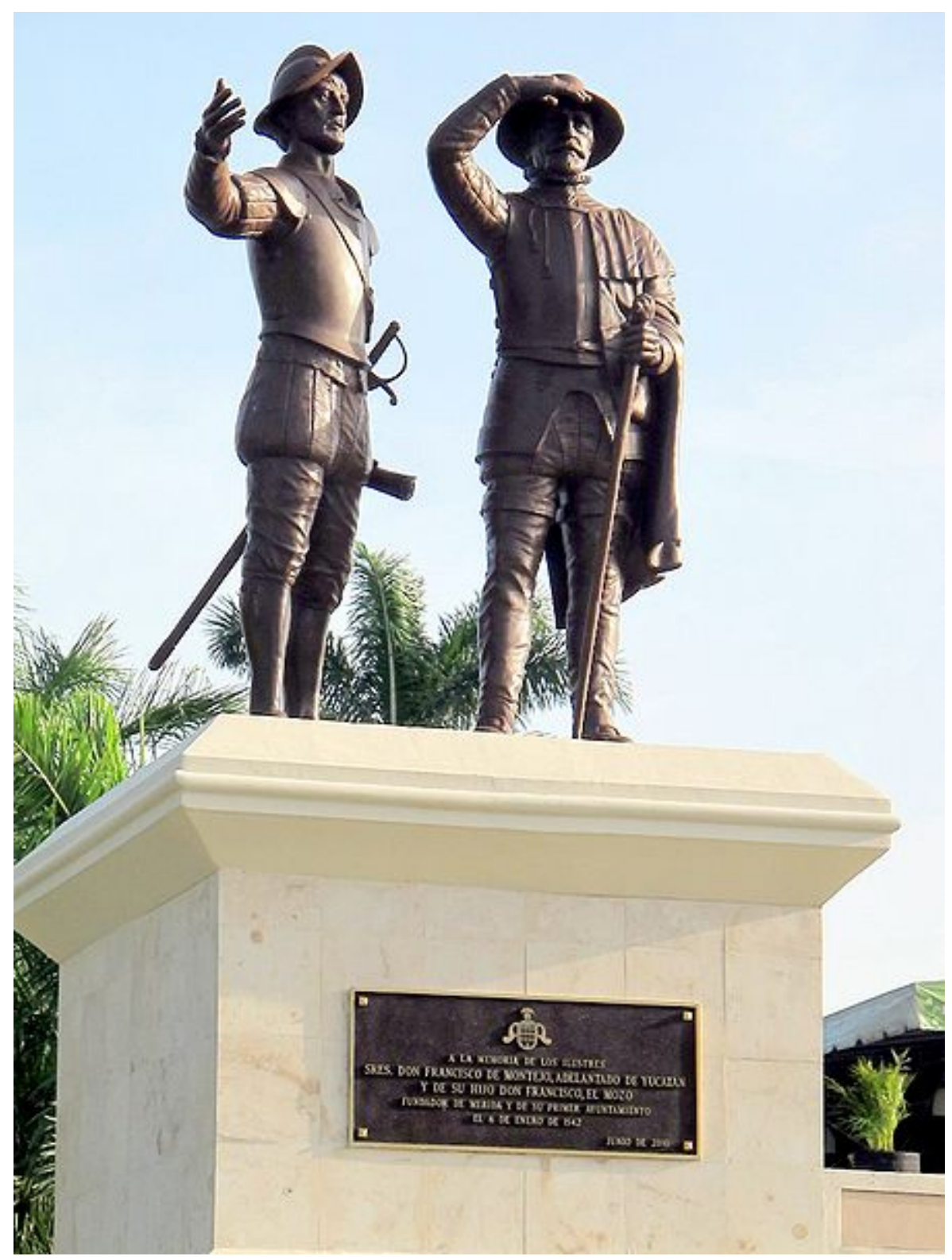

Imagen 3. Las estatuas de los Francisco de Montejo (imagen tomada de Wikipedia) 


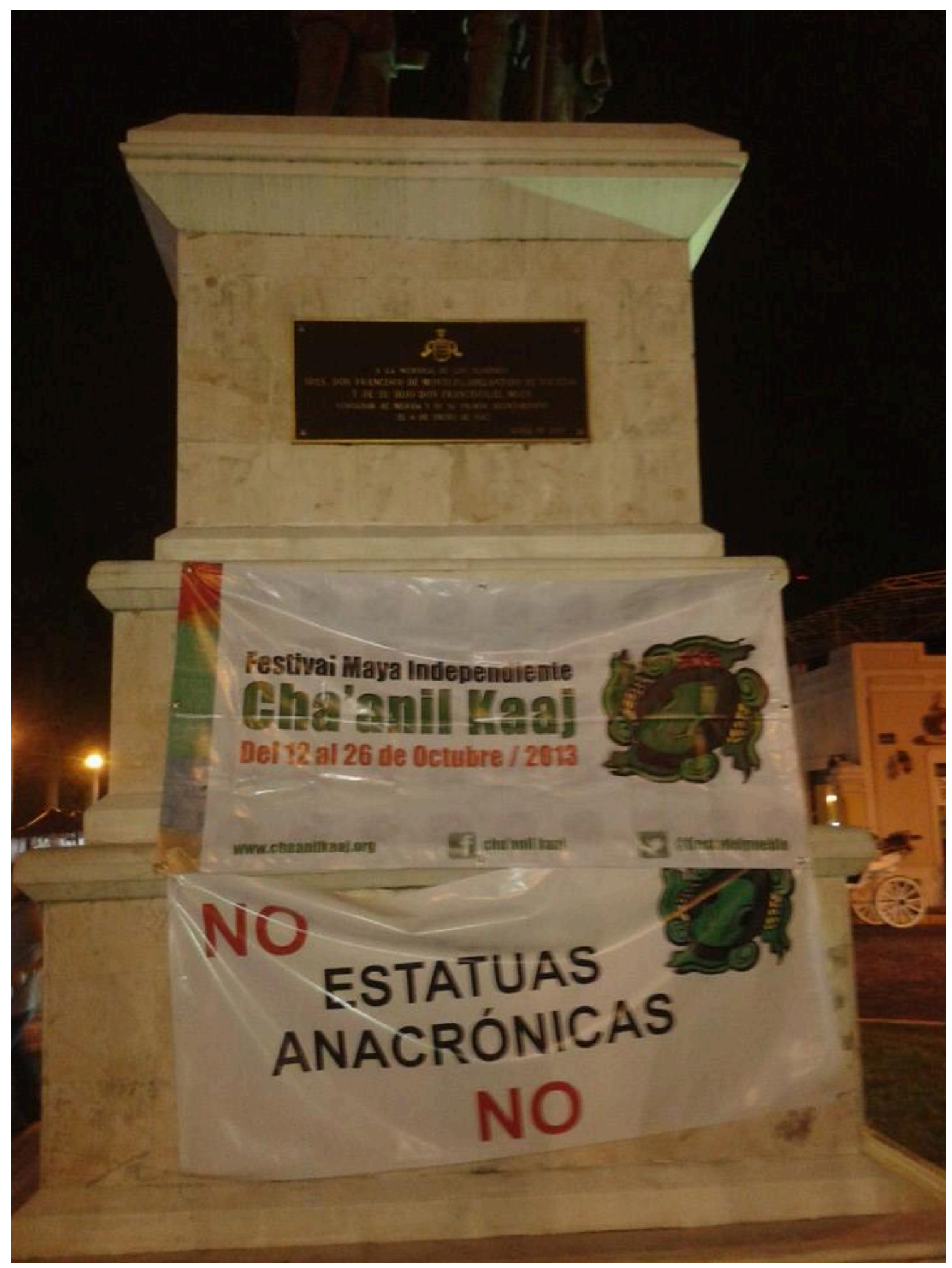

Imagen 4. Protesta ante las estatuas (foto tomada por el autor) 
Otro acto considerado convencionalmente político fue la redacción de una carta que fue publicada en el Diario de Yucatán. La misiva estuvo dirigida a Rigoberta Menchú, Joaquín Sabina, Joan Manuel Serrat, quienes participaron en el FICM, a los "Señores y señoras artistas e intelectuales que participan en el Festival Internacional de la Cultura Maya del Gobierno del estado de Yucatán”, al "Pueblo Maya de Yucatán”, a los "Pueblos de México" y los "Pueblos del mundo". En la carta, publicada en uno de los periódicos más leídos del estado y la región, los autores se refieren primero a "dos festivales que usan el nombre de la cultura de la que es heredero el pueblo maya yucateco de hoy" y denuncian que, en el FICM, "los intelectuales, artistas y miembros del pueblo maya fuimos primero excluidos y luego ignorados". Posteriormente, exponen que "prestigiados intelectuales y escritores mayas y personas que admiran a ese pueblo y su cultura decidieron hacer un festival alternativo", el cual "se hace con recursos propios de las organizaciones y personas que lo impulsan y con elementos que no se compran ni venden: sentido comunitario, solidaridad, imaginación, creatividad, honradez, coraje, valor y perseverancia". En la carta también se hace referencia al "mal gobierno del estado de Yucatán", sobre el cual mencionan: "Estamos seguros que entre los artistas e intelectuales que participarán en el festival que organiza el mal gobierno hay personas buenas, honradas y sensibles que sabrán reconocer el llamado de los mayas yucatecos que no piden limosna, sino justicia, que no piden migajas sino el pleno reconocimiento de su valor como pueblo y cultura".

En todos estos casos podemos apreciar, con Derrida y Butler, que ciertos discursos, como el de la crítica al colonialismo, el de los derechos humanos y derechos indígenas, de la autonomía y del reconocimiento, son repetidos, lo cual es una fuente de su fuerza performativa.

\section{Conclusiones}

En este capítulo hemos visto tanto la dimensión performativa de la etnicidad (la etnicidad como performance), así como una serie de performances étnicas. En ambos casos, quienes llevan a cabo dichas prácticas se encargan de dar existencia performativa al "pueblo maya" y de la reivindicación del mismo. Si bien desde ciertos registros (sociales, históricos, demográficos, étnicos) uno puede poner en duda la existencia de un "pueblo 
maya", Cha'anil Kaaj, al presentarse como el festival del pueblo maya, le da existencia performativa.

Si tomamos en cuenta el carácter inacabado de la realidad sociocultural (Bloch 1980; Krotz 2004c), la etnicidad maya, como todo fenómeno, dista de ser algo que simplemente ya está dado; además de ser una construcción histórica, se actualiza con las prácticas, que siempre son contingentes, siempre pueden ser de otra forma. En este orden de ideas, la etnicidad maya, tal como es desplegada por Yóol Kaaj y Cha'anil Kaaj, no ha asumido un carácter beligerante; sus demandas tampoco se han centrado en las tierras u otros recursos materiales; más bien, en una actitud explícita de no confrontación con el gobierno (ya sea porque busca su colaboración o apuesta por una autonomía con respecto a él), ha seguido centrada en la demanda por el reconocimiento del "pueblo maya", de su diferencia cultural y, sobre todo, de la lengua maya.

Además de enfocarme en las prácticas de la etnicidad, al centrarme en la etnicidad como performance también he descrito cómo los actores son presentados, cómo quieren ser vistos por otros. Cha'anil Kaaj presenta al pueblo maya como uno con fuertes raíces históricas pero vivo y contemporáneo, cuyas formas de organización son comunitarias y horizontales. Del mismo modo, el análisis de la etnicidad como performance enfatiza cómo dichas prácticas performativas, al realizarse en las circunstancias adecuadas, contar con autoridades y repetir discursos, "hacen cosas". En este caso, me parece que una de sus principales acciones es darle existencia performativa al pueblo maya, un pueblo maya que existe en oposición al "mal gobierno". En realidad, o por lo menos en otro nivel de la realidad, podemos apreciar que no existe tal oposición entre gobierno y pueblo maya; en la organización y realización del festival pudimos apreciar distintas colaboraciones entre actores pertenecientes a ambas categorías; es sólo en un nivel preformativo que existe dicha oposición.

¿Qué nos dice el análisis de Yóol Kaaj y Cha’anil Kaaj sobre la relación entre etnicidad y poder? Retomando la propuesta del capítulo teórico de esta tesis, podemos reconocer dos dimensiones de análisis: el control de recursos significativos y los órdenes clasificatorios hegemónicos (dimensiones que, cabe destacar, sólo son distinguibles en términos analíticos). 
En cuanto al control de recursos, lo primero que hay que advertir es que, con Cha'anil Kaaj, Yóol Kaaj no pretendía "tomar el poder" ni incorporarse a las instituciones gubernamentales. Cha'anil Kaaj presenta una crítica al gobierno del estado y al uso del nombre "maya" como un recurso. Así, una de las propuestas de Yóol Kaaj, que aún no ha llegado a formalizarse, es que ya no se use más el nombre "maya" en actividades que no incluyen a los mayas. Ciertamente, se trata de una demanda compleja, pues implica que existen identidades (mayas y no mayas) claramente reconocibles, cuando, como ya se ha visto, el escenario identitario étnico del estado es mucho más complejo. Sin embargo, existe la posibilidad de que dicha demanda siga siendo planteada y que se lleve a una propuesta de ley.

También cabe otra posible lectura en cuanto al control de los recursos. Tal vez sin proponérselo, para la organización de Cha'anil Kaaj los integrantes de Yóol Kaaj han movilizado recursos provenientes de distintos ámbitos: se han retomado y creado relaciones y vínculos con distintas organizaciones e instituciones (los integrantes de Yóol Kaaj hablaban de "tejer redes"; desde otro registro se podría hablar de la construcción de un "capital social”), así como recursos materiales (provenientes del gobierno — como un proceso de delegación de poder-, organizaciones no gubernamentales — procesos de coordinación de poder-, donadores independientes) y simbólicos. Cabe destacar que los recursos obtenidos del ámbito gubernamental provinieron de los partidos opositores al gobierno estatal, es decir, del PAN (partido que gobierna el municipio de Mérida) y del PRD. En este sentido, es posible que Yóol Kaaj participe en futuras actividades realizadas por cualquiera de esos dos partidos, tema que ha sido controvertido dentro de la organización, pues mientras que algunos ven en la colaboración una forma viable de lograr sus cometidos, otros, afines al EZLN, apuestan por la vía autónoma. De hecho, después de la realización de Cha'anil Kaaj, diversos integrantes de Yóol Kaaj participaron en La Escuelita zapatista, en Chiapas, y a partir de esta experiencia han reafirmado los principios zapatistas en la organización de Yóol Kaaj. ${ }^{165}$

\footnotetext{
${ }^{165}$ No debe pensarse que en Yóol Kaaj sólo existen estas dos oposiciones (la que contempla la colaboración con el gobierno y la que apuesta por la autonomía). Así, en Yóol Kaaj encontramos diversas posiciones. Además de las ya referidas, desde quienes consideraban que el festival era una forma de conservar el patrimonio cultural, las tradiciones y las costumbres, hasta quienes consideraban que era una forma de expresar y disfrutar las manifestaciones artísticas del pueblo maya. Por ejemplo, para uno de los integrantes, Cha'anil Kaaj es "un legítimo festival sin fines de lucro, que nace del pueblo maya y da el
} 
Con respecto a los órdenes clasificatorios hegemónicos, la celebración de Cha'anil Kaaj plantea una crítica explícita al orden clasificatorio hegemónico que conceptualiza a la cultura maya de una manera alocrónica y mercantil. En contraparte, Cha'anil Kaaj presenta nuevas formas de indigeneidad, de ser mayas "vivos" y “contemporáneos". Aquí cabe recordar con Paul Rabinow (2007) que lo "contemporáneo" no alude únicamente a lo nuevo, sino a las diversas mezclas entre el pasado y lo que emerge. En este orden de ideas, Yóol Kaaj reivindicaba los principios de organización comunitarios y tradicionales, pero los vinculaba con los postulados zapatistas de autonomía y de horizontalidad de nuevos movimientos sociales. Del mismo modo, en el festival tuvieron cabida actividades consideradas "tradicionales", pero los modos de organización, así como de cobertura de dichas actividades, implicaron un constante uso de nuevas tecnologías de información y comunicación, por ejemplo, la elaboración de una página electrónica para el festival, la presentación del proyecto en un video en YouTube, el uso de Facebook para la organización y difusión de los eventos, la transmisión de las actividades a través de streaming, entre otros. En este sentido, es una muestra notable de las nuevas formas de subjetividad y de indigeneidad defendida por varios jóvenes mayas, en las que ser maya puede significar preservar la tradición a través de nuevas tecnologías. Sobre estos actores trata el siguiente capítulo.

lugar que corresponde a artistas, escritores, músicos, poetas, terapeutas, artesanos, videastas, entre otros creadores mayas; así como a estudiosos locales de la lengua y la cultura maya. Así se quiere llegar al pueblo maya y que puedan disfrutar de sus expresiones artísticas y culturales", mientras que el colectivo Yóol Kaaj tiene como "principal objetivo [...] salvaguardar el patrimonio cultural maya: tangible o intangible y material o inmaterial” (Güémez 2013). 


\section{LA EMERGENCIA DE JÓVENES MAYAS: LA LITERATURA Y LAS NUEVAS TECNOLOGÍAS COMO ARENAS DE REIVINDICACIÓN ÉTNICA}

"La pérdida de la lengua maya entonces debe interesar sobre todo a nosotros, los mayas, quienes venimos de abuelas y abuelos que nos contaron cómo y en qué tiempo son las cosas, debe interesar a quienes respetamos a los montes y pedimos permiso para sembrar y quemar, quienes agradecemos la lluvia, quienes sabemos que la lengua nos da poder, nos da fuerza y que cada estructura de ella es un universo simbólico que debemos transmitir a quien desconoce, porque más allá de la maravilla mundial de Chichén, la lengua es nuestro bien más preciado, el tesoro que nos puede enseñar astronomía, biología, historia, filosofía y medicina” Yazmín Novelo (joven comunicóloga maya) "Lengua maya amenazada"

En términos históricos, uno de los primeros campos en donde se manifestaron las reivindicaciones del Pueblo Maya fue el campo jurídico. Como vimos en el capítulo 4 de esta tesis, en 2007 se llevó a cabo una modificación a la Constitución del Estado para reconocer que Yucatán tiene una "composición pluricultural sustentada originalmente en el pueblo maya" y en 2011 se decretó la controvertida "Ley para la Protección de los Derechos de la Comunidad Maya del Estado de Yucatán”. Las limitaciones de dicha Ley, expuestas en páginas anteriores, no han sido obstáculo para que los actores que reivindican al Pueblo Maya sigan haciendo alusión a los derechos humanos de los pueblos indígenas y a instrumentos como el Convenio 169 de la OIT. Tal es el caso del Festival Maya Independiente Cha'anil Kaaj, celebrado en 2013, cuyo objetivo era visibilizar y reivindicar al Pueblo Maya vivo y contemporáneo, en contraste con el 
Festival Internacional de la Cultura Maya celebrado por el Gobierno del Estado que tenía como motivo a la cultura maya antigua.

Tanto en el caso del campo jurídico como del festivo, uno de los objetivos centrales en las reivindicaciones del Pueblo Maya era la reivindicación de la lengua maya: su defensa, conservación, revitalización y actualización. Esta demanda ha sido asumida en años recientes por un conjunto de jóvenes que se autoidentifican como mayas. En este capítulo analizaré los proyectos y acciones que dichos jóvenes mayas están llevando a cabo para reivindicar al Pueblo Maya; particularmente, estudiaré dos arenas en las que están en juego la preservación y transformación de la lengua maya: la literatura y las nuevas tecnologías de información y comunicación. El orden de la exposición es el siguiente. En un primer apartado plantearé algunos elementos de investigaciones y discusiones recientes en torno a los jóvenes indígenas en México. Como se podrá ver, uno de los puntos centrales de discusión es la emergencia y transformación de la categoría "joven” en las poblaciones indígenas. En el segundo apartado presentaré el estado de la cuestión, ciertamente incipiente, de los estudios sobre juventud maya en Yucatán, así como algunos datos generales sobre jóvenes mayas en la ciudad de Mérida. Los apartados tercero y cuarto están dedicados a dos arenas donde han sido notables los proyectos y acciones de los jóvenes mayas: la producción literaria y las nuevas tecnologías de información y comunicación. En este sentido, retomo uno de los desafíos observados por Jean Jackson y Kay Warren (2005) en su revisión sobre los movimientos indígenas latinoamericanos entre 1992 y 2004: la emergencia de un activismo indígena joven, con características distintas a los primeros intelectuales indígenas. En las líneas que siguen veremos si, como han advertido Marisol de la Cadena y Orin Starn (2009), los emergentes jóvenes indígenas ya no se interesan tanto en las viejas demandas sobre derechos a la tierra y organización política tradicional, y si buscan en cambio otras formas de afirmación y de construcción de identidades.

\section{Jóvenes indígenas: ¿una categoría emergente?, ¿una problemática específica?}

Los jóvenes indígenas, en cuanto jóvenes e indígenas, han sido actores poco conocidos en las etnografías de México. No obstante, en años más recientes se puede advertir un creciente interés teórico y etnográfico sobre ellos. Esto se puede deber, en primer lugar, 
al peso demográfico de dicho sector y a que, en términos generales, México puede ser considerado un país de jóvenes. Asimismo, la migración rural-urbana al interior del país, así como el incremento de las escuelas públicas en todo el territorio nacional, ha aumentado la visibilidad de los jóvenes indígenas tanto en ciudades, zonas conurbadas y zonas rurales. Del mismo modo, los jóvenes son considerados actores clave en el cambio cultural así como en la producción cultural creativa, tanto en poblaciones indígenas como no indígenas (Pérez Ruiz 2011a:66; Urteaga 2011:256, 259, 261). Por último, también podemos advertir que en algunos movimientos y organizaciones indígenas de años recientes (desde el Ejército Zapatista de Liberación Nacional en el sur de México hasta el Idle No More en Canadá), los jóvenes han jugado un papel notable.

En este contexto, especialistas en juventud han comenzado a investigar el tema de las juventudes indígenas en su especificidad tanto etaria como étnica. Una de las cuestiones teóricas y etnográficas centrales que se ha planteado es si en los grupos indígenas estudiados existe o no una categoría que se refiera a la etapa de juventud. Al respecto, la antropóloga Maritza Urteaga (2011) ha advertido que, por lo general, en los grupos indígenas de México sus integrantes pasan de la niñez a la etapa adulta a través de la incorporación al trabajo o por medio del matrimonio. Es hasta décadas más recientes, argumenta Urteaga, que el crecimiento de las escuelas públicas, la acentuación de la migración y la mayor presencia de los medios masivos de comunicación, que ha emergido la categoría de jóvenes indígenas en el país. En este orden de ideas, podemos preguntarnos: ¿existe entre la población maya hablante de Yucatán la categoría "joven” (o alguna similar)? O, mejor, ¿existen en Yucatán jóvenes mayas?

Al respecto, la antropóloga Maya Lorena Pérez Ruiz (2011a:65), una de las pioneras en el campo de investigación de jóvenes indígenas, ${ }^{166}$ ha planteado que:

los jóvenes no sólo existen como un sector identificable y diferenciado entre los indígenas, sino que son un sector clave en ámbitos rurales y urbanos, porque en ellos se expresan con nitidez los conflictos y las disyuntivas sobre el cambio y la continuidad de sus grupos culturales, así como el impacto de los medios masivos de comunicación y el consumo de bienes culturales.

${ }^{166}$ Maritza Urteaga (2011:279) se refiere a ella como "la primera antropóloga que pregunta por la especificidad juvenil migrante indigena en las ciudades". 
Para el caso particular de Yucatán, Pérez Ruiz (2011b:93) argumenta que "los jóvenes son un sector de la población diferenciado que ha existido desde tiempos remotos" (al menos desde las primeras décadas del periodo colonial, como se puede apreciar en los escritos de Fray Diego de Landa), y que existen términos en maya yucateco para nombrar a las y los jóvenes. Por ejemplo, el Diccionario Maya: Maya-Español Español-Maya registra el término $X$-chu'pal para "muchacha" y Tan icha-mil para mocetona en edad casadera (Barrera Vásquez 2001:737, 937). Asimismo, el mismo diccionario da cuenta que Ah Mun quiere decir "literalmente 'tierno', nombre del joven dios del maíz, también significa fruta o cosecha tierna, pudiendo ser igualmente utilizado para un adolescente" (Barrera Vásquez 2001:541) y que la voz Pal significa "mozuelo", "mozo que no es casado, mozo, mancebo, joven, muchacho, niño" (Barrera Vásquez 2001:627). ${ }^{167}$ Como se puede apreciar, en estos casos, la categoría joven alude sobre todo a una persona que ya está en edad para contraer matrimonio.

En este punto, cabe traer a colación una de las advertencias formuladas por Pérez Ruiz (2011a:73) con respecto al estudio de las juventudes indígenas, a saber, que la investigación de estas últimas sea "algo más que la mezcla arbitraria entre la temática de 'lo joven en general', [y] de lo 'étnico e indígena en general'”. En otras palabras, ¿qué problemas singulares nos plantea la categoría específica de jóvenes indígenas? En primera instancia, debemos reconocer las vías a través de las cuales uno llega a estudiar dicha temática. Pérez Ruiz (2011a:66) señala tres: quienes ya trabajaban con poblaciones indígenas y la problemática étnica y se han orientado hacia el estudio de los jóvenes indígenas pero sin poseer una teoría acerca de la juventud; quienes provienen de los estudios culturales y urbanos y han indagado culturas e identidades juveniles, pero que carecen de una teoría sobre lo étnico; y quienes se han planteado específicamente el estudio de los jóvenes indígenas y suelen ser nuevos tanto en la problemática indígena como en la de jóvenes. Yo comencé estudiando la problemática étnica maya, y fue solamente durante el trabajo de campo, cuando algunos entrevistados me sugirieron hablar con "jóvenes mayas", que empecé a explorar la temática. En este orden de ideas, metodológicamente nunca planteé trabajar con jóvenes, pero a continuación deseo

\footnotetext{
${ }^{167}$ Asimismo, Pérez Ruiz (2011a:71) documenta que en Yaxcabá, el término maya chu'palech alude a "muchacha" y a la idea de que la muchacha está en peligro y genera peligro; del mismo modo, la expresión taankelem paal refiere a los que ya tienen fuerza en sus hombros.
} 
destacar algunos elementos teóricos que me parecen relevantes para el análisis de los jóvenes mayas y sus reivindicaciones étnicas.

Una de las notas constitutivas de la antropología de la juventud es que esta última no es una condición natural, sino una "construcción cultural" (Feixa 1998:18). Pero como ha propuesto Carles Feixa (1998:11) en un libro fundacional de la especialidad, la antropología de la juventud no sólo debe ocuparse de la construcción cultural de la juventud, sino también de "la construcción juvenil de la cultura (es decir, de las formas mediante las cuales los jóvenes participan en los procesos de creación y circulación culturales)". Esta segunda ruta nos conduce a prestar mayor atención a la "capacidad creativa y no solamente imitativa de los jóvenes" (Feixa 1998:11). En este sentido, no sólo debemos preguntarnos si la noción de jóvenes mayas es o no una construcción cultural, sino también cómo participan los jóvenes mayas en los procesos de producción cultural, particularmente, en el caso de esta investigación, de las reivindicaciones del Pueblo Maya.

De este modo, en este trabajo me centraré en la producción cultural de los jóvenes mayas, tomando en consideración que la agencia de los actores siempre se encuentra condicionada, aunque no necesariamente determinada, por los elementos estructurales de la sociedad (Bourdieu 2009; Giddens 2006; Ortner 1984). Sin embargo, debemos tomar en cuenta que un énfasis descuidado en la agencia de los jóvenes puede conducirnos a una "imagen sublime" de la juventud (Díaz Cruz 2002b:21), por ejemplo, a la idea de que con sus obras literarias o sus usos de la tecnología, los jóvenes mayas resisten todo poder. ${ }^{168}$ Por lo tanto, hay que partir más bien de la multiplicidad y heterogeneidad de las prácticas culturales juveniles.

Otro elemento teórico y metodológico sugerente para la indagación de las juventudes indígenas es focalizar nuestra atención en las "zonas de frontera", aquellos sitios de producción cultural creativa definidos entre comunidades relativamente homogéneas (Urteaga 2011:259). Como sostiene Urteaga (2011:261), la juventud indígena puede ser considerada una zona fronteriza, esto es "como espacio sociocultural en construcción (en proceso) y como una 'intersección transitada', emplazada 'dentro y

\footnotetext{
168 Desde luego, tampoco debemos sucumbir en otro peligro, concebir a los jóvenes desde imágenes de bajeza (Díaz Cruz 2002:21).
} 
entre' los ámbitos rurales y urbanos". A la idea de "zona de frontera" cabe añadir las de "fricción", tal como fue trabajada por Anna Tsing (2005) en su magnífica etnografía sobre la interconexión global en Indonesia, así como la ya citada teoría de Cardoso de Oliveira (1963) sobre la "fricción interétnica". De acuerdo con Tsing, las zonas de fricción resultan metodológicamente clave para entender procesos de negociación y disputa de significados de categorías de clase, etnia, género, de identidad, de nacionalidad, de estética, entre otras. En contextos como el latinoamericano — tal como observó Cardoso (1963)—, destacan las tensiones entre distintos grupos étnicos. Hay que advertir también que las zonas de frontera son de carácter liminal y marginal y, como formuló Victor Turner, en tanto tales, constituyen espacios de gestación de nuevos símbolos, metáforas y comparaciones (Díaz Cruz 2002:32-34), los cuales contribuyen a transformar órdenes clasificatorios hegemónicos que sustentan las estructuras sociales (ver Pérez Ruiz 2011a).

Así, una de las problemáticas específicas (aunque no necesariamente exclusivas) de los jóvenes indígenas es su situación fronteriza o liminal entre el cambio y continuidad con sus culturas de origen. Desde luego, hay que advertir que la noción de jóvenes indígenas es sumamente heterogénea y que la situación de cambio y continuidad varía de acuerdo con dicha heterogeneidad. No es lo mismo ser un joven maya hablante campesino en una comunidad rural en el oriente del estado de Yucatán, que una joven maya hablante del sur de dicha entidad que ha emigrado a la ciudad de Mérida para emplearse como trabajadora doméstica o que un joven maya hablante que se identifique como maya y que haya ascendido en la escala socioeconómica en la misma ciudad de Mérida. Sin embargo, como se puede apreciar a partir de estudios sobre el tema (ver Guzmán Medina 2010; López Santillán 2011; Pérez Ruiz 2011b), en todos ellos aparece el problema entre la continuidad y el cambio con las normas, valores, prácticas, creencias y símbolos de generaciones mayores de sus comunidades de origen. En términos generales, los estudios han notado que los jóvenes indígenas se ven menos acotados por las prescripciones culturales de sus comunidades de origen; asimismo, se ha enfatizado su papel como agentes de cambio. No obstante, las formas de continuidad y de cambio, insisto, no son homogéneas, y una tarea de la investigación es elucidar de qué manera ocurren dichos procesos. En este trabajo me centraré en jóvenes que se autodefinen como 
mayas, radicados principalmente en la ciudad de Mérida, y que están llevando a cabo proyectos y acciones para reivindicar su cultura y su pueblo.

\section{Jóvenes mayas en Yucatán}

2.1 Estudios sobre jóvenes mayas en Yucatán: marginación, desigualdad y nuevas formas de ser joven

Como he señalado más arriba, comencé a trabajar con jóvenes mayas porque algunas de las personas que entrevisté durante la fase inicial del trabajo de campo me recomendaron hablar con jóvenes. Por lo tanto, no partí de un rango de edad para elegir a las personas entrevistadas, más bien, al final de mis entrevistas y charlas informales, siempre pregunté con quién más me recomendaban hablar, y muchas de las personas recomendadas fueron jóvenes. Este hecho, como destacaré más adelante, me sirvió también para trazar una red de actores mayas.

Al igual que los jóvenes indígenas en México, los jóvenes mayas en Yucatán apenas comienzan a ser protagonistas de las etnografías y las investigaciones sociales. Más que hacer un repaso bibliográfico del estado de la cuestión, me interesa destacar algunos datos y materiales para esbozar el contexto en el que los jóvenes mayas con quienes he trabajado están llevando a cabo sus reivindicaciones étnicas.

Uno de los trabajos pioneros sobre el tema es el proyecto de investigación "Estrategias mayas de combate a la marginación. La juventud indígena y los programas sociales de salud, educación, trabajo y tiempo libre”, dirigido por Mariano Báez Landa (2007), del Centro de Investigaciones y Estudios Superiores en Antropología Social (CIESAS), y a partir del cual se produjo un video titulado Juventud maya. Problemas y retos en Yucatán. El video, de una duración de 23:42 minutos, nos muestra a una docena de jóvenes de distintos municipios de Yucatán, la diversidad de sus actividades laborales (que van desde locutora de radio a la industria de la construcción, pasando por cocineros en puestos de comida, trabajadoras en maquiladoras y chóferes de camión), así como de sus prácticas culturales (desde el breakedance hasta el futbol femenil). El video da cuenta también de las diferencias en creencias, normas y valores, por ejemplo, desde el caso de una joven que reconoce que la pueden considerar "antigua" porque cree que se debe llegar virgen al matrimonio, hasta jóvenes solteras cuya mayor expectativa no es casarse 
sino finalizar sus estudios y conseguir un empleo y que piensan que tener relaciones sexuales premaritales no es malo si se tiene el cuidado necesario. Pero un punto en común es que casi todos subrayan la falta de oportunidades en sus comunidades de origen, a las cuales también consideran como más "cerradas", reticentes al cambio, como se puede apreciar en las creencias de que sólo los varones merecen educación. Por último, hay que notar que en estos jóvenes no aparece explícitamente la problemática étnica (en el sentido de reivindicación étnica, identidad étnica u orgullo étnico). Sólo una joven expresa su deseo de "aprender perfectamente la maya" y realizar un proyecto en los Estados Unidos para fomentar la cultura maya.

La relación entre juventud maya y el problema de pobreza y marginación en Yucatán también ha sido estudiado por la antropóloga Violeta Guzmán Medina (2010), quien se ha enfocado particularmente en los problemas de salud de dicho sector. Guzmán (2010:128) indica que si bien no trabaja la "problemática de la juventud per se, sí podemos plantear que existen problemas sociales que impactan de forma más aguda y grave a la juventud, por su especial posicionamiento en la sociedad occidental contemporánea". De este modo, Guzmán parte del contexto del capitalismo contemporáneo, las políticas de ajuste macroeconómico y de la precarización de las condiciones del empleo para destacar tres problemas sociales que impactan a la juventud maya en 14 municipios de alta y muy alta marginalidad en Yucatán: 1) las patologías de tipo laboral, "especialmente entre los migrantes pues la mayoría de estos jóvenes se insertan en la albañilería como actividad productiva"; 2) las adicciones; y 3) problemas y enfermedades de transmisión sexual (Guzmán 2010:130). Cabe destacar que los jóvenes migrantes "sufren un grave problema de exclusión en materia de seguridad social", pues no sólo se insertan en los empleos menos calificados y de más baja remuneración, sino que carecen de prestaciones sociales y se encuentran en condiciones laborales poco salubres (que van desde jornadas laborales de diez a doce horas hasta la exposición al sol que provoca enfermedades de la piel, del aparato respiratorio y de los ojos) (Guzmán 2010:131). Asimismo, la mayoría de los jóvenes encuestados y entrevistados no tiene una idea precisa de las enfermedades de transmisión sexual, mucho menos de las maneras de protegerse de ellas (Guzmán 2010:132). Por último, Guzmán advierte también el alarmante problema del incremento del alcoholismo, especialmente entre migrantes, así 
como el hecho de que las acciones gubernamentales sobre la prevención de adicciones no consideren el consumo de alcohol como una droga (Guzmán 2010:133).

Quien ha explorado la relación entre los jóvenes mayas y la problemática étnica en Yucatán ha sido la antropóloga Maya Lorena Pérez Ruiz (2011b). En su investigación realizada en Yaxcabá, en el oriente del estado, Pérez Ruiz ha mostrado cómo la reciente movilidad ascendente (gracias a la escolaridad y a la migración) de los jóvenes mayas está cuestionando el sistema interétnico dominante en la localidad, el cual se expresa de manera notable en el prestigio de los apellidos españoles sobre los mayas, así como en las elecciones matrimoniales. ${ }^{169}$ En palabras de Pérez (2011b:88), estos jóvenes mayas se han atrevido a "confrontar el prestigio de los pobladores de apellido español, y hasta a violentar la prohibición de casarse con alguien de ese grupo". Asimismo, ha identificado tres formas de ser joven maya en Yaxcabá: 1) los jóvenes campesinos, que permanecen vinculados a las actividades agropecuarias así como a las prácticas de trabajo y cultura tradicionales; 2) los jóvenes asalariados, que han optado por el trabajo migratorio como principal forma de vida; y 3) los jóvenes estudiantes, que han llegado hasta el bachillerato y tienen expectativas de continuar sus estudios fuera de Yaxcabá (Pérez Ruiz 2011b:95). Todos están viviendo un importante proceso de cambio, pero para cada tipo de joven los marcos de oportunidades para realizar sus expectativas son muy distintos, pues "continúan actuando sobre ellos los marcadores étnicos que los mantienen en grupos diferenciados cultural, social y económicamente asimétricos” (Pérez Ruiz 2011b:101). Del mismo modo, mientras que en algunos casos las nuevas maneras de ser joven debilita la diferenciación étnica, en otros ésta se acentúa. Pero, en términos generales, las nuevas maneras de ser joven en Yaxcabá, asociadas con la independencia, la originalidad, la individualidad y la libertad, implican una distancia con el "mundo anterior, de las generaciones de los adultos" (Pérez Ruiz 2011b:92).

Quiero destacar un aspecto teórico y etnográfico del trabajo de Pérez Ruiz. Ella argumenta que, desde la Conquista, existe en Yucatán un sistema de relaciones interétnicas (los indios/macehuales/mayeros/milperos son inferiores, mientras que los blancos/vecinos son superiores) que ha determinado el acceso diferenciado a los recursos

\footnotetext{
169 Pérez Ruiz reporta que en Yaxcabá tanto el vestido como, en menor medida, la lengua maya, están perdiendo importancia como marcadores étnicos.
} 
naturales y sociales. En términos de poder, podemos decir que un determinado orden clasificatorio hegemónico ha condicionado el control de los recursos culturalmente significativos. En este orden de ideas, en lo que sigue analizaré cómo los jóvenes mayas, con sus reivindicaciones étnicas, se relacionan con dicho sistema de poder, entendido tanto en su dimensión de control de recursos como de órdenes clasificatorios hegemónicos. Pero antes presentaré algunos datos generales sobre la juventud maya en Mérida.

\subsection{Jóvenes mayas en la ciudad de Mérida}

Como han señalado Urteaga (2011) y Pérez Ruiz (2011a y 2011b), la migración es uno de los fenómenos que más ha contribuido a la emergencia de nuevas maneras de ser joven indígena. En este apartado me detendré en una red de actores jóvenes que se autodefinen como mayas que están gestando nuevas formas de ser jóvenes mayas y que están impulsando proyectos de reivindicación de su pueblo. En su mayoría, son jóvenes que han migrado, especialmente en búsqueda de mejores condiciones de vida. Hay que tener en cuenta que, como ya ha observado Ariel García Martínez (en Urteaga 2011:264), la educación escolar y la migración se han constituido en recursos para lograr un mejor espacio y una posición mejor que sus condiciones de origen. Es decir, han constituido una forma de poder, que distingue a estos jóvenes de quienes sufren la marginación y exclusión a las que se hizo referencia al inicio de este apartado. No obstante, esto no significa que estos jóvenes no se encuentren en una situación de incertidumbre, a una condición que ha sido caracterizada como de "supervivencia" (Abèlés 2008; García Canclini 2008). Algunos datos podrán darnos una idea de la situación en desventaja de los jóvenes maya hablantes (y de la población maya hablante en general) en la ciudad de Mérida, una ciudad que, a nivel estatal (e incluso peninsular), concentra escuelas, establecimientos de educación superior, centros de salud y empresas industriales o de bienes y servicios, pero que también está notablemente segregada, en donde los mejores servicios se encuentran en el norte de la ciudad, y las zonas oriente, poniente y sur poseen servicios de mala calidad o incluso carecen de ellos.

De acuerdo con el Conteo de Población del Instituto Nacional de Estadística y Geografía (INEGI) en 2005, en la ciudad de Mérida residen 64358 hablantes de lengua 
maya (Lizama Quijano 2012:14). Según la tipología de municipios con presencia indígena elaborado por la Comisión Nacional para el Desarrollo de los Pueblos Indígenas (CDI), el de Mérida es "tipo C", es decir, “de aquéllos cuya población hablante de lengua indígena no supera el $40 \%$ respecto al total municipal, por lo que han sido llamados como "municipios con presencia indígena"' (Lizama 2012:15). Un problema que se plantea en este tipo de municipios es que en ellos "la lengua [maya, en este caso] no puede ser empleada en todos los contextos" (Lizama 2012:16).

Hay que advertir, como lo ha hecho el antropólogo Jesús Lizama (2012), que la presencia maya hablante en Mérida no es un fenómeno nuevo, sino que se remonta a la fundación misma de la ciudad. Del mismo modo, si bien la migración rural-urbana tampoco es un fenómeno exclusivo de los últimos años, es hasta fechas recientes que se ha intensificado de manera notable. Y aquí hay que tener en cuenta que "quienes en su mayoría no tienen a la milpa como principal ocupación son los jóvenes”, y, por lo tanto, son ellos quienes "han comenzado a considerar la migración como su único camino para allegarse de recursos con los cuales satisfacer sus diferentes necesidades" (Lizama 2012:19).

En 2008, el CIESAS Peninsular aplicó la Encuesta sobre migrantes permanentes mayas en la ciudad de Mérida (Enmimérida), en colonias periféricas ubicadas en el sur y oriente de la ciudad (Lizama Quijano 2012). Los datos obtenidos en la encuesta nos pueden ser de utilidad para hacernos una idea de la situación de los jóvenes maya hablantes en dichas zonas de la ciudad.

En cuanto a la situación lingüística de los encuestados, si bien la mayoría $(55.43 \%)$ no habla la lengua maya, un 69.15\% afirmó entenderla. Sin embargo, muy pocos $(1.07 \%)$ dijo saber leerla y unos menos $(0.60 \%)$ afirmaron poder escribirla (Lizama 2012:119). Si desglosamos los datos por grupos de edad, encontramos que el mayor número de hablantes de lengua maya (136 en números absolutos, el 20.33\% de la muestra) se encuentra en el rango 45-54; le sigue el rango 55-64, con un total de 133 mayahablantes (el 19.88\% de la muestra). Las cifras bajan significativamente en el rango de edad 25-34 (74 mayahablantes, el 11.06\% de la muestra) y aún más en el rango 15-24 (26 mayahablantes, 3.89\%). Asimismo, la mayoría de las personas que declararon saber leer y escribir en lengua maya se encuentran en los rangos de edad que van de los 35 a los 
64 años (Lizama 2012:120). Es decir, según la Enmimérida, los jóvenes son quienes menos hablan la lengua maya y quienes menos saben leerla y escribirla.

Sobre la identidad étnica, resulta interesante que ningún jefe de familia de 15 a 34 años se haya autoadscrito como "Maya", "Indígena", "Indio", o "Mestizo". Sólo una persona de 15 a 24 años, y otra de 25 a 34 años, se autoidentificaron como "Mayero" (es decir, que habla la lengua maya). Las categorías de autoadscripción más recurrentes entre dichos rangos de edad fueron las de "Mexicano" y "Yucateco" (Lizama 2012:141).

En términos de escolaridad, la mayoría de los jóvenes encuestados (los rangos que van de 15 a 24 y de 25 a 34 años) en la Enmimérida sólo cuenta con la secundaria completa. Sólo 3 jóvenes de 15 a 24 años tienen la licenciatura completa y 19 de 25 a 34 poseen dicha escolaridad (Lizama 2012:105-106). Asimismo, encontramos a más jóvenes de 15 a 24 años trabajando (142) que estudiando (99), situación que se acentúa notablemente en el rango de edad de 25 a 34 (160 trabajando, sólo 1 estudiando) (Lizama 2012:110).

En cuanto actividades laborales e ingresos, los encuestados de 15 a 24 años se dedican principalmente a servicios generales (74, el $12.07 \%$ de la muestra), luego a la construcción $(18,2.94 \%)$ y al comercio al menudeo $(18,2.94 \%)$; los de 25 a 34 años se dedican principalmente, también, a los servicios generales (62, 10.11\%), luego a los servicios técnicos $(23,3.75 \%)$ y al comercio al menudeo $(18,2.94 \%)$ (Lizama 2012:132). Por otra parte, la categoría laboral que más se encuentra entre los encuestados entre 15 y 24 años es la de empleado y obrero $(107,17.46 \%)$ y luego trabajador por cuenta propia (26, 4.24\%); sucede algo semejante con los encuestados de entre 25 y 34 años: 110 (17.94\%) empleados u obreros y 37 (6.04\%) trabajadores por cuenta propia (Lizama 2012:136). Por último, en cuanto a los ingresos, la mayoría (192) de los encuestados entre 15 y 24 años no reportó ingresos; 61 reportaron entre 1 y 2 salarios mínimos mensuales (SMM); 35 entre 1/2 y 1 SMM; 31 entre 2 y 3 SMM; 4 entre 3 y 4 SMM; 2 hasta 1/2 SMM y ninguno reportó más de 4 SMM. En cambio, 69 encuestados de entre 25 y 34 años no reportó ingresos; 66 reportaron entre 1 y 2 SMM; 43 entre 2 y 3 SMM; 31 entre 1/2 y 1 SMM; 7 entre 3 y 4 SMM; 5 entre 4 y 5 SMM; 4 hasta 1/2 SMM; 1 entre 5 y 6 SMM y 1 más de 6 SMM (Lizama 2010:139). 
A partir de los datos anteriores, tenemos un perfil de los jóvenes mayas como los que menos hablan, escriben y leen la lengua maya; si bien son los más escolarizados de sus familias, tampoco suelen llegar a niveles superiores de educación; asimismo, cuentan con trabajos ubicados principalmente en el sector servicios y con bajos ingresos.

Los jóvenes mayas a quienes me referiré en este trabajo contrastan con los arriba descritos. Si bien en su mayoría son jóvenes con un pasado pobre y rural, han logrado ubicarse en posiciones socioeconómicas de clase media urbana $\mathrm{y}$, a diferencia de los jóvenes encuestados por el CIESAS, se identifican enfáticamente como mayas. ${ }^{170}$ Asimismo, como muchos de los profesionistas mayas de clase media, estos jóvenes han atravesado procesos de cambio sociocultural que se pueden apreciar en el paso del hábitat vernáculo al urbano, en la cultura material (en las pautas de vestido, alimentación, de ocio y recreo), así como en prácticas rituales (ver López Santillán 2011:104 y ss).

A pesar de la movilidad social ascendente (o, probablemente, también debido a ella), los jóvenes mayas de Mérida han sido víctimas de la violencia simbólica racista, pues, en dicha ciudad, conocida como la "Ciudad Blanca" (Iturriaga 2011), los mayas "siguen siendo considerados inferiores por amplios sectores de la sociedad" (López Santillán 2011:145). Al respecto, López Santillán ha estudiado cómo los profesionistas mayas de clase media han hecho frente a la violencia simbólica racista a través de una serie de estrategias. La más notable es la "capitalización del patrimonio lingüístico”, es decir, cuando "la herencia cultural, el hecho de ser indígena y ser maya hablante" se puede aprovechar en términos de prestigio ("como poseedores de un capital simbólico que cobra fuerza a escala social") y monetario ("para acrecentar el capital económico o lograr la movilidad social ascendente”) (López Santillán 2011:174). En otras palabras, transforman su etnicidad de un estigma a una fuente de beneficios. Y aquí nos encontramos con una paradoja. Como veremos más adelante, la lengua maya se encuentra "entre el estigma y la revalorización"; mientras que desde las instituciones oficiales y la experiencia de los maya hablantes se revalora la lengua maya, "ésta sigue transitando por

${ }^{170}$ Como ha advertido el sociólogo Ricardo López Santillán (2011) en su investigación sobre etnicidad y clase media en Mérida, resulta difícil obtener datos sobre población indígena en posiciones socioeconómicas más aventajadas. No obstante, algunos datos son ilustradores: en Yucatán, tan solo el $6.4 \%$ de los hablantes de una lengua indígena se encuentra en posiciones laborales de clase media. Asimismo, en toda la entidad, poco más de 19 mil hablantes de lengua indígena cuentan con educación superior. Por último, para el caso específico de la Zona Metropolitana de Mérida, los hablantes de lengua indígena con estudios superiores son tan solo el 1.1\% (López Santillán 2011:56). 
lo que parece un irreversible camino al desuso" (López Santillán 2011:166). También hay que notar que, en Yucatán, el gobierno del estado no sólo ha promovido la cultura maya (desde luego, cierta concepción de la cultura, por lo demás alocrónica y folclorista, como vimos en el capítulo anterior), sino que también ha reconocido de manera institucional a parte de la juventud indígena, por ejemplo, por medio de la entrega del Premio Estatal a la Juventud Indígena.

Los actores a quienes me referiré en este trabajo pertenecen, a decir de una de las personas entrevistadas, a una "segunda generación" de mayas que trabajan para la revaloración de su lengua y cultura. Esta generación está conformada por jóvenes, casi todos nacidos en distintas localidades rurales del estado, muchos de ellos hijos de hablantes de lengua maya que cuentan con poca o nula escolaridad, aunque también hay hijos de padres maya hablantes y profesionistas. Asimismo, estos jóvenes emigraron a Mérida para llevar a cabo sus estudios en distintos niveles, o bien, a la ciudad de Valladolid, en el oriente de Yucatán, donde en el 2006 se fundó la Universidad de Oriente. De hecho, todos ellos han realizado o se encuentran realizando estudios superiores o técnicos en los campos de educación, comunicación, informática, contaduría, lingüística y cultura, entre otros. Actualmente, muchos de ellos trabajan como profesores de lengua maya, en instituciones gubernamentales estatales, en medios de comunicación, entre otros ámbitos. Sociológicamente, resulta difícil decir que esta "segunda generación" constituye un "grupo" social, tal como un movimiento social o una organización civil. Más bien, está conformada por una red de actores individuales y colectivos (Latour 2008), que se ha ido tejiendo a partir de compartir estudios, intereses (notablemente la literatura), la participación en políticas culturales y eventos relacionados con la revaloración de la lengua maya.

Podemos encontrar varias continuidades entre la primera y segunda generación de actores mayas que reivindican al pueblo maya. La más notable es que tienen como principal preocupación y demanda la permanencia, desarrollo y revitalización de la lengua maya. ${ }^{171}$ Esta demanda se plantea en un escenario en el que diversos estudiosos

\footnotetext{
${ }^{171}$ También podemos destacar que ambos entablan una continuidad cultural con los "antiguos mayas", a quienes reconocen como ancestros, del mismo modo que parten de cierta "esencialización" de "lo maya", es decir, la creencia de que lo maya es una identidad que han heredado y que poseen dentro de ellos, de tal
} 
han advertido la disminución de hablantes de lengua indígena en la región. ${ }^{172}$ Por ello, varios jóvenes me han planteado que, para ellos, ser jóvenes mayas en la actualidad les representa un gran reto: o son la generación con la que desaparece la lengua o son la que la rescatan y revitalizan. Por ejemplo, una joven estudiante de Contaduría e integrante del colectivo Múul Xímbal — organización conformada por una veintena de estudiantes de la Facultad de Contaduría y Administración de la Universidad Autónoma de Yucatán, y que tiene como objetivo la revaloración de la cultura maya - me comenta:

pues más que nada que los jóvenes ya no están interesados en conocer o aprender la lengua, creo que no sólo en la cultura maya se está dando eso sino en todas las lenguas, que muchos jóvenes ya, los únicos que saben hablar la lengua tradicional son los mayores. Ya no agarran los niños de hoy día un kimbomba, un yoyo o algo por el estilo, y hasta nuestra edad hay jóvenes que ni siquiera lo han tocado y ni siquiera lo conocen, entonces creo que más que nada, ellos, nosotros como jóvenes, ven que nosotros lo hacemos.

A ello, otra joven integrante del colectivo agrega:

Ajá, nosotros queremos ayudar a que siga [la lengua maya] porque está desapareciendo, ya los jóvenes de ahorita ya no quieren hablar en lengua maya, jugar los juegos tradicionales que son antiguos y que no son divertidos, y hablar lengua maya piensan que es como ridículo, eso piensan, por esos motivos se les, se, como que los apaga y ya no los motiva a que sigan con esas tradiciones de lengua maya.

Asimismo, en un artículo periodístico reciente, Yazmín Novelo (2011), una joven maya comunicóloga, ha llamado la atención sobre la "crónica de una muerte anunciada" de la lengua maya, la cual se encuentra "gravemente en peligro", por lo que se debe llevar a

forma que si bien en algún momento de su vida no eran concientes de ella, fueron capaces de "descubrirla" (mas no de "inventarla") (ver Llanes Salazar 2011).

${ }^{172}$ En un trabajo reciente, Pedro Bracamonte y Sosa, Jesús Lizama Quijano y Gabriela Solís Robleda (2011,27) documentan que, mientras que en el año 2000 Yucatán contaba con 549532 hablantes de lengua indígena, la cifra se redujo en términos absolutos en el 2005 a 538355 y advierten que este desplazamiento lingüístico resulta el problema más grave en la región. "Lo más grave, a nuestro parecer, es precisamente ese desplazamiento lingüístico, pues despojados de su mundo antiguo interpretado por sus tradiciones, ahora los mayas pierden la capacidad de rehacer su cultura en una realidad sin mitos, y es que la lengua original ha sido el mecanismo privilegiado de pervivencia de la identidad en las tierras del Mayab" (Bracamonte y Sosa, Lizama Quijano y Solís Robleda 2011, 194). El desplazamiento lingüístico es una de las principales razones por la que titularon a este trabajo Un mundo que desaparece. 
cabo una "revitalización": "darle vida en acción a una lengua que ha ido perdiendo espacios públicos”. El panorama que nos plantea Novelo es desalentador:

las nuevas generaciones no la van aprendiendo [la lengua maya] (y es que, ¿qué ganan con aprenderlo cuando no la pueden utilizar más allá de lo familiar?), está perdiendo espacios públicos sin encontrar nuevos usos (los medios de comunicación tienen algunos escasos 15 minutos en esta lengua porque discretamente, pareciera que no merece mayor tiempo), está relegándose a ser una lengua de uso familiar y cuando una lengua pierde fuerza social, empieza el camino al fin.

Y Novelo formula una pregunta: "En estos tiempos, ¿puede un maya hablante desarrollarse de manera completa en su lengua, sin tener dificultades?" Finalmente, su texto no es tan desesperanzador, plantea la reivindicación de la lengua maya en términos de derechos: "toda persona tiene derecho a vivir en su lengua y su cultura", y se muestra esperanzada de poder revertir la situación, pero para ello, "para que un pueblo pueda lograrlo, primero tiene que tomar conciencia de que es necesario ser pueblo y querer ser pueblo, aún estamos a tiempo, otras experiencias han demostrado que una lengua puede perderse en tres generaciones, o ganar espacios en las mismas" (Novelo 2011). A esta tarea se han dedicado diversos jóvenes, y a continuación describiré sus proyectos y acciones.

\section{La literatura como arena de reivindicaciones étnicas}

La literatura en lengua maya es una muestra de resistencia. Ahora defendemos nuestra identidad con la lengua escrita.

Waldemar Noh Tzec, poeta maya Seminario "Identidad maya y creación intelectual”, Mérida, 1998

Uno de los campos donde los jóvenes mayas están llevando a cabo diversas acciones y proyectos de reivindicación de su pueblo y, particularmente, de la lengua maya, es el de la literatura. Hay que mencionar que la población maya hablante de Yucatán cuenta con una larga tradición literaria que se remonta hasta los tiempos prehispánicos (Barrera Vásquez 1981; Ligorred 1990; 2000) y que, al menos desde la Colonia, la escritura le ha servido a los maya hablantes (especialmente a las elites o intermediarios) para plantear 
diversas demandas al poder (ver Cunill 2012). Sin embargo, es hasta la década de los ochenta del siglo XX que emergió lo que la lingüista y antropóloga Cristina Leirana (2001) ha denominado el "movimiento literario maya contemporáneo", el cual, según ella, puede entenderse como un movimiento "de resistencia":

se encuentra enmarcado en un lento avance de manifestaciones más claras de la pluriculturalidad en el país (de la cual da cuenta la presencia reducida, pero creciente de la lengua maya en los medios de comunicación social). Los autores mayas han llegado por diversas vías a la creación literaria, pero todas están relacionadas con la impugnación o resistencia a las políticas culturales/indigenistas/lingüísticas, instrumentadas al margen de su participación (Leirana 2001:15).

En una línea semejante, el lingüista catalán Francesc Ligorred (2000:334) ha escrito que las creaciones poéticas mayas contemporáneas "ponen de manifiesto la resistencia étnica de los mayas a través de la construcción de un lenguaje poético inspirado en la tradición, pero destinado a constituirse en un elemento esencial para la revitalización cultural maya futura”. Más de diez años después de las aseveraciones de Leirana y Ligorred, el movimiento literario maya contemporáneo ha continuado, se ha desplegado y, en años recientes, diversos jóvenes del estado han comenzado a ocupar un lugar importante en él, como se puede apreciar en la obtención de premios, becas, publicaciones y participaciones en eventos sobre el tema. Pero en este punto cabe preguntar: ¿en qué sentido el movimiento literario maya es uno de resistencia?, ¿sólo resiste a las políticas culturales, indigenistas y lingüísticas, como advierte Leirana?, ¿existen otras arenas y espacios de resistencia? Mi argumento es que, por un lado, desde que el movimiento ha emergido ha logrado controlar y movilizar ciertos recursos culturales, desde el bilingüismo maya-castellano, la lectoescritura en ambas lenguas, puestos de trabajo en instituciones educativas y culturales, publicaciones, prestigio y capital económico a través de becas y premios. Desde luego, con sus obras literarias están reivindicando al pueblo maya y contribuyendo a la gestación de una sociedad más pluricultural. Sin embargo, sus reivindicaciones no se dan de manera ajena a las instituciones oficiales, de hecho, nos encontramos más bien con lo contrario, la mayoría de los recursos que controlan y movilizan provienen de las instituciones oficiales. Por lo tanto, en este sentido, la resistencia resulta en muchas ocasiones ambigua, cuando no tensa. Por otro 
lado, argumento también que con su producción literaria, los jóvenes escritores mayas están contribuyendo a la transformación del orden clasificatorio interétnico hegemónico en Yucatán, gestando nuevas formas de ser jóvenes mayas y de una sociedad intercultural. En este orden de ideas, primero haré referencia al campo social institucional en el que se ubican los jóvenes escritores mayas, para después detenerme en algunas de sus obras literarias. ${ }^{173}$

Las instituciones oficiales del estado (tanto a nivel estatal como federal) han sido fundamentales para el desarrollo de la literatura maya en Yucatán (a diferencia de los estados vecinos de Campeche y Quintana Roo, donde han surgido talleres y grupos literarios autónomos al estado). En 1980 se fundó en Valladolid la Unidad Regional de Culturas Populares de Yucatán (URCPY), dirigida originalmente por el antropólogo yucateco José Tec Poot. En 1982, ${ }^{174}$ la URCPY puso en marcha el Programa de Lengua y Literatura Maya, coordinado por el reconocido escritor Carlos Montemayor, a partir del cual comenzaron a formarse algunos de los más connotados escritores mayas contemporáneos, entre ellos, Feliciano Sánchez Chan (quien en tres ocasiones ha obtenido el Premio Estatal Itzamná de Literatura en Lengua Maya), María Luisa Góngora Pacheco, Miguel May May (quien ha escrito un método para la creación literaria en lengua maya), Santiago Domínguez Aké y Gerardo Can Pat. Asimismo, desde este programa se ha impulsado la colección "Letras mayas contemporáneas" y se han impartido talleres de lectoescritura en diversas comunidades del estado (Leirana 2001:84, 114). ${ }^{175}$

La década de los noventa fue muy activa en términos de la conformación del campo literario maya. En 1990 se llevó a cabo el Primer Encuentro Nacional de

\footnotetext{
${ }^{173}$ Por límites de espacio no haré referencia aquí a otros impulsos institucionales a la literatura escrita en lengua maya, los cuales se dieron, principalmente, durante el gobierno socialista de Felipe Carrillo Puerto (1922-1924) y, años después, con la revista Yikal Maya Than (para más información ver Ligorred 2000).

${ }^{174}$ Vale la pena tener en cuenta que en ese mismo año, 1982, comenzaron a celebrarse anualmente los Encuentros de Cultura Maya y se fundó la radio emisora del INI, Xepet "La voz de los mayas", que transmitía contenidos en lengua maya. Y es a partir de mediados de los ochenta que comienza a impulsarse el desarrollo de un alfabeto para la escritura en lengua maya.

${ }^{175}$ Otros espacios institucionales importantes en el campo literario maya de Yucatán son la Academia de Lengua Maya, A.C., desde la cual Domingo Dzul Poot ha publicado varios libros bilingües con cuentos de la tradición oral, así como el Taller Literario Génali, ubicado en Calkiní, Campeche, al que pertenece la reconocida poetisa maya Briceida Cuevas Cob, así como Waldemar Noh Tzec. Asimismo, diversos escritores reconocidos, como Patricia Martínez Huchim y Vicente Canché Canul, no pertenecen a ninguna organización o institución propiamente literaria (Leirana 2001:130, 142).
} 
Escritores en Lenguas Indígenas, en donde se acordó realizar reuniones estatales y regionales previas a la celebración de los encuentros nacionales. A partir de dicho evento, se han celebrado con frecuencia encuentros de escritores en lengua maya (Leirana 2001:143). Hacia finales de la década, en diciembre de 1998, se realizó en la ciudad de Mérida el I Congreso de Cultura e Identidad, en donde se llevó a cabo la mesa titulada "Literatura y sociedad". Al respecto, cabe considerar la apreciación del filósofo Raúl Alcalá (2009), el movimiento de escritores no es sólo uno propiamente "cultural", sino también uno más explícitamente "político", en tanto los escritores mayas plantean diversas demandas. En el caso de la mesa referida, los escritores demandaron la obligatoriedad de la enseñanza del maya como segunda lengua desde la primaria hasta el bachillerato, así como la creación de una licenciatura en enseñanza de lengua maya (Leirana 2001:147).

Todos estos eventos han sido clave para la conformación de redes de escritores en lengua maya, así como para el aumento de publicaciones en maya y bilingües en maya y castellano. Ha sido también a partir de la década de los noventa que se han creado desde las instituciones oficiales premios dedicados exclusivamente a la literatura maya, como el Premio Estatal Itzamná de Literatura en Lengua Maya, la Medalla al Mérito Literario en Lengua Maya, ambos otorgados por el Gobierno del Estado de Yucatán a través del Instituto de Cultura de Yucatán. Del mismo modo, la Universidad Autónoma de Yucatán ha creado el Premio Alfredo Barrera Vásquez en Literatura en lengua maya en el marco de sus Juegos Literarios Nacionales Universitarios.

En 2008 se creó una de las instituciones que en la actualidad están jugando un papel central en la formación de jóvenes escritores mayas. Se trata del Programa de Formación de Escritores Mayas, en la Escuela de Creación Literaria del Instituto Estatal de Bellas Artes. El Programa tiene una duración de tres años, y en él se contemplan asignaturas sobre lengua maya, literatura maya, poesía, narrativa, dramaturgia, traducción, teoría y crítica literaria tanto en maya como en español, ética del escritor, publicación y difusión de la obra literaria, derechos de autor, entre otros temas. El maestro del Programa es el reconocido poeta maya Feliciano Sánchez (ver capítulo 3 de esta tesis), a quien los jóvenes escritores mayas consideran una gran influencia. En palabras de Isaac Carrillo, escritor maya originario de Peto, en el sur del estado, "la 
escuela fue un abrir de ojos para reconocer cada cosa que tenemos en la lengua y cómo lo podemos usar y cómo podemos conseguir algo estético con las expresiones que usamos".

Para abordar la forma en que los jóvenes escritores mayas controlan recursos y desafían órdenes clasificatorios me basaré en cuatro historias de vida (una joven escritora y tres jóvenes escritores), así como en poemas, cuentos y obras teatrales suyos.

Los cuatro escritores nacieron fuera de la ciudad de Mérida, tres de ellos provienen del sur del estado y el otro es originario del occidente de Yucatán, en la frontera con el estado de Campeche. Todos son maya hablantes desde niños, desde su infancia fueron a la escuela y han realizado o están llevando a cabo sus estudios medios y superiores (en educación, educación artística y lingüística y cultura maya ) en las principales ciudades de la península de Yucatán (Mérida, Valladolid, Campeche).

En los cuatro casos, la incursión en el campo literario maya yucateco fue algo azarosa. En dos casos, sus padres eran escritores en lengua maya e incitaron a sus hijos a escribir en dicha lengua. En los otros dos, sus jefes de trabajo les recomendaron enviar cuentos a participar en concursos. Tres de ellos han ganado concursos, lo que los ha motivado a dedicarse más a la creación literaria. Todos ellos relatan que la lengua maya les ha dejado mucho: han ganado premios (como el Itzamná, el Alfredo Barrera Vásquez de la UADY, el Premio Estatal a la Juventud, un premio de literatura indígena del extinguido Instituto Nacional Indigenista), han obtenido becas del Fondo Nacional para la Cultura y las Artes, han logrado publicaciones en revistas y libros, han viajado a diversos estados de la república para participar en congresos y eventos sobre literatura y lengua maya. Asimismo, todos han o están trabajado en instituciones públicas relacionadas con educación y promoción de la cultura maya.

No obstante, la relación con las instituciones públicas dista de ser completamente armónica. Todos coinciden en que el estado aún no reconoce plenamente la lengua maya y que sus fondos destinados a las artes y a la lengua maya son limitados. Un aspecto que resulta particularmente problemático es el de la traducción. En la mayoría de las ocasiones, para participar en concursos y becas, las creaciones en maya deben estar acompañadas de una traducción en castellano, y en ocasiones, señalan los jóvenes escritores, las obras son evaluadas únicamente en castellano, con lo que no logra apreciarse el aspecto propiamente literario de la obra en maya. Del mismo modo, 
observan la asimetría en el trato de las lenguas: si todo texto en maya debe estar acompañado de traducción al castellano, ¿por qué no sucede lo inverso?, ¿por qué no todo lo publicado en castellano (al menos en el estado) está también traducido en maya? En dos de los relatos de vida se señala con claridad el control y condicionamiento que ejerce el Estado con respecto a sus recursos, por lo que sugieren como una posible vía alternativa el ser promotores culturales independientes (uno de ellos así se identifica), si bien ello implica el control de muchos menos recursos.

Otro problema del que son conscientes estos jóvenes escritores mayas es que, si bien se sienten orgullosos de las trayectorias y reconocimiento que han logrado hasta el momento, también saben que la población maya hablante en general no lee ni escribe en maya, por lo que sus obras difícilmente pueden ser conocidas en las comunidades o incluso en algunas zonas de la ciudad de Mérida. Por esto, uno de ellos señala que uno de sus proyectos actuales es convertir sus cuentos en audio-textos, o bien, realizar más lecturas en espacios públicos, para que su creación llegue a más personas. En este orden de ideas, si bien la obra literaria de estos jóvenes escritores puede enmarcarse en un proceso de resistencia étnica (como señalan Ligorred y Leirana para los escritores mayas en general), también se encuentran con limitaciones institucionales y de las condiciones mismas de lectoescritura maya en el estado.

Ahora cabe preguntarse, ¿cómo se relacionan estos jóvenes escritores mayas y su producción literaria con los órdenes clasificatorios interétnicos hegemónicos? Hay varios aspectos que destacar.

En primer lugar, convencionalmente, se considera que son los ancianos los guardianes de la tradición y de la memoria histórica de los pueblos. De modo semejante, en términos estadísticos, y como también lo anotaron estos jóvenes escritores, por lo general, los jóvenes de origen maya son quienes menos hablan la lengua, quienes menos se identifican como mayas y sienten menos orgullo de su cultura de origen. En este sentido, estos jóvenes escritores no sólo se identifican enfáticamente como mayas y se muestran orgullosos de su cultura, sino que también se sienten guardianes de la tradición y memoria no sólo de sus comunidades de origen, sino del "pueblo maya". Es decir, aquí emerge una categoría poco convencional entre las poblaciones indígenas: los jóvenes guardianes de la tradición y de la memoria histórica. Por ejemplo, en su relato de vida, 
el narrador y poeta Gener Chan señala el sentido "educativo" y normativo de la literatura maya: "te inculca valores, lo que debes y lo que no debes hacer, y [te enseña que] si haces algo malo te va a pasar algo malo". Los cuentos de Gener están basados en las experiencias en su pueblo, particularmente de sus padres y de sus abuelos, y él espera que su literatura eduque a las nuevas generaciones. Además de buscar influencias en otros escritores, "los abuelos son un libro donde hay que aprender muchísimo [... el] porqué decimos esta palabra, su origen o explicación". ${ }^{176}$

En segundo término, si bien todos estos escritores toman como motivos temas de sus comunidades de origen o de la historia del pueblo maya y reconocen la importancia del rescate de las tradiciones, también se consideran creadores. El narrador Vicente Canché lo plantea en estos términos: ha transitado "del que rescata al creador". Pero no se trata de una creación desvinculada de la tradición, sino que se encuentran gestando una forma de creación relacionada con la tradición.

Ciertamente la creación no es algo completamente nuevo en la literatura maya moderna (ver Ligorred 2000), pero estos jóvenes mayas están experimentando con nuevos géneros literarios en lengua maya (como la novela y el monólogo), con formas de combinar la ficción con elementos considerados más tradicionales, así como con formas de focalización narrativa. Un caso ejemplar es el del dramaturgo y narrador Isaac Carrillo, quien ha experimentado con distintas voces narrativas de acuerdo a grupos de edad (particularmente mujeres jóvenes y mujeres adultas mayores). Isaac es consciente de que, en cuanto joven, su vocabulario es más reducido que el de sus maestros y aún más que el de sus abuelos. No obstante, en su obra narra desde la perspectiva de mujer y de adultos mayores. A esto le agrega otra forma de combinar la creación con la tradición o, más bien, con "lo antiguo". "Tengo una fijación por escribir cosas antiguas", me comenta Isaac. Su obra Danzas de la noche, que fue galardonada con el Premio Nezahualcóyotl de Literatura en Lenguas Indígenas, relata el viaje de chan XLool, una niña de trece años, en búsqueda de su padre biológico. Mientras que en su recorrido chan XLool va creciendo de niña a mujer, el viaje parte desde su comunidad de residencia hacia un pueblo antiguo,

\footnotetext{
176 Véanse, por ejemplo, sus poemas "Tumeen in nool/Porque mi abuelo" (“[...] Porque mi abuelo/Me toma de la mano para enseñarme a trabajar/Porque mi abuelo/No se fastidia en ver cómo aprendo;/Porque mi abuelo/entiende cómo me siento cuando me caigo [...]") y "Chéen in chiich/Solo mi abuela" ("[...] Sólo mi abuela,/Saben cómo son mis papás;/Sólo mi abuela/Compone los desaciertos de mis papás;/Sólo mi abuela,/Está cuando mi mamá se va/Sólo mi abuela,/Sabe qué hacer porque también es madre!”).
} 
donde se practican las antiguas danzas mayas. La narración se entremezcla con elementos míticos (como los relatos sobre el origen del día y de la noche, del sol y de la luna) y retoma elementos también de la "sabiduría tradicional" (a manera de parábolas sobre animales y las conductas de las personas). Cabe destacar que, en el prólogo de Danzas de la noche, la crítica Luz María Lepe Lira caracteriza la obra de Isaac como un “pensamiento fronterizo" (en el sentido de Walter Mignolo). En Danzas de la noche, nos dice Lepe, el mundo de los sueños aparece como un "pensamiento otro", refiriéndose a que en el pensamiento maya, los sueños conducen a otro lugar, al inframundo. El viaje de chan XLool es un viaje a través de los sueños, por la Noche, donde "suceden cosas que durante el día cuestan trabajo entender" (Carillo 2011a:21).

Otro ejemplo de recreación de lo antiguo en un contexto contemporáneo es la obra de teatro de Isaac, Paseo de los astros: la muerte del sol. Dramaturgia del cosmos. Los personajes son los astros, los dioses, y la Tierra-Hombre. Los personajes usan taparrabos, plumas, collares de cuentas de maderas, entre otros elementos que aluden al mundo maya antiguo. En la obra se reivindica el saber antiguo (el conocimiento de los astros, cuándo cultivar, etc.), y es también una denuncia al problema ambiental contemporáneo. En palabras de Isaac, "es un llamado de atención a la humanidad”. En una de las escenas, uno de los dioses jaguar expresa: "Ya no hay nada que hacer, tenemos que ofrendarles a los dioses del silencio, a los señores de la oscuridad infinita, ya nadie les recuerda, ya nadie les invoca luz ni calor, ya nadie sigue el camino de su travesía" (Carrillo 2011b:153). Así el Sol va muriendo, la Tierra queda moribunda por culpa del Hombre que ha querido ser como los dioses jaguares.

Otro ejemplo de experimentación es el monólogo escrito por Vicente Canché (2011), "Maya.glob.yuc, peripecias de un indígena en la ciudad". El narrador, Jhon Caballero Estrella, forma parte de la empresa BIENESTAR S.A. DE C.V., y se dirige a personas usuarias de los servicios de dicha empresa. El monólogo es también una crítica a los indígenas migrantes que no solo han ocultado su identidad sino que también desprecian a los pueblos indígenas y la diversidad cultural. Una de las estrategias conocidas de "tránsito étnico" por parte de la población de origen maya es la traducción de sus apellidos mayas al español (ver Quintal 2005:298). Así, es común que Dzul sea traducido a Caballero, mientras que Ek a Estrella. Incluso encontramos casos de 
traducción de nombres españoles al inglés, como Juan a Jhon (con la h delante de la o). En un momento de su monólogo, Jhon es interrumpido por un maya hablante que le llama a su teléfono celular. Jhon hace público su desprecio, cuando se dirige hacia los usuarios diciendo: "estos indios, creen que en cualquier lugar pueden hablar su dialecto", un "dialecto que afortunadamente está en vías de extinción” (2011:121). Asimismo, Jhon aboga por la supresión de la diversidad:

¿Se imaginan cuánto dinero se ahorraría la nación? Ya no habría necesidad de hacer publicaciones bilingües, en vez de sacar una publicación bilingüe se podrían sacar dos libros en español, en vez de gastar impuestos en escuelas indígenas, sería una sola educación para nuestro país. ¿Saben cuánto dinero se pierde por mantener una radio en lengua indígena que nadie escucha? Se gasta miles, quizá millones de pesos. Estoy de acuerdo que se cierren esas radiodifusoras que nadie escucha, dicen los defensores que diversidad, qué diversidad ni que ocho cuartos, México es uno y necesitamos un país fuerte, unido, porque la unión hace la fuerza" (Canché 2011:121).

En tercera instancia, y retomando las consideraciones teóricas esbozadas al inicio de este capítulo, podemos apreciar cómo los jóvenes escritores mayas, en su carácter de agentes, están gestando nuevos emblemas simbólicos en el proceso de reivindicación del pueblo maya. Tal es el caso de la narración de Gener Chan titulada "Maaya K'aak" ("Fuego maya"). El "Fuego maya" es una metáfora de la lengua maya, "fue un regalo de los Dioses" (Chan 2006:112), que, a la llegada de un grupo de hombres blancos, "solamente resolvían las cosas con violencia" (2006:113), ha tratado de ser apagado en varias ocasiones. Sin embargo, los cuidadores del fuego se lo tragaron, lo que "hizo posible que haya una comunicación con los Dioses" (2006:115). Al final del texto, el narrador revela: "El fuego es la Lengua Maya, porque para mí el hecho de tratar de apagar un fuego fue la manera como se quiso desaparecer la lengua maya. Para que un fuego no se apague se tienen que hacer varias cosas, de esa manera se tuvo que cuidar la lengua maya haciendo varias cosas, como hablarlo sin que los hombres blancos se dieran cuenta" (2006:121). En una charla, Gener me explicaba que la resistencia que han hecho los mayas no es una resistencia "aferrada", sino que, como el fuego que ha sido tragado y ocultado a los blancos, ha sido una resistencia adaptativa, en lo privado.

Sobre la relación entre lo tradicional y contemporáneo en la obra de estos escritores, 
así como sobre la forma de resistencia de los mayas, reproduzco un fragmento de entrevista con Gener:

Rodrigo Llanes: algo que igual me ha llamado mucho la atención en todo lo que has comentado es como que, muchas veces se, hasta en incluso en estudios académicos, está esta concepción de que quienes están buscando revalorar la cultura, apuntan únicamente hacia lo tradicional. Algo que me parece muy interesante, un tema, es como sí hay una mezcla, una combinación, entre retomar estos elementos tradicionales, que pueden servir mucho, que sirven mucho, como los valores, la transmisión de conocimientos de los abuelos, con cosas más contemporáneas, como cómo adaptar la lengua maya a nuevas tecnologías, o para la enseñanza. Eh, claro, que no son cosas excluyentes como muchas personas lo ven

Gener Chan: mira, a veces cuando participamos en congresos, en discusiones y todo eso, a mí algo que me ha quedado muy claro y cada vez que lo analizo me confirmo es que, si existimos o la lengua existe después de muchos años, cientos de años de colonia, no fue porque, estem, no fue porque ehm, cómo te digo, porque hubo sistemas o formas de rescate de la lengua, nunca hubo eso, de hecho siempre hubo presión ¿no?, entonces, si hubiéramos peleado más directamente con lo que nos traían los occidentales creo que se hubiera perdido antes, creo que sí, el el el haberse aferrado tanto, esto y enfrentarse hasta morir. Recuerdo una persona que estaba dando una conferencia, no me acuerdo quién, que luego se hizo una reflexión de que, si los españoles luego conquistaron a los mayas o fue al revés, de que totalmente no está hecho, nunca pasó, porque a pesar de que en público no hables en maya, llegando a la casa lo podías hacer, le podías hablar al niño, entonces fueron cientos de años para que la lengua se mantuviera, para que la lengua se transmitiera de manera oral que no hubiera sido posible tal vez si nos hubiéramos aferrado sólo esto es mío, creo que la forma en que se adaptó la persona maya, la cultura maya, a lo que venía, le dio esta lo que nosotros podemos decir ahora nuestra realidad maya, tal vez si se hubieran aferrado, no hubiera existido nada de esto, hubiera quedado en los libros, que había unas personas que hablaban una lengua que se llamaba maya y ahora sólo hablamos español. Yo creo que había ese pensamiento, esta flexibilidad, esta adaptabilidad de las personas, de no aferrarse tanto, sino lo podemos aprovechar sobre todo para seguir hablando, para hacer esto, para hacer lo demás, y este yo creo que las cosas son así, no podemos luchar contra el mundo, no podemos luchar contra el mundo, tal vez debemos aprovechar lo que el mundo nos da para seguir manteniendo nuestra 
cultura, llámese tecnología, llámese oportunidades, llámese preparación, no podemos aferrarnos a que, a que esto tiene que ser así o si no no se hace, creo que eso podría llevarnos a la decadencia, el aferrarse tanto, tampoco hay que como que aprovechar o mezclar tanto que luego vayamos perdiendo la esencia. Sobre todo en mis obras trato de, como tú dices, de poner un poco contemporáneo pero rescatando, es mi visión, lo que yo conozco con lo que yo crecí, yo vivo en un mundo moderno pero yo crecí, yo vi, yo observé muchas cosas, que es lo que yo sigo manteniendo y a lo mejor de esa forma expreso mi pensamiento, yo pienso que de esa forma yo puedo compartir mi visión y proponer eso. Claro, habrá personas que son cien por ciento tradicionalistas y te dirán con lo español no quiero nada, no, yo creo que tenemos que ser más inteligentes y aprovechar todos los recursos que nos dan, todos los avances tecnológicos que nos dan, eh y lograr que nuestro idioma nunca se debilite y que cada vez tenga más fuerza. Por ejemplo, otro dato curioso que a mi siempre me llama la atención es que una cantidad de maya hablantes que por necesidades económicas, tengo y tuve unos parientes por allá, sé que cuando se topan entre ellos hablan maya, ajenos de Yucatán, están aje, están fuera de Yucatán, están fuera de sus tierras, de donde ellos se desenvolvían, están en otro lugar, en otro país, con otras costumbres, con otro idioma, con otras costumbres, con otra forma de pensar, funcionando, que la lengua viva, entonces esa es una de las cosas que digo, no podemos estar aferrado, ya llegué a Estados Unidos sólo voy a hablar inglés, acá no estamos en Yucatán, no estamos en Xaya, en Oxcutzcab, acá vamos a hablar inglés y listo, creo que ellos adaptan su ambiente, su demanda que les hace la vida, para poder aprovechar eso, yo sé que muchos brincan al inglés, por trabajo, y eso es algo que compartimos acá, afortunadamente, una chica se acaba de incorporar, antes el departamento se ha distinguido de que habla totalmente maya en cualquier lugar, donde sea que estemos ya sea en Messenger o en Facebook estamos publicando en maya, tratamos de ser ejemplos para personas que se avergüencen de hablar maya, donde sea que estemos hay que hablar maya, entre ellos es algo común, yo salgo allá y vamos a hablar maya, salimos de Indemaya y en maya, maya, maya. Cuando nosotros no hacemos, cuando no nos comunicamos en maya, sentimos que estamos en un idioma ajeno a nosotros, no nos sentimos bien, es algo que compartimos siempre, nuestra lengua es la lengua maya, yo digo que ese es el sentimiento que tienen las personas, están lejos de Yucatán, cuando te topas con un paisano y puedes hablar en maya te da esa tranquilidad, esa estabilidad emocional de poder expresarte de una forma que siempre has hecho, entonces estém, es un poco lo que yo digo, yo siento que no podemos pelearnos 
con la tecnología, no podemos seguir diciendo vamos a usar lápiz y pluma y así vamos a aprender maya, no, osea hay cosas tan nuevas, tan buenas, que podrían facilitar la enseñanza, claro, hay que aplicarlo bien si no se nos va a ir de un lado o no vamos a lograr nuestros objetivos. Creo que, mi forma de pensar, tenemos que ser más inteligentes, no pelearnos con el mundo, sino aprovechar y cuidarnos siempre de que no nos coman, porque si no nos cuidamos nos puede absorber el mundo, nada más es el cuidado que hay que tener, aprender a vivir con el mundo manda el bombardeo constante del inglés del español, aprendiendo a sobrevivir español maya, aprender a vivir así, no creo que nos traiga problema, el problema es cuando sólo español, o sólo cosas del inglés, estamos dejando nuestro origen, nuestra forma, donde nosotros nacemos, creo que podemos vivir en este mundo, es lo que queremos hacer, y uno de mis proyectos es ese, preparar materiales tecnológicos para la enseñanza de la cultura maya, yo hacerlos y aplicarlos en la enseñanza de lengua maya.

Por último, podemos considerar cómo aparecen los jóvenes en las obras literarias de estos escritores. Actualmente, Gener se encuentra trabajando en una novela que, justamente, tiene como tema el temor y la vergüenza que los jóvenes mayas sienten en la vida en la ciudad de Mérida. Para ello, emplea la figura de un hombre escondido en una cueva que tiene miedo de salir. Sin embargo, los aluxes (unos pequeños duendecillos mayas) incitan a la persona a salir. Los aluxes son como la conciencia, me cuenta Gener, y él espera que su obra literaria también ayude a los miles de jóvenes que sienten temor y vergüenza de ser mayas. En cierta medida, todas las obras y proyectos literarios de estos jóvenes escritores comparten ese propósito y contribuyen a él al desafiar los órdenes clasificatorios interétnicos, donde maya, indio o indígena ya no significa exclusivamente pobre, atrasado, iletrado, sino también alguien de clase media, que vive lo contemporáneo, que es escritor; donde ser joven maya ya no significa solamente ser una persona que siente vergüenza por su cultura y por la lengua maya, sino que siente orgullo de ellas y se manifiesta como guardián de su tradición. Asimismo, gestan nuevas formas de ser mayas, con nuevos emblemas simbólicos y proyectos políticos de reivindicación del pueblo maya. 


\section{Reivindicaciones del pueblo maya y tecnologías en un campo de disputas}

El otro campo en el que podemos encontrar proyectos y acciones de jóvenes mayas para la reivindicación del pueblo maya es el de las nuevas tecnologías de información y comunicación. Al respecto, los jóvenes entrevistados consideran este campo no como algo "avasallador de las tradiciones", sino como un espacio de múltiples posibilidades para la revitalización de la lengua maya. Sin embargo, las prácticas y discursos asociados con las tecnologías en las reivindicaciones de la cultura maya constituyen un campo de tensiones y de disputas entre el control y la distribución de recursos (la tecnología incluida), así como de conflicto entre las categorías simbólicas y órdenes clasificatorios hegemónicos. Del mismo modo, las prácticas y discursos sobre las tecnologías en las reivindicaciones de la cultura maya no constituyen un proceso lineal y teleológico: ni contribuyen únicamente a eliminar la cultura local y tradicional, ni son solamente dispositivos de lucha y de resistencia. Lo fundamental, me parece, es analizar en qué sentido las tecnologías representan posibilidades de realizar las esperanzas y utopías presentes en las reivindicaciones del pueblo maya. A continuación analizo cuatro aspectos de este campo de disputas: 1) la oposición entre la tecnología/moderna y lo indígena/tradicional; 2) una forma de subjetividad que podemos caracterizar como "vivir lo contemporáneo"; 3) el papel que juega la tecnología como actores no humanos en la red de actores mayas y sus dinámicas de sociabilidad; y 4) la tecnología como una demanda explícitamente política.

\subsection{La oposición entre tecnología/modernidad e indígena/tradicional}

En primer lugar, podemos observar cómo la oposición ilustrada entre modernidad/tecnología y tradición/indígena funciona como un "marco" a partir del cual algunos de estos jóvenes relatan sus vidas. Así, cuando narran sus biografías, muchos de ellos señalan con añoranza que nacieron en comunidades rurales "sin tecnología", "sin computadoras", "sin [teléfonos] celulares", y que todo esto ha cambiado notablemente en los últimos años debido a los procesos de modernización. Estos comportamientos enmarcados, como ha observado Rodrigo Díaz Cruz (2008:43), constituyen y crean "eventos sociales contextualizados que exaltan e intensifican la experiencia social". ¿Cuáles son estas experiencias? 
En diversas entrevistas y charlas informales, los jóvenes mayas expresaron la preocupación de que la tecnología moderna está imponiéndose y transformando de manera negativa las relaciones sociales y las prácticas culturales de los mayas. Por ejemplo, denuncian cómo la televisión no sólo transmite contenidos ajenos a las poblaciones locales sino que, sobre todo, desintegra espacios de convivencia entre los ancianos y los niños, destruye sociabilidad. Del mismo modo, algunos jóvenes promotores culturales han señalado cómo las computadoras y los videojuegos, entre otros dispositivos tecnológicos, están desplazando a los juegos tradicionales y otras prácticas culturales de los mayas. La añoranza de los relatos sobre la infancia rural, sin tecnología, se transforma en una nostalgia política, crítica de la modernidad con tecnología.

Asimismo, diversos jóvenes han criticado el hecho de que medios como la radio y la televisión, pero también tecnologías como los teléfonos celulares, las computadoras, distintos tipos de software, entre otros, no sólo siguen reproduciendo la homo-hegemonía del Estado-nación (Derrida 1997; para el caso de Yucatán, ver Ayora Díaz 2012) a través de contenidos de la cultura "occidental" y hablados en castellano, sino que también son vehículos de la hegemonía global, particularmente del inglés, tal como se puede apreciar en muchos de los diseños de computadoras, sitios de Internet, teléfonos celulares, entre otros dispositivos. Después de todo, una de las preocupaciones fundamentales de estos jóvenes es la lengua maya, y estos dispositivos tecnológicos son agentes que forman parte de un inminente conflicto lingüístico. No obstante, no he encontrado, ni en el discurso ni en la práctica etnopolítica de estos actores, un rechazo total a la tecnología moderna y occidental. De hecho, cada vez más encontramos la tendencia contraria, y esto se da en varios sentidos que a continuación abordaré.

\subsection{Vivir lo contemporáneo}

En su ensayo Ciencia y técnica como “ideología”, Jürgen Habermas (1986) argumentó que la ciencia y la tecnología tuvieron un impacto primero en la vida cultural y en el mundo de la vida, y después en la economía y en la administración. Retomando esta idea, podemos argumentar que las nuevas tecnologías de información y comunicación constituyen dispositivos a partir de los cuales los jóvenes mayas median su relación con el mundo o, en otras palabras, viven lo que Paul Rabinow (2007:24) ha denominado el 
ethos de lo contemporáneo, el cual, en oposición a lo moderno, no es una mera fascinación por lo nuevo, sino que está interesado en la emergencia y articulación de formas en las cuales viejos y nuevos elementos se cargan de significados y funciones. ¿Cómo viven estos jóvenes mayas lo contemporáneo?

Podemos señalar, en primera instancia, que a través del uso de las nuevas tecnologías y dispositivos como teléfonos celulares, servicios de mensajería instantánea (ver May May 2010), blogs, páginas web, cuentas de Facebook y Twitter, podcasts, entre otros, los jóvenes mayas redefinen las nociones de indigeneidad en general y de lo maya en particular. Es decir, lo maya deja de ser identificado únicamente con lo tradicional, lo campesino, lo pobre, lo atrasado, lo desconectado, algo que está atrapado en los territorios de un anacrónico pasado, y comienza a asociarse también con lo global, lo conectado y las nuevas formas de subjetividad que emergen con las nuevas tecnologías. Tomemos como ejemplo el sitio electrónico El Chilam Balam. Noticias desde el Corazón de Yucatán [<elchilambalam.com>], que retoma su nombre de los famosos textos religiosos, médicos, cronológicos, astronómicos, rituales, literarios y proféticos que han sido claves para la interpretación de la historia de las sociedades mayas. A decir de uno de los creadores del sitio, un joven maya que estudió sistemas informáticos, el sitio surgió cuando un amigo y él cayeron en la cuenta de que se escribían constantemente en maya en medios como Facebook y Twitter. Pero, sobre todo, porque consideraban que no existía un medio que contara noticias relevantes que suceden entre la población maya del estado. La página está casi en su totalidad en castellano, pero incluye una sección titulada "Aprende Maya", y una parte considerable del material y las noticias que difunde están relacionadas con la lengua y su enseñanza. El sitio también tiene una página en Facebook y una cuenta en Twitter, y frecuentemente (unas cuatro o cinco veces al día), sus programadores suben mensajes en maya con traducción en español, empleando los hashtags "\#mayas" o "\#MundoMaya". Uno de los aspectos interesantes de estos sitios es que contienen hipervínculos y están interconectados con otros espacios, donde uno puede leer comentarios sobre la presunta profecía apocalíptica de los mayas (“\#FinDelMundo”), que el iPhone5 "fue pensado por los \#mayas", que los mayas anunciaron el fin del euro, o peticiones de que se acabe el mundo antes de que Enrique Peña Nieto tome posesión 
como presidente de México. ${ }^{177}$ Asimismo, en la sección de "Aprende Maya" se incluyen traducciones de frases comunes de estos espacios, como del "meme" forever alone: tin juun tak mix bin'in. No cuento con los elementos suficientes para argumentar que estas expresiones constituyen ejemplos de lo que Pedro Bracamonte y Sosa ha denominado "pensamiento maya", un pensamiento basado en el tiempo cíclico y en los vaticinios, y que ha caracterizado como una "forma peculiar de pensamiento", "un modo diferente de experimentar la realidad" (Bracamonte y Sosa 2010:8-9). Lo que sí quiero destacar es que estas tecnologías no sólo sirven para reproducir la tradición o el pasado, sino, principalmente, para vivir lo contemporáneo, emplear elementos considerados "tradicionales" de los mayas para interpretar (ya sea seriamente o en tono de broma [Armstrong-Fumero 2009; Loewe 2011]) eventos actuales.

Otro elemento importante de este ethos de lo contemporáneo es lo que Mark Goodale (2006) ha llamado "cosmopolitismo indígena", es decir, la habilidad de los líderes indígenas, pero también de jóvenes raperos y de otros activistas andinos, de conjugar marcos discursivos aparentemente dispares para reimaginar categorías de pertenencia nacional así como los significados de la modernidad misma. Tal como en el caso de Bolivia descrito por Goodale, en la península de Yucatán también encontramos a jóvenes que han conformado bandas de rock-reggae, como Saatal Paax, con letras en maya y castellano que versan sobre los guardianes mayas, las tierras y la naturaleza, entre otros aspectos importantes de la cosmovisión maya. En su página en Facebook, los integrantes de Saatal Paax exponen: "somos un grupo de personas que amamos la cultura maya, interesados en eventos y practicas [sic] ancestrales que nos han heredado y es nuestro legado... y es nuestra mision [sic] llevar nuestros conocimientos al infinito; donde nuestras voces sean escuchadas. Nuestra voz por medio de la música y la lengua maya". ${ }^{178}$ En este punto, pareciera que el interés reside únicamente en "eventos y prácticas ancestrales" heredadas, pero como me platicaba uno de los guitarristas y compositores de la banda, también tienen interés por estilos musicales actuales así como por problemas contemporáneos (particularmente el ambiental), por lo que su música no debe entenderse únicamente como un mero rescate del pasado o una fascinación por lo

\footnotetext{
${ }^{177}$ Todos estos eventos tuvieron lugar en el año 2012.

${ }^{178}$ Tomado de: <http://www.facebook.com/saatal.paax $>$.
} 
nuevo, sino como una preocupación sobre cómo se articulan ambas cosas. Del mismo modo, en la península encontramos a Pat Boy, rapero maya que, si bien se encuentra en el estado vecino de Quintana Roo, es una referencia para varios jóvenes de Yucatán y los comentarios a sus videos en YouTube son realizados por personas de distintos lugares, incluyendo Yucatán. ${ }^{179}$ Uno de los argumentos que quiero desarrollar es que estos ciberespacios no sólo son legítimos espacios etnográficos (como ya han argumentado Boellstorf 2008; Postill 2008, entre otros), sino que también constituyen lo que Anna Tsing (2005) denominó zonas de "fricción", que metodológicamente resultan clave para entender procesos de negociación y disputa de significados de categorías de clase, etnia, género, de identidad, de nacionalidad, de estética, entre otras. Por ejemplo, en los comentarios realizados a uno de los videos de Pat Boy, podemos apreciar cómo el orgullo se expresa con la categoría "pirámide” (“Los Mexicanos hacemos pirámides!!!"), así como discusiones sobre si la aceptación de la música es por la música misma o porque es rapeada en maya. Entran en juego concepciones sobre "raza" y "etnia" (como "que [sic] bueno que rescates tu cultura... que malo que cantes RAP... que es musica [sic] de negros"); sobre identidades "mexicano", "maya guatemalteco", "maya de Quintana Roo"; de clase ("ponte a estudiar q te moriras [sic] de hambre"); así como elementos que refieren directamente a las redes sociales mismas (como la alusión a la celebridad de Youtube, la quinceañera "Colibritany"). Así que, si bien estos jóvenes mayas redefinen lo que significa ser mayas, encontramos otras concepciones que siguen estereotipando de manera negativa a lo indígena. Al respecto, Eugenia Iturriaga y Valiana Aguilar (2014) han documentado algunas expresiones de discursos racistas hacia lo indio en Twitter.

Así, para muchos jóvenes mayas, la cultura maya ya no remite únicamente a lo tradicional. A continuación reproduzco un fragmento de la grabación de un grupo focal con los integrantes de Múul Xímbal:

Alfonso Rodríguez (AR): Sí, como dicen, ser de la cultura maya no significa traje típico, y de comer todos los días comida regional

Risas

179 Como vimos en el capítulo anterior, Pat Boy participó en la inauguración del Festival Maya Independiente Cha'anil Kaaj, celebrada el 12 de octubre de 2013 en Oxkutzcab, en el sur del estado de Yucatán. 
AR:

y hablar solamente en maya, vivimos las fiestas, los..., los..., las tradiciones, las vivimos junto con ellos, inclusive en el dialecto tal vez no somos maya hablantes pero sabemos palabras y muchas de las expresiones que usamos provienen de esa lengua, por eso es muy importante.

Rodrigo Llanes (RL): y por todo lo que dicen ustedes se identifican como mayas

\section{Todos: Sí}

RL: y desde cuándo surgió esto, porque dices, con mucha razón, para muchos es es algo ridículo, vergüenza, motivo de vergüenza, se valora más lo extranjero, cómo surge en ustedes esta identificación con la cultura maya o este sentimiento de pertenencia con la cultura maya

Risas

Fabiola: Por mi parte me llama la atención porque, em.., la familia de mi mamá que si viene de México, viene de otros lugares, no tiene la cultura de aquí. Pero mi mamá ya al vivir acá tiene algunas costumbres. Por parte de mi papá sí son de acá, mis abuelas son mestizas, igual, y aunque he crecido acá en la ciudad, hay costumbres que ya se perdieron, costumbres que ya no al menos ellos, entonces siempre me ha llamado la atención lo que se hace, sobre todo en los pueblos, no todo, pero sí hay cosas muy diferentes a las que se hacen aquí en la ciudad, todo eso desde siempre me ha llamado la atención, y aparte de la lengua maya siempre he querido hablar maya, desafortunadamente nuestros papás no hablan maya aunque nuestras abuelas eran maya hablantes, mi papá no lo aprendió al cien por ciento y por lo tanto no lo habla, pero sí, fue este, entiendo maya desde siempre

Risas

Cristóbal: desde mi punto de vista yo no tuve el privilegio de que mi familia fuera completamente maya hablante, sólo mis abuelos por parte de mi madre eran maya hablantes, entonces sí tenía como ese choque de encuentro o pertenencia de que no sabía, 
soy proveniente de la ciudad, no conocía las costumbres, me identifico con la cultura maya en el sentido de que parte aprendí, viví, lo que ellos querían representar. Como repetí anteriormente, esa visión que ellos tenían de las cosas de que no sólo lo hacían por el simple hecho de hacerlo, sino de que todo tenía un por qué, todo estaba ligado, aprendí a comprender eso, me di cuenta de que yo era parte de ello porque si ellos no hubiesen hecho todo lo que han hecho nosotros no estaríamos aquí, esa es una de las cosas que yo me identifico, que soy parte de eso.

RL: y otra palabra que está ligado a lo que dices, los mayas, o los antiguos mayas, que igual es una palabra que se escucha mucho, qué piensan

C: que es despectivo... que es despectivo porque es como que es algo que ya ha pasado, como repetía, que era una moda, una tendencia, de que desgraciadamente a los mayas los toman en cuenta como muy bajo culturas actuales, como las potencias europeas en el antiguo continente em, a los mayas los utilizan a veces como parte para hacer promociones, por ejemplo, relacionado con el 2012 utilizan erróneamente lo que es la cultura para atraer, para vender, ya no la estudian por el amor, por el arte que es, la utilizan para vender, es algo despectivo

AR: Con relación a eso también pienso que es lógico que las culturas tiendan a evolucionar; muchas, muchos ritos o tradiciones que se tenían, sacrificios y cosas por el estilo que ya no son permitidas porque hay un nivel diferente, y pienso que eso de mayas antiguos y mayas actuales pues no es como que una diferencia muy grande sino que es una transición que lógicamente todas las culturas tienen que vivir y adaptarse, método de adaptación, aceptar otras creencias y respetarlas.

\subsection{Actores no humanos y formas de sociabilidad}

Mencioné antes que los jóvenes mayas de los que aquí he tratado conforman una red de actores. Quiero destacar ahora otro elemento de esta red, lo que Bruno Latour (2008) ha caracterizado como "actores no humanos". Con el concepto de actores no humanos, Latour hace referencia a la "capacidad de agencia" de los objetos; esto no quiere decir que los objetos tengan conciencia o voluntad, sino que son elementos activos y 
fundamentales de las asociaciones y dinámicas de sociabilidad de los humanos; los actores no humanos son "participantes en el curso de acción a la espera de que se les dé figuración” (Latour 2008:107). Así, las nuevas tecnologías de información y comunicación son elementos constitutivos de las redes de actores mayas, son actores no humanos fundamentales en los procesos de organización y de sociabilidad de dichas redes. Desde luego, como ha argumentado Latour, los actores no humanos siempre han sido constitutivos de las redes de actores que involucran a los humanos (como bien se puede apreciar en la escena inicial de 2001: una odisea al espacio, de Stanley Kubrick). Así, brazaletes y collares de conchas, ganados y lanzas, máscaras y gallos, todos ellos son constitutivos de las formas de sociabilidad y han estado presentes en las etnografías clásicas. Podemos agregar que en los escenarios contemporáneos marcados por intensos procesos de desterritorialización, de "dislocación y diferencia" del "nuevo orden global" (Appadurai 2001), las redes sociales digitales constituyen fuertes contrapesos de reterritorialización (ver Miller 2011 para el caso de Facebook), tanto a nivel local como translocal.

Como han señalado diversos analistas (Juris 2012; Sassen 2011) a propósito de las llamadas "revoluciones" de Facebook o Twitter (como se les ha considerado a la Primavera Árabe, el Occupy Wall Street, los indignados españoles o el \#YoSoy132 en México), las redes sociales digitales no sustituyen la importancia de las relaciones directas de cara a cara, más bien éstas se conjugan de diversas formas. Por lo tanto, hay que reconocer cómo participan estos actores no humanos en los distintos movimientos sociales, como los procesos de reivindicación étnica y de revaloración cultural. Por ejemplo, de acuerdo con los integrantes del colectivo Múul Xímbal, Facebook ha sido clave para la creación de eventos (proposición de fechas, horas y lugares), para la circulación de información, para detalles de la organización (cómo irán vestidos, qué deberá llevar cada quién), así como para la retroalimentación de eventos, la circulación de fotos y comentarios. A pesar de que todos viven en la misma ciudad, Facebook, los teléfonos celulares, las computadoras y otros dispositivos de información y comunicación ya son actores no humanos constitutivos de sus dinámicas sociales y de sus distintas actividades de revaloración de la lengua y cultura maya, todas ellas a nivel "local". Sobre 
este tema, reproduzco otro fragmento del grupo focal realizado con integrantes del colectivo Múul Xímbal:

Cristóbal: como le decía el maestro Gener nosotros no siempre coincidíamos para hablar pero en lo que es las redes sociales como Facebook publicaba alguien una fecha y preguntaban quién puede participar nosotros opinábamos, cuando había un evento, qué había que llevar, cómo teníamos que vestirnos, eso nos ayudaba. En cierta forma igual se había planteado hacer una página web y uno de nosotros, que en el momento ya no está, se llamaba Edwin

Aurora: $\quad$ se llama

Cristóbal: $\quad$ se llama Edwin

Risas

\section{Cristóbal:}

Una página en la cual las

actividades que habíamos hecho las tenía en esa página una invitación para que ellos vean lo que nosotros hacíamos y funcionaba porque algunas personas al maestro Gener le hablaban le preguntaban quiénes éramos nos dieron a conocer, gracias a eso fue que nos invitaron a eventos, que nos conocieron en otras facultades e incluso que hayan querido.

Las redes sociales también juegan un papel clave a nivel translocal, pues facilitan las conexiones con organizaciones, movimientos y otros actores étnicos en distintas partes de México y del mundo, como en Ecuador y Bolivia, gestando así también un sentimiento de cosmopolitismo étnico. Es así que, por ejemplo, circulan ideas y proyectos de Chiapas, Oaxaca y Michoacán, de países andinos (como las teorías y prácticas del "Buen Vivir"), e incluso experiencias de autonomía de Barcelona. Si bien hasta el momento no se ha constituido una red translocal fuerte y visible, ésta comienza a surgir y erigir como una posibilidad concreta de sociabilidad y organización de reivindicaciones de la cultura. 


\subsection{Tecnología como demanda}

Las nuevas tecnologías de información y comunicación no sólo son "medios" de constitución de subjetividades, de vivir lo contemporáneo, de organización y de sociabilidad. Si bien todos los aspectos antes mencionados podrían considerarse "políticos" en tanto que están inmersos en relaciones de poder, podemos señalar como un aspecto más que las nuevas tecnologías constituyen actualmente una demanda central que los jóvenes mayas consideran que es fundamental para la revitalización de la lengua maya. Así, en la Declaración Política del Movimiento Indígena Nacional ante los Desafíos del Siglo XXI, elaborada en noviembre del 2011, y en la que participó una de las jóvenes comunicólogas entrevistadas, se exige como una demanda "asignar a los pueblos indígenas un porcentaje del espectro radioeléctrico". En los discursos y en la práctica, el derecho a las nuevas tecnologías aparece íntimamente relacionado con el derecho a la lengua propia.

El control y acceso a los medios de comunicación también ha sido una de las demandas en la "lucha legal" por parte de diversos actores mayas y no mayas, tal como se puede apreciar en las distintas propuestas de reforma a la constitución estatal e iniciativas de ley en materia de derechos indígenas (ver capítulo 4 de esta tesis). En este sentido, un grupo de jóvenes que ha trabajado en medios de comunicación se está organizando en una asociación civil (aún sin nombre) para aprovechar lo ya establecido por la ley y trabajar en la revitalización lingüística justo a partir del trabajo con medios de comunicación, particularmente con televisión y radio en lengua maya. Una de las jóvenes que está constituyendo la organización es muy conciente de lo problemático que resulta la demanda de la "democratización de los medios de comunicación", y si bien considera que Internet y la televisión son medios clave para sus proyectos de reivindicación, la radio es un ámbito que no se puede abandonar, ya que es el principal medio de comunicación en la mayor parte de las comunidades del estado. Asimismo, las principales impulsoras de esta asociación civil afirman que los contenidos que se transmitan en televisión y radio no deberán tratar únicamente de aspectos considerados “tradicionales" o temas “culturales", sino que se deberán abordar cualquier tipo de tópico. Así, se contribuirá a la superación de la concepción de que lo maya es lo tradicional. 
Retomando al filósofo Andrew Feenberg (2010) podemos observar que con estas demandas los jóvenes mayas dotan de diferentes significados a las nuevas tecnologías de información y comunicación: ya no son sólo medios de información, de comunicación, de consumo y entretenimiento, también se convierten en dispositivos de lucha; ya no sólo son una imposición de la "modernidad" o de la "globalización", sino también de revitalización étnica y particularmente de la lengua maya. 


\section{CONCLUSIONES}

"La realidad no tiene un tamaño determinado. El mundo no se ha acabado todavía", escribió el filósofo alemán Ernst Bloch (1980:258). Retomando esta idea de Bloch, así como la tesis compartida por los antropólogos procesualistas y otros estudiosos constructivistas de que la realidad sociocultural está abierta — "no se ha acabado todavía" - y en permanente proceso de construcción, en estas conclusiones no pretendo "cerrar" o dar por "concluido" un proceso sociocultural particular, el de las reivindicaciones del Pueblo Maya, sino dar respuesta a las preguntas planteadas al inicio de esta investigación, formuladas en la "Introducción" de este trabajo. En otras palabras, busco dar cierre a la etapa de una investigación.

El primer objetivo planteado en esta tesis fue contribuir a la discusión en torno a la relación entre etnicidad y poder. Como vimos en la primera parte de este trabajo "Poder y etnicidad: discusión teórica"-, actualmente, los enfoques hegemónicos en el estudio de la etnicidad y el poder son aquellos que analizan las transformaciones de la "indigeneidad", así como los vinculados a los programas de la teoría poscolonial y la crítica a la colonialidad-modernidad. En todos estos casos, la etnicidad y el poder son conceptualizados primordialmente como formaciones discursivas, como órdenes clasificatorios simbólicos que definen la relación entre lo indígena y lo no indígena: tradición y modernidad, salvajismo y civilización, rural y urbano, local y global, entre otras entidades discursivas-simbólicas.

Uno de los hallazgos importantes de los enfoques arriba mencionados es la constatación de las transformaciones de la "indigeneidad" o de las formas de ser indígena en la actualidad: gracias a las reivindicaciones étnicas y las movilizaciones indígenas ser indígena ya no es sinónimo exclusivo de ser "tradicional", "pobre", "atrasado", "local", etc., sino que existe una diversidad de manifestaciones identitarias indígenas y étnicas 
vinculadas con "lo moderno", las clases medias y altas, lo global, entre otras categorías. Del mismo modo, los enfoques poscoloniales y de la colonialidad-modernidad no sólo han dado cuenta de los cambios de la indigeneidad en América Latina, sino también han destacado rutas de transformación política, especialmente aquellas que se vinculan con la modificación de los sistemas clasificatorios hegemónicos, ya sea a través de elementos "fronterizos" (como en el caso de Mignolo) o de la "exterioridad" del sistema mundo (como ha advertido Dussel).

No desdeño las contribuciones de los enfoques anteriores. Sin embargo, me parece que su énfasis en las dimensiones discursivas o simbólicas presenta limitaciones tanto en términos analíticos como en la comprensión del alcance político de las reivindicaciones étnicas. En este sentido, me parece clave entender el poder a partir de una doble dimensión: junto a la que refiere a los órdenes clasificatorios simbólicos, aquella que alude al control de recursos significativos. El poder no sólo consiste en definir simbólicamente la realidad, sino también en la capacidad de tomar (o delegar) decisiones con base en el control de recursos.

Un aspecto fundamental en el análisis del poder es dilucidar la manera en que ambas dimensiones - el control de recursos y los órdenes clasificatorios- se vinculan entre sí. Finalmente, no son aspectos separados de la realidad, sino que únicamente se pueden distinguir analíticamente. En este orden de ideas, a lo largo de este trabajo hemos visto cómo una serie de actores, que pueden ser caracterizados como intermediarios político-culturales, lograron controlar diversos recursos, como el bilingüismo mayaespañol, educación formal y conocimientos sobre historia y cultura que podrían ser considerados "capital cultural", redes de relaciones, entre otros elementos que, ante determinadas estructuras de oportunidades — como los cambios en la política indigenista y cultural del Estado Mexicano en el último cuarto del siglo $\mathrm{XX}$ - se volvieron recursos significativos que fueron clave en la emergencia de su etnicidad. Es decir, en contra de ciertas ideas comunes, la etnicidad no es una esencia, no es algo que los actores individuales y colectivos portan naturalmente o por el simple hecho de ser culturalmente diferentes. La etnicidad es la politización de la diferencia cultural y de la ascendencia, de la continuidad con unos ancestros, y esa politización no ocurre de la noche a la mañana 
- como si fuera el súbito despertar por el beso de un príncipe-, sino que tiene lugar gracias al control de recursos. Gracias al poder.

El control de recursos significativos le permitió a los actores étnicos, identificados como mayas, apropiarse y también desafiar los órdenes clasificatorios simbólicos hegemónicos. En ocasiones, los mayas protagonistas de esta investigación se identificaron con las entidades discursivas de los órdenes clasificatorios hegemónicos, es decir, se asumieron como "tradicionales", "pobres", "locales" y "rurales", pero, en otros casos, cuestionaron dichos órdenes clasificatorios hegemónicos. Esto fue especialmente notable en el caso del Festival Maya Independiente Cha'anil Kaaj, que criticó severamente la concepción gubernamental, mercantil y turística de la cultura maya como la grandiosa civilización maya antigua, del pasado, muerta, y reivindicaron una visión de la cultura y el pueblo maya como una entidad viva, contemporánea y diversa. También fue el caso de los jóvenes mayas que desafían las oposiciones binarias vinculadas con la tradición y la modernidad: ellos se definen como jóvenes mayas urbanos, que guardan la tradición pero que también viven lo contemporáneo; que a través de diversas formas de creación literaria y de uso de nuevas tecnologías de información y comunicación buscan preservar la lengua maya, actualizarla y revitalizarla.

Las transformaciones en la distribución del control de recursos y de los órdenes clasificatorios hegemónicos sin duda alguna ha traído beneficios a algunos sectores de la población maya: además de una movilidad social ascendente - como en el caso de los protagonistas de esta investigación-, también ha significado un mayor reconocimiento para dichos actores.

Las reivindicaciones del Pueblo Maya en Yucatán han significado, entonces, tanto una modificación en el control de recursos como en los órdenes clasificatorios hegemónicos que definen la relación entre lo maya y lo no maya en el estado. A partir de las premisas teóricas anteriores, me parece que queda pendiente una pregunta fundamental: ¿en qué medida los cambios en los órdenes clasificatorios hegemónicos como las nuevas concepciones de "ser maya" y la reivindicación de un Pueblo Maya vivo y contemporáneo- incidirán en una mayor distribución de los recursos entre la población? 
En segundo lugar, en esta tesis me propuse contribuir al análisis de las reivindicaciones étnicas en México y América Latina en el contexto político de la crisis del "socialismo realmente existente", del "fin de la historia" y "fin de las utopías", en el que los movimientos indígenas y los proyectos de reivindicación étnicas se plantean como nuevas utopías. En este escenario político, las reivindicaciones del Pueblo Maya en Yucatán, así como otros movimientos de reivindicación étnica —notablemente, el movimiento pan-Maya de Guatemala analizado por Warren (1998) - pueden ser caracterizados como movimientos de "luchas por el reconocimiento" (según Charles Taylor, Nancy Fraser y Axel Honneth), "movimientos por la identidad/diferencia" (de acuerdo con Iris Young) o "movimientos por los derechos culturales y la ciudadanía multicultural” (como planteó Will Kymlicka). Las reivindicaciones del Pueblo Maya en Yucatán no son de carácter beligerante, mucho menos se asemejan a las guerrillas latinoamericanas de la segunda mitad del siglo XX; tampoco tienen como demandas centrales problemáticas de "clase" o de "redistribución" socioecónomica; las reivindicaciones del Pueblo Maya en Yucatán son fundamentalmente reivindicaciones culturales, demandas por el reconocimiento de la diferencia y de la identidad. La principal preocupación y demanda ha sido la lengua maya: su reconocimiento, preservación, revitalización y actualización.

¿Qué tipo de política han protagonizado los mayas que reivindican a su Pueblo? Como vimos en los capítulos etnográficos de esta tesis, uno de los ámbitos políticos fundamentales ha sido el jurídico, particularmente el discurso de los derechos humanos de los pueblos indígenas. Ese ha sido el principal referente para reivindicar al Pueblo Maya, tal como se pudo apreciar en el análisis del proceso de legislación en materia de derechos y cultura maya, pero también en el caso del Festival Maya Independiente Cha'anil Kaaj y, en cierta medida, en los diversos proyectos de jóvenes mayas.

Sin embargo, como ha observado la filósofa Seyla Benhabib (2006), las luchas contemporáneas por el reconocimiento no están necesariamente desarticuladas de las demandas de redistribución. "Lo que resulta novedoso — escribe Benhabib (2006:22) es que los grupos que actualmente se constituyen en torno de dichos indicadores identitarios exigen el reconocimiento legal y la distribución de los recursos del Estado y de sus organismos para preservar y proteger sus especificidades culturales”. El verdadero 
o auténtico reconocimiento — como también ha escrito Honneth- exige una justa distribución de los recursos.

Las reivindicaciones del Pueblo Maya no tienen como referente, entonces, al socialismo, al comunismo o a los discursos marxistas de emancipación y liberación —a pesar de que estos están viviendo un resurgimiento tras la crisis financiera de 2008. En cambio, sus referentes utópicos son, fundamentalmente, el Ejército Zapatista de Liberación Nacional — con sus consignas de "Otro mundo es posible", "Un mundo donde quepan muchos mundos" y la noción de "mandar obedeciendo"- así como el "Buen Vivir" de Bolivia y Ecuador.

En este punto, cabe retomar el dilema entre utopía y distopía planteado al inicio de este trabajo. ¿Las reivindicaciones del Pueblo Maya en Yucatán representan una utopía o más bien se asemejan a los escenarios distópicos advertidos por algunos estudiosos? Si bien en un inicio consideré que las reivindicaciones del Pueblo Maya se ajustaban muy bien a lo que Charles Hale caracterizó como un "multiculturalismo neoliberal", que sólo permite a cierto tipo de actores étnicos y una clase de demandas las "culturales", como la lengua y la educación, pero no las "materiales", como tierras y recursos naturales-, debo señalar que en el transcurso de la investigación pude apreciar cómo la oposición entre demandas culturales y demandas materiales —así como la de reconocimiento y redistribución - no siempre se puede sostener con facilidad. La principal demanda de las reivindicaciones del Pueblo Maya, el reconocimiento de la lengua maya, implica una considerable redistribución de recursos para políticas y programas de rescate, conservación, revitalización y actualización de la lengua; para certificar dependencias gubernamentales que puedan atender en lengua maya; para la formación de traductores e intérpretes, entre otros aspectos. Lo mismo se puede argumentar con respecto a otras demandas como la educación intercultural y bilingüe.

Sin embargo, me sigue pareciendo pertinente la observación de Hale referente a que el "multiculturalismo neoliberal" sólo permite a actores étnicos que no son subversivos con respecto al poder. Cabe recordar entonces que los protagonistas de las reivindicaciones del Pueblo Maya no han buscado una confrontación frontal con el estado; si bien son críticos de sus políticas hacia la cultura maya, también colaboran con él en varios aspectos. Podemos preguntarnos, ¿la actitud de no confrontación es una 
actitud conservadora con respecto al poder o, más bien, se trata de una actitud estratégica para alcanzar determinados fines?

En un plano más bien normativo, me parece que la transformación hacia una sociedad más justa y equitativa en términos interculturales sólo se realizará si los actores movilizados logran articular demandas de reconocimiento y de redistribución y si, en palabras de Boaventura de Sousa Santos y Toni Negri y Michael Hardt, logran "intersectarse" o "traducir" sus demandas con la de otros movimientos y organizaciones. ¿Se vincularán las organizaciones mayas y los actores identificados como mayas con las luchas de ejidatarios ante el despojo de sus tierras o de los apicultores en contra de empresas de transgénicos?, ¿lo harán con los movimientos feministas o estudiantiles del estado? Queda pendiente el análisis de la intersección entre las organizaciones y actores mayas con otros movimientos y organizaciones. No es un asunto menor, sobre todo si recordamos, con Guillermo Bonfil y Esteban Krotz, que el llamado "problema indígena" no es el problema de un sector de la población, sino del modelo general de organización de la sociedad.

Con todo lo anterior quiero señalar que si bien las reivindicaciones del Pueblo Maya, hasta el momento, han beneficiado principalmente a un sector determinado y relativamente pequeño de la población maya hablante en Yucatán, esto no significa que dichas reivindicaciones resulten perjudiciales a la mayoría de la población maya hablante. No es necesariamente una distopía, en la que el reconocimiento de unos pocos significa el detrimento de la mayoría. Sin embargo, si lo que nos interesa es la justicia y la equidad intercultural, sí debemos estar pendientes de que las políticas del estado dirigidas hacia el reconocimiento y bienestar de la población maya no se limiten al reconocimiento de una minoría, de un reducido sector que sí se identifica como mayas y que reivindican a su Pueblo.

Y si bien las reivindicaciones del Pueblo Maya no pueden ser consideradas una distopía que sólo pueden beneficiar a una elite étnica, resulta complicado caracterizarlas también como una utopía. Acaso sería más atinado señalar que más que una utopía propiamente formulada (como un programa o proyecto político o ideológico), las reivindicaciones del Pueblo Maya presentan aspectos utópicos, lo que Bloch (1980:262) caracterizó como utopías "concretas" o como "tendencias y posibilidades sociales 
existentes": plantean algunos elementos para la construcción de una sociedad intercultural, en la que la diversidad es reconocida, en donde hablar la lengua maya, portar un apellido maya y provenir de una comunidad rural no son motivos de vergüenza, como lo siguen siendo para muchas personas en la actualidad.

¿Por qué me ha parecido importante el esfuerzo en entender las reivindicaciones del Pueblo Maya como utopía o distopía? Con los protagonistas de esta investigación comparto el deseo y la aspiración de una sociedad más justa, interculturalmente equitativa. Es justo por ello que me parece fundamental apreciar las tendencias utópicas concretas en las reivindicaciones, que apuntan hacia esa sociedad mejor, y advertir también los posibles riesgos y limitaciones que han en dichos procesos políticos. Así, con estas ideas en mente, me detengo ahora en los últimos objetivos planteados en la introducción de este trabajo.

Como expuse en la "Introducción" de esta tesis, el tema de la etnicidad maya ha sido ampliamente abordado por diversos estudiosos. También señalé que es un tema controvertido, sobre el cual no existe acuerdo en torno a si existe o no una etnicidad maya en Yucatán. Los estudios que postulan que sí existe una identidad étnica maya en el estado han documentado cómo dicha identidad se basa en una serie de diacríticos, tales como la lengua, la milpa, los rituales, la comunidad de origen, entre otros. En esta investigación he seguido una ruta un tanto distinta y espero que este estudio contribuya al conocimiento de la etnicidad como un fenómeno eminentemente político, en el que actores individuales y colectivos que se identifican como mayas plantean una serie de demandas y reivindicaciones en nombre del Pueblo Maya.

No basta con señalar que la etnicidad no es una esencia o algo natural y que es una construcción histórica, sino que hay que preguntarnos, ¿quiénes son los actores individuales y colectivos étnicos y en qué campos, arenas y procesos se expresa la etnicidad maya, es decir, se llevan cabo las reivindicaciones del Pueblo Maya? En esta investigación pudimos ver que los principales actores mayas eran promotores culturales, escritores, intelectuales y profesionistas; que al inicio de sus vidas, dichos actores negaban o se sentían avergonzados de sus orígenes étnicos pero, gracias a procesos de movilidad social ascendente y al control de ciertos recursos, transformaron la negación y vergüenza étnica en afirmación y exigencia de reconocimiento de su diferencia. 
¿En qué campos, arenas y procesos tienen lugar las reivindicaciones del Pueblo Maya? Si bien en un inicio me propuse estudiar un solo campo, el jurídico, por considerarlo prioritario en las reivindicaciones étnicas en Yucatán, muy pronto pude advertir la importancia de otros ámbitos, como el festivo y el de la emergencia de jóvenes mayas.

En cuanto al campo jurídico, una de las principales tesis de este trabajo es que no podemos entender la "Ley para la Protección de los Derechos de la Comunidad Maya del Estado de Yucatán" como un producto unilateral, ya sea de "arriba" (del Estado) o de "abajo" (de las organizaciones mayas). Más bien, en tanto proceso político, fue producto de un campo político conformado por diversos actores, tanto mayas como no mayas. Sin embargo, en términos del análisis del poder, dicha Ley parece beneficiar más al estado que a la población maya de Yucatán. Lejos de avanzar en la construcción de una sociedad intercultural, parece que dio un paso atrás hacia el viejo indigenismo integracionista al definir una instancia estatal que atenderá los problemas de la "comunidad maya" del estado. El amplio y diverso abanico de demandas planteadas por organizaciones mayas, académicos, organizaciones de la sociedad civil y ciudadanos interesados en el tema apenas fue escuchado e incorporado en la Ley. Todo esto es aún más grave si consideramos, con Krotz (2015:196), "que el Estado de Derecho parece cada vez más debilitado en México". ¿Qué impacto tendrá realmente dicha Ley en el bienestar de la población maya de Yucatán? Aún no lo sabemos. Además del fortalecimiento de la institución indigenista del Estado, el Indemaya, la Ley postula dos principales elementos: la elaboración de un Registro de comunidades mayas del estado y la creación de la figura de los "Jueces Mayas", que no es más que una reinterpretación de los jueces de paz. A partir de estos elementos, resulta difícil vislumbrar que la Ley tendrá un impacto positivo para los mayas de Yucatán y para la construcción de una sociedad con un verdadero diálogo y equidad intercultural.

Lo anterior parece confirmar la tesis de Teresa Sierra, Aída Hernández y Rachel Sieder (2013) sobre el agotamiento del Estado multicultural en México. No tengo los elementos para sostener si un "Estado penal" está sustituyendo a dicho Estado multicultural en Yucatán, pero lo que sí puedo afirmar es que las limitaciones de la legislación yucateca no son obstáculo para que los actores étnicos sigan planteando sus 
demandas en términos de derechos humanos. Esto lo pudimos apreciar en el caso del Festival Maya Independiente Cha'anil Kaaj. Éste festival cuestionó la política cultural del Gobierno del Estado de Yucatán que emplea a la cultura maya, o más bien, a cierta idea de ella, como un atractivo mercantil y turístico. A pesar de las críticas de Cha'anil Kaaj, el Gobierno del Estado no parece haber cambiado dicha política cultural. Ha continuado celebrando el Festival Internacional de la Cultura Maya (FICM) y el presidente ejecutivo de dicho festival, Jorge Esma Bazán, calificó a la edición de 2015, dedicada al tema de la ciencia, como "el festival más vibrante, más importante y más trascendente en la historia cultural artística contemporánea de Yucatán”. En una entrevista con La Jornada Maya, Esma declaró que es el festival que ha tenido mayor participación por parte del público y que la edición de 2016 estará dedicada al tema de la lengua maya.

Por su parte, si bien el colectivo Yóol Kaaj sí ha celebrado el Festival Maya Independiente Cha'anil Kaaj en 2014 y 2015, lo cierto es que, por cuestiones organizativas, ha perdido visibilidad: en 2014 no se llevó a cabo la clausura programada y en 2015 el festival se realizó de manera dispersa en diversas fechas del año. En sus dos últimas ediciones no ha tenido la presencia que tuvo en su primera edición en 2013, a tal grado que varios editorialistas se han preguntado por qué no se ha vuelto a celebrar un festival maya independiente como respuesta al gubernamental FICM.

En este momento no puedo concluir mucho sobre las dos últimas ediciones de Cha'anil Kaaj. Sí puedo destacar cómo en su primera edición el colectivo organizador en el cual participé- pudo visibilizar una concepción de la cultura maya viva y contemporánea que contrastaba con la exaltación de la civilización maya antigua del FICM. En su discurso utópico, Cha'anil Kaaj retomaba elementos discursivos del EZLN, como en la oposición entre el "festival del pueblo" y el festival del "mal gobierno". Estas oposiciones constituían de manera performativa la etnicidad maya y la idea del Pueblo Maya. Sin embargo, en los hechos pudimos apreciar que sí había colaboraciones entre Yóol Kaaj y el gobierno a nivel municipal, especialmente en aquellos donde gobernaban el PAN y el PRD. Entre las preguntas que quedan pendientes es si Cha'anil Kaaj ha sido una plataforma para que ciertos actores logren mayor proyección política o si logrará enraizarse más en las diversas comunidades del estado. En todo caso, no se tratan de posibilidades excluyentes. 
Por último, uno de los fenómenos que ha llamado la atención a los estudiosos de los movimientos indígenas y reivindicaciones étnicas en América Latina es la emergencia de jóvenes indígenas como actores políticos. En consonancia con dichos estudios, en esta investigación analicé cómo jóvenes que se identifican como mayas plantean nuevas formas de indigeneidad, de ser mayas, y cómo presentan cierta continuidad con las demandas de generaciones anteriores de actores mayas — su demanda principal sigue siendo la lengua maya - pero también cómo plantean algunas demandas nuevas, sobre todo las que tienen que ver con tecnologías de la información y comunicación. Ciertamente, estos actores son un sector minoritario que contrastan con la mayoría de jóvenes indígenas que viven en condiciones precarias en Yucatán. No puedo ocultar mis simpatías personales hacia ellos y hacia sus diversos proyectos de reivindicación de su lengua y cultura. Pero, en términos políticos, queda pendiente profundizar en el análisis de en qué medida sus actitudes no confrontativas con el poder resultan conservadoras o pueden dar lugar a cambios mayores en términos de la construcción de una sociedad intercultural.

Quisiera finalizar con dos reflexiones de carácter epistemológico, pero también ético, con respecto al estudio antropológico del llamado "problema indígena". Las poblaciones indígenas en México han sido las fuentes de alteridad por excelencia de la disciplina $y$, ciertamente, los enfoques en torno a ella han cambiado a través de los años. No obstante, considero que persisten hasta la fecha dos actitudes epistemológicas que pueden resultar perjudiciales para la investigación. Así, la primera reflexión tiene que ver con el énfasis en la continuidad entre la población indígena prehispánica y la contemporánea. El peligro de esta actitud epistemológica es que conduzca al investigador a fijarse únicamente en los elementos sociales y culturales prehispánicos que, como las supervivencias tylorianas, aún existen en el presente. ¿Acaso existe una actitud epistemológica, un ethos o un "canon etnográfico" (Pitarch 2008) que dicta que lo que vale la pena investigar de las poblaciones indígenas es lo prehispánico que aún persiste?, ¿eso le da legitimidad al estudio?, ¿qué perdemos de vista cuando sólo nos enfocamos en lo que del pasado aún existe en el presente? Desde luego, no me pronuncio a favor de un presentismo y en contra de la investigación histórica; todo lo contrario. La pregunta que queda pendiente es: ¿cómo podemos investigar de manera histórica y etnográfica las 
problemáticas indígenas mexicanas sin el canon etnográfico que dicta que lo valioso a estudiar es lo que persiste de tiempos prehispánicos? En esta tesis he analizado el fenómeno de la etnicidad no como una persistencia del pasado entre algunos sectores indígenas contemporáneos, sino como los procesos y prácticas políticas actuales que buscan la construcción de una sociedad más justa e intercultural. Acaso para superar el canon etnográfico "continuista" con el pasado haya que atender a otra reflexión epistemológica y ética.

Diversos actores de esta investigación mostraron cómo pueden ser mayas sin ser "tradicionalistas" o enfatizar lo que del pasado prehispánico persiste en ellos. Es decir, su diferencia no tiene que ver únicamente con una diferencia del pasado. En este orden de ideas, el segundo problema epistemológico que deseo destacar es que, a menudo, las poblaciones indígenas en México son pensadas y concebidas como Diferencia cultural, con d mayúscula, es decir, como colectivos radicalmente distintos a los no indígenas. Los fundamentos de esa Diferencia cultural radical y fetichizada pueden ser varios: una lengua, una cosmovisión, una forma de organización política, económica, de parentesco o una cultura distinta. A pesar de los ya lugares comunes sobre los efectos de la globalización, la urbanización, la migración y las nuevas tecnologías de información y comunicación entre las poblaciones indígenas, suele persistir un interés en la continuidad de dicha Diferencia, o cómo a partir de dicha Diferencia son apropiados, reinterpretados y resignificados los elementos culturales no indígenas. Desde luego, no encuentro nada desdeñable en dicho interés, pero sí deseo advertir el peligro de pensar en la diferencia de manera radical, fetichizada, con d mayúscula, y pasar por alto los elementos comunes y compartidos entre los indígenas y no indígenas. Acaso a lo largo de su historia la antropología se ha esmerado en visualizar y entender la Diferencia con d mayúscula: como un estadio en la evolución humana, como elemento de una cultura o configuración cultural, como una serie de funciones que satisfacen necesidades humanas universales, como expresión de estructuras universales inconscientes o de tramas de significado y sentido, como formas de conocimiento, construcciones históricas y discursivas vinculadas con el poder o, más recientemente, como ontologías o modos de ser en el mundo. 
Debemos pensar la diferencia, sí, pero hacerlo con d minúscula, pues ello nos puede ayudar a comprender mejor lo que nos hace distintos de quienes consideramos que son diferentes de nosotros, pero también nos permite a observar y comprender nuestras semejanzas y elementos compartidos; del mismo modo, acaso nos pueda ayudar a entender mejor las diferencias entre quienes consideramos que son iguales a nosotros. Entender la diferencia con d minúscula puede contribuir a la tolerancia y comprensión mutua de la humanidad. Termino con unas palabras de Seyla Benhabib (2006:16) plasmadas en su libro Las reivindicaciones de la cultura - el cual me inspiró para titular esta tesis-: "Las reivindicaciones de las culturas para mantener su individualidad frente a estas interdependencias [globales] pueden hacerse realidad sólo a través de diálogos riesgosos con otras culturas, que pueden llevar a la separación y la controversia, así como a la comprensión y el aprendizaje mutuo". 


\section{BIBLIOGRAFÍA}

Abélès, Marc

2008

Política de la supervivencia. Buenos Aires: Eudeba.

Adams, Richard N.

1983 [1975] Energía y estructura. Una teoría del poder social. México: Fondo de Cultura Económica.

1995 Etnias en evolución social. Estudios de Guatemala y Centroamérica. México: Universidad Autónoma Metropolitana.

2005 Etnicidad e igualdad en Guatemala, 2002. Santiago: Naciones Unidas/Comisión Económica para América Latina y el Caribe/Deutsche Gesellschaft für Technische Zusammenarbeit.

Agamben, Giorgio

1998 [1995] Homo Sacer. El poder soberano y la nuda vida. Valencia: Pre-Textos.

Aguirre Beltrán, Gonzalo

1989 [1965] “Introducción”. Julio de la Fuente, Relaciones interétnicas: 9-21. México: Instituto Nacional Indigenista/Consejo Nacional para la Ciencia y las Artes.

1991a [1953] Formas de gobierno indígena. México: Fondo de Cultura Económica.

1991b [1967] Regiones de refugio. El desarrollo de la comunidad y el proceso dominical en mestizoamérica. México: Fondo de Cultura Económica/Universidad Veracruzana/Gobierno del Estado de Veracruz/Instituto Nacional Indigenista. 
Alcalá Campos, Raúl

2009

“El movimiento indígena y el papel del intelectual”. En: Destiempos.com, año 3, núm. 18, pp. 304-326.

Alonzo Caamal, Bartolomé

1982 Los mayas en la política, a través de Chichimiláh, Yucatán. México: Programa de Formación Profesional de Etnolingüistas/Secretaría de Educación Pública/Instituto Nacional Indigenista/Centro de Investigaciones y Estudios Superiores en Antropología Social.

1993 "Los mayas en la conciencia nacional". En: Arturo Warman y Arturo Argueta, eds., Movimientos indígenas contemporáneos en México, pp. 3561. México: Universidad Nacional Autónoma de México/Miguel Ángel Porrúa.

2008 "Perspectiva de la nueva Ley para las organizaciones no gubernamentales promotoras de la lengua maya en Yucatán”. En: Esteban Krotz, coord., Yucatán ante la Ley General de Derechos Lingüisticos de los Pueblos Indigenas, pp. 201-215. México: Instituto Nacional de Lenguas Indígenas/Universidad de Oriente.

Amselle, Jean-Loup

2010

"De la deconstrucción de la etnia a la conexión de las culturas: un itinerario intelectual". En: Cristophe Giudicelli, ed., Fronteras movedizas. Clasificaciones coloniales y dinámicas socioculturales en las fronteras americanas, pp. 21-57. México: El Colegio de Michoacán/Centro de Estudios Mexicanos y Centroamericanos/Ambassade de France au Mexique.

s.f. "De la India a las Américas indias”. Documento facilitado por su autor.

Anderson, Benedict

2007 [1983] Comunidades imaginadas. Reflexiones sobre el origen y la difusión del 
nacionalismo. México: Fondo de Cultura Económica.

Angulo López, Geofredo

2008 "Constitución y derechos de la etnia maya en Yucatán”. En: Revista de la Universidad Autónoma de Yucatán, núms. 245-246, pp. 3-12.

Appadurai, Arjun

2001 [1996] La modernidad desbordada. Dimensiones culturales de la globalización. Buenos Aires: Trilce, Fondo de Cultura Económica.

Armstrong-Fumero, Fernando

2009 "Old Jokes and New Multiculturalisms: Continuity and Change in Vernacular Discourse on the Yucatec Maya Language". En: American Anthropologist 111(3):360-372.

Austin, John L.

1990 [1962] Cómo hacer cosas con palabras. Barcelona: Paidós.

Ayora Díaz, Steffan Igor

2012 Foodscapes, Foodfields, and Identities in Yucatán. Nueva York: Berghahn.

Báez Landa, Mariano, Franck Galbrun y Sergio Chí Silva

2007 Juventud maya. Problemas y retos en Yucatán. CIESAS/FCA-UADY. 23:42 mins.

Báez Landa, Mariano y José Manuel Flores López

2008 "Yucatán, los círculos de la marginación”. En: Temas Antropológicos, vol. 30, núm. 1, pp. 89-113.

Balandier, Georges 
1994 El poder en escenas. De la representación del poder al poder de la representación. Barcelona: Paidós.

Baños, Othón

1989 Yucatán: ejidos sin campesinos. Mérida: Universidad Autónoma de Yucatán.

2000 “La península de Yucatán en la ruta de la modernidad (1970-1995)”. En:

Revista Mexicana del Caribe, vol. 5, núm. 9, pp. 164-190.

Baqueiro Anduze, Oswaldo

1937 La maya y el problema de la cultura indígena. Mérida: Edición de autor.

Barrera Vásquez, Alfredo

1949 "La historia de los mayas de Yucatán a través de sus propias crónicas". En: Sol Tax, ed., Selected papers of the XXIXth International Congress of Americanists, pp. 119-122. Chicago: The University of Chicago Press.

1986 [1942] "La cultura maya es patrimonio de los pueblos mayas, pero no todo el pueblo maya ha tenido cultura maya". En: ¿Lo ignoraba usted?, pp. 29-30. México: Secretaría de Educación Pública/Dirección General de Culturas Populares.

1987 "La literatura maya. Corta memoria sobre el tema". En: Los mayas: historia, literatura, teatro, danza, pp. 29-56. Mérida: Consejo Editorial de Yucatán.

2001 Coord., Diccionario Maya (Maya-Español; Español-Maya). México: Porrúa.

Barrera Vásquez, Alfredo y Silvia Rendón

1985 [1948] El Libro de los Libros de Chilam Balam. México: Fondo de Cultura Económica.

Barreto, José-Manuel 
"Introduction. Decolonial Strategies and Dialogue in the Human Rights Field”. En: José-Manuel Barreto, ed., Human Rights from a Third World Perspective: Critique, History and International Law, pp. 1- Cambridge Scholars Publishing.

Barth, Fredrik

1976 [1969] "Introducción”. En: Fredrik Barth, comp., Los grupos étnicos y sus fronteras, pp. 9-49. México: Fondo de Cultura Económica.

Bartolomé, Miguel

1988 La dinámica social de los mayas de Yucatán: pasado y presente de la situación colonial. México: Instituto Nacional Indigenista.

Bartra, Roger

1997

"Violencias indígenas", La Jornada Semanal, 31 de agosto.

Bauman, Richard

1975

"Verbal art as performance". En: American Anthropologist, vol. 77, núm.

2, pp. 290-311

Bell, Catherine

1998

"Performance". En: Mark Taylor, ed., Critical Terms for Religious

Studies, pp. 205-224. Chicago/Londres: The University of Chicago Press.

Bell, Daniel

1991 El Advenimiento de la sociedad post-industrial. Madrid: Alianza.

Bengoa, José

2000

La emergencia indígena en América Latina. Santiago: Fondo de Cultura Económica. 
Benhabib, Seyla

2006 [2002] Las reivindicaciones de la cultura. Igualdad y diversidad en la era global. Buenos Aires: Katz.

Benjamin, Walter

2012 "El narrador. Reflexiones sobre la obra de Nikolái Leskov". En: Escritos franceses, pp. 239-264. Buenos Aires: Amorrortu.

Bentley, G. Carter

1987 "Ethnicity and Practice". En: Comparative Studies in Society and History, vol. 29, núm. 1, pp. 24-55.

Berlin, Isaiah 2006 [1955] Contra la corriente. Ensayos sobre historia de las ideas. México: Fondo de Cultura Económica.

Bhabha, Homi

2002 El lugar de la cultura. Buenos Aires: Manantial.

Biehl, Joâo y Peter Locke

2010 "Deleuze and the Anthropology of becoming". En: Current Anthropology, vol. 51, núm. 3, pp. 317-351.

Bloch, Ernst

1980 "Fragmentos sobre la utopía”. En: Esteban Krotz, Utopía, pp. 257-269. México: Universidad Autónoma Metropolitana-Iztapalapa.

Boellstorff, Tom

2008 Coming of Age in Second Life. An Anthropologist Explores the Virtually Human. Princeton and Oxford: Princeton University Press.

Bonfil Batalla, Guillermo 
1972 "El concepto de indio en América: una categoría de la situación colonial”. En: Anales de Antropología, vol. IX, pp. 105-124.

1981 Utopía y revolución: el pensamiento político contemporáneo de los indios en América Latina. México: Nueva Imagen.

1987 México profundo. Una civilización negada. México: Centro de Investigaciones y Estudios Superiores en Antropología Social/Secretaría de Educación Pública.

1991 "Lo propio y lo ajeno: una aproximación al problema del control cultural”. En: Pensar nuestra cultura, pp. 58-67. México: Alianza.

2006 [1962] Diagnóstico sobre el hambre en Sudzal, Yucatán: un ensayo de antropología aplicada. México: Centro de Investigaciones y Estudios Superiores en Antropología Social/Universidad Autónoma Metropolitana/Universidad Iberoamericana.

Bourdieu, Pierre

1988 [1986] "Espacio social y poder simbólico”. En: Cosas dichas, 127-142. México: Gedisa.

2001 [1985] "El lenguaje autorizado: las condiciones sociales de la eficacia del discurso ritual”. En: ¿Qué significa hablar? Economía de los intercambios lingüísticos, pp. 67-77. Madrid: Akal.

2003 El oficio de científico. Ciencia de la ciencia y reflexividad. Barcelona: Anagrama.

2009 [1980] El sentido práctico. México: Siglo XXI.

2014 Sobre el Estado: cursos en el Collège de France (1989-1992). Barcelona: Anagrama.

Bourdieu, Pierre, Jean-Claude Chamboredon y Jean-Claude Passeron 1975 El oficio de sociólogo. Presupuestos epistemológicos. México: Siglo XXI.

Bourgois, Philippe 
"El poder de la violencia en la guerra y en la paz: lecciones pos-guerra fría de El Salvador". En: Apuntes de Investigación del CECYP, núm. 8, pp. 7398.

Bracamonte y Sosa, Pedro

1994

La memoria enclaustrada. Historia indígena de Yucatán 1750-1915. México: Centro de Investigaciones y Estudios Superiores en Antropología Social/Instituto Nacional Indigenista.

2001 La conquista inconclusa de Yucatán. Los mayas de la montaña, 15601680. Mérida: Centro de Investigaciones y Estudios Superiores en Antropología Social.

2010

Tiempo cíclico y vaticinios. Ensayo etnohistórico sobre el pensamiento maya. México, DF: Centro de Investigaciones y Estudios Superiores en Antropología Social, Miguel Ángel Porrúa.

Bracamonte y Sosa, Pedro y Jesús Lizama Quijano 2006

Tocando fondo. Resultados básicos de la encuesta sobre marginalidad, pobreza e identidad del pueblo maya, EMPIMAYA 2004. México: Centro de Investigaciones y Estudios Superiores en Antropología Social.

Bracamonte y Sosa, Pedro, Jesús Lizama Quijano y Gabriela Solís Robleda 2011 Un mundo que desaparece. Estudio sobre la región maya peninsular. México, DF: Centro de Investigaciones y Estudios Superiores en Antropología Social/Comisión Nacional para el Desarrollo de los Pueblos Indígenas.

Burguete Cal y Mayor, Araceli

2013

"Constitutional Multiculturalism in Chiapas: Hollow Reforms that Nullify Autonomy Rights". En: Todd A. Eisenstadt, Michael S. Danielson, Moisés Jaime Bailón Corres y Carlos Sorroza Polo, eds., Latin America's 
Multicultural Movements. The Struggle Between Communitarianism, Autonomy, and Human Rights, pp. 40-66. Nueva York: Oxford.

Butler, Judith

2001 [1990] El género en disputa. El feminismo y la subversión de la identidad. México: Paidós-Universidad Nacional Autónoma de México.

Canché Moo, Vicente

2011

"Maya.glob.yuc, peripecias de un indígena en la ciudad". En: T'aan. Narrativa, Poesía y Dramaturgia, pp. 119-122. Mérida: Secretaría de Educación de Yucatán.

Cardoso de Oliveira, Roberto

1963 “Aculturación y ‘fricción’ interétnica”. En: América Latina, año 6, núm. 3, pp. 33-46.

2007

Etnicidad y estructura social. México: Centro de Investigaciones y Estudios Superiores en Antropología Social/Universidad Autónoma Metropolitana/Universidad Iberoamericana.

Carrillo Esau, Isaac

2011a U yóok'otilo'ob áak' ab/Danzas de la noche. México: Consejo Nacional para la Cultura y las Artes.

2011 b “U xíimbal eek’o’ob: U kíimil Yuum K’iin. U balts'amil ka’an”/“Paseo de los astros: la muerte del Sol. Dramaturgia del Cosmos". En: T'aan. Narrativa, Poesía y Dramaturgia pp. 132-157. Mérida: Secretaría de Educación de Yucatán.

Carrillo y Ancona, Crescencio

1937 [1881] Historia antigua de Yucatán. Mérida: Compañía Tipográfica Yucateca, S. A. 
Castañeda, Quetzil

1996

In the Museum of Maya Culture. Touring Chichén Itzá. Minneapolis: University of Minnesota Press.

2004 “‘No somos indígenas!’ Una introducción a la identidad maya de Yucatán”. En: Juan A. Castillo Cocom y Quetzil Castañeda, eds. Estrategias identitarias. Educación y la antropología histórica en Yucatán, pp. 1-32. Mérida: Universidad Pedagógica Nacional/The Open School of Ethnography and Anthropology/Secretaría e Educación Pública.

Castillo Cocom, Juan

2005

“"It was simply their word' Yucatec Maya PRInces in YucaPAN and the politics of respect”. En: Critique of Anthropology, vol. 25, núm. 2, pp. 131-155.

Castillo Cocom, Juan A. y Quetzil Castañeda, eds. 2004 Estrategias identitarias. Educación y la antropología histórica en Yucatán. Mérida: Universidad Pedagógica Nacional/The Open School of Ethnography and Anthropology/Secretaría e Educación Pública.

Castro-Gómez, Santiago

2010

"Michel Foucault: colonialismo y geopolítica". En: Ileana Rodríguez y Josebe Martínez, eds., Estudios transatlánticos postcoloniales I. Narrativas comando/sistemas mundos: colonialidad/modernidad, pp. 271292. Barcelona: Anthropos/Universidad Autónoma MetropolitanaIztapalapa.

Chan, Gener 2006

“Maaya K'a ak'/Fuego Maya". En: Terceros Juegos Literarios Universitarios, pp. 91-122. Mérida: Universidad Autónoma de Yucatán.

Clendinnen, Inga 
2003 [1986] Ambivalent Conquests. Maya and Spaniards in Yucatan, 1517-1570. Cambridge: Cambridge University Press.

Cohen, Abner

1974

Two Dimensional Man. An Essay on the Anthropology of Power and Symbolism in Complex Society. Berkeley/Los Angeles: University of California Press.

1979

"Antropología política: el análisis del simbolismo en las relaciones de poder". En: J.R. Llobera, comp., Antropología política, pp. 55-82. Barcelona: Anagrama.

Coll, Tatiana

2015

"Las Normales Rurales: noventa años de lucha y resistencia". En: El Cotidiano, núm. 189, pp. 83-94.

Comaroff, Jean y John L. Comaroff

1991 Of Revelation and Revolution. Christianity, Colonialism and Consciousness in South Africa. Volume One. Chicago: The University of Chicago Press.

1992 "Of totemism and ethnicity". En: Ethnography and the historical imagination, pp. 49-67. Boulder/San Francisco/Oxford: Westview Press.

2009 [2004] Violencia y ley en la poscolonia: una reflexión sobre las complicidades Norte-Sur. Barcelona: Katz.

2012 Theory from the South. Or, How Euro-America is evolving toward Africa. Boulder: Paradigm.

Comaroff, John L. y Jean Comaroff 2009 Ethnicity, Inc. Chicago: The University of Chicago Press, Chicago.

Comaroff, John L. 
1996

"Ethnicity, nationalism, and the politics of differencie in an age of revolution". En: Edwin N. Wilmsen y Patrick A. McAllister, eds., The Politics of Differencie: Ethnic Premises in a World of Power, pp. 162-183. Chicago: University of Chicago Press.

2010 "The end of anthropology, again: on the future of an in/discipline". En: American Anthropologist, vol. 112, núm. 4, pp. 524-538.

Cunill, Caroline

2008 "La alfabetización de los mayas yucatecos y sus consecuencias sociales, 1545-1580”. En: Estudios de Cultura Maya, vol. 31, pp. 163-192.

2012a Los defensores de indios de Yucatán y el acceso de los mayas a la justicia colonial, 1549-1600. Mérida: Universidad Nacional Autónoma de México.

2012b "La negociación indígena en el Imperio ibérico: aportes a su discusión metodológica”. En: Colonial Latin American Review, vol. 21, núm. 3, pp. $391-412$.

Da Matta, Roberto

2002 Carnavales, malandros y héroes. Hacia una sociología del dilema brasileño. México: Fondo de Cultura Económica.

De la Cadena, Marisol y Orin Starn

"Indigeneidad: problemáticas, experiencias y agendas en el nuevo milenio”. En: Tabula Rasa, núm. 10, pp. 191-223.

De la Fuente, Julio

1989a [1964] Educación, antropología y desarrollo de la comunidad. México: Instituto Nacional Indigenista/Consejo Nacional para la Ciencia y las Artes.

1989b [1965] Relaciones interétnicas. México: Instituto Nacional Indigenista/Consejo Nacional para la Ciencia y las Artes.

De la Peña, Guillermo 
"La ciudadanía étnica y la construcción de 'los indios' en el México contemporáneo", Revista Internacional de Filosofia Política, núm. 6, pp. $116-140$.

Deleuze, Gilles

Foucault. Barcelona: Paidós.

1990 “Qué es un dispositivo?”. En: Varios autores, Michel Foucault, filósofo, pp. 155-163. Barcelona: Gedisa.

1995 "Deseo y placer". En: Archipiélago. Cuadernos de Crítica de la Cultura, núm. 23, pp. 12-20.

1999 [1990] "Postcriptum sobre las sociedades de control". Disponible en línea:

$<$ http://www.oei.org.ar/edumedia/pdfs/T10_Docu1_Conversaciones_Dele uze.pdf>

2008 [1967] Nietzsche y la filosofia. Barcelona: Anagrama.

Deleuze, Gilles y Félix Guattari

2010 [1980] Mil mesetas. Capitalismo y esquizofrenia. Valencia: Pre-Textos.

Depetris, Carolina

2009a "El viaje pintoresco de Frédéric de Waldeck”. En: Península, vol. 4, núm. 2, pp. 13-31.

2009b "Influencia del orientalismo en la explicación del origen del pueblo y ruinas mayas: las tribus perdidas de Israel y el caso Waldeck". En: Mexican Studies/Estudios Mexicanos, vol. XXV, núm. 2, pp. 227-246.

2010

"El orientalismo como episteme: Frédéric de Waldeck y las ruinas mayas". En: Humboldt im Netz, International Review for Humboldtian Studies, vol. XI, núm. 21, pp. 10-22.

Depetris, Carolina y Romina España 
“Oriente está en Yucatán. El viaje de Frédéric de Waldeck". En: Carolina Depetris, ed., Viajeros por el mundo maya, pp. 21-32. Mérida: Centro Peninsular en Humanidades y Ciencias Sociales-Universidad Nacional Autónoma de México.

Derrida, Jacques

1996 “Firma, acontecimiento, contexto”. En: Márgenes de la filosofía, pp. 347372. Madrid: Cátedra.

1997

El monolingüismo del otro o la prótesis de origen. Buenos Aires: Manantial.

Díaz, Floriberto

2007 Escrito: comunalidad, energía viva del pensamiento mixe. Ayuujktsea 'yen-ayuujkwenmaa 'ny- ayuujk mek 'ajten, (Sofía Robles y Rafael Cardoso, comps.). México: Universidad Nacional Autónoma de México.

Díaz-Bolio, José

"Mayas antiguos y modernos. Pruebas de identidad". Registro de Cultura Yucateca 1 (1): 5-20.

Díaz Cruz, Rodrigo

2002a "De los rituales extirpables a los rituales como actos de resistencia. Rituales indígenas a fines del milenio”. En: Guillermo de la Peña y Luis Vázquez León, coords., La antropología sociocultural en el México del milenio. Búsquedas, encuentros y transiciones, pp. 221-246. México: Instituto Nacional Indigenista/Consejo Nacional para la Cultura y las Artes/Fondo de Cultura Económica.

2002b "La creación de la presencia. Simbolismo y performance en grupos juveniles”. En: Alfredo Nateras, coord., Jóvenes, culturas e identidades urbanas, pp. 19-41. México: Miguel Ángel Porrúa/Universidad Autónoma Metropolitana-Iztapalapa. 
"Anomalías y arrogancias de las identidades colectivas". En: Gustavo Leyva, coord., Política, identidad y narración, pp. 293-318. México: Universidad Autónoma Metropolitana-Iztapalapa/Miguel Ángel Porrúa. "La celebración de la contingencia y la forma. Sobre la antropología de la performance”. En: Nueva Antropología, vol. 21, núm. 69, pp. 33-59.

2009

"Sobre la performatividad del género. Judith Butler o la crítica a una metafísica de la sustancia”. En: Miguel Ángel Aguilar, Eduardo Nivón, María Ana Portal y Rosalía Winocur, coords., Pensar lo contemporáneo: de la cultura situada a la convergencia tecnológica, pp. 180-194. Barcelona: Anthropos/Universidad Autónoma Metropolitana.

Los lugares de lo político, los desplazamientos del símbolo. Poder y simbolismo en la obra de Victor W. Turner. México: Gedisa/Universidad Autónoma Metropolitana.

Dietz, Gunther

2005

"Del indigenismo al zapatismo: la lucha por una sociedad mexicana multiétnica". En: Nancy Postero y Leon Zamosc, eds., La lucha por los Derechos Indígenas en América Latina, pp. 53-128. Quito: Abya-Yala.

Douglas, Mary

1973

Pureza y Peligro. Madrid: Siglo XXI.

Duarte Duarte, Ana Rosa

2013-2014 "Las autonomías de los pueblos mayas de Yucatán y su silencio ante las políticas de asimilación y la legislación de sus derechos”. En: Pueblos y Fronteras Digital, v. 8, n. 16, p. 256-281.

Durkheim, Émile y Marcel Mauss

1971 [1903] “De ciertas formas primitivas de clasificación”. En: Marcel Mauss, Institución y culto. Representaciones colectivas $y$ diversidad de civilizaciones. Obras II, pp. 13-73. Barcelona: Barral. 
Durkheim, Émile

2000 [1912] Las formas elementales de la vida religiosa. México: Colofón

Dussel, Enrique

2004 "Sistema mundo y transmodernidad". En: Saurabh Dube Ishita Banerjee y Walter Mignolo, eds., Modernidades coloniales, pp. 201-226. México: El Colegio de México.

200620 tesis de política. México: Siglo XXI/Centro de Cooperación Regional para la Educación de Adultos en América Latina y el Caribe.

Duve, Thomas

2013 "European Legal History - Global Perspectives". En: Max Planck Institute for European Legal History Research Paper Series No. 2013-06, pp. 1-24.

Elbez, Melissa

2013 "La Fin du monde racontée à nos enfants". En: Tohu Bohu, núm. 17, julio de 2013.

Epstein, A.L.

$1978 \quad$ Ethos and Identity. Three Studies in Ethnicity. Londres: Tavistock.

Equipo Indignación

2014 Rebelión y resistencia del Pueblo Maya. Chablekal: Equipo Indignación.

Escobar, Arturo

2003

“"Mundos y conocimientos de otro modo'. El programa de investigación de modernidad/colonialidad latinoamericano". En: Tabula Rasa, núm. 1, pp. 51-86. 
Una minga para el postdesarrollo: lugar, medio ambiente y movimientos sociales en las transformaciones globales. Lima: Programa Democracia y Transformación Social/Universidad Nacional Mayor de San Marcos.

España Paredes, Romina

2013 "Configuraciones de la utopía nacional yucateca en la literatura de viaje de Justo Sierra O'Reilly". En: Arturo Taracena, ed., Miradas regionales. Las regiones y la idea de nación en América Latina, siglos XIX y XX, pp. 187214. Mérida: Centro Peninsular en Humanidades y Ciencias SocialesUniversidad Nacional Autónoma de México.

2015 "El espacio utópico en los relatos de viaje por Yucatán de Alice Dixon Le Plongeon". En: Carolina Depetris y Adrián Curiel Rivera, eds., Geografias literarias de América, pp. 181-210. Mérida: Universidad Nacional Autónoma de México.

Evans-Pritchard, E.E.

1987 "La realeza divina de los shilluk del Sudán". En: Josep Llobera, comp.., Antropología política, pp. 297-315. Barcelona: Anagrama.

1997 Los nuer. Barcelona: Anagrama.

2010 "Los nuer del sur de Sudán”. En: Meyer Fortes y E.E. Evans-Pritchard, eds., Sistemas políticos africanos, pp. 405-437. México: Centro de Investigaciones y Estudios Superiores en Antropología Social/Universidad Autónoma Metropolitana/Universidad Iberoamericana.

Fabian, Johannes

1983 Time and the Other: How Anthropology makes its object. Nueva York: Columbia University Press.

Power and Performance. Ethnographic Explorations through Proverbial Wisdom and Theater in Shaba, Zaire. The University of Wisconsin Press.

Fabricant, Nicole y Nancy Postero 
“Performing the 'Wounded Indian': A New Plataform of Democracy and Human Rights in Bolivia's Autonomy Movement”. En: Identities, en prensa.

Fallaw, Ben

“Cárdenas and the Caste War that Wasn't: State Power and Indigenismo in Post-Revolutionary Yucatán”. En: The Americas, vol. 53, núm. 4, pp. 551577.

2008 "Bartolomé García Correa and the politics of Maya identity in postrevolutionary Yucatán, 1911-1933”. Ethnohistory 55 (4): 553-578.

Farmer, Paul 1996

"On suffering and structural violence: a view from below". En: Daedalus, vol., 125, núm. 1, pp. 261-283.

Farriss, Nancy

1992 La sociedad maya bajo dominio colonial. La empresa colectiva de supervivencia. Madrid: Alianza.

Favre, Henri

1998 [1996] El indigenismo, México, Fondo de Cultura Económica.

Feenberg, Andrew

2010 Between Reason and Experience. Essays in Technology and Modernity. Cambridge y Londres: The MIT Press.

Feixa, Carles

1998 De jóvenes, bandas y tribus. Antropología de la juventud. Barcelona: Ariel.

Ferguson, James y Akhil Gupta 
"Spatializing States: Toward and Ethnography of Neoliberal Governmentality". En: American Ethnologist, vol. 29, núm. 4, pp. 9811002 .

Fortes, Meyer y E.E. Evans-Pritchard, eds.

2010 Sistemas políticos africanos. México: Centro de Investigaciones y Estudios Superiores en Antropología Social/Universidad Autónoma Metropolitana/Universidad Iberoamericana.

Foucault, Michel

1982 Las palabras y las cosas. Una arqueología de las ciencias humanas. México: Siglo XXI.

1988 "El sujeto y el poder". En: Revista Mexicana de Sociología, vol. 50, núm. 3, pp. 3-20.

2005 Vigilar y castigar. Nacimiento de la prisión. México: Siglo XXI.

2006 Seguridad, territorio, población. Buenos Aires: Fondo de Cultura Económica.

$2007 \quad$ Nacimiento de la biopolítica. Curso en el Collége de France (1978-1979). Buenos Aires: Fondo de Cultura Económica.

2009 Historia de la sexualidad. 1. La voluntad de saber. México: Siglo XXI.

2012 Historia de la locura en la época clásica. México: Fondo de Cultura Económica.

Fraser, Nancy

"From Redistribution to Recognition? Dilemmas of Justice in a 'Postsocialist' Age". En: Justice Interruptus. Critical Reflections on the "Postsocialist" Condition, pp. Nueva York: Routledge.

Frazer, James

1980 La rama dorada. México: Fondo de Cultura Económica. 
Friedrichsthal, Emanuel von

1994 [1841] "Sobre los que construyeron los edificios de Yucatán, y su antigüedad". En: Justo Sierra O’Reilly, Los indios de Yucatán. Consideraciones históricas sobre la influencia del elemento indígena en la organización social del país. Mérida: Universidad Autónoma de Yucatán.

2006 [1841] “Los monumentos de Yucatán”. Apéndice de Taracena y Sellen 2006.

Fukuyama, Francis

1992

El fin de la historia y el último hombre. Barcelona: Planeta.

Gabbert, Wolfgang

2004

Becoming Maya. Ethnicity and social inequality in Yucatán since 1500. Tucson: University of Arizona Press.

Galtung, Johan

"Violence, peace, and peace research". En: Journal of Peace Research, vol. 6, núm. 3, pp. 167-191.

Gamio, Manuel

1982 [1916] Forjando patria. Pro-nacionalismo. México: Porrúa.

García Canclini, Néstor

2008 “Los jóvenes no se ven como el futuro: ¿serán el presente?”. En: Pensamiento Iberoamericano, núm. 3, 2a época, pp. 3-15.

García de Palacio, Diego

1983 [1576] Carta-relación de Diego García de Palacio a Felipe II sobre la provincia de Guatemala. 8 de marzo de 1576. México: Universidad Nacional Autónoma de México.

Geertz, Clifford 
Negara. The Theatre State in Nineteenth-Century Bali. Princeton University Press.

1987 “La política del significado”. En: La interpretación de las culturas, pp. 262-273. Barcelona: Gedisa

1994 "Centros, reyes y carisma: una reflexión sobre el simbolismo del poder”. En: Conocimiento local, pp. 147-171. Barcelona: Paidós.

Gellner, Ernest

2008 [1983] Naciones y nacionalismo. Madrid: Alianza.

Giddens, Anthony

2006 [1984] La constitución de la sociedad. Bases para la teoría de la estructuración. Buenos Aires: Amorrortu.

Gil Olmos, José

2015 Batallas de Michoacán. Autodefensas, el proyecto colombiano de Peña Nieto. México: Proceso.

Gómez, Magdalena

2013 "Los pueblos indígenas y la razón de Estado en México: elementos para un balance”. En: Nueva Antropología, vol. 26, núm. 78, pp. 43-62.

González Casanova, Pablo

1965 La democracia en México. México: Era.

Goodale, Mark

2006

"Reclaiming Modernity: Indigenous Cosmopolitanism and the Coming of the Second Revolution in Bolivia". American Ethnologist 33(4):634-649.

Greenwood, Davydd J. 
"Culture by the Pound: An Anthropological Perspective on Tourism as Cultural Commoditization". En: Valene Smith, ed., Hosts and Guests: The Anthropology of Tourism, pp. 171-185. Blackwell Publishers.

Gros, Frédéric 2007

Michel Foucault. Buenos Aires: Amorrortu.

Grube, Nikolai

2010

"Augurios y pronósticos en los códices mayas". Arqueología Mexicana 17(103):34-37.

Gudynas, Eduardo y Alberto Acosta

2011

"El buen vivir o la disolución de la idea de progreso". En: Mariano Rojas, ed., La medición del progreso y del bienestar: propuestas desde América Latina, pp. 103-110. México: Foro Consultivo Científico y Tecnológico.

Guss, David M.

2000 The Festive State. Race, Ethnicity, and Nationalism as Cultural Performance. University of California Press.

Gutiérrez Chong, Natividad

2001 [1999] Mitos nacionalistas e identidades étnicas: los intelectuales indígenas y el Estado mexicano. México: Consejo Nacional para la Cultura y las Artes/Instituto de Investigaciones Sociales-Universidad Nacional Autónoma de México.

Gutiérrez Estévez, Manuel

1992

“Mayas y 'mayeros': los antepasados como otros”. En: M. León Portilla, M. Gutiérrez Estévez, G. H. Gossen y J. J. Alva, eds., De palabra y obra en el Nuevo Mundo, Vol. 1, Imágenes interétnicas, Madrid: Siglo XXI, pp. 417-442. 
Guzmán Medina, Violeta

2005

Una nueva mirada hacia los mayas de Yucatán: identidad, cultura y poder, Mérida: Universidad Autónoma de Yucatán.

2010

"Juventud, pobreza y exclusión. Un diagnostico de los problemas de salud de los jóvenes mayas de Yucatán”. En: Medicina Social, vol. 5, núm. 2, pp. 128-134.

Habermas, Jürgen

1986 [1968] Ciencia y técnica como "ideología". Madrid: Tecnos.

Hale, Charles R.

2002 "Does multiculturalism menace? Governance, cultural Rights and the politics of identity in Guatemala". En: Journal of Latin american Studies, vol. 34, núm. 3, pp. 485-524.

Hardt, Michael y Antonio Negri

2002 [2000] Imperio. Barcelona: Paidós.

2012 [2011] Commonwealth. El proyecto de una revolución del común. Madrid: Akal.

Harvey, David

1989 La condición de la posmodernidad. Buenos Aires: Amorrortu.

Hervik, Peter

1999 Mayan people within and beyond boundaries. Amsterdam: Harwood Academic Publishers.

Holloway, John

2010 [2002] Cambiar el mundo sin tomar el poder: el significado de la revolución hoy. Buenos Aires: Herramienta. 
Honneth, Axel

1997

La lucha por el reconocimiento: por una gramática moral de los conflictos sociales. Barcelona: Crítica.

Reificación. Un estudio en la teoría del reconocimiento. Madrid: Katz.

Huddleston, Lee Eldridge

Origins of the American Indians. European concepts, 1492-1729. Austin: Institute of Latin American Studies-University of Texas Press.

Iturriaga Acevedo, Eugenia

2004 Estrategias indigenistas en el sur de Yucatán: relaciones interétnicas vistas a través del Centro Coordinador Indigenista de Peto. Tesis de maestría en ciencias antropológicas, Mérida, Facultad de Ciencias Antropológicas-Universidad Autónoma de Yucatán.

2010 “Racismo y representaciones: 'lo yucateco' en la televisión local”. En: Steffan Igor Ayora Diaz y Gabriela Vargas Cetina, eds., Representaciones culturales: imágenes e imaginación de lo yucateco, pp. 137165. Universidad Autónoma de Yucatán, Mérida.

2011

Las élites de la ciudad blanca: racismo, prácticas y discriminación étnica en Mérida, Yucatán. Tesis de doctorado en Antropología. México: Universidad Nacional Autónoma de México.

Iturriaga Acevedo, Eugenia y Valiana Aguilar

"Reflexiones sobre el racismo en el Twister: \#EsDeIndios". Ponencia presentada en la Mesa Panel: Racismo en el paisaje de la Península en el marco del Festival Maya Independiente Cha'anil Kaaj 2014. Mérida, Centro Peninsular en Humanides y Ciencias Sociales de la Universidad Nacional Autónoma de México, 23 de octubre de 2014.

Izquierdo y de la Cueva, Ana Luisa 
"Ley yucateca de derechos indígenas y el derecho internacional". Ponencia presentada en el VII Congreso Internacional de Mayistas, 8 a 14 de julio de 2007, Unidad Académica de Ciencias Sociales y Humanidades Mérida Yucatán.

Jackson, Jean E. y Kay Warren

2005 "Indigenous movements in Latin America, 1992-2004: controversies, ironies, new directions". En: Annual Review of Anthropology, vol. 34, pp. 549-573.

Johnson, Anne Warren

2014

“¿Qué hay en un nombre?’: una apologia del performance”. En: Alteridades, vol. 24, núm. 48, pp. 9-21.

Joseph, Gilbert M.

1992 Revolución desde afuera. Yucatán, México y los Estados Unidos, 18801924. México: Fondo de Cultura Económica.

Juris, Jeffrey

"Reflections on \#Occupy Everywhere: Social Media, Public Space, and Emerging Logics of Aggregation”. American Ethnologist 39(2):259-279.

Kertzer, David I.

1988 Ritual, Politics, and Power. New Haven: Yale University Press.

Klein, Naomi

2015 Esto lo cambia todo. El capitalismo contra el clima. México: Paidós.

Koyré, Alexandre 1982 [1957] Del mundo cerrado al universo infinito. México: Siglo XXI. 
Krotz, Esteban

1996

"Participación política indígena y pluralismo lingüístico". En: Revista de la Universidad Autónoma de Yucatán, núm. 196, enero/febrero/marzo 1996, pp. 26-30.

2001-2002 "El reconocimiento jurídico de los mayas de Yucatán"” En: Revista de la Universidad Autónoma de Yucatán, núms. 219-229, pp. 3-8.

2002 "La formulación de los derechos humanos como proceso de aprendizaje intercultural”. En: Devenires, vol. III, núm. 5, pp. 85-100.

2004a "Información reciente sobre la población indígena de la península de Yucatán: datos, contextos y reflexiones”. En: Economía Hoy, año 10, núm. 59, pp. 11-16.

2004b "Antropología, derechos humanos y diálogo intercultural”. En: Ciencias Sociales, vol. 103-104, núms. I-II, pp. 75-82.

2004c La otredad cultural entre utopía y ciencia. Un estudio sobre el origen, el desarrollo y la reorientación de la antropología. México: Fondo de Cultura Económica/Universidad Autónoma Metropolitana-Iztapalapa.

"Reforma legislativa y diálogo intercultural”. En: El Varejón, núm. 69, pp. 7-9.

“Consideraciones para una posible legislación reglamentaria en materia de Protección y el Fomento de los Derechos y la Cultura del Pueblo Maya en el Estado de Yucatán”. Documento facilitado por su autor.

2009 "La nación ante los derechos de sus pueblos indígenas: sobre cultura y relaciones interculturales desde una perspectiva antropológica". En: Estudios sobre las Culturas Contemporáneas, vol. XI, núm. 30, pp. 11-27.

2011 'La enseñanza de la antropología 'propia' en los programas de estudio en el Sur”. En: Alteridades, vol. 21, núm. 4, pp. 9-19.

2015a "Relaciones interculturales, la legislación sobre los derechos indígenas en Yucatán y los derechos humanos”. En: Esteban Krotz, ed., Sociedades mayas y derecho, pp. 185-201. San Cristóbal de Las Casas/Mérida: Programa de Investigaciones Multidisciplinarias sobre Mesoamérica y el 
Sureste/Instituto de Investigaciones Antropológicas-Universidad Nacional Autónoma de México/Universidad Modelo.

$2015 b \quad$ ed., Sociedades mayas y derecho. San Cristóbal de Las Casas/Mérida: Programa de Investigaciones Multidisciplinarias sobre Mesoamérica y el Sureste/Instituto de Investigaciones Antropológicas-Universidad Nacional Autónoma de México/Universidad Modelo.

Krotz, Esteban y Rodrigo Llanes

2011 "Concepciones antropológicas y segmentos poblacionales: elementos para la periodización de medio siglo de historia de una facultad de antropología mexicana”. En: Inventario Antropológico, vol. 9, pp. 377-396.

Kuhn, Thomas

2004 [1962] La estructura de las revoluciones científicas. México: Fondo de Cultura Económica.

Kuper, Adam

2001 [1999] Cultura. La versión de los antropólogos. Barcelona: Paidós.

2003 "The return of the native". En: Current Anthropology, vol. 44, núm. 3, junio 2003, pp. 389-402.

Lara Cebada, Cecilia

1996 "Etnicidad y conubración: lo maya en Chuburná". En: Cecilia Lara, ed., Identidades sociales en Yucatán, pp. 160-193. Mérida: Universidad Autónoma de Yucatán.

2004 "El papel del Jmeen en la construcción de la identidad étnica de Kanxoc". En: Temas Antropológicos, vol. 26, núms. 1-2, pp. 109-139.

Lash, Scott y John Urry

1987 The End of Organized Capitalism. Madison: University of Wisconsin. 
Latour, Bruno

2007 [1991] Nunca fuimos modernos. Ensayo de antropología simétrica. Buenos Aires: Siglo XXI.

2008 [2005] Reensamblar lo social. Una introducción a la teoría del actor-red. Buenos Aires: Manantial.

Le Breton, David

1995 [1990] Antropología del cuerpo y modernidad. Buenos Aires: Nueva Visión.

Leach, Edmund

1976 [1954] Sistemas políticos de la Alta Birmania: estudio sobre la estructura social kachin. Barcelona: Anagrama.

Leirana, Cristina 2001

Identidad étnica y políticas culturales: el auge de la literatura mayayucateca contemporánea. Tesis de Maestría en Ciencias Antropológicas. Mérida: Facultad de Ciencias Antropológicas.

Lentz, Mark

2008 "Los intérpretes generales de Yucatán: hombres entre dos mundos”. En: Estudios de Cultura Maya, vol. XXXIII, pp. 135-158.

2010 "El derecho a intérprete en los procesos legales: una lucha legal 16002009”. Documento facilitado por su autor.

Lévi-Strauss, Claude

1972 [1962] El pensamiento salvaje. México: Fondo de Cultura Económica.

Lewellen, Ted

1985 [1983] Antropología política. Barcelona: Bellaterra.

Ligorred, Francisco 
1990 Consideraciones sobre la literatura oral de los mayas modernos. México: Instituto Nacional de Antropología e Historia/Consejo Nacional para la Cultura y las Artes.

2000 "Literatura maya-yukateka contemporánea (tradición y futuro)". En: Mesoamérica, núm. 39, pp. 333-357.

Lizama Quijano, Jesús

2007

Estar en el mundo. Procesos culturales, estrategias económicas y dinámicas identitarias entre los mayas yucatecos. México: CIESAS/Miguel Ángel Porrúa.

“Ser maya en Yucatán. Apuntes sobre la dinámica identitaria”. En: Jesús Lizama, coord., El pueblo maya y la sociedad regional. Perspectivas desde la lingüística, la etnohistoria y la antropología, pp. 115-146. México: Centro de Investigaciones y Estudios Superiores en Antropología Social.

2012 Del pueblo a la urbe. El perfil maya de la blanca Mérida. México: Centro de Investigaciones y Estudios Superiores en Antropología Social.

Llanes Salazar, Rodrigo

2011 La mayanización de los mestizos yucatecos. La emergencia de la etnicidad maya en Yucatán. Tesina de maestría en ciencias antropológicas. México: Universidad Autónoma Metropolitana-Iztapalapa.

2014 "Lo propio y lo impropio: devenires de la antropología social mexicana contemporánea”. En: Nueva Antropología, vol. 27, núm. 81, pp. 95-122.

Loewe, Ronald

2011 Maya or Mestizo? Nationalism, Modernity, and its Discontents. University of Toronto Press.

López Cogolludo, Diego

1954 [1688] Historia de Yucatán. Campeche: Comisión de Historia-Talleres Gráficos 
del Gobierno Constitucional del Estado.

López Santillán, Ricardo

2011 Etnicidad y clase media. Los profesionistas mayas residentes en Mérida. Mérida: Universidad Nacional Autónoma de México/Instituto de Cultura de Yucatán.

Mackenzie, James

2010

"Of Networks and hierarchies: Pan-Mayanism and ethnic ambivalente in Guatemala”. En: Latin American and Caribbean Ethnic Studies, vol. 5, núm. 1, pp. 27-52.

Madison, Soyini y Judith Hamera

"Performance studies at the intersections". En: Soyini Madison y Judith Hamera, eds., The Sage Handbook of Performance Studies, pp. XI-XXV. Sage Publications, Thousand Oaks \& London.

Malesevic, Sinisa

2004

The sociology of ethnicity. Londres: Sage.

Marcus, George

"Etnografía en/del sistema mundo. El surgimiento de la etnografía multilocal". En: Alteridades, vol. 11, núm. 22, pp. 111-127.

Martínez, Juan Carlos

2012

La nueva justicia tradicional. Interlegalidad y ajustes en los campos jurídicos de Santiago Ixtayutla y Santa María Tlahuitoltepec. México: Universidad Autónoma Benito Juárez de Oaxaca/Konrad Adenauer Stiftung.

Marx, Karl 

XXI.

Marx, Karl y Frederich Engels

2008

"Manifiesto del Partido Comunista". En: Karl Marx y Frederich Engels, $E l$ papel del trabajo en la transformación del mono en hombre/Manifiesto del Partido Comunista/Ideología alemana, pp. 122-165. México: Colofón.

Mason Austin, Maude

2005

En Yucatán. México: Consejo Nacional para la Cultura y las Artes.

Mattiace, Shannan

2009

"Ethnic Mobilization hmong the Maya of Yucatán Today". En: Latin American and Caribbean Ethnic Studies, vol. 4, núm. 2, pp. 137-169.

2013 “Multicultural Reforms for Mexico's ‘Tranquil' Indians in Yucatán”. En: Todd A. Eisenstadt, Michael S. Danielson, Moisés Jaime Bailón Corres y Carlos Sorroza Polo, eds., Latin America's Multicultural Movements. The Struggle Between Communitarianism, Autonomy, and Human Rights, pp. 217-245. Nueva York: Oxford.

Mattiace, Shannan y Rodrigo Llanes 2015 "Reformas multiculturales para los mayas de Yucatán". En: Estudios Sociológicos, vol. 33, núm. 98, en prensa.

May May, Ismael

2010 El maya escrito a través de los medios de comunicación: localizando lo global. En Ricardo López Santillán, Coordinador, Etnia, lengua y territorio. El sureste ante la globalización. México: Universidad Nacional Autónoma de México. Pp. 211-235.

Miller, Daniel 
Monroy Gómez, Pablo

2013 Los derechos humanos de los mayeros: ¿una retórica más o derechos en acción? Tesis de maestría en Derechos Humanos y Democracia. México: Facultad Latinoamericana de Ciencias Sociales.

Montemayor, Carlos

2005

"Notas sobre la muerte en la narrativa maya actual". En: Acta Poética, vol. 26, núms. 1-2, pp. 577-592.

Moore, Sally Falk

1973 "Law and Social Change: The Semi-Autonomus Social Field as an Appropriate Subject of Study”. En: Law \& Society Review, vol. 7, pp. 719746.

1978 Law as Process. Londres: Routledge \& Kegan Paul.

Morales Valderrama, Carmen

1987

Los indigenas de Yucatán: a través de historiadores, viajeros y anticuarios del siglo XIX. Mérida: Maldonado.

Mossbrucker, Harald

1992

“"Etnia', 'cultura' y el impacto de la migración entre los mayas de Yucatán". En: América Indígena, vol. LII, núm. 4, pp. 187-214.

Mulhall, Stephen y Adam Swift

1996 [1992] Liberals \& Communitarians. Cambridge: Blackwell Publishers.

Münzel, Mark

2007

“'Identidad étnica” - Una mala palabra bárbara de los años 90 y esperanzas para el pluralismo. Algunos pensamientos sobre la globalización de la ideología volk'. En: Wiltrud Dresler, Bernd Fahmel y Karoline Noack, eds., Culturas en movimiento. Contribuciones a la transformación de identidades étnicas y culturas en América, pp. 327-344. 
México: Universidad Nacional Autónoma de México/ IberoAmerikanisches Institut Preussischer Kulturbesitz.

Myerhoff, Barbara

1986 “Life Not Death in Venice?: Its Second Life”. En: Victor Turner y Edward Bruner, eds., The Anthropology of Exprerience, Urbana y Chicago: University of Illinois Press.

Mignolo, Walter

2011

"El pensamiento decolonial, desprendimiento y apertura". En: Enrique Dussel, Eduardo Mendieta y Carmen Bohórquez, eds., El pensamiento filosófico latinoamericano, del Caribe y 'latino' (1300-2000): historia, corrientes, temas y filósofos, pp. 659-672. México: Siglo XXI.

Morey, Miguel

1990

"Introducción: la cuestión del método". En: Michel Foucault, Tecnologías del yo y otros textos afines, pp. 9-43. Barcelona: Paidós.

Negroe Sierra, Genny

1990

"Identidad social en Chuburná". En: Boletín de la Escuela de Ciencias Antropológicas, vol. 16, núm. 101, pp. 5-19.

Novelo Montejo, Yazmín Y.

2011

"Lengua maya amenazada". En: Reporteros Hoy, 19 de mayo del 2011.

Disponible en línea: <http://www.reporteroshoy.mx/wp/lengua-mayaamenazada.html>

Okoshi, Tsubasa 2001

"Mito, historia y legitimación del poder entre los mayas posclásicos de Yucatán”. En: Ruth Gubler, comp., Yucatán a través de los siglos, 213228. Mérida: Universidad Autónoma de Yucatán. 
Ong, Aihwa

Neoliberalism as exception. Mutations in citizenship and sovereignty. Durham/Londres: Duke University Press.

Ortner, Sherry B.

1984

"Theory in Anthropology since the Sixties". En: Comparative Studies in Society and History, vol. 26, núm. 1, pp. 126-166

2006 Anthropology and Social Theory. Culture, Power and the Acting Subject. Durham: Duke University Press.

Pérez Luna, Julio Alfonso 2002

"John Lloyd Stephens. Los indígenas y la sociedad mexicana en su obra". En: Manuel Ferrer Muñoz, ed., La imagen del México decimonónico de los visitantes extranjeros: ¿un estado-nación o un mosaico plurinacional?, pp. 195-216. México: Instituto de Investigaciones Jurídicas-Universidad Nacional Autónoma de México.

Pérez Ruiz, Maya Lorena

2011 "Retos para la investigación de los jóvenes indígenas". En: Alteridades, vol. 21, núm. 42, pp. 65-75.

2011 b "Ser joven entre los mayas de Yucatán. Diferencia y desigualdad en la globalización”. En: Sociedad y Discurso, núm. 20, pp. 79-102.

Piketty, Thomas

2014 El capital en el siglo XXI. México: Fondo de Cultura Económica.

Pitarch, Pedro

“El imaginario prehispánico”. En: Nexos, vol. 29, núm. 359, pp. 49-54.

Poot Capetillo, Efraín Eric 
De partido opositor a opción de gobierno. Orígenes y consolidación del Partido Acción Nacional como alternativa electoral en la ciudad de Mérida: 1960-1995. Mérida: Universidad Autónoma de Yucatán.

Postill, John 2008

"Localizing the Internet Beyond Communities and Networks". New Media Society 10(3):413-431.

Quezada, Sergio

Pueblos y caciques yucatecos, 1550-1580. México: El Colegio de México. 2001 Breve historia de Yucatán. México: Fondo de Cultura Económica.

Quijano, Aníbal

"Colonialidad del poder, eurocentrismo y América Latina". En: Edgardo Lander, comp., La colonialidad del saber: eurocentrismo y ciencias sociales. Perspectivas latinoamericanas, pp. 201-246. Buenos Aires: Consejo Latinoamericano de Ciencias Sociales.

Quintal Avilés, Ella Fanny

2002 "Introducción a Antropología de los mayas de la península de Yucatán". En: Las regiones indígenas en el espejo bibliográfico, tomo 1, pp. 225231. México: Instituto Nacional de Antropología e Historia.

2005 "Way yano'one: aquí estamos. La fuerza silenciosa de los mayas excluidos". En: Miguel A. Bartolomé, Visiones de la diversidad: relaciones interétnicas e identidades indígenas en el México actual, pp. 291-371. México: Instituto Nacional de Antropología e Historia.

Quintal Avilés, Ella Fanny et al.

"Solares, rumbos y pueblos. Organización social de los mayas peninsulares". En: S. Millán y J. Valle, eds., La comunidad sin límites: estructura social y organización comunitaria en las regiones indigenas de 
México, vol. 1, pp. 292-399. México: Instituto Nacional de Antropología e Historia.

Rabinow, Paul

Marking Time: On the Anthropology of the Contemporary. Princeton: Princeton University Press.

Radcliffe-Brown, A. R.

1974 [1952] Estructura y función en la sociedad primitiva. Barcelona: Península.

Ramírez Carrillo, Luis Alfonso

2002

"Yucatán". En: Mario Humberto Ruz, coord.., Los mayas peninsulares: un perfil socioeconómico, pp. 47-77. México: Universidad Nacional Autónoma de México.

2015

Pobres pero globales. Desarrollo y desigualdad social en el sureste de México. México: Miguel Ángel Porrúa/Universidad Autónoma de Yucatán.

Recondo, David

2007 La política del gatopardo. Multiculturalismo y democracia en Oaxaca. México: Centro de Investigaciones y Estudios Superiores en Antropología Social/Centro de Estudios Mexicanos y Centroamericanos.

Redfield, Robert

"Sociological Study YB 32:100-104, 1933". En Carnegie Reports. Washington: Carnegie Institution of Washington.

The Folk Culture of Yucatan. Chicago: University of Chicago Press.

1944 [1941] Yucatán: una cultura en transición. México: Fondo de Cultura Económica.

$1950 \quad A$ village that chose progress: Chan Kom revisited. Chicago: University of Chicago Press. 
Redfield, Robert y Alfonson Villa Rojas

1934 Chan Kom. A Maya village. Carnegie Institution of Washington.

Redfield, Robert, Ralph Linton y Melville Herskovits 1936 "Memorandum for the study of acculturation". En: American Anthropologist, vol. 38, núm. 1, pp. 149-152.

Reed, Nelson

1964 The Caste War of Yucatán. Palo Alto: Stanford University Press.

Restall, Matthew

1995 “'He wished it in vain”: subordination and resistance among Maya women in Post-Conquest Yucatan”. En: Ethnohistory, vol. 42, núm. 4, pp. 577494.

1997 The Maya World: Yucatec culture and society, 1550-1850. Stanford: Stanford University Press.

Reygadas, Luis 2007

"La desigualdad después del (multi) culturalismo". En: Angela Giglia, Carlos Garma y Ana Paula de Teresa, comps., ¿Adónde va la antropología? pp. 341-364. México: Universidad Autónoma Metropolitana/Juan Pablos.

2008 La apropiación. Destejiendo las redes de la desigualdad. Barcelona: Anthropos/Universidad Autónoma Metropolitana.

2009 “Equidad intercultural”. En: Miguel Ángel Aguilar, Eduardo Nivón, María Ana Portal, Rosalía Winocur, coords., Pensar lo contemporáneo: de la cultura situada a la convergencia tecnológica, pp. 67-84. Barcelona: Anthropos/Universidad Autónoma Metropolitana-Iztapalapa.

Ribeiro, Gustavo Lins 
Postimperialismo. Cultura y política en el mundo contemporáneo. Barcelona: Gedisa.

Ribeiro, Gustavo Lins y Arturo Escobar

eds., World Anthropologies. Disciplinary Transformations Within Systems of Power. Oxford: Berg.

Richards, Patricia

2004

Pobladoras, indigenas, and the State. Conflicts over women's rights in Chile. Nueva Jersey: Rutgers University Press.

Rosales González, Margarita and Genner Llanez Ortiz 2003 "La Defensa y la Transformación de un Legado. Organizaciones Indígenas en la Peninsula de Yucatán." In Los Investigadores de la Cultura Maya 11, vol. 2. Campeche: Universidad Autónoma de Campeche, 549-562.

Rugeley, Terry

1996 Yucatán's Maya Peasantry and the Origins of the Caste War. Austin: University of Texas Press.

Said, Edward

2004 [1978] Orientalismo. México: Debolsillo.

Salgado Borge, Antonio

2013 “Festival de la Cultura Maya?”. En: Diario de Yucatán, 13 de octubre. URL: <http:/yucatan.com.mx/editoriales/festival-de-la-cultura-maya>

Sand, Shlomo

2011 La invención del pueblo judio. Madrid: Akal. 
Santos, Boaventura de Sousa

Renovar la teoría crítica y reinventar la emancipación social (encuentros en Buenos Aires). Buenos Aires: Consejo Latinoamericano de Ciencias Sociales.

2009

Una epistemología del sur: la reinvención del conocimiento y la emancipación social. Buenos Aires: Consejo Latinoamericano de Ciencias Sociales/Siglo XXI.

Sariego Rodríguez, Juan Luis

2002

El indigenismo en la Tarahumara. Identidad, comunidad, relaciones interétnicas y desarrollo en la Sierra de chihuahua. México: INI/CONACULTA/INAH.

2007

"La academización de la antropología en México", en Angela Giglia, Carlos Garma y Ana Paula de Teresa (eds.), ¿Adónde va la antropología?, México, Universidad Autónoma Metropolitana-Iztapalapa, pp. 111-127.

Sarmiento Silva, Sergio

1985

"El Consejo Nacional de Pueblos Indígenas y la política indigenista". En: Revista Mexicana de Sociología, vol. 47, núm. 3, pp. 197-215.

Sassen, Saskia

2011

"The Global Street Comes to Wall Street". En: Possible Futures. Revista en línea, obtenido de <http://www.possible-futures.org/2011/11/22/theglobal-street-comes-to-wall-street/>

Scott, James

$2000 \quad$ Los dominados y el arte de la resistencia. Discursos ocultos. México: Era.

Sieder, Rachel y Jessica Witchell

2001 "Advancing indigenous claims through the law: Reflections on the Guatemalan Peace Process". En: Jane Cowan, Marie Dembour y Richard 
Wilson, eds., Culture and Rights, pp. 201-225. Cambridge/Nueva York: Cambridge University Press.

\section{Sierra, María Teresa}

"Desafíos al Estado desde los márgenes: justicia y seguridad en la experiencia de la policía comunitaria de Guerrero". En: María Teresa Sierra, Rosalva Aída Hernández y Rachel Sieder, eds., Justicias indígenas y Estado: violencias contemporáneas, pp. 159-193. México: Facultad Latinoamericana de Ciencias Sociales/Centro de Investigaciones y Estudios Superiores en Antropología Social.

Sierra, María Teresa, Rosalva Aída Hernández y Rachel Sieder

"Introducción". En: María Teresa Sierra, , Rosalva Aída Hernández y Rachel Sieder, eds. Justicias indígenas y Estado: violencias contemporáneas, pp. 13-47. México: Facultad Latinoamericana de Ciencias Sociales/Centro de Investigaciones y Estudios Superiores en Antropología Social.

Sierra O'Reilly, Justo

1994 [1858] Los indios de Yucatán. Consideraciones históricas sobre la influencia del elemento indígena en la organización social del país. Mérida: Universidad Autónoma de Yucatán.

Speed, Shannon

2006 "Entre la antropología y los derechos humanos. Hacia una investigación activista y comprometida críticamente". En: Alteridades, vol. 16, núm. 31, pp. 73-85.

Spivak, Gayatri

2003 [1985] “¿Puede hablar el subalterno?”. En: Revista Colombiana de Antropología, vol. 39, pp. 297-364. 
Starn, Orin

2011

"Here comes the anthros (again): the strange marriage of Anthropology and native America", Cultural Anthropology, vol. 26, núm. 2, pp. 179204.

Stephens, John Lloyd

1969 [1841] Incidents of travel in Central America, Chiapas and Yucatán. Vol. II. Nueva York: Dover.

2003 [1873] Viaje a Yucatán 1841-1842. México: Fondo de Cultura Económica. Trad. de Justo Sierra O'Reilly.

Steward, Julian

1973 Theory of culture change. Chicago: University of Illinois Press.

Strickson, Arnold

1965 "Hacienda and plantation in Yucatán. A historical-ecological consideration of the Folk-Urban Continuum". En: América Indigena, vol. 25 , núm. 1.

Sullivan, Paul

1991 [1989] Conversaciones inconclusas. Mayas y extranjeros entre dos guerras. Barcelona: Gedisa.

Suzuki, Motoi 2006

“Cómo apreciar las organizaciones mayas en Yucatán? Un dilema para la antropología del desarrollo". En: Kazuyasu Ochiaai, coord., El mundo maya: miradas japonesas, pp. 211-223. Mérida: Universidad Nacional Autónoma de México.

Taracena Arriola, Arturo 
"La civilización maya y sus herederos. Un debate negacionista en la historiografía moderna guatemalteca". En: Estudios de Cultura Maya, vol. 27, pp. 43-55.

De la nostalgia por la memoria a la memoria nostálgica. La prensa literaria y la construcción del regionalismo yucateco en el siglo XIX. México: Universidad Nacional Autónoma de México.

Taracena Arriola, Arturo y Adam T. Sellen

2006

"Emanuel von Friedrichsthal: su viaje a América y el debate sobre el origen de la civilización maya". En: Península, vol. 1, núm. 2, pp. 49-79.

Taylor, Charles

2009 [1992] El multiculturalismo y la "política del reconocimiento”. México: Fondo de Cultura Económica.

Taylor, Diana

2003 The Archive and the Repertoire. Performing Cultural Memory in the Americas. Duke University Press.

Thompson, Richard

1974 Aires de progreso. Cambio social en un pueblo maya de Yucatán. México: Instituto Nacional Indigenista.

Toledo Llancaqueo, Víctor

2005 "Políticas indígenas y derechos territoriales en América Latina: 19902004. ¿Las fronteras indígenas de la globalización?”. En: Pablo Dávalos, comp., Pueblos indígenas, Estado y democracia, pp. 67-102. Buenos Aires: Consejo Latinoamericano de Ciencias Sociales.

Tomlins, Christopher y John Comaroff 

Review, vol. 1, núm. 3, pp. 1039-1079.

Torres, Gabriela

"La fuerza del etnoargumento y las preguntas no planteadas cuando estudiamos las relaciones de propiedad en regiones indígenas del México contemporáneo". Ponencia presentada en el III Congreso Mexicano de Antropología Social y Etnología. Centro Cultural del México Contemporáneo/Palacio de la Inquisición, Ciudad de México, 24-26 de septiembre de 2014.

Trouillot, Michel-Rolph

2011 [2003] Transformaciones globales. La antropología y el mundo contemporáneo. Popayán/Bogotá: Universidad del Cauca/CESO-Universidad de los Andes.

Tsing, Anna 2005

Friction: An Ethnography of Global Connection. Princeton: Princeton University Press.

Turner, Terence

1993 "Anthropology and multiculturalism: what is Anthropology that Multiculturalists should be mindful of it?". En: Cultural Anthropology, vol. 8, núm. 4, pp. 411-429.

Turner, Victor

1974 "Hidalgo: History as Social Drama". En: Dramas, Fields and Metaphors. Symbolic Action in Human Society, pp. 98-155. Ithaca y Londres: Cornell University Press.

Urías Horcasitas, Beatriz

2008 "El poder de los símbolos/los símbolos en el poder: teosofía y 
‘mayanismo’ en Yucatán (1922-1923)’. En: Relaciones, vol. 29, núm. 115, pp. 179-212.

Urteaga, Maritza

2011 La construcción juvenil de la realidad. Jóvenes mexicanos contemporáneos. México: Universidad Autónoma Metropolitana/Juan Pablos.

Valladares, Laura, coord.

2014 Nuevas violencias en América Latina. Los derechos indígenas ante las políticas neoextractivistas y las políticas de seguridad. México: UAM/Juan Pablos.

Varela, Roberto

2006 [1984] Expansión de sistemas y relaciones de poder. Antropología política del Estado de Morelos. México: Universidad Autónoma Metropolitana.

Vázquez León, Luis

1992 Ser indio otra vez. La purepechización de los tarascos serranos. México: Consejo Nacional para la Cultura y las Artes.

2010 Multitud y distopía. Ensayos sobre la nueva condición étnica en Michoacán. México: Universidad Nacional Autónoma de MéxicoPrograma México Nación Multicultural.

Villanueva Villanueva, Nancy

2008 "La revaloración de la cultura maya en Yucatán”. En: Temas Antropológicos, vol. 30, núm. 2, pp. 79-108.

Villoro, Luis

1979 [1949] Los grandes momentos del indigenismo en México. México: Centro de Investigaciones Superiores del Instituto Nacional de Antropología e 
Historia.

Viveiros de Castro, Eduardo

2010 [2009] Metafisicas caníbales. Líneas de antropología postestructural. Buenos Aires: Katz.

Von Hagen, Victor Wolfgang

1947 Explorador maya. John Lloyd Stephens y las ciudades perdidas de América Central y Yucatán. Buenos Aires: Librería Hachette S.A.

Wade, Peter, Ed.

$2000 \quad$ The right to difference is a fundamental human right. Manchester: Group for Debates in Anthropological Theory.

Warman, Arturo et al.

1970 De eso que llaman antropología mexicana. México, Comité de Publicaciones de los alumnos de la Escuela Nacional de Antropología e Historia.

Wallerstein, Immanuel

2015 "El multiculturalismo y sus dilemas". En: La Jornada, 22 de febrero de 2015.

Warren, Kay B.

1998 Indigenous movements and their critics: pan-Maya activism in

Guatemala. Princeton University Press.

Weber, Max

2003. [1904-1905] La ética protestante y el espíritu del capitalismo. México: Fondo de Cultura Económica.

2006 “La 'objetividad' cognoscitiva de la ciencia social y de la política social”. 
En: Ensayos sobre metodología sociológica, pp. 39-101. Buenos Aires:

Amorrortu.

2014 Economía y sociedad. México: Fondo de Cultura Económica (ed. revisada, comentada y anotada por Francisco Gil Villegas M.).

Willey, Gordon R. y Jeremy A. Sabloff

1974 A History of American Archaeology. Londres: Thames and Hudson.

Wisniewski, Maciek

2015 "El campo, el capitalismo y la ideología”. En: La Jornada, 27 de febrero de 2015.

Wolf, Eric R.

1956 "Aspects of group relations in a complex society: Mexico". En: American Anthropologist, vol. 58, núm. 6, pp. 1065-1078.

2001 [1998] Figurar el poder. Ideologías de dominación y crisis. México: Centro de Investigaciones y Estudios Superiores en Antropología Social.

2005 [1982] Europa y la gente sin historia. México: Fondo de Cultura Económica.

2011 [1990] "Revestir el poder: viejas ideas, nuevas cuestiones”. En: Metapolítica, vol. 15, núm. 75, pp. 77-86.

Young, Iris Marion

1989 "Polity and group difference: A critique of the ideal of universal citizenship". En: Ethics, vol. 99, núm. 2, pp. 250-274.

Zapf, Harald

"Ethnicity and Performance: Bilingualism in Spanglish Verse Culture". En: Amerikastudien/American Studies, vol. 51, núm. 1, pp. 13-27. 